UNIVERSIDADE DE SÃO PAULO

ESCOLA DE COMUNICAÇÕES E ARTES

PROGRAMA DE PÓS-GRADUAÇÃO EM CIÊNCIA DA INFORMAÇÃO

BIANCA MARIA SANTANA DE BRITO

A escrita de si de mulheres negras:

memória e resistência ao racismo 


\title{
A escrita de si de mulheres negras: memória e resistência ao racismo
}

\author{
Versão Corrigida
}

Tese apresentada ao Programa de Pós-Graduação em Ciência da Informação da Escola de Comunicações e Artes da Universidade de São Paulo, para obtenção do título de Doutora em Ciências sob a orientação do Prof. Dr. Marco Antonio de Almeida. 
Autorizo a reprodução e divulgação total ou parcial deste trabalho, por qualquer meio convencional ou eletrônico, para fins de estudo e pesquisa, desde que citada a fonte.

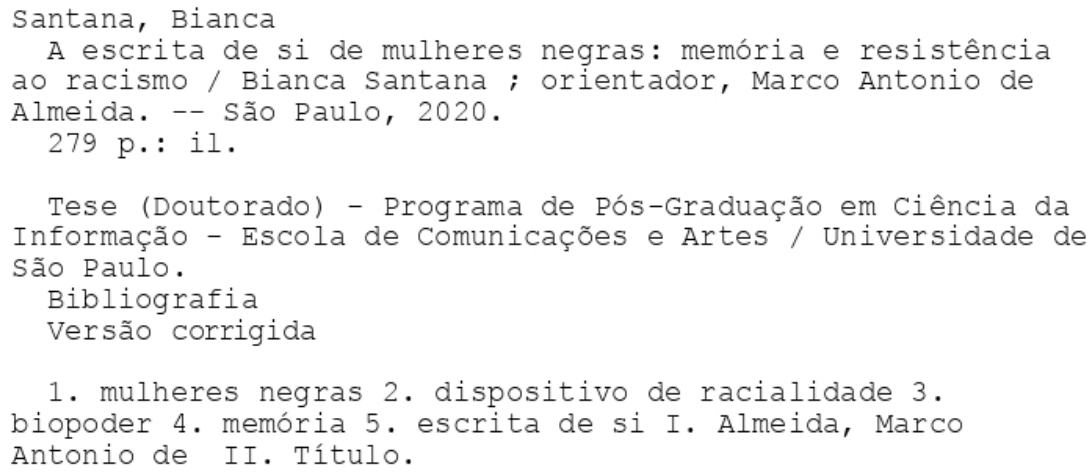

CDD 21.ed. - 020 
Nome: SANTANA, Bianca

Título: A escrita de si de mulheres negras: memória e resistência ao racismo.

Tese apresentada ao Programa de Pós-Graduação em Ciência da Informação da Escola de Comunicações e Artes da Universidade de São Paulo, para obtenção do título de Doutora em Ciências.

Aprovada em:

Banca Examinadora

Prof. Dr.

Instituição:

Julgamento:

Profa. Dra.

Instituição:

Julgamento:

Profa. Dra.

Instituição:

Julgamento:

Profa. Dra.

Instituição:

Julgamento:

Profa. Dra.

Instituição:

Julgamento: 
Dedico este trabalho à minha mãe, Maria de Jesus Pereira Santana, que, de empregada doméstica a bacharel em economia, dedicou a vida à sobrevivência das suas e dos seus, rompendo com a subordinação e a subalternização a cada frase enérgica ou gargalhada, avolumando as águas da insurgência. 


\section{AGRADECIMENTOS}

A Marco Antonio Almeida, pela orientação essencial a este trabalho, sempre respeitosa, acolhedora e presente.

Aos colegas do PRACTIC - Grupo de Estudos de Práticas Culturais e Tecnologias de Informação e Comunicação.

A Giulia Crippa e Giovanna Xavier, pelos comentários tão pertinentes na banca de qualificação e na avaliação final desta tese.

A Maria Aparecida Moura e Gabriela Leandro Pereira (Gaia), pelas contribuições na avaliação final desta tese.

A Giulia Crippa e Lucia Maciel Barbosa de Oliveira, pelas disciplinas cursadas, inspiração acadêmica, comentários em seminários de pesquisa e encontros informais.

À professora Ecléa Bosi (in memorian) por tanto aprendizado na última turma do curso "Cultura e Memória Social: a História Oral".

À professora Márcia Lima e aos colegas do grupo de estudos "Raça, desigualdade e política".

Às colegas Thaís Pereira, Fernanda Ferreira da Silva, Thulio Gomes, Toni William, Fernanda Fragoso Zanelli, Bernardo Galegale, Carina Shimizu, Carolina Ito, Mariana Xis e Eduardo Sena.

A Gabriela Leandro Pereira (Gaia) pela interlocução sempre preciosa e indicações precisas.

A Juliana Gonçalves, Cinthia Abreu, Cinthia Gomes, Mara Minassian, Maria José Menezes, Neon Cunha, Marli Aguiar e toda a Marcha das Mulheres Negras, que me permitiram, no julho das pretas, divulgar e oferecer a oficina cujos textos são analisados neste trabalho.

A Daysi Bregantini e Fernanda Paola, pelo incentivo constante e ao Espaço Cult por acolher a oficina de escrita cujos textos são analisados neste trabalho.

A Chris Gomes, companheira de sonhos, projetos, aventuras e toda a equipe da Fundação Rosa Luxemburgo.

A José do Carmo Araújo, Ivana Parrela, Jean Camoleze, Fernanda Carneiro e Helder Carneiro pelas aulas sobre Minas Gerais e arquivologia.

A Joana Andrade, Norma Haru e Adriane Freitag, pelo apoio à pesquisa na Biblioteca Mário de Andrade.

A quem abriu as portas, a agenda e flexibilizou prazos para a consulta de documentos históricos: Carmen Regina Gervone, professora da Escola Guilherme Kuhlmann; Pergeane Sheila, da Paróquia São Sebastião, de Rodeiro (MG); Igor, da Paróquia São Januário, de 
Ubá (MG); Marta, da Paróquia Sant'Anna, de Guidoval (MG); Nair Pascoal, do Arquivo Histórico de Ubá; Michele Silva, Josiane Coelho e Renato David, do cartório de Ubá Adjalmo, do cartório de Rodeiro; Michele e Ruth, do cartório de Guidoval.

A Suelaine e Solimar Carneiro, Nilza Iraci, Sonia Maria Nascimento, Maria Sylvia Oliveira, Inês Castilho, Maria Lucia da Silveira, Tica Moreno, Matilde Ribeiro, Thania Pereira Teixeira de Carvalho Cardin, André Augusto Beleza, Marcos José Vicente de Azevedo pelas respostas a infinitas dúvidas de pesquisa.

A Dalva Santos, Ester Rizzi, Mariana Belmont, Valerya Borges pelas leituras e comentários à escrita desta tese.

A Tatiana Mohr, pela revisão cuidadosa.

A Vanessa Nascimento, Mariana Belmont, Douglas Belchior, Beatriz Lourenço, Luana Vieira, Thais Santos Silva, Fabiola de Carvalho Pereira, Catia Cipriano, Thiago Fernandes, Thiago Rubens, Fabiola Ramos, Patricia Firmino, Tomaz Amorim, Wellington Lopes, Jéssica Santos Ferreira, Caio Chagas e toda a companheirada da Uneafro, pela paciência, espera e apoio.

À Coalizão Negra por Direitos, nas figuras de Nilma Bentes, Sheila de Carvalho, Selma Dealdina, Anielle Franco, Antonio Francisco, Regina Adami, Edson Cardoso, Maria Sylvia Oliveira, Zezé Menezes, Vilma Reis, Zélia Amador, Maria Clara D’Avilla, Monica Oliveira, Vanda Menezes, Wania Sant'anna, Lucia Xavier, Biatriz Santos, Flavinha Tambor, Mariana Belmont, Douglas Belchior, Pedro Borges, Edson França, Nuno Leal, Wagner Moreira, pela caminhada conjunta e paciência nos momentos de ausência.

Às mestras e companheiras do Ilú Obá de Min, especialmente Beth Beli, Nega Duda, Mazé Cintra, Teresa Teles, Wanda Martins, Baby Amorim, Cris Blue, Chris Gomes, Monica Godinho, Adriana Quedas, Valerya Borges e todas as alfaias, naipe que não faia.

À Tia Guida, por nomear o invisível e partilhar sabedoria.

A Pedro Carvalho, Soledad Maria, Selma e Walter Canoas, Josiane Zarouk, Catia Cipriano, Bruna Silveira, Debora Pivotto e Maurice Jacoel, pelos cuidados terapêuticos e amizade.

A Cidinha da Silva, Daniela Silva, Lia Rangel, Rodrigo Savazoni, Sandra Silva, Aline Godoy Vieira, Tica Moreno, Débora Pivotto, Marina Terra, Gustavo Anitelli, Itamar e Thania Cardin, Paulo Darcie, Ana Luiza, Raphael Prado, Marcella Chartier, Georgia Nicolau, pelo incentivo, interlocução, amizade, ajuda com as crianças.

À comadre Maitê Freitas, pela paciência com meus sumiços, presença amorosa e pela Ilundy Airá.

A Glaucia Colesbrusco, Josiane Zarouk, Luciana César Guimarães, André Augusto Bezerra, Daniel de Bonis, Marcos José Vicente de Azevedo, por nossa aldeia de partilhar a vida e cuidar das crianças.

A Silvia Chiarelli e à equipe da escola Alecrim, a Teca Soub e à equipe da Ateliescola Acaia, pela educação, cuidado e apoio às crianças de mãe ausente. 
À vizinhança pela partilha dos cuidados e transporte das crianças, especialmente Renato, Raquel, João, Rafaela, Daniel, Rogerio, Daniela, Sandra, Lu, Glauco, Ruchelle, Rodrigo, Mariana, Sylvia, Priscila, Marcelo, Ana Paula, Marcia.

A Julia Codo, pelo quarto silencioso, tapiocas e frutas que nutriram o foco da escrita.

A Maria Lúcia e Maria José da Silveira, Stella Bruna Santo, André Senna, Caio Franco, por serem família.

A Bruninha, pelas trocas constantes, ajuda com as crianças, elogios exagerados e pelo Camilo.

A Lucas, Pedro e Cecília, por respeitarem tantas horas da mamãe no computador e pela sutileza em não me deixar dispersar: "desse jeito você não vai acabar nunca!".

A minha mãe, Maria de Jesus Pereira Santana, por ter priorizado o investimento na minha educação ao longo de toda a vida, pelo apoio constante e incondicional, pelos cuidados das crianças, pelas leituras, broncas, perguntas e comentários.

A Sergio Amadeu da Silveira, meu amor, companheiro, interlocutor, com quem divido sonhos, trabalho doméstico, cuidado das crianças, por ter segurado a onda sozinho em diversos momentos desta escrita, pelas críticas, sugestões e incentivo constante.

A Taata Mutá Imê, pelo cuidado espiritual e por mostrar caminho.

A Sueli Carneiro, pelas entrevistas, conselhos, broncas, orientações, acolhida e tanto ensinamento.

À Coordenação de Aperfeiçoamento de Pessoal de Nível Superior - Brasil (CAPES), pela bolsa de pesquisa que possibilitou a realização deste trabalho. 
"Falarei do lugar da escrava. (...) é preciso explicitarte a identidade de quem te fala, sem tergiversações. Não são definições minhas, mas as adoto por estar com elas de acordo e pela certeza de facilitar tua compreensão. Como já te adiantei, sou negra, uma juntada de pretos e pardos. Ora, não me peças explicações sobre coisas que tu inventaste como esse 'pardo'. Só sei que a cada dia que passa, ele fica mais negro”.

(Sueli Carneiro, na introdução de sua tese de doutorado, de 2005) 


\section{RESUMO}

SANTANA, Bianca. A escrita de si de mulheres negras: memória e resistência ao racismo. Tese (Doutorado) - Escola de Comunicações e Artes da Universidade de São Paulo, São Paulo, 2020.

A hipótese deste trabalho é que a escrita de mulheres negras, de formulação estética de sua própria existência e trabalho de memória, possibilita a constituição de subjetividades e de sujeitos coletivos que permitem resistir ao racismo. A partir de reflexões acerca das formulações de Sueli Carneiro sobre dispositivo de racialidade, biopoder, epistemicidio e resistência, foram reunidos textos aqui categorizados como clássicos ou táticos. Fragmentos destes textos foram interpretados à luz de teorias da memória, arquivos, organização política de mulheres negras, resistência e também de informações do contexto em que a escrita se realizou, divididos em sete eixos: sobrevivência física, preservação da saúde e da capacidade cognitiva; elaboração de traumas; organização de sujeitos coletivos; crítica aos processos de exclusão racial, social e de gênero; ruptura com a subordinação e a subalternização aos discursos de dominação racial, de gênero e social; olhar a partir de uma perspectiva própria; proposição de caminhos de emancipação individual e coletiva. A conclusão é de que a escrita de si de mulheres negras é um instrumento de produção e circulação de informação e conhecimento, técnica de pesquisa e tecnologia individual e coletiva de resistência ao racismo.

Palavras-chave: mulheres negras; dispositivo de racialidade; biopoder; memória; escrita de si. 


\begin{abstract}
SANTANA, Bianca. Black women's writing of the self: memory and resistance against racism. Dissertation (doctoral) - Escola de Comunicações e Artes da Universidade de São Paulo, São Paulo, 2020.

The hypothesis of this work is that black women's writing, with an aesthetic formulation of their own existence and memory work, allows the constitution of subjectivities and collective subjects that allow them to resist racism. Based on reflections about Sueli Carneiro's formulations on the dispositif of raciality, biopower, epistemicide and resistance, texts were categorized as classic or tactical. Fragments of these texts were interpreted in the light of theories of memory, archives, political organization of black women, resistance and also information on the context in which writing took place, divided into seven axes: physical survival, preservation of health and cognitive ability; elaboration of traumas; organization of collective subjects; criticism of racial, social and gender exclusion processes; break with subordination and subordination to discourses of racial, gender and social domination; look from an own perspective; proposition of individual and collective paths of emancipation. The conclusion is that black women's writing of the self is an instrument for the production and circulation of information and knowledge, research technique and individual and collective technology to resist racism.
\end{abstract}

Keywords: black women; dispositif of raciality; biopower; memory; writing of the self. 


\section{LISTA DE ABREVIATURAS E SIGLAS}

AFRO/Cebrap - Núcleo de Pesquisa e Formação em Raça, Gênero e Justiça Racial do Centro Brasileiro de Análise e Planejamento

Alerj - Assembleia Legislativa do Rio de Janeiro

AMNB - Articulação de Organizações de Mulheres Negras Brasileiras

APNs - Agentes de Pastoral Negros

BRAPCI - Base de Dados em Ciência da Informação

CAPS - Centro de Atenção Psicossocial

CDD - Classificação Decimal de Dewey

Cecan - Centro de Cultura e Arte Negra

CEERT - Centro de Estudos das Relações de Trabalho e Desigualdades

Cedenpa - Centro de Estudo e Defesa do Negro do Pará

COHAB - Companhia Metropolitana de Habitação de São Paulo

CONAQ - Coordenação Nacional de Articulação das Comunidades Negras Rurais Quilombolas

CONEN - Coordenação Nacional de Entidades Negras

FENATRAD - Federação Nacional das Trabalhadoras Domésticas

FEUSP - Faculdade de Educação da Universidade de São Paulo

FFLCH-USP - Faculdade de Filosofia, Letras e Ciências Humanas da Universidade de São Paulo

FLIP - Festa Literária Internacional de Paraty

FNMN - Fórum Nacional de Mulheres Negras

IESP/UERJ - Instituto de Estudos Sociais e Políticos da Universidade do Estado do Rio de Janeiro

MNU - Movimento Negro Unificado

OMS - Organização Mundial da Saúde

ONG - Organização Não Governamental

SEPPIR - Secretaria de Políticas de Promoção da Igualdade Racial

TEN - Teatro Experimental do Negro

UFBA - Universidade Federal da Bahia

UFRJ - Universidade Federal do Rio de Janeiro

UFF - Universidade Federal Fluminense 
UNEGRO - União de Negros pela Igualdade

UNEafro - União de Núcleos de Educação Popular para Negras/os e Classe Trabalhadora

\section{LISTA DE IMAGENS}

Imagem 1: Capa do livro Vozes Insurgentes de Mulheres Negras ....................................25

Imagem 2: Oficina de escrita realizada no "Julho das Pretas", em 2017 .............................30

Imagem 3: Cartaz de divulgação do livro Inovação ancestral de mulheres negras ........... 31

Imagem 4: Diekenga - cosmograma Bakongo .................................................................. 33

Imagem 5: A regente, criadora e diretora do bloco afro Ilú Obá de Min, Beth Beli, no centro do círculo formado por integrantes do bloco, mestras e mestres da cultura popular (de branco) e público, no domingo de carnaval, em 2020

Imagem 6: Nega Duda, cantora e uma das coordenadoras do bloco afro Ilú Obá de Min, abraça Beth Beli ao final do cortejo da sexta feira, no carnaval 2020, em homenagem a Lia de Itamaracá

Imagem 7: O naipe das alfaias em círculo, com a mestra Mazé Cintra e os instrumentos ao centro, em concentração na Praça da República.....

Imagem 8: parte do corpo de dança do bloco-afro Ilú Obá de Min. No centro, de vermelho, Christiane Gomes representa Iansã, em seu lado esquerdo, de roxo, Andréia Alves representa Nanã.

Imagem 9: Taata Mutá Imê, no barracão do Nzó Mutà Lombô ye Kaiongo e a Casa dos

Olhos de Tempo, na parede, representações dos nkisis Kisimbi e Mutalambô. 67

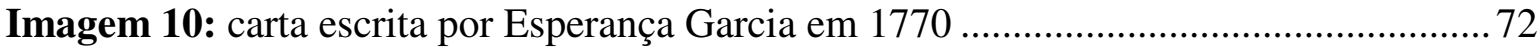

Imagem 11: mapa com as rotas do tráfico negreiro transatlântico para o Brasil ................74

Imagem 12: Informativo sobre o I Encontro Nacional de Mulheres Negras .....................91

Imagem 13: Mais de 50 mil mulheres participam da Marcha das Mulheres Negras ........ 106

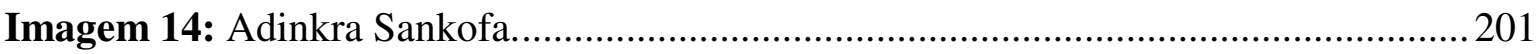

Imagem 15: Militantes da UNEafro Brasil no rio Ribeira, Quilombo Ivaporunduva ....... 212 


\section{LISTA DE QUADROS}

Quadro 1: Temáticas acerca da informação étnico racial ................................................... 42

Quadro 2: tráfico negreiro com destino ao Brasil ................................................................ 73

Quadro 3: Ocupações de libertas na freguesia de Santana - 1849 ..................................... 83

Quadro 4: Quantidade de publicações por autor sobre a temática relacionada ao negro no

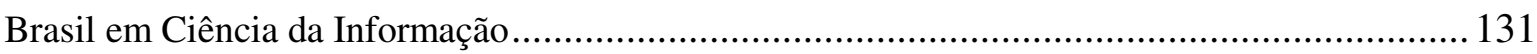




\section{SUMÁRIO}

LAROYÊ!.

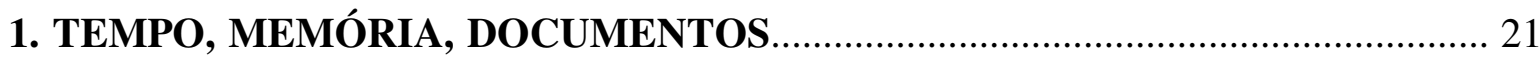

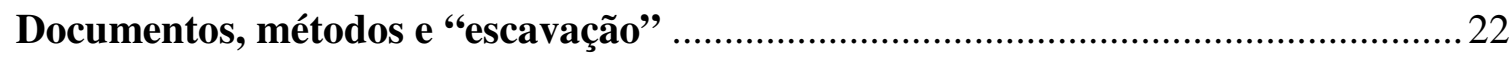

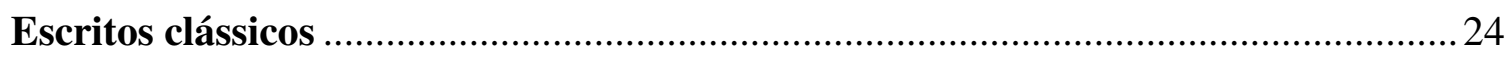

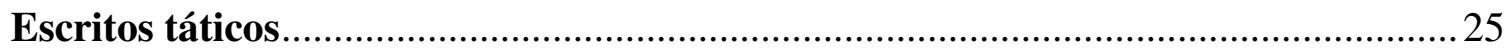

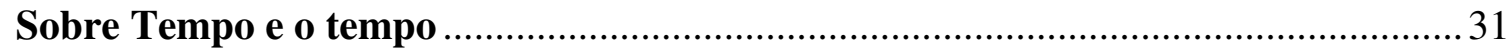

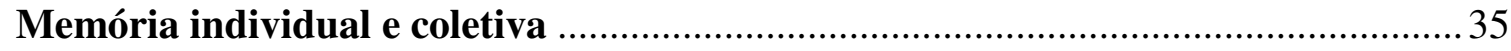

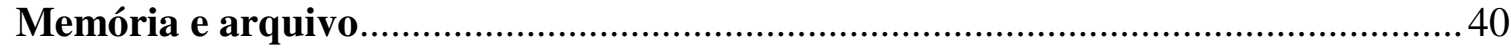

Os documentos de nossos antepassados existem e estão esperando por nós ............. 44

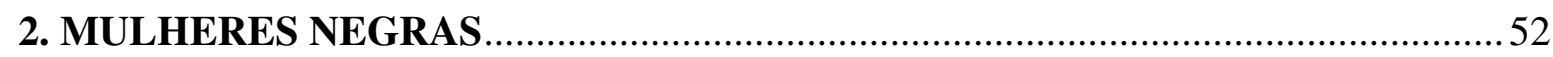

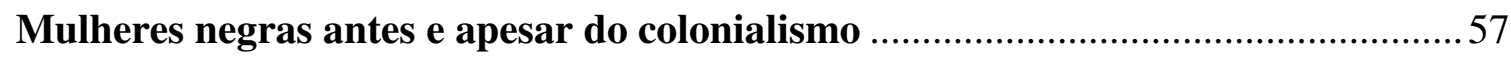

A escravização de mulheres negras no Brasil ........................................................... 70

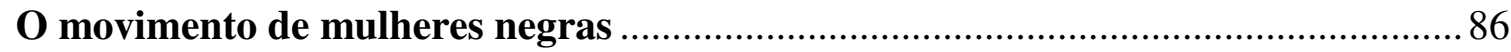

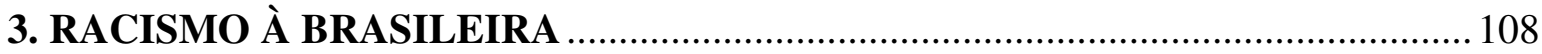

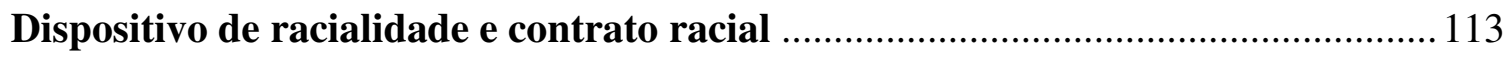

Biopoder, genocídio, necropolítica: sua expressão como epistemicídio ................... 123

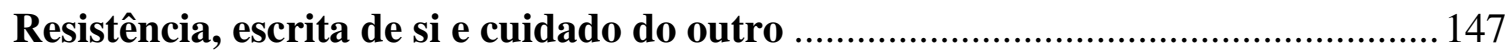

4. A ESCRITA QUE É LUTA, OU A LUTA ESCRITA .......................................... 152

Sobrevivência física, preservação da saúde e da capacidade cognitiva ................... 152

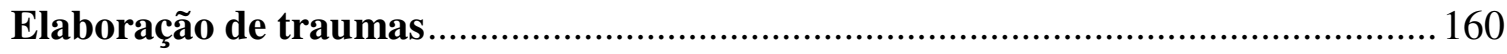

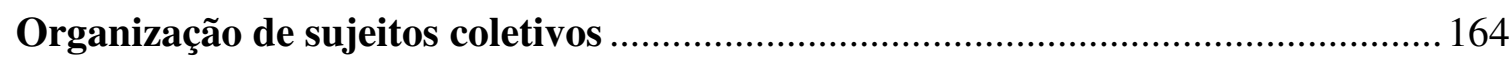

Crítica aos processos de exclusão racial, social e de gênero................................... 173

Ruptura com a subordinação e a subalternização ............................................... 181

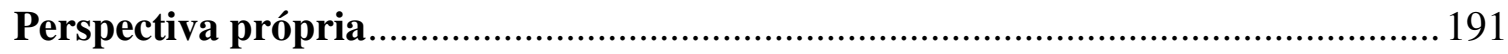

Proposição de caminhos de emancipação individual e coletiva ...............................200

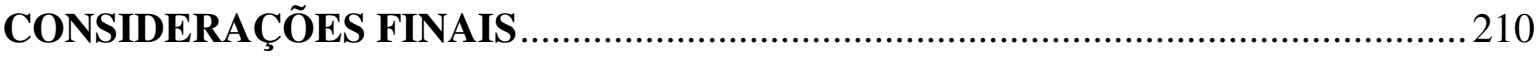


ANEXO 1: Levantamento de escritos de mulheres negras, publicados até 2013, acompanhado de dados históricos de contexto

ANEXO 2: Textos aqui considerados clássicos, publicados na coletânea Vozes Insurgentes de Mulheres Negras: do século XVIII à primeira década do século XXI, acompanhados de breve apresentação de cada autora

ANEXO 3: Relato da primeira oficina de escrita para mulheres negras, realizada em julho de 2017, em São Paulo

ANEXO 4: Fragmentos dos textos produzidos em oficina de escrita para mulheres negras

ANEXO 5: Autoras de Inovação Ancestral de Mulheres Negras: Táticas e Políticas do Cotidiano, com breve apresentação 


\section{LAROYÊ!}

Embarabô agô mojubara, Leba coxê Embarabô agô mojubara, Omode coe co Embarabô agô mojubara, Labara Exu co xê (Cantiga para Exúl)

Exu ајиoта̃ mã qui uô odara

Laroiê Exu иа ји иô mã mã qui uô odara Exu auô Ódara lô xorô ódara lô xorô lona (Cantiga para Exú ${ }^{2}$ )

Sonso obé, Sonso obé Sonso obé, Ódara cô lôri ébo (Cantiga para Exú )

Em 2005, Sueli Carneiro defendeu uma tese de doutorado em que aplicava os conceitos de dispositivo e de biopoder, elaborados por Michel Foucault, ao domínio das relações raciais brasileiras. A partir do estudo de cunho reflexivo especulativo, construiu a noção de dispositivo de racialidade. Da articulação deste dispositivo ao biopoder, que produz e reproduz um sistema de supremacia e subordinação racial, destacou o mecanismo do epistemicídio. E registrou testemunhos de resistência.

A primeira leitura da tese de Sueli Carneiro, feita individualmente, produziu encantamento e a sensação de fichas caindo. A segunda, parcialmente feita de modo coletivo, em um grupo de leitura realizado na sede da UNEAfro na Galeria Metrópole, centro de São Paulo, entre 2018 e a metade de 2019, trouxe novas dimensões de chavesinterpretativas que permitiam a mulheres e homens negros, além de mim, com poucas participações brancas, analisar o hoje de forma densa.

\footnotetext{
1 (Nós acordamos) e cumprimentamos (Esù) Barabô / A vós apresento os meus respeitos. Que não nos façais mal. A criança é ensinada a apresentar seus respeitos à Barabô, ele é o Senhor da Força. Tradução livre, de autoria desconhecida, que recebi de Adriana Quedas. Importante afirmar que tanto a tradução como a pronúncia podem variar de nação para nação de candomblé e até de terreiro para terreiro.

${ }^{2}$ Esù nos olha no culto e nos reconhece, sabendo/ que o culto é bom. Laroiê! Esù nos olha no culto e nos reconhece, sabendo que o culto é bonito./ Vamos cultuar Esù! Tradução livre, de autoria desconhecida, que recebi de Adriana Quedas. Importante afirmar que tanto a tradução como a pronúncia podem variar de nação para nação de candomblé e até de terreiro para terreiro.

${ }^{3}$ Faca pontiaguda, faca pontiaguda, Exú Ódara nãol tem sua cabeça para levar ebó (carrego).Tradução livre, de autoria desconhecida, que recebi de Adriana Quedas. Importante afirmar que tanto a tradução como a pronúncia podem variar de nação para nação de candomblé e até de terreiro para terreiro.
} 
A terceira, costurada por 160 horas de entrevistas com a autora, foi de compreensão mais sofisticada daquilo que provocara tanto encantamento inicial. E assim foi feita a escolha de que a tese de Sueli Carneiro seria a principal referência teórica desta tese de doutorado, e que, portanto, seriam de Sueli Carneiro os ombros de gigante em que me apoio para olhar a escrita e a memória de mulheres negras neste trabalho.

Ainda no início da pesquisa, em 2017, entrevistei Sueli Carneiro para a Revista Cult. Alguns encontros e menos de um ano depois, iniciamos as entrevistas necessárias para que eu escrevesse sua biografia. Alguns episódios da vida de Sueli Carneiro serão, então, apresentados nesta tese como referência que se contrapõe aos paradigmas acadêmicos hegemonicamente brancos.

Em uma conversa com meu orientador, Marco Antonio de Almeida, no jardim da ECA, dias antes da entrevista, ele me incentivou, como sempre incentiva, a conectar o jornalismo à tessitura da tese. Eu ainda não sabia da importância imensa de ter um orientador-parceiro. Nem do quanto as possibilidades de conexão entre atividades aparentemente distantes se aproximariam. Não só entrevistas ou artigos para a Cult, mas tudo o que eu fazia era a tese.

Por quatro anos, me dediquei integralmente à pesquisa do doutorado, o que significa, além das horas de leitura, escrita e pesquisa em campo, a produção de artigos teóricos e jornalísticos, apresentações orais em dezenas de cidades, oficinas de escrita, participação em rodas de conversa, círculos de cuidado e atividades literárias com mulheres negras, alfaia no bloco afro Ilú Obá de Min, organização e publicação de duas coletâneas em livros, participação ativa da articulação da Coalizão Negra por Direitos, escrita da biografia de Sueli Carneiro.

Vivenciar, ler e refletir o ser mulher negra. Escrever, facilitar e analisar a escrita. Escrever para a ação política e agir politicamente pela escrita. Cuidar e ser cuidada em roda, no tambor, na luta. Escavar, ler e registrar a memória. Resistir ao racismo coletivamente. Ser encontradas por ferramentas teóricas que permitissem analisar o que fica aqui nomeado como A escrita de si de mulheres negras: memória e resistência ao racismo.

Durante a FLIP 2019, Ivana Bentes, professora da UFRJ, perguntou se eu entregaria os dois livros publicados naquele ano como anexos da tese, já que eram resultados direto da pesquisa de doutorado. Rimos. E até agora me pergunto se não deveria mesmo fazer isso.

Porque não sei o que é o início desta tese. Só sei qual é o final porque, como escreveu Bruno Latour, é necessário colocar um ponto final. Mas a sensação é de que esta 
pesquisa não acaba. A circularidade, que li e ouvi tantas vezes como um valor civilizatório afro-brasileiro, se materializa nesta certeza, e também em Sueli Carneiro ser a principal referência teórica deste trabalho, e testemunho registrado e analisado, e interlocutora cada vez mais próxima. Circularidade. Mas também axé. Ancestralidade. Com doses de oralidade, ludicidade, cooperativismo, musicalidade, corporeidade, religiosidade, ao investigar a memória. Os dez valores civilizatórios afro-brasileiros sistematizados por Azoilda Loretto da Trindade, em 2010.

Em conexão com tais valores, afirmo que esta é uma tese afro-centrada. A leitura integral do texto permite perceber a circularidade também na forma como temas e nomes aparecem e reaparecem, encadeados de modo não-linear, mas, espero que, com coerência, cadência e sentido. Conforme a cosmologia bacongo, registrada por Tiganá Santos, em sua tese de doutorado recém-apresentada (SANTOS, T., 2019, p. 14), na língua kikongo: "Mono i kadi kia dingo-dingo (kènda-vutusika) kinzungidila ye didi dia ngolo zanzingila. Ngiena, kadi yateka kala ye kalilila ye ngina vutuka kala ye kalulu la", de volta à língua do colonizador: "Eu estou indo-e-voltando-sendo em torno do centro das forças vitais. Eu sou porque fui e re-fui antes, de tal modo que eu serei e re-serei novamente".

Afrocentrada, apesar de apresentada no Brasil, com 54\% de população negra, onde apenas $28,9 \%$ do total de pós-graduandos se auto-declara preto ou pardo; e menos de 3\% dos docentes doutores na pós-graduação de mulheres negras (INEP, 2016, apud Gênero e Número, 2018). Apesar de estar na Universidade de São Paulo, onde apenas 1,83\% dos docentes ativos se auto-declaram negros (USP, 2017). Apesar do rito da ciência moderna inventada na Europa.

As principais referências teóricas são mulheres negras, assim como é de uma maioria de pessoas negras e mulheres os textos citados ao longo da tese. Sobre essa escolha, agradeço à professora Giulia Crippa pela provocação a mim direcionada em um seminário de pós-graduação na ECA: "Em uma pesquisa sobre mulheres negras, como você cita tantos homens brancos?"; e a Jurema Werneck, por um convite geral feito em um seminário no IESP-UERJ: "Por que não citar apenas mulheres? Ou apenas pessoas negras? Se vocês não estão na academia para fazer isso, estão para quê?"

Ouvindo Jurema no auditório repleto de estudantes de pós-graduação, além de poucos docentes e interessados que vinham de fora da universidade, estava Marielle Franco, que havia defendido o mestrado em Administração Pública na UFF, em 2012. Naquele momento, Marielle coordenava a Comissão de Defesa dos Direitos Humanos e Cidadania da Alerj, dedicada a prestar auxílio jurídico e psicológico a familiares de vítimas 
do genocídio negro e também de policiais assassinados. Já construía sua pré-candidatura à vereança do Rio de Janeiro e naquele mesmo ano foi eleita com mais de 46 mil votos.

Depois de exercer um ano e dois meses de mandato, em 14 de março de 2018, Marielle Franco foi executada com quatro tiros na cabeça. Há evidências de que o presidente da república e seus filhos estejam envolvidos com o assassinato. Mas as pistas se embaralham e as cortinas de fumaça são ativadas a cada notícia da investigação que envolve o sobrenome Bolsonaro. Dois anos depois, ainda perguntamos quem mandou matar Marielle. E qual o envolvimento da família Bolsonaro no assassinato de Marielle Franco.

Eu havia finalizado a redação do relatório de qualificação dias antes. E passei um mês, até a banca de qualificação, em 13 de abril de 2018, sem conseguir produzir nada. Uma raiva profundamente dolorosa escorria diariamente pelos meus olhos e de muitas outras mulheres negras com quem convivi para a pesquisa desta tese. E um senso de urgência me tomou de assalto. Jurema Werneck havia perguntado para que estávamos na academia. A partir daquele 14 de março eu estava por justiça. Para lembrar. Para propagar. Reivindicar. Reparar. O desafio era, nisso tudo, ter a leveza para lembrar de também bordar.

Era noite e eu caminhava pelos becos labirínticos de uma favela quando avistei um menino negro no topo de uma escada. Ao subir para tentar encontrá-lo, uma mulher, também negra, me ofereceu ajuda. Apontou a fronteira perigosa com a estrada, uma curva onde passavam muitos carros, e me levou até um quintal de terra batida, bem no alto.

No terreiro, havia uma árvore frondosa, aroma de grama cortada, ervas plantadas nos cantos e uma mulher toda de branco, de turbante, sentada em uma pedra. Ela tinha um livro nas mãos: grande, com a capa de tecido colorido e letras bordadas no miolo. As páginas tinham cheiro de lavanda. A folha de rosto era uma espécie de envelope e guardava pedras, folhas secas. E a lua crescente.

Maravilhada, formulei na cabeça a pergunta, mas, antes que chegasse à boca, acordei. Escrevi no caderno de cabeceira, em uma manhã de 2017: "Como faz para bordar uma tese?" Três anos depois, sinto que bordei palavras com perfume de manjericão, toques de coco e proteção de peregum.

$\mathrm{Na}$ primeira parte, "Tempo, memória, documentos" são apresentadas reflexões sobre o tempo, em uma abordagem afro-centrada, e o nkisi banto Tempo. E então desenrolo o fio da memória, articulando Fu-Kiau, Ecléa Bosi, Jeanne Marie Gagnebin, Grana Kilomba e a norte-americana Jenny Sharpe. Ao relatar a pesquisa de documentos dos ancestrais de Sueli Carneiro, trato da temática dos arquivos relacionadas a memória e 
relações raciais. Nesta parte também explico o método da pesquisa, de seleção de fragmentos textuais de mulheres negras, analisados como escrita de si e como testemunhos da resistência ao racismo, a partir de dois conjuntos: escritos categorizados como clássicos, publicados desde o século XVIII até a primeira década do século XXI, e textos aqui nomeados táticos.

Na parte dois, escrevo sobre as mulheres negras, contando uma versão da história da presença e da organização desse sujeito político no Brasil.

Na parte três, trato do racismo à brasileira, articulando o dispositivo de racialidade, contrato racial, epistemicídio e biopoder, tal como são trabalhados por Sueli Carneiro, com um paralelo à ideia de necropolítica de Achille Mbembe. Ao tratar do epistemicídio, busco traçar um paralelo com a Ciência da Informação, ao discutir as noções de informação e conhecimento. Sigo tratando da resistência, escrita de si e cuidado do outro, além de abordar a escrevivência, de Conceição Evaristo.

$\mathrm{Na}$ parte 4, os fragmentos selecionados são apresentados e analisados a partir de sete eixos: "Sobrevivência física, preservação da saúde e da capacidade cognitiva"; "Elaboração de traumas"; "Organização de sujeitos coletivos"; "Crítica aos processos de exclusão racial, social e de gênero"; "Ruptura com a subordinação e a subalternização aos discursos de dominação racial, de gênero e social"; "Olhar a partir de uma perspectiva própria" e "Proposição de caminhos de emancipação individual e coletiva".

Segue o bordado-tese. Laroyê! 


\title{
1. TEMPO, MEMÓRIA, DOCUMENTOS
}

\author{
E nos dizia com uma voz que parecia vinda de outro \\ mundo que nos enchia de angústia: "Quando eu \\ morrer, quando vocês perceberem que eu morri, \\ cubram o meu corpo. Ninguém deve ver meu corpo, não \\ se pode deixar ver o corpo de uma mãe" \\ (Scholastique Mukasonga, em A mulher de pés \\ descalços, 2017).
}

Scholastique Mukasonga nasceu em Ruanda, em 1956. Tutsi, etnia minoritária que passa a ser perseguida pela maioria hutu por incentivo dos colonizadores belgas, passou a infância e parte da juventude em um campo de refugiados.

No cenário de violência crescente, os tutsis mais escolarizados eram os alvos prioritários. Por isso, a família avaliou que era melhor ela e um dos irmãos deixassem o país, por mais arriscado que fosse. A pé e sem malas, durante a madrugada.

Só nos restava partir. No Burundi, teríamos, sem dúvida, uma chance de continuar os estudos, encontrar um trabalho. E, sobretudo - os pais não sabiam como dizê-lo - era preciso que, ao menos alguns sobrevivessem, conversassem a memória, para que a família pudesse continuar em outro lugar (...). Tínhamos sido escolhidos para sobreviver (MUKASONGA, 2019, p. 109-110).

Um genocídio não se faz da noite pro dia, como diz Mukazonga, que prefere ser chamada pelo nome na língua materna, em vez de Scholastique, o nome em francês, do colonizador. Em 1994, vinte anos depois de sua fuga, um milhão de ruandeses foram mortos a machadadas e a golpes de facão por seus vizinhos e conhecidos. Depois de mais de três décadas de invenção contínua de uma suposta inferioridade tutsi, com o cerco fechando pouco a pouco, o assassinato em massa foi concentrado em cem dias, quando 800 mil foram assassinados. Uma média de oito mil pessoas por dia. Da família de Mukasonga, 37 pessoas foram assassinadas. Todas, com exceção dela e do irmão com quem fugiu pelo Burundi.

Mãezinha, eu não estava lá para cobrir o seu corpo, e tenho apenas palavras - palavras de uma língua que você não entendia - para realizar aquilo que você me pediu. E estou sozinha com minhas pobres palavras e com minhas frases, na página do caderno, tecendo e retecendo a mortalha do seu corpo ausente (MUKASONGA, 2017, p. 7). 


\title{
Documentos, métodos e "escavação"
}

\begin{abstract}
A língua tem indicado inequivocamente que a memória não é um instrumento para a exploração do passado; é, antes, o meio. É o meio onde se deu a vivência, assim como o solo é o meio no qual as antigas cidades estão soterradas. Quem pretende se aproximar do próprio passado soterrado deve agir como um homem que escava. Antes de tudo não deve temer voltar sempre ao mesmo fato, espalhá-lo como se espalha a terra, revolvê-lo como se revolve o solo. Pois 'fatos' nada são além de camadas que apenas à exploração mais cuidadosa entregam aquilo que recompensa a escavação (BENJAMIN, 1987, p. 239).
\end{abstract}

Grada Kilomba (2019) e a pesquisadora afro-holandesa Philomena Essed (1991) já escreveram que não há modelo normativo para analisar dados sobre o racismo cotidiano. Assumo que também não há regras ou dados pré-definidos necessários a analisar a resistência ao racismo.

Em sua tese de doutorado, publicada como livro no Brasil em 2019, Grada Kilomba afirma que selecionou, das entrevistas realizadas por ela com mulheres negras, "episódios baseados nos tópicos centrais das experiências com o racismo como contados pelas entrevistadas por meio de suas biografias" (KILOMBA, 2019, p. 88).

Segundo Kilomba, a forma como o racismo se manifesta no cotidiano é sempre particular. E compilar diversos episódios dessa manifestação revela, não apenas a complexidade como se vivencia o racismo, como sua presença ininterrupta na vida de mulheres negras. Compreendo que, se é possível analisar manifestações do racismo por meio de episódios, também seja possível analisar ações de resistência. Essa forma de análise, segundo a autora, também permite escrever em um formato aproximado ao de contos, o que coaduna com seu interesse de transgressão do formato acadêmico tradicional.

Sem utilizar o termo episódio, a afro-norte-americana Jane Sharpe, ao tratar das histórias perdidas sobre a escravização de pessoas negras, e da necessidade de contá-las, afirma que só é possível fazê-lo por meio de fragmentos. Ampara-se em Toni Morrison, que descreve seus romances históricos como um tipo de arqueologia literária, de compor um mundo que só existe como fragmentos (SHARPE, 2002, p. xi).

O termo "fragmento" também é utilizado por Ecléa Bosi, ao afirmar que a memória, em vez de um repositório de lembranças a que recorremos, é o trabalho de organizar fragmentos. "A percepção plena do tempo passado é impossível. Mas a memória permite a relação do corpo presente com o passado em fragmentos, ao mesmo tempo que interfere no atual" (BOSI, 1994, p. 46-56). 
Considerando que a memória coletiva, como será desenvolvido adiante, diz respeito às memórias individuais compartilhadas e também ao mosaico que se compõe a partir dos cacos que são as memórias de cada indivíduo, parece-me adequado metodologicamente neste trabalho lidar com cacos/ fragmentos/ episódios.

Analisei, portanto, fragmentos dos escritos de mulheres negras pertinentes a comprovar, relativizar ou refutar a hipótese aqui apresentada, de que a escrita de si, pela formulação estética de sua própria existência e trabalho de memória, possibilita a constituição de subjetividades e de sujeitos coletivos que permitem resistir ao racismo.

Os fragmentos selecionados foram interpretados à luz da teoria apresentada a seguir e de informações do contexto em que a escrita se realizou, no detalhamento daquilo que é compreendido nesta tese como resistência ao racismo: buscar escapar dos processos de subjugação do dispositivo de racialidade e do biopoder; produzir conhecimento de uma perspectiva própria; ser reconhecida como produtora de conhecimento. São sete os eixos de análise:
a. sobrevivência física, preservação da saúde e da capacidade cognitiva;
b. elaboração de traumas;
c. organização de sujeitos coletivos;
d. crítica aos processos de exclusão racial, social e de gênero;
e. ruptura com a subordinação e a subalternização dos discursos de dominação racial e de gênero;
f. olhar a partir de uma perspectiva própria;
g. proposição de caminhos de emancipação individual e coletiva.

O corpus analisado compreende dois conjuntos de escritos:

1. os clássicos: publicados ao longo da história, reconhecidos aqui como textos clássicos selecionados por mim na organização da coletânea Vozes insurgentes de mulheres negras: do século XVIII à primeira década do século XXI (SANTANA, B., 2019b);

2. os táticos: produzidos a partir de convites feitos por mim, tanto em oficinas de escrita, sem terem sido publicados, quanto para a publicação na coletânea "Inovação ancestral de mulheres negras: táticas e políticas do cotidiano" (SANTANA, B., 2019a). 
Cabe detalhar neste método, as concepções empregadas para a definição de cada um dos conjuntos de texto que compõem o corpus da pesquisa.

\section{Escritos clássicos}

Um levantamento histórico de textos de mulheres negras publicados até 2013, compilados como ANEXO 1 a esta tese, reuniu informações dispersas em artigos e livros de historiografia, antropologia, sociologia, estudos literários e de grupos militantes do movimento negro e de mulheres negras.

Este levantamento, acompanhado de dados históricos de contexto, permitiu visualizar uma quantidade considerável de textos produzidos e publicados entre os séculos XVIII e XIX, ainda no Brasil escravocrata, além daqueles do século XX e início do século XXI.

Em interlocução com a jornalista Christiane Gomes, além de bailarina e coordenadora do corpo de dança do Ilú Obá de Min, coordenadora de projetos da Fundação Rosa Luxemburgo, nasceu a proposta de publicar uma seleção de escritos que pudessem ser considerados clássicos na compreensão de um pensamento de mulheres negras brasileiras. Depois de conversas elucidativas com os intelectuais e militantes do movimento negro Sueli Carneiro e Edson Cardoso, selecionei 24 textos, produzidos entre 1750 e 2014, listados no ANEXO 2, com breve apresentação de cada uma das autoras.

A seleção foi publicada pela Editora Mazza, primeira editora negra do Brasil, em parceria com a Fundação Rosa Luxemburgo sob o título Vozes insurgentes de mulheres negras: do século XVIII à primeira década do século XXI .

Conforme escrevi no posfácio do livro:

Publicar, ler e estudar a produção intelectual de mulheres negras forja novas epistemologias, valorizando o conhecimento produzido por elas e também as valorizando, individual e coletivamente, como sujeitos de conhecimento. Com este livro em mãos, mulheres negras terão a oportunidade de conhecer nosso protagonismo na formação do pensamento brasileiro e também poderão reconhecer em si mesmas, tendo estas páginas como espelho, intelectuais, pensadoras, produtoras de saber. Retomar estes textos históricos também coloca a possibilidade de compreender características próprias da diáspora africana no Brasil, ampliando um referencial que não se limita às autoras norte-americanas. Além disso, dá a oportunidade, a pensadoras e pensadores não-negros, de

\footnotetext{
${ }^{4}$ Os textos se encontram, na íntegra, no site da Fundação Rosa Luxemburgo. Disponível em: $<$ https://rosalux.org.br/wp-content/uploads/2019/08/web_Vozes_Insurgentes-1.pdf > .
} 
rever a formação do pensamento brasileiro a partir de perspectivas diversas, buscando reparar, ainda que parcialmente, os apagamentos de intelectuais brilhantes (SANTANA, B., 2019b, p. 300).

Imagem 1: Capa do livro Vozes Insurgentes de Mulheres Negras: do século XVII à primeira década do século XXI (SANTANA, B., 2019b)

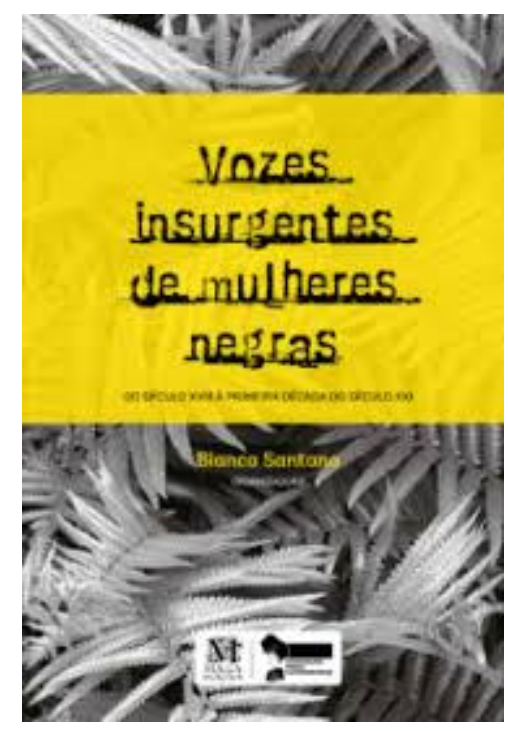

Fonte: site da Fundação Rosa Luxemburgo

\section{Escritos táticos}

Tática, segundo compreende Michel de Certeau, diz respeito à ação a partir da ausência de poder, em uma situação favorável específica. “(...) as táticas apontam para uma hábil utilização do tempo, das ocasiões que apresenta e também dos jogos que introduz nas fundações de poder" (DE CERTEAU, 1994, p. 102).

Considerando a produção e a publicação de textos autorais como uma ação que se espera de determinados sujeitos que detêm poder, ou sejam validados por poderosos, a escrita de si de mulheres negras poderia ser compreendida também como tática. Mas, neste trabalho, são considerados textos táticos aqueles produzidos em uma situação favorável específica em que mulheres negras receberam um convite para escrever sobre si e suas memórias.

O convite foi recebido em duas situações diferentes: durante a participação de oficinas de escrita; ou para a publicação do livro Inovação ancestral de mulheres negras: táticas e políticas do cotidiano, por mim organizado, com apoio da Embaixada da Áustria e publicação pela editora negra Oralituras (SANTANA, B., 2019a). No futuro, algum desses textos poderá ser reconhecido também como clássico, assim como os textos clássicos 
poderiam ser considerados táticos em outros contextos. Essa é uma classificação artificial e limitada, que tem o objetivo de explicitar como tive acesso aos diferentes conjuntos de textos.

Ainda no início do doutorado, em 2 de junho de 2017, participei da oficina Informação, Tecnologia e Sociedade, mediada pelas professoras Lucia Maciel Barbosa de Oliveira e Giulia Crippa, durante o Seminário de Pesquisa em Ciência da Informação. Depois de apresentar meu projeto de pesquisa e receber comentários e recomendações preciosas das professoras e colegas de pós-graduação, decidi acatar a sugestão do meu orientador de analisar, neste trabalho, textos produzidos em oficinas de escrita.

Desde 2016, eu facilitava oficinas, primeiro para grupos de mulheres, depois para grupos de mulheres negras, depois abertas a quaisquer pessoas. A proposta de oficinas de escrita para mulheres nasceu quando eu era professora na graduação em jornalismo da Faculdade Cásper Líbero, em São Paulo. Eu tinha uma percepção pouco fundamentada de que os textos das alunas eram menos expressivos e escritos com menos liberdades estéticas que os textos dos alunos. Minha hipótese estava relacionada à baixa auto-estima de muitas alunas em relação à própria escrita e ao desejo de atenderem a expectativas formais acadêmicas ao modularem a própria voz, tantas vezes considerada inadequada.

Ao orientar trabalhos de conclusão de curso, passei a propor exercícios de escrita de si para incentivar as alunas a buscar um estilo narrativo próprio. Eu havia sido professora na educação de jovens e adultos e sabia como a escrita autobiográfica era poderosa para aquilo que eu chamava "soltar a mão" para escrever. De fato, a partir dos exercícios propostos e de dicas pontuais, a "voz própria" de cada uma daquelas meninas e mulheres começava a aparecer. Os resultados eram reconhecidos em boas notas nas avaliações de trabalhos por outros professores e convidados externos, na própria auto-estima crescente das alunas em relação aos próprios textos, e em outras alunas da faculdade, que não eram minhas orientandas, nem minhas alunas, algumas nem sequer alunas do curso de jornalismo, passarem a me procurar para buscar ajuda para escrever.

Ofereci, em julho de 2016, oficinas de escrita com duração de 12 horas para duas turmas, com 10 mulheres cada uma, na sala da minha casa. Em dezembro, para mais duas turmas. A divulgação acontecia no boca-a-boca e redes sociais, feita por minhas amigas, colegas de trabalho, alunas e ex-alunas. No final de 2016, negociei minha demissão da Faculdade Cásper Líbero para me dedicar ao doutorado e a projetos de escrita. Mas a demanda pelas oficinas crescia, assim como o pedido de cursos mais longos. 
Então, em 2017, além das oficinas de 12 horas em períodos de férias, ofereci também duas turmas anuais de um curso de escrita para mulheres, com um encontro por semana, uma turma de manhã e outra de noite. Fui convidada a oferecer a oficina para homens e mulheres no Espaço Cult, em um seminário internacional de direitos humanos promovido pela ONG Conectas, na Biblioteca da UNESP São José do Rio Preto, na Biblioteca do Parque Villa Lobos, e o fiz entre 2017 e a metade de 2019. Em julho de 2017, ofereci a primeira oficina de escrita para mulheres negras, conforme relatado no ANEXO 2; além do projeto Samba em Primeira Pessoa: oficina de escrita e canto com Mulheres Negras, coordenado por Maitê Freitas, Carmen Faustino e Patrícia Vaz, em que facilitei oficinas de escrita ao lado de Luana Bayô, que ministrou oficinas de canto, no segundo semestre de 2017.

Por eu escrever sobre as experiências das oficinas nas redes sociais, e conversar sobre elas com muitas pessoas, inclusive com meu orientador, ele sugeriu que eu realizasse oficinas com mulheres negras como método de pesquisa do doutorado. A sugestão foi reforçada no seminário de pesquisa já citado e pela banca de qualificação formada pelas professoras Giulia Crippa, naquele momento vinculada ao programa de pós-graduação da ECA-USP, e Giovanna Xavier, da Faculdade de Educação da UFRJ.

Foram realizadas, desde então, outras cinco oficinas de escrita para mulheres negras, com apoio da Fundação Rosa Luxemburgo, na produção, deslocamentos, alimentação das participantes e distribuição de exemplares do livro Vozes insurgentes de mulheres negras (SANTANA, B., 2019b), em que foram utilizados fragmentos dos textos nele publicado como disparadores para a escrita das mulheres negras:

- em julho de 2019, na cidade de Paraty, na Casa Insubmissa de Mulheres Negras, como programação paralela à FLIP;

- em julho de 2019, no Quilombo do Campinho, também em Paraty, na Flip Preta;

- $\quad$ em agosto de 2019, na sede da ONG PACs, no centro do Rio de Janeiro;

- em outubro de 2019, em um encontro de mulheres da UNEafro, em um projeto chamado Circuladô de Oyá, na cidade de Atibaia, interior de São Paulo (nesta atividade, o apoio da Fundação Rosa Luxemburgo se restringiu à distribuição de livros para as participantes);

- em fevereiro de 2020, na cidade de Salvador, na Casa Preta, organizado pela Diálogos Insubmissos de Mulheres Negras; 
- em março de 2020, na comunidade Piquiá de Baixo, município de Açailandia, no Maranhão;

- em março de 2020, no quilombo Santa Rosa dos Pretos, no município de Itapecuru Mirim, Maranhão.

Mesmo com a diversidade de contextos e cidades, com exceção da experiência no Quilombo Santa Rosa dos Pretos, o perfil das participantes das oficinas era o mesmo: universitárias ou estudantes de pós-graduação; militantes do movimento negro e/ou do movimento de mulheres negras; militantes de movimentos populares (de educação, moradia ou atingidos pela mineração). Com idades entre 18 e 72 anos, as cerca de 160 participantes (uma média de 20 por oficina) sabiam ler e escrever, e puderam ler trechos do livro em voz alta; escrever seus próprios textos e depois lê-los para as outras participantes.

A exceção foram nove mulheres, uma idosa na oficina da Casa Insubmissa, em Paraty; duas militantes do movimento de moradia na oficina da PACs, do Rio de Janeiro, seis mulheres da comunidade Piquiá de Baixo, que tinham dificuldade de leitura e por isso não leram ou escreveram, mas compartilharam relatos orais de suas experiências a partir dos textos lidos pelas outras participantes. A oficina no quilombo maranhense foi muito diferente das demais, pela participação de meninas e adolescentes com menos de dezoito anos de idade, e de um homem, com mais de 85 anos de idade, uma das lideranças e griô da comunidade.

Apesar de não serem dados analisados nesta pesquisa, cabe mencionar o interesse de grupos de mulheres negras na realização das oficinas. Já estão agendadas para o primeiro semestre de 2020 oficinas com integrantes do bloco afro Ilú Obá de Min. Mulheres que participaram da oficina, têm replicado a metodologia em diferentes cidades e contextos, a saber: a jornalista branca Lia Rangel, em Santos, litoral de São Paulo; a historiadora negra Carolina Rocha, a partir do Rio de Janeiro, em oficinas promovidas em todo o país; a assistente social negra Luciana Reis, em um CAPs álcool e drogas na Zona Leste de São Paulo.

Em cada uma das oficinas, foram realizados de um a três exercícios de escrita por cada participante, o que significou um total de aproximadamente 320 textos escritos em papel e caneta. Na primeira oficina promovida em São Paulo, no julho das pretas, fotografei, com a autorização das autoras, 36, dos 60 textos produzidos, depois os digitei. Serão analisados estes 36 fragmentos anônimos compilados no ANEXO 4.

Tomei a decisão de não trabalhar com o total de textos produzidos nas oficinas pelas dificuldades em lidar com um volume tão grande de informações, de digitar cada um 
dos textos, e também por ter percebido que, mais do que a vivência da oficina, um convite, ainda que por e-mail, a mulheres negras para que escrevessem sobre elas mesmas era suficiente para a produção de textos táticos significativos, conforme explico a seguir.

Das oficinas de escrita realizadas até o final de 2018, nasceu o desejo de organizar um livro que permitisse a mais pessoas conhecer a escrita de si de mulheres negras anônimas, ou não reconhecidas como escritoras. "Na escrita memorialista dessas mulheres, pode-se perceber a ancestralidade, as táticas cotidianas de existência e as tecnologias sociais inovadoras que permitem a vida dessas mulheres e de suas famílias e comunidades", escrevi na apresentação do livro publicado em abril de 2019 (SANTANA, B., 2019a).

Em uma reunião com a então ministra-conselheira da Embaixada da Áustria no Brasil, Isabella Tomas, que me procurou com o objetivo de entender mais sobre o feminismo brasileiro, perguntei se a Embaixada poderia financiar a publicação de um livro escrito por mulheres negras. Pega de surpresa, lembrou de uma rubrica de suporte ao desenvolvimento e à inovação, e, em três meses, o orçamento para pagar custos de edição, revisão, impressão e a contribuição de 300 reais para cada autora estava aprovado.

Mapeei, em sites de organizações de mulheres negras, conversas com militantes, notícias de jornal, nomes de mulheres negras que têm gerado transformações relevantes em seu entorno e cheguei a centenas de nomes em todo o país. No projeto, no entanto, cabiam apenas vinte e dois textos. Enviei e-mails de convites à escrita para 40 mulheres, com a seguinte proposta:

\footnotetext{
A ideia é que você escreva sobre você, sua história, sua ancestralidade, seus corres.

Pode ser um causo específico, pontual, que seja marcante para você.

Ou pode ser uma narrativa mais geral.

Sabe aquela receita de família pra fazer a comida render?

Aquele jeito da avó de preparar as ervas?

Aquela ajuda financeira que sempre deu e sempre recebeu de quem está perto?

Aquela vez que você achou que tudo iria dar errado, mas se conectou com a ancestralidade e fez o jogo virar?

Aquela magia das pretas, de com pouco fazer muito?

É isso :)
}

A esse convite, recebi 26 textos, quatro a mais que o previsto, editados por Maitê Freitas, diagramados por Ariane Cor - ambas também autoras -, disponibilizados em PDF na internet, com mil cópias impressas, distribuídas em apenas 3 meses. A coletânea é composta por 27 textos porque, ao receber a negativa da sambadeira, cantora e cuidadora 
espiritual do bloco Ilú Obá de Min, Nega Duda, ao convite, com a justificativa de não saber escrever, o que não é verdade apesar da percepção de Nega Duda, me ofereci para entrevistá-la e transcrever o áudio, conformando assim um texto para o livro. Ela aceitou, enviei para ela a transcrição sem nenhuma modificação, depois de três pequenos ajustes feitos por ela, o texto estava pronto para ser publicado. Uma minibiografia de cada autora está compilada nesta tese como ANEXO 5 e os textos, na íntegra, estão disponíveis online 5 .

Somando os 36 textos resultantes da oficina aos 27 produzidos para o livro, foram analisados 63 escritos táticos nesta tese.

Imagem 2: Oficina de escrita realizada no "Julho das Pretas", em 2017

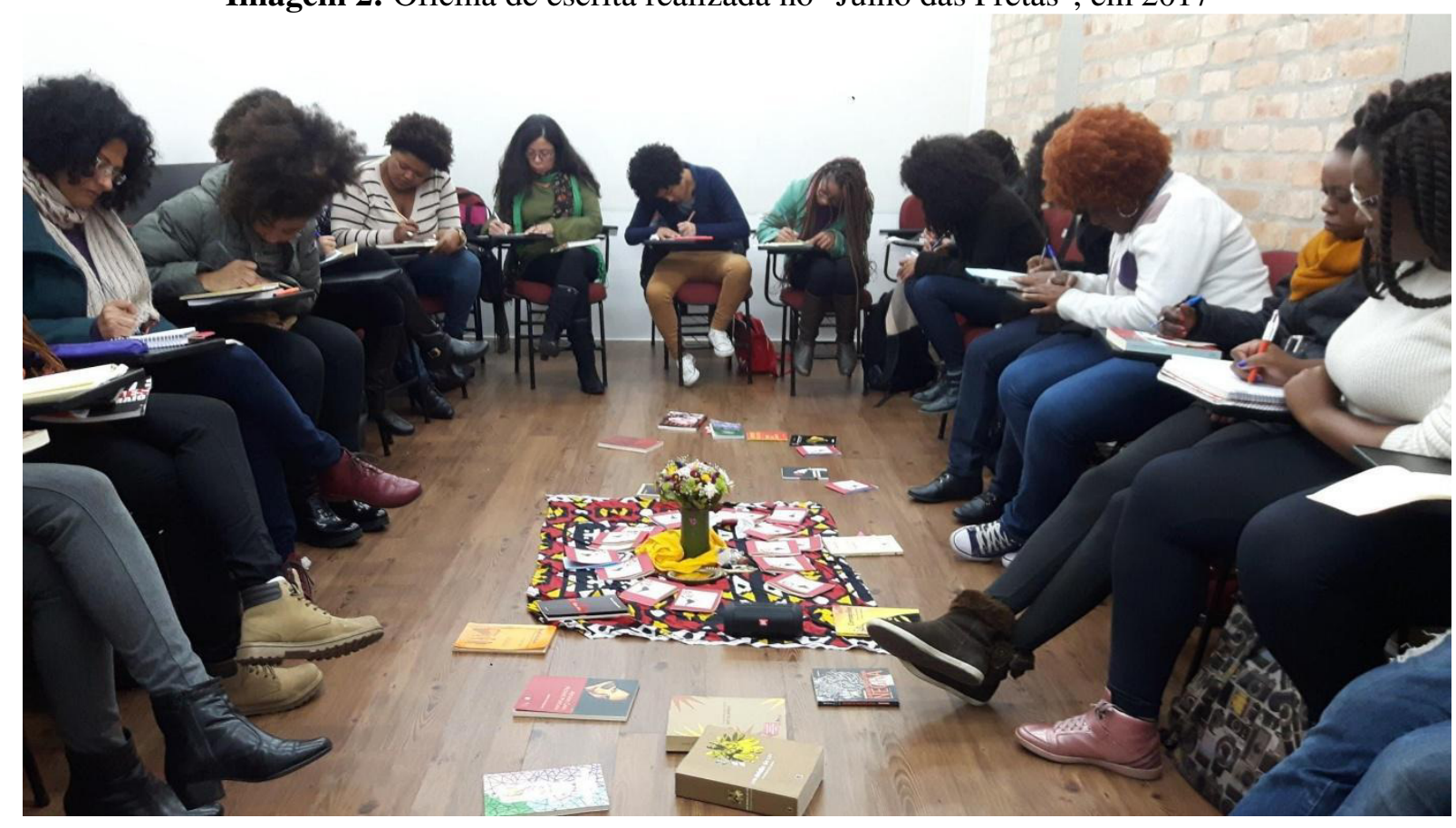

Fonte: Arquivo Pessoal

Há grande diferença entre as oficinas de escrita e um convite feito por e-mail para que fosse produzido um texto. A principal dela diz respeito a aspectos que não seriam analisados nesta tese: a interação entre autoras; os comentários e tessitura da mediadora; os efeitos da leitura do próprio texto em voz alta.

A título de esboçar uma reflexão que não será aqui aprofundada, há performance na leitura em voz alta da escrita de si; e com aspectos ritualísticos quando ela acontece em círculo, para outras mulheres negras, com livros significativos para aquele conjunto de pessoas no círculo.

\footnotetext{
5 No site da Editora Oralituras. Disponível em: <http://oralituras.com.br/wpcontent/uploads/2019/05/inovacao-de-mulheres-negras_2019_web_site.pdf>.
} 
Paul Zumthor, sobre a performance, fala do investimento de energia corporal que interfere no contato com um texto. A obra, não seria então o texto, mas a performance que o corpo realiza a partir do texto. Quem ouve o texto e o interpreta também gera novos textos, e leituras e obras. A riqueza das oficinas mora no que poderíamos, então, chamar performance.

Isso não significa dizer que performar a leitura do próprio texto em voz alta seja prazeroso ou confortável para todas as mulheres. Há constrangimentos e deslocamentos que, desde acolhidos pelo coletivo, podem também ser objeto de reflexão conjunta e de treino para mulheres negras, muitas vezes, acostumadas ao silêncio. Mas o objeto de análise deste trabalho é a escrita de si de mulheres negras.

Imagem 3: Cartaz de divulgação do livro Inovação ancestral de mulheres negras: táticas e políticas do cotidiano (SANTANA, B., 2019a)

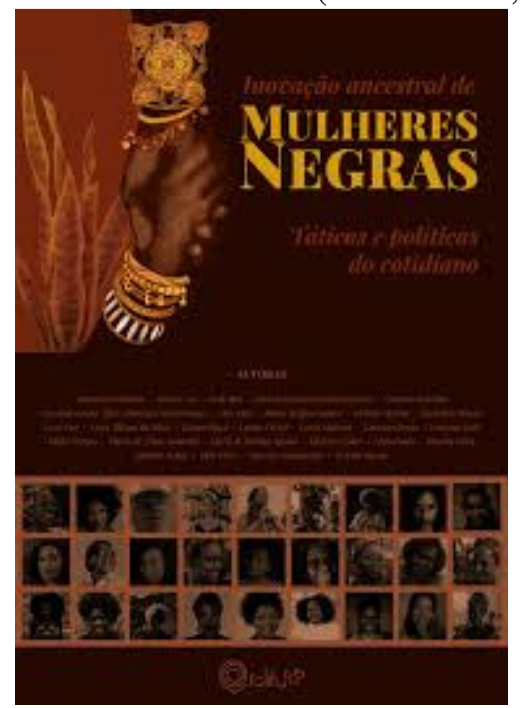

Fonte: Arquivo pessoal

Mas antes de chegar à escrita de si de mulheres negras, será apresentada uma reflexão acerca do tempo, seguida pelos contextos que conformaram essas escritas: o processo de auto-construção da identidade das mulheres negras (capítulo 2) e a constituição de um dispositivo de racialidade e biopoder no racismo brasileiro (capítulo 3)”.

\section{Sobre Tempo e o tempo}

Tempo, no candomblé angola, é nkisi. A bandeira branca hasteada onde se cultua o Tempo é símbolo da nação. Seu espaço ritual é "no tempo", sem cobertura, debaixo de uma árvore - símbolo da vida, do tempo e da memória em tantas culturas. Pelas raízes das 
árvores está representada a ancestralidade e a conexão com a terra; pelos galhos as expressões do próprio tempo e conexão com o ar. Tempo é que permite que a vida aconteça, cria e desconstrói regras. "Tempo é o que não se sabe sobre ele” (MACHADO, V., 2015).

E o tempo, que se diferencia do nkisi Tempo, é, entre os povos bakongo, aquele que permite o funcionamento da vida. Segundo explica Fu-Kiau, a existência se torna compreensível pelo entendimento do tempo, que é cíclico e possui duas dimensões: uma abstrata e outra concreta. Na concepção abstrata não tem começo nem fim, está sob o poder da energia cósmica/ força suprema. Já o tempo concreto, dunga, diz respeito a eventos que podem ser naturais, artificiais, biológicos, materiais etc. (MACHADO, V., 2015).

Para este tempo concreto, há pelo menos outras cinco palavras: tempo Ntangu: contar, pôr em ordem, acumular ou dividir em etapas; tempo Tandu: marcar ou definir; tempo Kolo: estado de ser, nível de força em um tempo determinado; Lokula e ndo: conceito de hora.

O tempo está em todos nós, que, como partes do universo, também somos parte do tempo. O dingo-dingo [processo do fogo cósmico em expansão/ criação- transformação/ funcionamento] pode ser dividido por quatro barragens do tempo, e nós também somos as próprias barragens: musoni: começo de todos os tempos; kala: nascimento/ início da vida biológica; tukula: amadurecimento da vida, momento mais prudente; lubemba: movimento de retorno ao mundo espiritual, grande mudança, desintegração. (MACHADO, V., 2015, p. 22). 
Imagem 4: Diekenga - cosmograma Bakongo

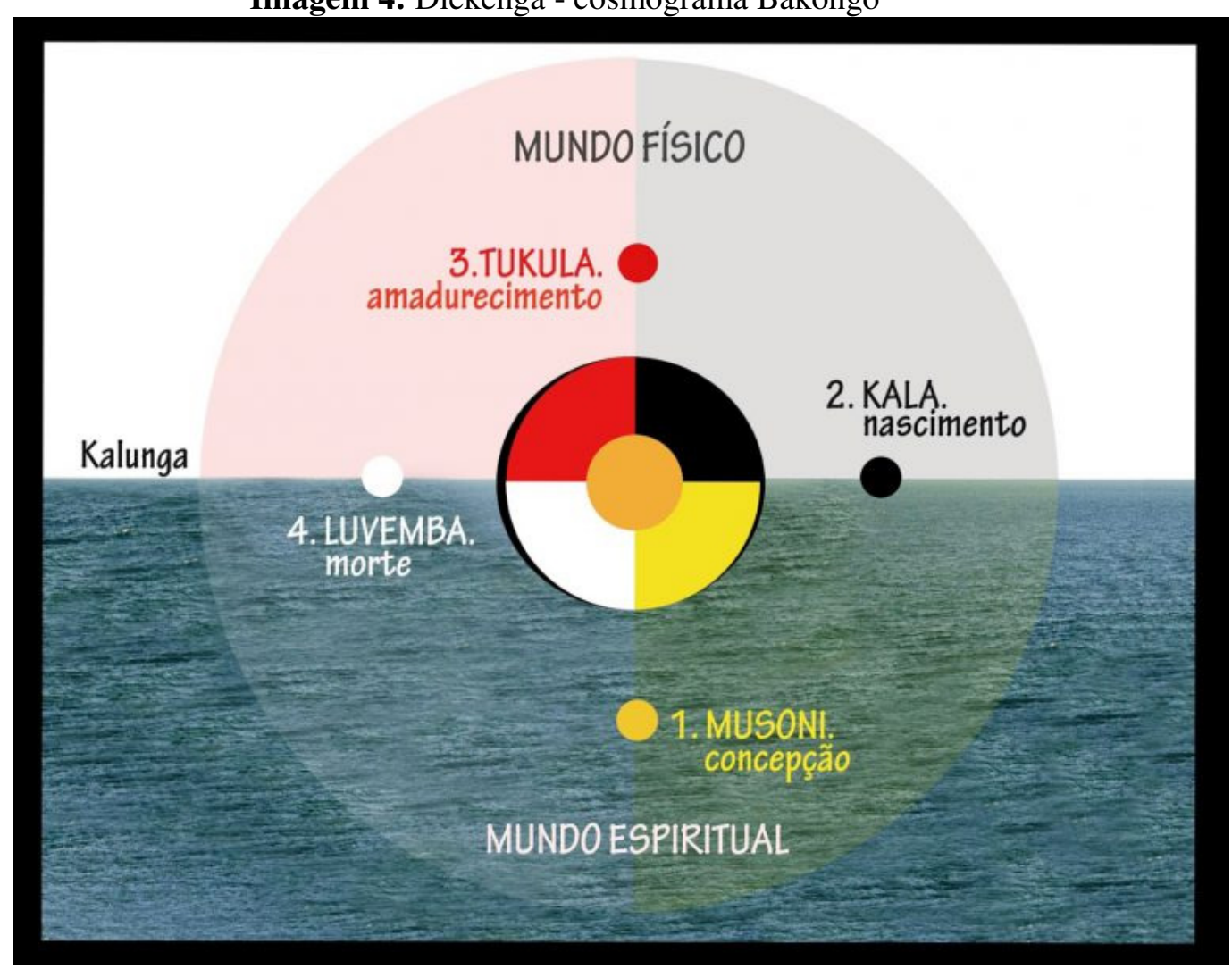

Fonte: Universidade Federal da Bahia.

Disponível em: <http://www.edgardigital.ufba.br/?p=6464>

É muito difícil compreender tal complexidade em relação às nossas categorias temporais de passado, presente e futuro. Primeiro, por não haver linearidade, depois pela complementaridade, na não existência de um tempo independentemente do outro, como em um paralelo com o que o senso-comum costuma traduzir de ubuntu: eu sou porque nós somos.

O que chamamos passado tem grande importância entre os bantu pois, sem ele, o presente não existiria. E o futuro não pode ser definido por não tratar de eventos, lembrando que o tempo concreto diz respeito a eventos e o tempo abstrato não pode ser medido. Mas a inexistência de algo parecido com o futuro não impossibilita a noção do devir ou que se faça planos. Ao contrário, planeja-se com a certeza de que os descendentes darão continuidade, no devir, ao que for planejado hoje. E todo o presente é guiado por uma percepção da ancestralidade.

No Brasil, a noção de tempo banto se encontra com noções indígenas e europeias, apresentando ainda diferentes camadas e complexidades a partir dessa relação (MACHADO, V., 2015), o que bem explica Allan da Rosa: 
Nesse tempo tradicional africano não existe um fim absoluto a ser perseguido nem sequer um final do mundo previsto, mas a geração e o giro de formas a se relacionar com a precariedade e com a permanência no mundo, que é nitidamente ambivalente no seu cotidiano. Modelado nesse termo, o lugar afro-brasileiro existe num entre-lugares e também se faz teia, num entre tempos. Pois é trança entre repetição e inédito (Rosa, 2019, p. 43).

A noção de temporalidade entre os nagô também está calcada na relação com a ancestralidade, e ela se separa do que podemos interpretar como tempo mítico. Muniz Sodré, explica sobre a filosofia nagô: “(...) diferente do tempo histórico, a temporalidade em que se inscreve o destino é própria da ancestralidade, isto é, da vigência ética do discurso de fundação do grupo, em que se enlaçam origem e fim” (SODRÉ, 2017, p. 109). Mais uma vez, um devir que é o passado; um passado que é o devir.

Há um mito iorubá em que Exu mata um pássaro ontem, com a pedra que arremessa hoje. Exu, o mensageiro, o que abre os caminhos, o que faz a ligação da humanidade com os orixás. "O dinamismo mítico pode também ser lido como a própria natureza do inesperado, da penetração das fissuras do universo ordenado (...)" (SODRÉ, 2017, p. 174). Muniz Sodré explica que o conceito ocidental do tempo se origina quando se começa a pensar na duração como algo independente dos ciclos ou processos, mas como abstração estabelecida por um cânone de medida (SODRÉ, 2017, p. 181). Mas muito da filosofia ocidental já foi dedicado a tratar desse tempo representado e datado. O tempo de Exu não pode se inserir em uma narrativa com passado, presente e futuro porque a ação de Exu não está dentro do tempo, ela inventa o tempo (SODRE, 2017, p. 188).

\footnotetext{
$\mathrm{Na}$ temporalidade que experimentamos em nosso cotidiano historicamente normalizado, permanecemos ligados à transitoriedade dos acontecimentos, regida pela linearidade do antes e depois. Nela, só se pode conceber o acontecimento referido no aforismo de Exu como 'extratemporal', portanto, como pertencer a um 'não tempo', uma temporalidade mítica (SODRÉ, 2017, p. 191).
}

Talvez o aforisma de Exu possa ser o caminho de uma compreensão mais refinada do tempo que, certamente, não tenho condições de apresentar nesta tese.

É importante saber que, em uma perspectiva africana, a referência maior de tempo é o passado, porque nele está a sabedoria dos ancestrais e no passado residem as respostas para os mistérios do presente (OLIVEIRA, Eduardo, 2003). O tempo presente - que contém o passado, na trança nomeada por Allan da Rosa - é o tempo da vida, e para orientá-lo é importante que se ouça as vozes do passado. 
O que veio antes, a ancestralidade, pode se conectar ao humano pelo fio da memória. "A memória viceja no tempo presente - eis onde vige o ancestral, como ntima, mesmo termo kikongo para coração" (SANTOS, T., 2019, p. 155). Assim como na origem do latim: saber de memória, saber de cor, de coração. A memória é encarnada pelo que pulsa. "E tudo, como estamos a ver, vibra a anterioridade, o presente, o devir. Tudo vibra memória - linha de força que reúne as temporalidades possíveis" (SANTOS, T., 2019, p. 156).

Ao enviar o trecho a Taata Mutá Imê, para pedir autorização para publicar e correções a possíveis equívocos, ele respondeu, por WhatsApp: "Memória que só pode ser vivida com o mutuê (cabeça), falada e sentida com a muxima (coração)". O trabalho de lembrar é racional, mas a partilha da memória, pela linguagem, passa pelo que se sente em relação a este lembrar. Estava refletindo sobre a complexidade da afirmação e pensando que muito tempo será necessário a mim para compreender mais sobre o tempo, quando Mutá Imê continuou:

Cabeça não fala minha filha, ela foi feita pra pensar, vê a direção com tempo, no tempo, para Tempo. Velocidade, ação determinação. Nós, bantus, falamos com o coração, que nos guia, dirigindo o caminho para a estrada. Só assim podemos voltar da estrada para o caminho e vise versa. Cabeça foi feita pra trazer as memórias que se registra através do coração.

Segundo Mutá Imê, essas reflexões sobre o tempo e a memória lembram as longas conversas que teve com os mais velhos, que já morreram, e lamentou que não estejam mais aqui para ensinar ainda mais. Ainda bem que Mutá Imê está.

\section{Memória individual e coletiva}

Essa preta que canta

Essa preta que dança Esse canto que vem de lá

África

Lia de Itamaracá

(Trecho de Cirandar com Lia, de Beth Beli e Adriana Aragão, repertório do Carnaval 2020 do bloco afro Ilú

Obá de Min)

Ilú e o seu mar de mulheres movimentam os sons ancestrais A caminho do encontro das águas $e$ das bênçãos dos orixás 
Temperando memórias sagradas

Venha Lia, pra nos encontrar!

Nos traz o tambor e a roda

Ecoando Itamaracá

(Trecho de Memórias Sagradas na Ciranda do Mar, da

Coletiva do Xequerê, repertório do Carnaval 2020 do

bloco afro Ilú Obá de Min)

Não sei se sou eu que danço a ciranda

Ou ela que me leva

(Trecho de Saia de Lia, de Lenita Sena, repertório do

Carnaval 2020 do bloco afro Ilú Obá de Min)

Sem evocar qualquer referência banto ou iorubá, Ecléa Bosi define memória como um trabalho sobre o tempo vivido, convocado no tempo presente tanto pelo indivíduo como pela cultura. Não se trata de um repositório de lembranças a que recorremos, mas da própria atividade de lembrar, da organização de fragmentos de um cabedal infinito de possibilidades.

A percepção plena do tempo passado é impossível. Mas a memória permite a relação do corpo presente com o passado em fragmentos, ao mesmo tempo que interfere no atual. Há muita relação, portanto, com a perspectiva banto de memória como vibração que reúne as temporalidades possíveis. Nas palavras de Ecléa, pela memória, o passado se mistura às percepções imediatas e também as desloca, com força subjetiva, profunda e ativa (BOSI, 1994, p. 46-56). A memória só pode ser socializada pela linguagem, seja ela corporal, escrita, falada, dançada, ritualizada (BOSI, 1994, p. 38-56).

Assim, nesta tese, memória é compreendida como o fio que conecta temporalidades, pelo trabalho ativo de lembrar e expressar lembranças por diferentes linguagens.

$\mathrm{Na}$ tese de doutorado sobre memória defendida na Faculdade de Psicologia da USP, em 1979, publicado e republicado desde então no clássico Memória e sociedade: lembranças de velhos, Ecléa Bosi explica a existência de duas memórias: a memóriahábito, dos mecanismos motores; e a imagem-lembrança, que traz à tona da consciência um momento específico. A memória-hábito é aquela que incorporamos no vivido, como modos de ser e fazer, que muitas vezes não percebemos de forma consciente. Guardada no corpo como esquemas de comportamento, se manifesta de forma automática nas práticas do dia-adia e se mistura com a percepção do presente. Já a imagem-lembrança tem caráter evocativo e se refere a uma situação definida, com data certa. São lembranças independentes dos hábitos, isoladas, singulares que se instituem como imagens ressuscitadas do passado. 
Como a memória se realiza sempre no presente, nossos deslocamentos alteram o que lembramos. Ao localizar uma lembrança, desenrolamos fios de meadas diversas, em um ponto de encontro complexo das convergências dos muitos planos do passado e do presente (BOSI, 1994, p. 413). Como afirma Eduardo Oliveira (2003), também para povos tradicionais africanos, os protagonistas do presente ouvem, respeitam e cultuam os ancestrais para abrir caminhos para novos tempos. A tradição, então, é o fundamento da atualização.

\begin{abstract}
Conhecemos a tendência da mente de remodelar toda experiência em categorias nítidas, cheias de sentido e úteis ao presente. Mal termina a percepção, as lembranças já começam a modificá-la: experiências, hábitos, afetos, convenções vão trabalhar a matéria da memória. Um desejo de explicação atua sobre o presente e sobre o passado, integrando suas experiências nos esquemas pelos quais a pessoa norteia a vida. $\mathrm{O}$ empenho do indivíduo em dar um sentido à sua biografia penetra nas lembranças como 'um desejo de explicação (BOSI, 1994, p. 419).
\end{abstract}

Quem lembra é a pessoa, por mais coletivas que possam ser as memórias. "Ele [o indivíduo] é o memorizador e das camadas do passado a que tem acesso pode reter objetos que são, para ele, e só para ele, significativos dentro de um tesouro comum”. Cada memória individual, portanto, é um ponto de vista sobre a memória coletiva (BOSI, 1994, p. 411413). Ao mesmo tempo em que uma memória torna-se coletiva na possibilidade de ser compartilhada (CRIPPA, 2012). Deve-se considerar que o conjunto de lembranças de um grupo é também construção social do grupo, visto que o significado coletivo pode aumentar o brilho de uma cena lembrada, ou mesmo alterar aquilo que o indivíduo lembra. A percepção coletiva, assim, é conformada pela individual, mas também influencia aquilo que o indivíduo lembra. Diaxética, como diria o poeta negro Arnaldo Xavier, ou, dialética. Na percepção de Giulia Crippa, a dimensão da memória se desenvolve pela dialética do dizer ao outro, e de se escutar o outro.

$\mathrm{Na}$ busca das formas em que se elaboram os dizeres e seus relatos, a memória individual é criada enquanto compartilhada com os outros. $\mathrm{Na}$ seleção das palavras e de sua ordem, nos dizeres utilizados pelas narrativas da memória emerge a complexidade das relações entre o indivíduo e o mundo. O compartilhamento das memórias não é, assim, o conjunto de lembranças em comum, mas, sim, a construção da linguagem por meio da qual elas podem ser transmitidas (CRIPPA, 2012, p. 59).

Scholastique Mukazonga, ao escrever sobre a infância e a juventude em Ruanda, registrou memórias-hábito, do cultivo do sorgo, das plantas de bom augúrio a serem 
colocadas em casa, dentre tantas outras; e, imagens-lembrança, cenas únicas, episódios vividos em um determinado tempo e lugar, por determinadas pessoas. Memória individual, de comportamentos apreendidos e episódios vivenciados no grupo, realizada como trabalho ativo de lembrar e compartilhar pela escrita, por isso também coletiva. Além de sobrevivente de um genocídio, ao contar, Scholastique Mukasonga se apresenta também como testemunha.

Sueli Carneiro se utiliza, em sua tese de doutorado, da noção de testemunho de Seligmann-Silva (2004), desenvolvida a partir das tradições alemã, marcada pelas memórias da Segunda Guerra, e latino-americana, em que prevalecem as lembranças das ditaduras militares, da luta pela terra e por direitos. Da tradição alemã, Seligmann-Silva destaca o evento central nos discursos testemunhais, concebido como algo de radical unicidade: a Shoah, o holocausto. Sueli Carneiro afirma que as testemunhas do racismo no Brasil possuem características de ambas as tradições: são sobreviventes de um evento de radical unicidade que foi a escravização de seus ancestrais africanos, "cujos efeitos permanecem persistentes em sua memória, em seus corpos, em suas vidas e na história de seu país" (CARNEIRO, S., 2005, p. 153), e são também portadoras de uma contranarrativa que ressignifica os assujeitamentos, estigmas e estereótipos.

A memória, do ponto de vista da psicologia, é também uma tentativa de elaboração simbólica de traumas. Ao analisar exemplos de sobreviventes do holocausto e seus descendentes, Jeanne Marie Gagnebin (2018), afirma que, mesmo que quisessem esquecer, não conseguiriam.

É próprio da experiência traumática essa impossibilidade do esquecimento, essa insistência na repetição. Assim, seu primeiro esforço consistia em tentar dizer o indizível, numa tentativa de elaboração simbólica do trauma que lhes permitisse continuar a viver e, simultaneamente, numa atitude de testemunha de algo que não podia nem devia ser apagado da memória e da consciência da humanidade (GAGNEBIN, J., 2018, p. 99).

A escravidão, como afirma Sueli Carneiro (2005), foi um evento de unicidade radical de grandes proporções para os descendentes de africanas e africanos escravizados no Brasil. Portanto, fonte de muitos traumas individuais e também coletivos. Nas palavras da negra norte-americana Jenny Sharpe, a escravização segue como 'história assombrada' que continua a perturbar a vida atual das pessoas negras na diáspora. As histórias do passado continuariam a vagar por não terem sido devidamente contadas. 
Escravizados acreditavam que as sombras permanecem na terra, para trás, a menos que os rituais de enterro adequados fossem realizados. Suas histórias perdidas podem ser compreendidas como uma violência análoga ao desenraizamento que negou a africanos do Novo Mundo seus rituais fúnebres" (SHARPE, 2002, p. xi).

Escrever sobre este passado que se atualiza nas vivências do racismo seria, então, uma maneira de ressuscitar uma experiência coletiva traumática e enterrá-la adequadamente" (KILOMBA, 2019, p. 223). Sobre isso também escreveu bell hooks: "O mortos nos conclamam a lembrar. Alguns de nós não abandonaram esses ensinamentos. Ouvimos a voz de nosso passado africano insistindo para que nos lembremos que 'um povo sem ancestrais é como uma árvore sem raízes"” (hooks, 2019a, p. 319). Segundo Gagnebin (2018, p. 105): "Um trabalho que, certamente, lembra dos mortos, por piedade e fidelidade, mas também por amor e atenção aos vivos".

Como ressaltou Gabriela Leandro Pereira, professora da Universidade Federal da Bahia, ao avaliar esta tese, pelas trajetórias familiares, os deslocamentos, às vezes forçados, às vezes voluntários ou constrangidos pós-escravidão, são característicos das trajetórias das famílias negras. "É importante encontrar um lugar para o trânsito, ou errância, como escreve o poeta Edimilson de Almeida Pereira, em Caderno de Retorno: 'Estou de volta à casa não para visitar os carneiros de minha gente, uma vez mortos, expostos. O que espero deles não é carne, mas raiz e errância'".

Na desumana travessia do Atlântico, a brutal violência da escravidão e as inúmeras dificuldades impostas pelos racismo institucional e a discriminação da pós-abolição, que se mantém ainda hoje, as mulheres negras trançam seus cabelos, cantam, dançam, adornam seus corpos, contam histórias, utilizam ervas para curar dores, fazem roupas de boneca. A afirmação e recriação de costumes e hábitos de diversas etnias, portanto, inscreveram no cotidiano das mulheres negras brasileiras condutas específicas. Nas palavras da antropóloga Fernanda Carneiro (2006, p. 23) “condutas, com conteúdos e táticas de uma liberdade vivida sob tensão e funcionam como memória coletiva, inscrevendo na cultura e no cotidiano uma crônica alternativa de vida". Memórias-hábito (BOSI, 1994); signos culturais, textuais e constituições simbólicas que não se apagaram no corpo individual nem no corpus coletivo de pessoas negras (MARTINS, L., 1997), conhecimentos enraizados no corpo, ativados constantemente (TAYLOR, 2013, p. 17).

O passado, então, orienta a construção de uma memória que é do presente, a serviço do presente. Nem mesmo nos contextos extremos deixamos de narrar. "De fato, ao longo da 
vida, para construir um sentido, para nos construirmos, jamais deixamos de contar, em voz alta ou no segredo da nossa solidão: nossas vidas são completamente tecidas por relatos, unindo entre eles os elementos descontínuos", escreveu Michèle Petit (2009, p. 127), ao analisar experiências de mediação de leitura na América Latina e Europa. "De fato, em contextos de crise, individual ou coletiva, quem analisou os fatores que trabalham para a reconstrução do indivíduo sublinhou a importância de dois elementos: a qualidade do contato com os outros e a possibilidade tanto de tecer uma narração a partir de experiências descosturadas, dando-lhes sentido, coerência, quanto de exprimir suas emoções diferentemente, e compartilhá-las” (PETIT, 2009, p. 127).

Foi assim também no período da escravidão. "As contadeiras de histórias, as pretas velhas, as cantigas e as palmas, tudo são ensinamentos e valores de uma tradição corporal que dão sustento, estruturam personalidades e transmitem uma pedagogia" (CARNEIRO, F., 2006, p. 23). Cabe supor que a experiência corporal das mulheres negras, como memória coletiva, é também um processo de elaboração do passado e do trauma (GAGNEBIN, 2018) da escravidão, do racismo e da discriminação. “A expressão corporal negra retoma o devir das particularidades e garante uma continuidade e permanência étnica que não se justifica por leis naturais" (CARNEIRO, F., 2006, p. 24).

Vale ressaltar, como se verá adiante, que esta memória não é composta somente de

dores. É também a grande capacidade de mulheres negras, em um cenário tão restritivo, de se constituírem como sujeitos e produzirem informações e conhecimento. Assume-se, então, neste trabalho que escrever as memórias de mulheres negras é também a possibilidade de criar o tecido, uma mortalha grande o bastante, para cobrir os corpos de negras e negros vítimas da escravização e do dispositivo de racialidade e do biopoder que configuram o racismo brasileiro.

\section{Memória e arquivo}

A noção de memória norteia diversas práticas de constituição do patrimônio documental e é configurada na arquivologia pelo conjunto de técnicas de avaliação e seleção.

A constituição dos acervos permanentes/históricos dos arquivos públicos é feita a partir da relevância social atribuída a documentos, que justifique sua preservação. Tal avaliação é técnica e também política (JARDIM et al., 1995). 
Considerando como o dispositivo de racialidade e biopoder opera no engendramento do racismo brasileiro, a importância do epistemicídio nessa configuração, e a relativa ausência do debate racial na ciência da informação, cabe questionar se, dentre os critérios de avaliação e seleção de acervos, há a promoção da equidade racial e o combate ao racismo, ou, se, ao menos, o dado objetivo de negras e negros serem 54\% da população brasileira é considerado.

Da mesma forma que pesquisadoras e pesquisadores mapearam a presença do debate racial na ciência da informação, conforme apresentado adiante, os pesquisadores Izabel França de Lima, Sergio Rodrigues de Santana, Henry Poncio Cruz de Oliveira, Mirian de Albuquerque Aquino, buscaram informação étnica-racial, em termos utilizados por eles, referente ao período de 2000-2013, em bibliotecas digitais, repositórios digitais e periódicos eletrônicos relacionados aos cursos de graduação e aos programas de pósgraduação em arquivologia.

As temáticas mais encontradas, conforme se pode ver no quadro abaixo, são informação étnico científica; inclusão de Afro-descendentes; África e Brasil. Em seguida, informação étnico-racial; reconfiguração das imagens de sujeitos negros; memória negra; movimento negro, cada temática com dois trabalhos publicados. 
Quadro 1: Temáticas acerca da informação étnico racial (conforme nomenclatura utilizada pelos autores)

\begin{tabular}{|l|c|}
\hline \multicolumn{1}{|c|}{ Temáticas } & Número de trabalhos \\
\hline África e Brasil & 05 \\
\hline Ações afirmativas & 01 \\
\hline Saúde da população negra & 02 \\
\hline Bibliotecas & 02 \\
\hline Capoeira & 01 \\
\hline Comunidade Quilombola & 01 \\
\hline Desigualdades Étnico-Raciais & 01 \\
\hline Educação antirracista & 01 \\
\hline Escravos (as) & 01 \\
\hline Exclusão & 01 \\
\hline Feminismo Negro & 01 \\
\hline Imagens da Escravidão Africana & 01 \\
\hline Hip Hop & 01 \\
\hline Identidade afro-descendente & 01 \\
\hline Imagens & 02 \\
\hline Inclusão de Afro-descendentes & 04 \\
\hline (in) visibilidade dos (as) Negros (as) & 01 \\
\hline Literatura Afro-Brasileira & 01 \\
\hline Língua Africana & 01 \\
\hline Memória Negra & 02 \\
\hline Movimento Negro (Brasil) & 02 \\
\hline Negro (a) em Santa Catarina & 01 \\
\hline Negro (a) e Telenovela & 01 \\
\hline Protagonismo Negro & 01 \\
\hline Racismo & 01 \\
\hline Representaccões da escravidão no Brasil & 06 \\
\hline Samba de Coco & 01 \\
\hline Temática afro-brasileira e negra (informação étnico-racial) & 03 \\
\hline
\end{tabular}

Fonte: Dados da Pesquisa-2013/2014

Fonte: (LIMA et al., 2017)

Não é exagero, portanto, afirmar a ausência da temática racial nas pesquisas em arquivologia e ciência da informação. A pesquisa, portanto, reflete algo que pesquisadoras e pesquisadores afirmam sobre a própria noção de patrimônio cultural no Brasil:

“(...) 'a maior parte dos bens preservados expressariam o nicho luso-brasileiro, agrário e escravista da nossa cultura, pouco acessível a uma população que tenderia à indiferença a este patrimônio 'de um país distante e alheio"” (JARDIM et al., 1995).

É importante registrar o esforço empreendido por pesquisadoras e pesquisadores negros da ciência da informação em tornar o campo mais aberto às demandas sociais. Maria Aparecida Moura, professora da Universidade Federal de Minas Gerais, tem proposto reflexões de como a compreensão de atores sociais em contextos informacionais tem colocado dificuldades teóricas para o campo e, a partir disso, é necessária a construção de 
novos consensos e terminologias. A partir do conceito de competência informacional, trata da necessidade de se consolidarem estratégias para que as comunidades possam se apropriar de novos padrões de compartilhamento, preservação e disseminação da informação de interesse público. Pela compreensão des novas dinâmicas e sua incorporação a projetos comunitários, a pesquisadora defende que se poderá efetivar o fortalecimento dos laços sociais e a construção pactuada da solidariedade em rede (MOURA, 2011).

Às limitações na pesquisa da temática racial na ciência da informação e arquivologia e à ainda incipiente reflexão crítica sobre memória e racialidade para a construção de critérios de seleção e organização de arquivos, apesar dos esforços de pesquisadoras e pesquisadores negros da área, soma-se a crença de que todos os documentos relacionados à escravidão negras foram destruídos no Brasil. É fato que, em 14 de dezembro de 1890, o então ministro da fazenda Ruy Barbosa assinou um despacho afirmando que a república era "obrigada a destruir esses vestígios por honra da pátria e em homenagem aos deveres de fraternidade e solidariedade para com a grande massa de cidadãos que a abolição do elemento servil entraram na comunhão brasileira". A ordem de destruir documentos buscava proteger o Estado brasileiro do pagamento de indenizações a fazendeiros que se sentiam prejudicados pela abolição; nada relacionado à honra.

Mas, além de a ordem não ter sido totalmente cumprida, pensando no tamanho e na complexidade do Brasil, não é plausível acreditar que cada órgão vinculado à Fazenda teria, de fato, queimado seus registros; haveria ainda as igrejas, dioceses, congregações, ordens, irmandades, santas casas, os diversos cartórios, tribunais, câmaras e outras instituições repletas de arquivos sobre negras e negros escravizados e seus descendentes. Parte importante deste material espera a chegada de pesquisadoras e pesquisadores interessados em desenterrar nossa experiência traumática, para organizá-las e permitir que sejam visibilizadas, reconhecidas, contadas e, assim, enterradas da forma adequada.

Em 1977, Abdias Nascimento listou recomendações que o congresso do Segundo Festival Mundial de Artes e Culturas Negras e Africanas, realizado na Nigéria, deveria fazer ao governo brasileiro. No discurso proibido, publicado como ensaio, constava:

Este colóquio recomenda que o governo brasileiro localize e publique documentos e outros fatos e informações possivelmente existentes em arquivos privados, cartórios, arquivos de câmara municipal de velhas cidades do interior, referentes ao tráfico negreiro, à escravidão e à abolição; em resumo, qualquer dado que possa ajudar a esclarecer e aprofundar a compreensão da existência do africano escravizado e seus descendentes (NASCIMENTO, A., 2016, p. 172). 
As informações possivelmente existentes, de fato, existem. Durante pesquisa da biografia de Sueli Carneiro, a que me dediquei entre 2018 e 2020, a ser publicada nos próximos meses, experimentei escavar documentos relacionados a seus ancestrais paternos. Com mais tempo e recursos, teria chegado, certamente, a mais informações, não só de um ramo da família paterna, mas também de outros ancestrais. Sem a pretensão de esgotar as possibilidades de pesquisa em arquivos, relato abaixo uma experiência localizada, que pode servir como base para pesquisas mais densas.

\section{Os documentos de nossos antepassados existem e estão esperando por nós}

Sueli Carneiro sabia que seu pai, José Horácio Carneiro, era filho de Horácio e Olímpia e que nascera em Rodeiro de Ubá, Minas Gerais, em 1916. Mais nada. A única tia viva de Sueli Carneiro, Nadir, poderia ter mais informações, mas ela não queria que, aos 93 anos de idade, a tia fosse incomodada com perguntas que poderiam remeter à dor e ao que gostaria de esquecer, em vez de lembrar.

Geraldo, irmão de Sueli, quatro anos mais novo que ela, o mais velho dos homens, me contou que o pai José Horácio, aos 17 anos de idade, fugira à cavalo da situação de semi-escravidão que vivia em uma fazenda. Conversas que os meninos escutavam na infância enquanto os homens bebiam ao redor do poço, na casa da avó Olímpia, já em São Paulo. Já as meninas não ouviam essas histórias.

Sueli, as três irmãs e os três irmãos, não lembram de ter ouvido nomes ou sobrenomes de bisavós ou de saber a origem do sobrenome Carneiro. Nunca ouviram nomes de bisavós ou sobrenomes de quaisquer pessoas, sabiam apenas que os antepassados eram pessoas da roça, que trabalhavam em terras de coronéis antes e depois do tempo da escravidão legal. Talvez por isso, e por terem sempre ouvido que Ruy Barbosa havia mandado queimar "todos os documentos", desenhar uma árvore genealógica não se apresentava como possibilidade.

Depois de buscas online que não resultaram nenhuma outra informação, peguei um ônibus de São Paulo a Juiz de Fora, onde aluguei um carro, prevendo que precisaria rodar a Zona Rural e outras cidades próximas a Ubá. De 16 a 20 de dezembro de 2018, percorri igrejas, cartórios, bibliotecas, arquivo municipal, escolas, museu, e tive conversas com 
historiadoras e historiadores locais. Conversas essas que já havia iniciado e continuaram depois por telefone e comunicadores instantâneos.

Antes de ir a Ubá, telefonei para a pesquisadora feminista Fernanda Carneiro, que vive no Rio de Janeiro, amiga de Sueli Carneiro há muitos anos. "Procure Fernanda Carneiro, a família dela também é de Minas, e ela andou pesquisando a história do sobrenome", recomendou Sueli. Apesar de não saber a cidade de origem da família de Fernanda nas Minas Gerais, escrevi para ela contando da pesquisa. Que surpresa saber que Fernanda nasceu exatamente em Ubá. Além de me dar algumas informações sobre a cidade e sua família, Fernanda me colocou em contato com Helder Carneiro, seu irmão, professor de artes e pesquisador. Além de conversar comigo por telefone antes da viagem, Helder me recebeu em Ubá, caminhou comigo pela cidade, promoveu um encontro com três historiadores da cidade e me colocou em contato com José do Carmo Araújo, presidente do Instituto ReAfrica de Memória do Negro e do Índio, doutor em história, estudioso de África e tradições mineiras, que havia sido professor da Universidade Federal de Viçosa.

Além de me encontrar em Juiz de Fora, cidade sede do Instituto, e me acompanhar na chegada a Ubá, José do Carmo me levou a bibliotecas; ao arquivo municipal, onde me apresentou a coordenadora do local; a cartórios; igrejas; ao museu que havia sido uma das fazendas da família fundadora da cidade. Recomendou-me bibliografias, enviou pelo correio cópias de livros que não consegui encontrar, presenteou-me com seu livro sobre os povos bantos (ARAÚJO, 2015).

Em uma primeira visita a cada um desses lugares, recolhi materiais sobre a cidade e sua população negra, sem nada específico sobre a família de Sueli Carneiro. Depois de Ubá, fui às cidades de Guidoval e Rodeiro. E, no livro número 1 da Paróquia São Sebastião, de Rodeiro, restaurado depois de uma enchente, estava o registro de casamento dos avós paternos de Sueli Carneiro, na folha 29:

Aos 20 de setembro de um mil novecentos e treze, na Paróquia São Sebastião (...) receberam-se em matrimônio Horacio Gaivota Carneiro e Olympia Luiza Alexandrina.

Ele com 20 anos de idade. Filho de Maria Gaivota.

Ela com 17 anos de idade. Filha de Alexandre Martins da Costa e Luiza Josepha de Araújo.

Sueli Carneiro nunca tinha sequer ouvido o nome de Maria Gaivota, de Alexandre ou Luiza. Na volta a São Paulo, com certidões nas mãos, Sueli Carneiro me convidou para ir à casa de sua tia Nadir, entregar cópias dos documentos a ela. Um almoço mineiro para 
30 pessoas, com irmãs, irmãos, primos, sobrinhos de Sueli Carneiro nos aguardava, todo mundo interessado em ouvir sobre os documentos encontrados, ocasião em que pude, finalmente, entrevistar tia Nadir. Quando perguntei sobre seus avós, ela me contou detalhes de uma mulher velha, que falava pouco, e cuidara sozinha dos dois filhos, Horácio e Agostino, e da filha Coleta, que também nunca se casou. Mas ficou chateada por não se lembrar do nome da avó de que tanto gostava. Quando mostrei a certidão de casamento, e falei "Maria Gaivotta", seus olhos se iluminaram: "Esse era o nome da minha avó! Maria Gaivotta era minha avó".

Nadir me contou que, quando nova, Maria Gaivotta havia trabalhado nas casas de donos de fazendas como empregada doméstica. Riu ao narrar o que Maria e uma colega fizeram certa vez, com agulha e linha, ao papagaio que a patroa deixava na cozinha para repetir as conversas das pretas. A única coisa que o bicho repetia depois era: " $\mathrm{Cu}$ cosido, sinhá! Cu cosido!”. Nadir ainda gosta da vingança.

Do avô paterno, Nadir nunca ouviu falar. "Minha avó é do tempo dos escravos. Não tinha isso de marido. E os filhos também não falavam de pai”, conta. A informação adiantada por ela, de que Maria Gaivotta fora uma mulher escravizada, só pode ser confirmada a muitos quilômetros dali, depois de saber seu local de nascimento, na certidão de Horácio, seu filho.

No primeiro cartório de Ubá, assim como no da vizinha Guidoval, os nascimentos começaram a ser registrados em 1889; no de Rodeiro, em 1913. Na Paróquia São Sebastião, de Rodeiro, os livros começam em 1911. Como os avós de Sueli Carneiro nasceram naquele distrito, segundo o registro de casamento, a maior probabilidade seria encontrar ocorrência de batismo ou casamento na Paróquia São Januário, de Ubá, que guarda informações desde 1842. Mas não havia registros lá. A certidão de nascimento de seu avô estava no cartório de Ubá:

Aos vinte e dois dias do mez de outubro do anno de mil oitocentos e noventa e um, neste distrito de Paz da Parochia de São Januário de Ubá, Município de mesmo nome, Estado de Minas Gerais, compareceu em meu cartório José Bernardino Fernandes e perante as testemunhas: Honorio Januario Carneiro e Luiz Gonçalves Fontes, ambos negociantes e residentes nesta Parochia e declarou que no dia dezesseis do corrente mez e anno, às nove horas da noite, no corrego Alegre desta Freguesia, nasceu uma creança do sexo masculino, que deve chamar-se HORÁCIO, filho natural de Maria Gaivotta, cozinheira, residente nesta Freguesia, natural de Grão Mogol, filha legítima de Manoel Gaivotta e sua mulher, esta fallecida. 
Grão Mogol é uma cidade no Norte de Minas Gerais fundada por garimpeiros em busca de diamantes. De meados do século XVIII ao início do XIX, a exploração das pedras era clandestina. Umas das possíveis explicações para seu nome é que dos roubos, trapaças e brigas teria nascido um Grande Amargor, contraído depois para Grão Mogol. Outra versão é que o fundador do Império persa Mogol, que existiu no século XVI, chamado pelos portugueses de Grão-mogol, possuía um diamante de 793 quilates, comparável aos encontrados naquela região de Minas (PARRELA, 2009).

A historiadora Ivana Parrela, professora da Universidade Federal de Minas Gerais, pesquisa os arquivos de Grão Mogol há mais de 20 anos. Foi ela quem me deu muitas informações sobre a região, além de me presentear com seu livro (PARRELA, 2009) E empreender o esforço generoso necessário a encontrar o registro de batismo da bisavó de Sueli Carneiro:

Maria, parda, nascida a 15 de junho de 1856 no Burity. Filha legítima de Manoel Gaivotta Costa e de Josepha Maria de Jesus. Padrinho Gonçalo de Azevedo Ferreira. Madrinha Joanna Cardozo de Sá

Não se sabe sobre as condições em que nasceu e viveu Maria Gaivotta. Mas pelas certidões de batismo e nascimento pode-se aferir que ela e seu pai, Manoel, saíram de Grão Mogol, entre 1856 e 1891, e chegaram a Ubá. No período, este foi um fluxo migratório frequente para negras e negros escravizados.

Em 1768, a coroa portuguesa teve notícias da descoberta de diamantes na Serra de Santo Antônio de Itacambiraçu, mais tarde conhecida como município de Grão Mogol. A exploração de diamantes na região aconteceu em variados formatos, por homens livres ou escravizados, até a metade do século XIX. Antes de 1850, a cidade chegou a ter 40 mil habitantes. Depois disso passou à média de 15 mil pessoas, que mantém até hoje (PARRELA, 2009).

Muitas pessoas negras enriqueceram no garimpo e compraram a própria liberdade. Outras resistiram de muitos modos, incluindo a criação de quilombos na região. Hoje, existem mais de 80 comunidades quilombolas na bacia do Jequitinhonha. Buriti do Meio, por exemplo, foi fundada por Eusébio Gramacho, um negro que saiu de Grão Mogol e iniciou a comunidade quilombola certificada pela Fundação Palmares em 2004, que atualmente tem perto de 700 pessoas.

Na segunda metade do século XIX, a extração de diamantes na região se torna inviável. A tecnologia disponível não dava conta das dificuldades de sua extração na 
região. No mesmo período, crescia a mineração em território africano, com diamantes e outros minérios acessíveis com mais facilidade. No Brasil, a produção cafeeira aumenta em todo o Sudeste. No café estava o dinheiro e a necessidade de mão de obra.

Entre 1855 e 1873, 6.562 negras e negros escravizados chegaram a Ubá, comprados de outras regiões de Minas Gerais. No mesmo período, 261 foram vendidos e por isso saíram de Grão Mogol (MARTINS, R., 1994). Se Maria e Manoel Gaivotta fossem pretos livres, como já era livre a maior parte da população negra nesse período, dificilmente se deslocariam no fluxo da venda de pessoas escravizadas. A possibilidade de perder a liberdade saindo do território em que eram reconhecidos como forros era grande e eles saberiam disso. É provável que tenham sido vendidos do garimpo para uma fazenda de café.

A forma como conheci a professora Ivana merece ser relatada. Em maio de 2019, participei do I Encontro Paulista de Patrimônio Histórico-Documental, apresentando o trabalho Memória negra: os documentos relativos à escravização e ao pós-abolição são mesmo escassos?. Ao relatar a jornada de pesquisa sobre os antepassados de Sueli Carneiro, e mencionar Grão Mogol, Jean Camoleze, doutorando em Ciência da Informação na UNESP/Marília, mencionou uma especialista em arquivologia, professora da UFMG, que pesquisava a região de Grão Mogol. Colocou-me em contato com Ivana e passamos a ter trocas de mensagens frequentes, chegamos a almoçar juntas em São Paulo, no final de 2019, quando aprendi muito sobre a história e os arquivos da região.

Voltando à certidão de nascimento de Horácio, avô paterno de Sueli Carneiro, não há sobrenome na criança, nem nome do pai. O sobrenome Carneiro aparece uma única vez: em uma das testemunhas. Por que a criança carregaria o nome de uma testemunha de seu nascimento? A hipótese mais óbvia, reproduzida no senso comum, é de que pessoas escravizadas levavam o sobrenome de seus senhores. Mas, em 1891, três anos depois da assinatura da Lei Áurea, nem Maria nem Horácio eram escravizados, apesar de as relações de servidão permanecerem fortes naquela região até pelo menos a metade do século $\mathrm{XX}$. $\mathrm{E}$ a testemunha, Honorio Januario Carneiro, apesar de herdeiro de terras e membro da família mais poderosa da cidade, de origem rural, era comerciante, como se sabe pela certidão e pelo relato de pessoas da região.

Fernanda Carneiro, a pesquisadora feminista que vive no Rio de Janeiro, amiga de Sueli Carneiro, irmã de Helder, é bisneta de Honorio Januario Carneiro, o mesmo que aparece na certidão de nascimento do avô de Sueli como testemunha.

Fernanda conta que Honorio, seu bisavô, tinha uma loja de chapéus no centro de 
Ubá e era um homem reconhecido por sua bondade e honestidade. Apesar disso, é provável que honrasse a tradição familiar, regional, por que não dizer nacional, de gerar filhos bastardos em mulheres negras. Fernanda afirma que o filho de Honorio, Domiciano Carneiro, seu avô, conhecido como Neném Carneiro, teve filhos fora do casamento e todo mundo sabia. Compartilhou o trecho de um livro com histórias da família, organizado por ela:

Homens da elite eram livres. Mentalidade da ordem patriarcal. Em Minas, lugar conhecido por uma cultura de dissimulação - não convém lembrar agora, nos escreveu Drummond sobre este jeito mineiro - parece que este segredo, caso revelado, iria trazer constrangimentos indesejáveis. $O$ afeto e os laços sociais camuflavam as relações vividas sob segredo, ainda mais quando geravam filhos. É sabido que no século XVIII e XIX, homens brancos tinham filhos naturais com negras e os legítimos com as esposas (CARNEIRO, F., 2001).

O historiador José da Conceição Araújo afirma que quando um homem branco de família tradicional tinha filhos fora do casamento, principalmente crianças negras, era comum que fosse padrinho ou testemunha do nascimento para justificar o vínculo que mantinha com a criança.

Importante notar que, antes do ano de 1916, as Ordenações Filipinas regiam o direito civil brasileiro. Ou seja, valiam as determinações medievais da Igreja Católica, que classificavam filhos como legítimos e ilegítimos. Somente o casamento na Igreja poderia garantir a legitimidade de um filho. Crianças nascidas fora do casamento eclesiástico eram consideradas "frutos do pecado sexual da fornicação" e não podiam ser batizadas ou registradas com o nome do pai (ZARIAS, 2010). Dentre os ilegítimos, havia ainda a subcategoria espúria, dos chamados filhos incestuosos e adulterinos.

Apenas um monarca poderia conceder a crianças bastardas, nascidas fora do casamento, uma carta de legitimação a pedido do pai. Mas uma decisão do Supremo Tribunal Federal, publicada em 1874, reitera que, nem em caso de um filho legitimado por carta, se o pai tivesse outros filhos legítimos, o bastardo teria direito a herança. "O reconhecimento do pai não pode mudar a qualidade dos filhos e destruir as relações e efeitos de direito que dela resultam", registra a decisão. “(...) como pretender-se que uma simples escriptura de reconhecimento paterno tenha mais força do que a santidade do matrimonio?".

Em 1916, o Código Civil, no artigo 358, reafirmou as Ordenações: "os filhos incestuosos e os adulterinos não podem ser reconhecidos". Dos homens, porque filhos 
adulterinos de mulheres eram registrados como legítimos do marido (MONTEIRO, 1990).

Com a Lei 883, de 1949, tornou-se possível reconhecer filhos tidos fora do casamento e os chamados filhos ilegítimos passaram a ter o direito de pleitear o reconhecimento da paternidade e alimentos do pai, caso este não fosse casado. Somente em 1984, com a Lei $\mathrm{n}^{\mathrm{o}} 7.250$, ficou permitido o reconhecimento da paternidade ainda que o genitor fosse casado com outra mulher.

A categoria filho ilegítimo só deixou de existir na Constituição Federal de 1988, que definiu no inciso $6^{\circ}$, parágrafo VII do artigo 227: “Os filhos, havidos ou não da relação do casamento, ou por adoção, terão os mesmos direitos e qualificações, proibidas quaisquer designações discriminatórias relativas à filiação."

Um filho nascido de relação extraconjugal, em 1891, seria considerado espúrio, adulterino, e não poderia ser registrado pelo pai. É provável, portanto, que o avô de Sueli Carneiro, Horácio, seja filho de Honorio Januario Carneiro. Sem poder registrar a criança, considerada ilegítima naquele tempo, esteve no cartório como testemunha e deu o sobrenome a ela.

De Honório, então, viria o sobrenome Carneiro de seu avô, de seu pai, de Sueli e de sua filha. É provável. Como não há pessoas vivas que os tenha conhecido, não se pode confirmar.

Outra hipótese seria o fidalgo, passando em frente ao cartório, generosamente ter se oferecido a testemunhar o nascimento de uma criança preta e ainda lhe emprestar o sobrenome. Quem sabe, uma exceção à realidade comum nas Minas Gerais e também em São Paulo.

José Correia Leite, um dos principais militantes negros de nossa história, nascido na capital paulista em 1900, relata ao escritor Cuti:

Muitas negras moravam com brancos importantes, mas de forma escondida. Não só no Bixiga, em outras partes também, onde o português predominou. Muitas vezes elas eram prejudicadas quando o sujeito morria. Perdia os bens que tinha ajudado a adquirir porque quase sempre não eram casadas. Eu conheci muito caso de indivíduos bem-sucedidos à custa de cozinheiras. Eram mulheres trabalhadoras que não davam a mínima despesa, sequer. Saíam de manhã e voltavam à noite, trazendo coisas (comida, roupa) da casa dos patrões. Ainda havia os favores que seus companheiros precisavam e elas conseguiam. Havia muitos desses casos no Bixiga, que aliás, não foi um bairro só de italiano. Lá morou muito negro também (LEITE, 1992).

O próprio Correia Leite narra seu nascimento à Rua 24 de Maio, quando ali ainda 
era uma zona residencial da pequena São Paulo, sem mencionar a existência de um pai. A mãe, negra doméstica, o deixava de casa em casa, sem muitos cuidados, para poder trabalhar.

Diante de tantas evidências, é forte a hipótese de Horácio Gaivota Carneiro, avô de Sueli Carneiro, ter sido filho adulterino - sem direito a herança ou a reconhecimento - de Honório Januário Carneiro, neto do capitão-mór Antônio Januário Carneiro, fundador da cidade de Ubá.

Em 1815, o capitão-mór, devoto de São Januário, ergueu uma capela para o santo em uma de suas fazendas (VIDIGAL, 1980). Ao redor dela, formou-se um povoado, elevado a cidade em 1857. Antônio Januário Carneiro era um dos cinco filhos de Teresa Maria de Jesus e Silva com o português Antônio Carneiro Flores, nascido em 1732 na região de Braga. O genealogista Pedro Maciel Vidigal afirma que todos os Carneiro do Vale do Rio Doce, que depois se espalharam por outras regiões de Minas Gerais, descendem deste mesmo casal.

Teresa era descendente do paulista Borba Gato. Antônio, apesar do sobrenome de animal e planta e de ter emigrado em um período proeminente da Inquisição, não era cristão novo, de origem judaica. Ao chegar ao Brasil foi nomeado Familiar do Santo Ofício da região do termo de Mariana, e para tal nomeação, era necessário provar que não possuía origem judaica nem moura, em um longo e minucioso processo. Por serem colaboradores laicos da Inquisição, os chamados Familiares possuíam privilégios como a isenção de alguns impostos, além de prestígio social.

Dentre os dez filhos do capitão-mór, cinco mulheres e cinco homens, menciono duas das mulheres: Justina Januária Carneiro e Tereza Januária Carneiro. Justina, mãe de Honório Januário Carneiro, que aparece como testemunha na certidão de nascimento do seu avô. Tereza, mãe de José Cesário de Faria Alvim Filho, personalidade política importante na primeira república, avô de Afonso Arinos de Melo Franco, autor da lei contra a discriminação racial, de 1951, que leva seu nome. E avô também de Maria Amélia de Carvalho Cesário Alvim, mãe de Chico Buarque (VIDIGAL, 1980). Todo Carneiro de Ubá cita Chico como parente distante. 


\section{MULHERES NEGRAS}

Ao falar das mulheres negras na realidade brasileira, estou refletindo sobre mim mesma, saindo do silêncio em que, tenho certeza, está a quase totalidade das mulheres brasileiras, que convivem numa sociedade etnocêntrica, racista e sexista, que usa e abusa de uma linguagem que veio de longe, que exprime conceitos alheios à realidade global do país, além de projetar sobre os demais segmentos populacionais uma série de rótulos e categorizações. Penso aqui como sujeito de minha própria história, com direito à voz e vez. (Helena Theodoro, em Mito e espiritualidade: mulheres negras)

Bianca, menina negra branqueada desde o nome, encontrou nos livros a possibilidade de descobrir mundos. Mas, por mais que os adorasse, sentia falta de ler histórias como as contadas por sua mãe, avós, tias e a vizinhança do conjunto habitacional onde crescera. A conflituosa relação com as patroas, de afeto e solidariedade, mas também de humilhação e injustiça. A criatividade para alimentar os filhos quando não havia dinheiro para o pão. A água puxada do poço para lavar as roupas da freguesia e da família numerosa. As ervas caçadas no mato parar curar e benzer. $\mathrm{O}$ desenraizamento por migrações e despejos. Narrativas tão detalhadas na oralidade, que nada deviam àquelas tão distantes que encontrava na escola e nos livros.

Só no ensino médio teve nas mãos um livro que registrava episódios próximos, tão conhecidos, tanto pelo vivido como pelo que ouviu tantas vezes de vizinhas, no banco de concreto de frente para o campinho, ou da avó, enquanto bordava ponto-cruz. Arminda, professora de língua portuguesa, recomendou um livro que não estava no planejamento: "Quarto de despejo, de Carolina Maria de Jesus. Tem na biblioteca, acho que você vai gostar”. Em um primeiro momento, detestou. E aquela tristeza toda era para estar em livro? Texto tão curto, violento, cada soco no estômago. Deve ter também se incomodado por ver em letras impressas, quase frias, segredos que ouvira em tom sagrado.

Foram necessários ainda alguns anos para a Bianca jovem perceber a importância daquela leitura. Ao acessar a universidade e encontrar gente tão diferente dela, conheceu um cursinho popular do movimento negro, Educafro, onde percebeu uma cumplicidade ainda inexplicável. Com o convite do professor Wellington Andrade, no curso de jornalismo da Faculdade Cásper Líbero, para que escrevesse um texto com uma reflexão 
profunda sobre suas origens, colocou em palavras: Quando me descobri negra. Escrever foi uma possibilidade de dar corpo a percepções difusas. Materializar uma consciência de gênero, raça e classe que não sabia existir em si antes de virar palavra. As perguntas que apareciam de vez em quando desde a infância passaram a ser centrais: de onde veio minha família? Como foram as tantas resistências à escravidão? E os detalhes pós-abolição? Foi simplesmente: boa sorte, podem ir embora para a completa miséria? O que foi feito para a reparação, a emancipação, a cura de tantos traumas? Por que meu cabelo sempre foi chamado de ruim? O que acontece com o meu corpo que sinto até tontura quando vejo meu cabelo solto com tanto volume? Por que em lugares pobres tanta gente se parece comigo e na universidade tão pouca? Com quem posso conversar? Quem já escreveu sobre isso tudo? O que posso ler?

Assombrada pelas histórias não contadas (SHARPE, 2002), eu sentia fome coletiva pelas histórias escondidas (KILOMBA, 2019), e também por repertório teórico que permitisse interpretar e analisar o que via pela janela do apartamento da COHAB; nas voltas de bicicleta pelo Parque Edu Chaves, Jardim Brasil, Vila Sabrina, Vila Medeiros, na periferia Norte de São Paulo; pela janela dos ônibus 1156, 2181, 2127, que percorriam trajetos do extremo ao centro. Nas disciplinas iniciais do curso de ciências sociais da Universidade de São Paulo não encontrou ferramentas que servissem.

A falta de repertório era tamanha que chegou a citar Francisco Weffort em Quando me descobri negra, para falar sobre branqueamento, quando Lélia Gonzalez, Sueli Carneiro, Cida Bento e tantas outras autoras e autores negros tinham escrito mais e melhor sobre o tema, de uma perspectiva que a interessaria e ajudaria muito mais. Mas essas autoras e autores não estavam na bibliografia na escola, nem na universidade, nas disciplinas cursadas no jornalismo e nas ciências sociais; nem do Programa de PósGraduação em Educação da Universidade de São Paulo, onde esteve entre 2009 e 2012.

Só depois de participar de círculos de mulheres negras na Casa de Lua, entre 2013 e 2016, passou a buscar intencionalmente as autoras e autores que tratavam da temática racial. Por mais que participasse das marchas da consciência negra todo 20 de novembro, foi depois das repercussões da Marcha de Mulheres Negras de 2015, que reuniu 50 mil pessoas em Brasília, foi que compreendeu de vez a dimensão e a importância da luta organizada de mulheres negras. E da própria existência de um sujeito político chamado mulheres negras, com características, referenciais e organização próprias.

Há, portanto uma dimensão de identidade, quando falamos em mulheres negras, e uma outra dimensão política. Sobre identidade, Stuart Hall sintetizou em uma entrevista de 
forma muito objetiva o quehavia escrito nas décadas anteriores "Acho que a identidade cultural não é fixa, é sempre híbrida. Mas é justamente por resultar de formações históricas específicas, de histórias e repertórios culturais de enunciação muito específicos, que ela pode constituir um "posicionamento ao qual nós podemos chamar provisoriamente de identidade" (HALL, 2011, p. 409). No sentido tão profundo que Aimé Césaire deu à negritude:

(...) uma maneira de viver a história dentro da história, a história de uma comunidade cuja experiência parece, em verdade, singular, com suas deportações de populações, seus deslocamentos de homens de um continente a outro, suas lembranças distantes, seus restos de cultura assassinados. Como não crer que tudo aquilo que tem sua coerência constituiu um patrimônio? É preciso mais para construir uma identidade? Os cromossomos importam pouco. Mas creio nos arquétipos. Eu creio no valor de tudo aquilo que está enterrado na memória coletiva de nossos povos e mesmo no inconsciente coletivo. Eu não creio que se chegue ao mundo com o cérebro vazio, como se chega de mãos vazias. Eu creio na virtude formadora das experiências seculares acumuladas e dos vividos pelas culturas. (...) Vale dizer que a Negritude, em seu estágio inicial, pode ser definida primeiramente como tomada de consciência da diferença, como memória, como fidelidade e como solidariedade (CESAIRE, 2010, p. 108-109).

Mulheres negras, nesta tese, não diz respeito às que se declaram pretas e pardas ao censo apenas, mas às pretas e pardas que, a partir de memória coletivas, histórias e repertórios culturais comuns, se colocam como sujeito político solidário e insurgente frente às discriminações de raça, gênero e classe.

Jurema Werneck, em artigo publicado em 2009, afirma que as mulheres negras como sujeitos identitários e políticos são fruto de uma articulação de heterogeneidades, resultante de demandas históricas, políticas, culturais, de enfrentamento das condições adversas estabelecidas pela comunicação eurocêntrica, expropriação cultural e racismo. "As mulheres negras não existem", exacerba Jurema Werneck.

Considerando as diferentes trajetórias, origens, agrupamentos, motivações que caracterizam diferenças entre indivíduos chamados mulheres negras, há a construção consciente e intencional de um sujeito político chamado mulher negra, que envolve e evoca as diversas possibilidade de ser mulher negra.

Lélia Gonzalez, intelectual e militante do movimento negro, escreveu ainda no final da década de 1980 sobre a tomada de consciência de mulheres negras, parafraseando Simone de Beauvoir, “(...) a gente nasce preta, mulata, parda, marrom, roxinha etc. Mas 
tornar-se mulher negra é uma conquista" (Gonzalez, 1988). Uma conquista que passa por perceber os entrecruzamentos, ou as exuzilhadas, no termo de Cidinha da Silva (2019), das múltiplas opressões a que estão sujeitas. E também por desembaçar as lentes do racismo à brasileira.

Sueli Carneiro já disse em diversas intervenções públicas e entrevistas que reconheceu a existência deste grupo específico chamado mulheres negras ao ouvir Lélia Gonzalez, em 1982, na Biblioteca Municipal Mário de Andrade, em São Paulo. A experiência foi tão vigorosa, que Sueli teve a sensação de que Lélia podia ouvir sua mente, seu coração, e verbalizar o que ainda não estava organizado racionalmente.

A figura política que compartilhava da luta do homem negro, quem conduzia o debate racial naquele momento, e da mulher branca, a que protagonizava o debate de gênero, mas, que trazia horizonte e luta próprios - a mulher negra - foi apresentada por Lélia Gonzalez.

Além de ser uma intérprete do Brasil, como afirma Raquel Barreto (2018, p. 15), que, no conjunto da obra, retira sujeitos negros da margem e os coloca no centro, analisando o Brasil de uma perspectiva negra, publicou textos sobre gênero e raça essenciais ao desenvolvimento do que hoje se chama feminismo negro brasileiro. Mesmo que Lélia não tenha usado estes termos, ela inaugura uma perspectiva de feminismo negro antes mesmo das conhecidas norte-americanas Angela Davis e Patricia Hill Collins, nos Estados Unidos. Em visita a São Paulo no mês de outubro de 2019, Angela Davis afirmou, em entrevistas e debates, a importância do pensamento original de Lélia Gonzalez sobre as mulheres negras.

Ao positivar aquilo que estigmatizava as mulheres negras, Lélia Gonzalez inverteu a leitura tradicional de figuras como a mãe preta e a mulata, ressaltando a generosidade, o lúdico, a vitalidade de nossos traços culturais e de nossos corpos. Nas palavras de Sueli Carneiro, em entrevista a mim concedida: "Não era necessário abdicar da dança, da graça ou brigar com os corpos coxudos. A possibilidade de protagonismo das mulheres negras passava exatamente por valorizar as características que tantas vezes eram utilizadas para nos subjugar".

As questões levantadas por mulheres negras, que pareciam individuais, foram colocadas de maneira mais ampla por Lélia, que mostrou como a trajetória coletiva de mulheres negras estava marcada por processos de opressão e discriminação. A história das mulheres negras no Brasil, assim como em toda a América Latina e o Caribe, está marcada pelo tráfico de africanos dos séculos XVI a XIX e a escravidão que, no Brasil, durou quase 
400 anos. Além da brutal violência, o contexto da escravidão foi marcado por resistência e luta, fosse nos quilombos, na religiosidade ou nas ações cotidianas de sabotagem e recusa (WERNECK, 2005).

\begin{abstract}
No período pós-abolição, coube à mulher negra arcar com a posição de viga mestra de sua comunidade. Foi o sustento moral e a subsistência dos demais membros da família. Isto significou que seu trabalho físico foi decuplicado, uma vez que era obrigada a se dividir entre o trabalho duro na casa da patroa e as suas obrigações familiares.

(...) Antes de ir para o trabalho, havia que buscar água na bica comum da favela, preparar o mínimo de alimento para os familiares, lavar, passar e distribuir as tarefas das filhas mais velhas no cuidado dos mais novos. Acordar às 3 ou 4 horas da madrugada, para 'adiantar os serviços caseiros' e estar às 7 ou 8 horas na casa da patroa até à noite, após ter servido o jantar e deixado tudo limpo. Nos dias atuais, a situação não é muito diferente para ela (GONZALEZ, 1979).
\end{abstract}

Trinta e um anos depois da publicação do texto de Lélia Gonzalez, em 2008, a cada 100 mulheres negras trabalhadoras no Brasil, 22 eram empregadas domésticas; dez anos antes, eram 48 (IPEA, 2011). Até 2013, as empregadas domésticas não tinham os mesmos direitos trabalhistas de outros profissionais. Graças à luta organizada das trabalhadoras, foram garantidas, ao menos no papel, 44 horas de trabalho semanal, pagamento de hora extra, adicional noturno e seguro-desemprego ${ }^{6}$.

As desigualdades sociais brasileiras estão constituídas, historicamente, a partir de hierarquias nas relações de gênero, raça e classe. $E$ as mulheres negras ocupam ainda hoje a base da pirâmide social brasileira. As piores condições de renda estão entre as famílias chefiadas por mulheres negras: “69\% possuíam, em 2009, renda familiar de até um salário mínimo; valor que, entre as brancas, era de 42,7\%" (IPEA, 2013, p. 30). Outro estudo que viabilizou a desigualdade entre as mulheres foi o Mapa da Violência 2015, que apontou um aumento de 54\% no número de homicídios de mulheres negras entre 2003 e 2013, com uma queda de 9,8\% de homicídios de mulheres brancas no mesmo período (WAISELFISZ, 2015).

O processo de exclusão da mulher negra no Brasil, segundo Lélia Gonzalez, esteve marcado especialmente pelos dois papéis sociais que nos foram atribuídos: domésticas ou mulatas. Domésticas, pela percepção social de que o lugar natural da mulher negra é o de servir, seja como empregada doméstica, faxineira, merendeira. E mulata, pela percepção que coloca a mulher negra na condição de mercadoria a ser consumida sexualmente por

\footnotetext{
${ }^{6}$ Notícia do Portal Brasil, publicada em abril de 2013. Disponível em: <http://www.brasil.gov.br/economia-eemprego/2013/04/nova-lei-do-trabalho-domestico-comeca-a-valer-a-partir-desta-quarta-feira-3>
} 
homens brancos (GONZALEZ, 1979). Por isso, Lélia insistia sempre em dizer, como podese abstrair do conjunto de seus escritos (GONZALEZ, 2018) e segundo afirma Sueli Carneiro, que o marcador fundamental para mulheres negras é o racial.

Mas, se é verdade que a trajetória das mulheres negras brasileiras está marcada pelo evento abominavelmente violento e traumático do sequestro em África, da travessia forçada do Atlântico e da escravização na América, é também verdade que a história das mulheres negras brasileiras começa muito antes da colonização europeia.

\section{Mulheres negras antes e apesar do colonialismo}

Em terras africanas/formaram-se impérios de destemidas mulheres/ de grandes guerreiras.

Rainhas soberanas/ divindades da beleza nobreza, sabedoria e poder.

Rainha Makeda, Etiópia/Rainha Nzinga, de Angola, Rainha Yaa Asantewaa/ no Reino Ashanti de Gana

Candaces de nossa história,/ mulheres negras, Candaces de nossa história,/ negras africanas.

(Letra de Mulheres Negras, de Célia Santos e Estela Carvalho, repertório do Carnaval 2011 do Ilú Obá de

Como afirma Leda Maria Martins (1997), nosso corpo, individual e coletivamente, foi violado pelos emblemas e códigos linguísticos, filosóficos, religiosos, culturais europeus; o eurocentrismo desconsiderou a história das civilizações e culturas africanos.

No entanto, a colonização da África, a transmigração para as Américas, o sistema escravocrata e a divisão do continente africano em guetos europeus não conseguiram apagar no corpo/ corpus africano e de origem africana os signos culturais, textuais e toda a complexa constituição simbólica, fundadores de sua alteridade, de suas culturas, de sua diversidade étnica, linguística, de suas civilizações e história (MARTINS, L., 1997, p. 25). 
A mitologia iorubá, presente em terreiros e roças de candomblé nagô, espalhadas pelo Brasil desde o século XIX, permite apreender partes da complexa constituição simbólica de civilizações africanas. Os iorubás ou nagôs constituem um grupo étnicolinguísticos da África Ocidental, em países ao Sul do Saara, em sua maioria na Nigéria, compondo $21 \%$ da população do país, mas também no Benim, Togo e Serra Leoa. Na mitologia iorubá, as mulheres, têm atributos equivalentes aos dos homens, que em nada se parecem com uma possível inferioridade ou constituição como subprodutos dos homens, como nas culturas judaico-cristãs. Há constante antagonismo e desconfiança entre homens e mulheres, em que um sabe que o outro pode submetê-lo (CARNEIRO; CURY, 1982). Essa disputa se expressava na organização de homens e mulheres em sociedades secretas específicas a cada um. Geledés são exemplos dessas organizações secretas femininas de origem iorubana, que existiram pelo menos desde o século XVIII.

Conforme explicam Sueli Carneiro e Cristiane Cury (1982):

O universo místico nagô, do qual o candomblé é remanescente, se estrutura como várias outras mitologias no princípio da sexualidade. É da interação dinâmica e conflituosa entre pares de contrários que tudo é gerado. Assim, a terra (àiyé) e o além (órum) funcionam segundo essa dinâmica, expressados pelo homem e pela mulher: ele enquanto princípio genitor masculino, ligado ao órum, e ela como a terra grande, ventre reprodutor, princípio genitor feminino. Essa união, que é a garantia da continuidade de tudo, não se dá harmonicamente, e os conflitos que são relatados nos mitos expressam sempre a luta entre os poderes masculino versus feminino em disputa pelo controle do mundo. Discutir, portanto, a mulher no candomblé nos remete imediatamente às figuras míticas femininas que, entendemos, compõem um perfil da compreensão que o sistema mítico do candomblé possui da condição feminina.

Iyá mi, a mãe ancestral, é a divindade mítica feminina que guarda o poder e o segredo da criação. É a representação máxima do poder feminino. Por isso muito temida. Aspectos de Iyá mi podem ser encontrados nos orixás femininos cultuados no candomblé nagô, como Oxum, Iemanjá, Iansã, Obá, Ewá e Nanã.

Cada um desses orixás femininos possui qualidades complexas que não cabem nas dicotomias que costumam qualificar as mulheres, em uma perspectiva eurocêntrica, como boa/ má; santa/puta. Oxum, deusa da fertilidade, da beleza, da riqueza, das águas doces, pode trazer esterilidade, enchentes e outros aspectos negativos dos poderes que exerce. A mãe doce e suave, quando irada, é destruidora. Oxum, como as águas calmas, é considerada 
por muitos traiçoeira. Nas palavras de Sueli Carneiro e Cristiane Cury: "Ela encanta os homens e os submete".

Um dos títulos de Oxum é o de Ialodê. Diz respeito à liderança política feminina, ao poder feminino exercido nas cidades. Segundo Jurema Werneck “(...) representante das mulheres, aquela que fala por todas e participa de instâncias de poder" (WERNECK, 2006). Nas práticas do candomblé, da umbanda, da cultura e da música popular brasileira, é costume cantar a Oxum, no ritmo ijexá, depois de saudá-la dizendo Ora yèyé ô:

\section{Oro mi má \\ Oro mi maió \\ Oro mi maió \\ Yabadoo Yeyeo}

No bloco afro Ilú Obá de Min, além das dançarinas e dançarinos fazerem uma releitura dos movimentos arredondados da dança do orixá Oxum, de suas mãos evocarem o espelho, instrumento do orixá, a bateria também se movimenta evocando no corpo as características dela.

No naipe das alfaias, tambor típico do maracatu, ao tocarem o couro e o aro do instrumento com leveza, as integrantes reproduzem nas pernas o ritmo da dança do ijexá. Ao final, apoiam as baquetas no coro do tambor e movimentam as mãos como se tomassem banho em um rio ou cachoeira. Compreendendo este comportamento expressivo como performance, é possível afirmar, conforme defende Diana Taylor (2013, p. 17) que se trata de uma episteme, um modo de conhecer, ao ativar conhecimentos por meio da ação incorporada, da agência cultural e das escolhas. Há, então, a ativação de uma memória coletiva, como será elaborado adiante.

Soma-se aos movimentos espontâneos e aos reproduzidos, aquilo que se compartilha nas rodas de conversa e vídeos de formação do naipe, quando as mestras do grupo, as mulheres do axé - iniciadas e frequentadoras do candomblé - e as que têm maior experiência na dança dos orixás, explicam às demais o sentido de cada movimento. Reconhecer os atributos de Oxum em cada uma das integrantes, além de honrar e saudar o orixá, é também um ensinamento de auto-cuidado e valorização da beleza e do poder de cada uma das integrantes, em seus diferentes corpos, formatos e tons de pele.

O bloco afro Ilú Obá de Min, fundado por Beth Beli, Girlei Miranda e Adriana Aragão, em 2004, havia sido precedido pelo bloco Oriashé, de 1988 (SOUZA, V., 2009, p. 37-41). Em livre tradução do iorubá o nome do bloco significa "Mãos femininas que tocam 
tambor para o rei Xangô”. O bloco está dividido em naipes: da bateria, alfaia, djembê tambor africano, xequerê - instrumento feito de cabaça e contas, agogô - de ferro; e também corpo de dança, balé de pernaltas e cantoras. No carnaval 2020, apenas na bateria há 400 mulheres, no bloco todo, quase 450 pessoas. Homens só podem participar dos naipes da dança e de pernaltas.

Além de apresentações do carnaval, o Ilú Obá, como é conhecido, é uma associação sem fins lucrativos, que tem como base o trabalho com as culturas de matriz africana, afrobrasileira e a mulher, com o objetivo de preservar e divulgar a cultura negra no Brasil e o fortalecimento das mulheres negras.

Os cortejos da sexta-feira e do domingo de Carnaval marcam a presença do bloco na cidade, bem como a chamada lavagem da mentira da abolição na rua 13 de maio, na data de assinatura da Lei Áurea, e a participação em inúmeros atos e manifestações de rua. O culto aos orixás é referência do bloco, assim como as manifestações culturais de maracatu, batuque, coco, jongo, entre outras (ILÚ OBÁ DE MIN, 2020). Atualmente, o bloco é coordenado por Beth Beli, tem direção musical de Beth Beli e Mazé Cintra, e outras 20 mulheres na coordenação do bloco. Mazé Cintra e Teresa Telles coordenam o naipe das alfaias.

No carnaval, a cada ano, uma mulher, ou grupo de mulheres, é homenageada. Em um dos ensaios de 2018, quando as mulheres quilombolas foram homenageadas, Beth Beli explicou que o Ilú Obá de Min levava para as ruas da cidade de São Paulo aquilo que a escola e os livros não ensinavam. Dentre as homenageadas estão: Rainha Nzinga, de Matamba e Angola que viveu entre 1581 e 1663; Leci Brandão, cantora, compositora, deputada e madrinha do bloco; Raquel Trindade, artista plástica e filha do poeta negro Solano Trindade; Carolina Maria de Jesus, escritora negra que teve seu livro Quarto de Despejo traduzido em mais de 30 línguas; Elza Soares, cantora e compositora negra; mulheres quilombolas; ativistas do movimento negro das décadas de 1980 a 90; a cirandeira Lia de Itamaracá; Nega Duda, sambadeira do recôncavo baiano, também coordenadora das cantoras do Ilú Obá de Min, e cuidadora espiritual do grupo. As mãos de Nega Duda fizeram o fundamento religioso do Ilú Obá. 
Imagem 5: A regente, criadora e diretora do bloco afro Ilú Obá de Min, Beth Beli, no centro do círculo formado por integrantes do bloco, mestras e mestres da cultura popular (de branco) e público, no domingo de carnaval, em 2020.

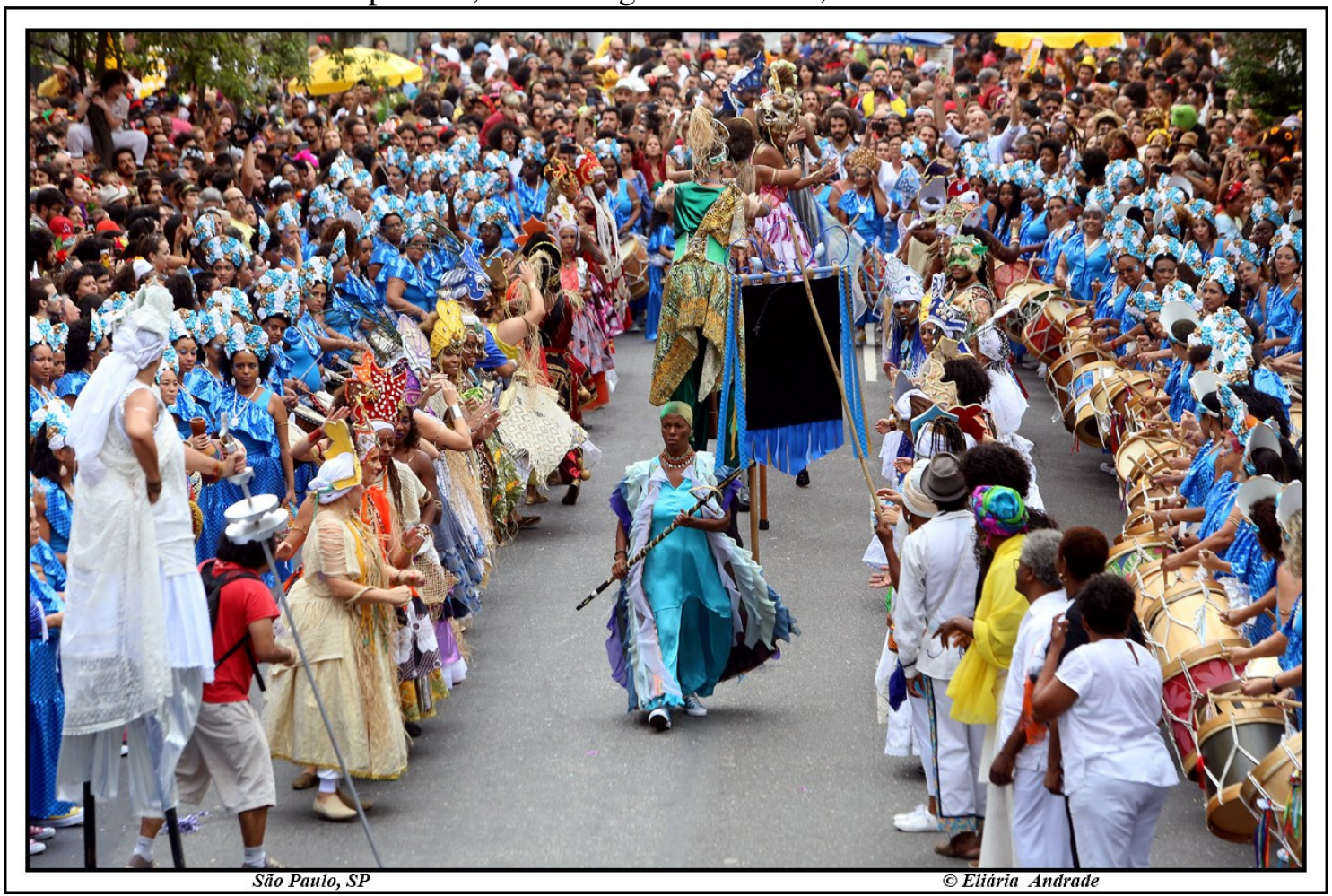

Fonte: Perfil de Facebook de Eliária Andrade

Imagem 6: Nega Duda, cantora e uma das coordenadoras do bloco afro Ilú Obá de Min, abraça Beth Beli ao final do cortejo da sexta feira, no carnaval 2020, em homenagem a Lia de Itamaracá

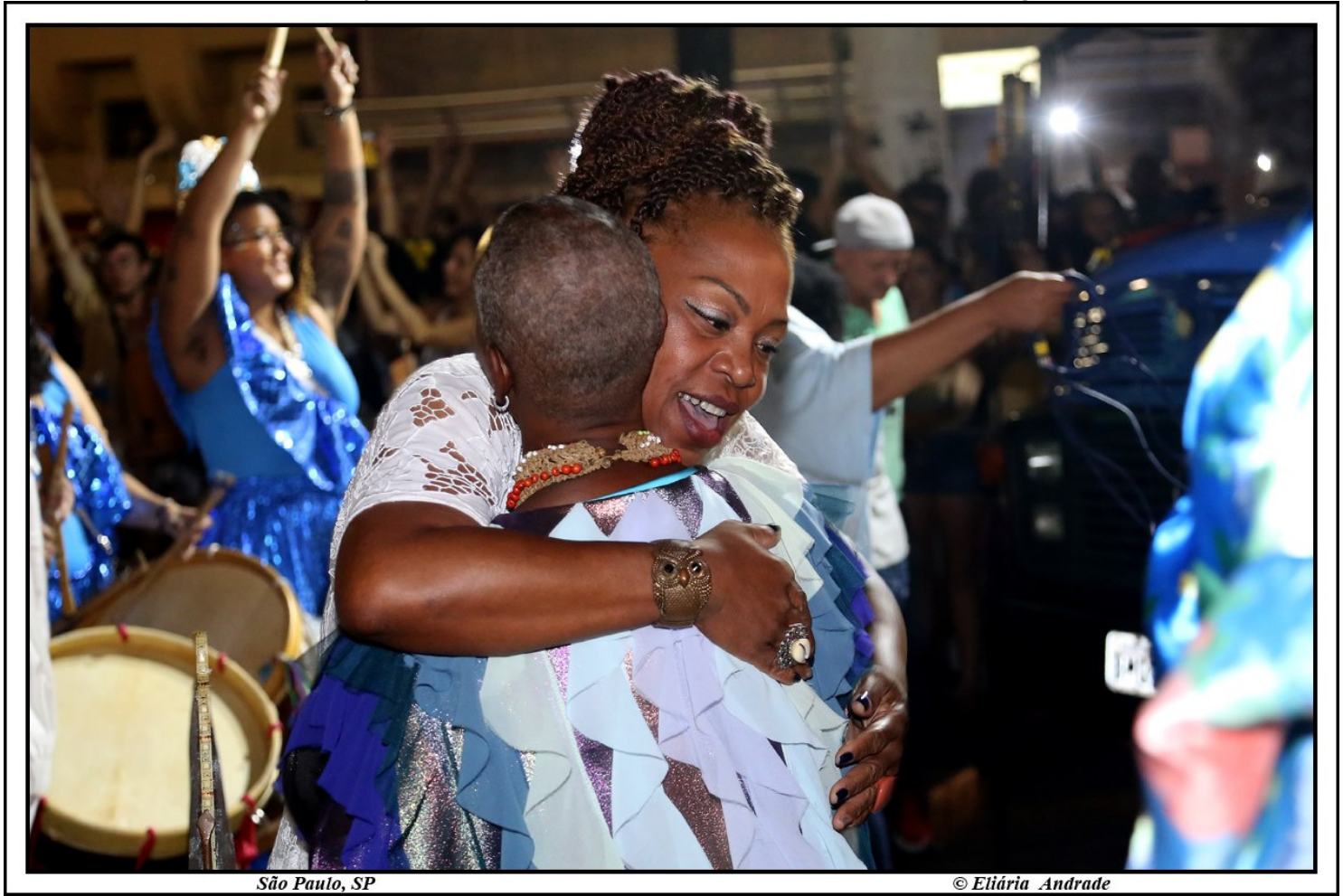

Fonte: Perfil de Facebook de Eliária Andrade 
Imagem 7: O naipe das alfaias em círculo, com a mestra Mazé Cintra e os instrumentos ao centro, em concentração na Praça da República, antes do cortejo em homenagem às mulheres quilombolas, em 2017

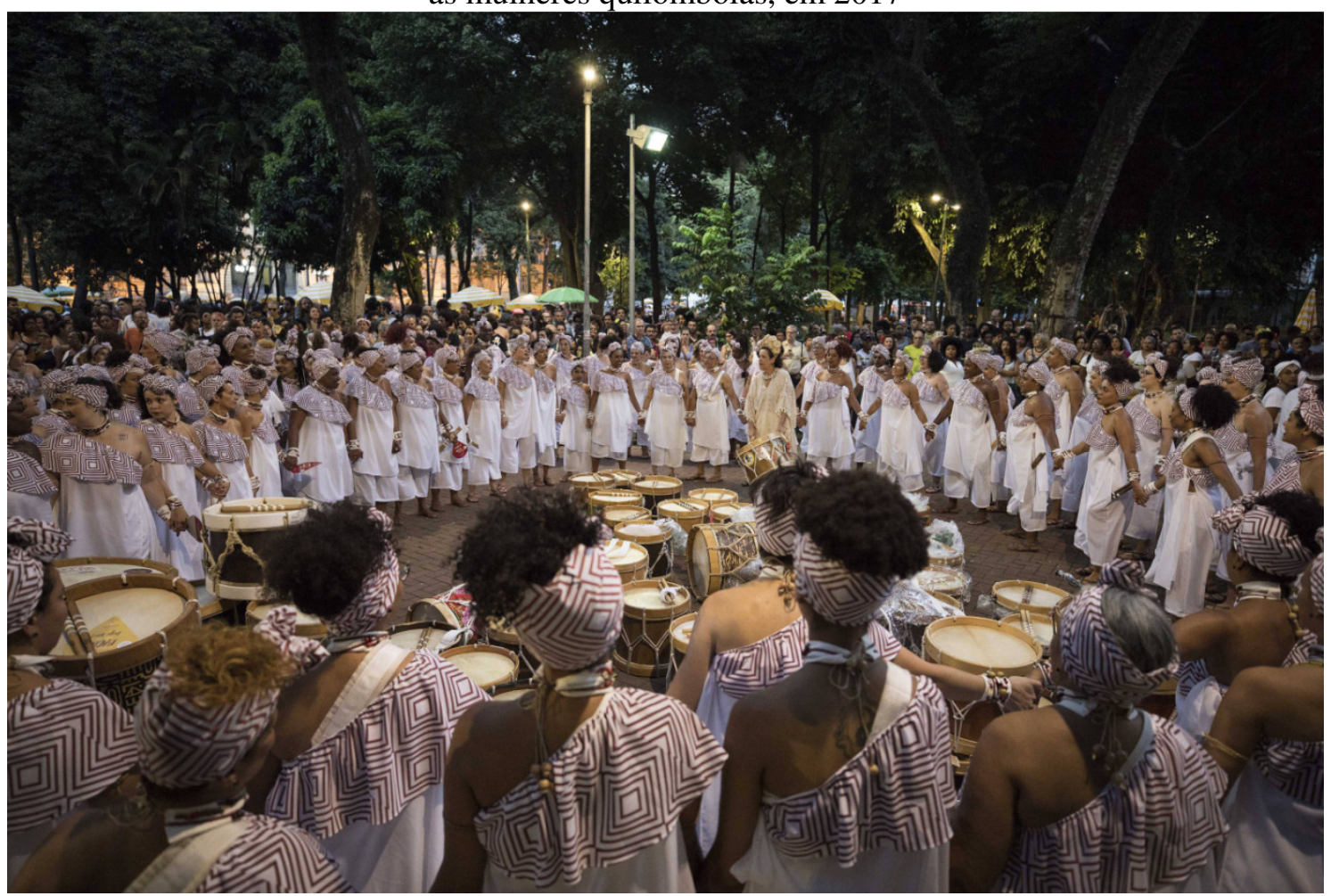

Fonte: Folha de S. Paulo. Disponível em:

$<$ https://www1.folha.uol.com.br/colunas/monicabergamo/2019/02/criei-um-exercito-de-armasharmonicas-diz-presidente-do-bloco-ilu-oba-de-min.shtml>.

Iansã, deusa guerreira do vento, dos raios e das tempestades, afasta os espíritos dos mortos. Pode assumir a forma de búfalo, para proteger os filhos, ou de borboleta, para voar aonde quiser, sem ser machucada por ninguém. Nos cortejos do Ilú Obá de Min, Christiane Gomes, uma das coordenadoras do naipe da dança, Mafalda Pequenino, coordenadora de pernaltas, e outras mulheres que representam Iansã, o fazem no meio da bateria, depois da saudação Eparrei, Oyá!

Primeiro, ao toque de um adahun, e do canto:

\section{Oiá têtê Oiá têtê Oiá}

Oiá têtê Oiá balê, Oiá têtê Aiabá

Depois, no ritmo quebra-prato:

Ela é zambi, ela é zambi, ela é muchaxé

A insubordinação feminina é ritualizada e celebrada em Iansã, e também em Obá, orixá guerreira que carrega um escudo, uma espada e, ao dançar, protege a orelha que perdeu por amor. Mais forte que muitos orixás masculinos, se atribui a Obá a chefia das sociedades secretas Geledé (CARNEIRO; CURY, 1982). 
Nanã, orixá feminino da vida e da morte, não aceita que homens participem de seus mistérios. No Ilú Obá, o ferro do agogô, símbolo do orixá masculino Ogum, não é tocado para Nanã e é respeitosamente segurado com as mãos para trás de corpos curvados em homenagem à anciã. Por confrontar o poder feminino e reafirmar a igualdade e os poderes das mulheres, assim como Oxum, Nanã também pode receber o título de ialodê. Deusa do profundo mistério da vida, das águas paradas, da lama, Nanã é o orixá feminino mais velho. Ao final do toque para Nanã, também curvadas, as integrantes da alfaia balançam lentamente as baquetas, de um lado a outro, como Nanã faz para ninar os mortos. Conectadas ao movimento de ninar os próprios ancestrais, não é incomum perceber mulheres chorando no toque para Nanã.

Iemanjá, senhora das águas salgadas, a grande mãe, orixá mais conhecido e cultuado no Brasil, cuida das cabeças de todas as pessoas. No Carnaval 2020, o Ilú Obá de Min, faz homenagem a Lia de Itamaracá, filha de Iemanjá, e por isso esse orixá ganha destaque no cortejo. Além da música dos anos anteriores, Aquiridô ô qui oluwa ôdô é iá quequerê, no toque de um adahun, com a bateria se movimentando para frente e para trás, formando uma grande onda, outras duas músicas foram incorporadas ao xirê, cantos de evocação aos orixás.

Fé lè fé lè, com um toque bravum, pede que o orixá lave com as águas do mar e permita ver, conhecer.

\author{
Fé lè fé lè \\ Yemonjawéokun \\ Yemonjawéokun \\ Ágòfirémòn \\ Ágòfirémòn \\ Ajakáigbaru, igbaru \\ Ó wá e
}

Representantes da dança e pernaltas, ao adentrar o corpo da bateria com sua dança ondulada, testemunham as águas escorrerem dos olhos de tantas mulheres que também se movimentam em ondas ao tocarem seus instrumentos. Transbordamento que segue ao toque do aguerê de Obá, e do canto de que tudo que é feito, é feito nas águas de Iemanjá.

\author{
Kinijekinije l odõ \\ Yemonja o \\ A kota pele gbé \\ Iyáoró mi o
}


As tantas potencialidades humanas presentes nos sistemas de representação dos orixás e das mulheres míticas oferecem vivências e saberes negados pela sociedade patriarcal. $\mathrm{O}$ poder negado às mulheres negras na estrutura social brasileira, é experimentado por essas mulheres no candomblé e em outras religiões de matriz africana, nas manifestações culturais diversas como no bloco Ilú Obá de Min.

(...) elas trabalham, cantam e dançam noite adentro para os seus orixás; assim elas entendem que apesar de Oxalá ser o grande genitor masculino, ele se curva em adobale (gesto que exprime prostrar-se em sinal de reverência) diante de Oxum, o poder genitor feminino. Elas sabem que apesar de Oxalá só poder usar a cor branca, ele coloca nos cabelos a pena vermelha, o ekodidé, em homenagem ao sangue menstrual, símbolo da fertilidade e da concepção. Então percebem que a dominação masculina não se explica pela sua natureza inferior, mas pelo temor $\mathrm{e}$ reconhecimento de suas potencialidades. Descobrem, enfim, que a Virgem Maria e Maria Madalena são forças latentes em cada uma delas, e que não precisam abdicar de sua sexualidade para atingir o reino dos céus. As deusas negras são mães dedicadas e amantes apaixonadas (CARNEIRO; CURY, 1982).

Lélia Gonzalez afirma que a realidade cultural e histórica vivida por mulheres negras em diversas sociedades africanas não era o de subordinação ou discriminação. "Do Egito antigo aos reinos ashanti ou dos yorubá, as mulheres desempenharam papéis sociais tão importantes quanto os dos homens" (GONZALEZ, 2018, p. 363). Em muitas dessas sociedades, o poder político era partilhado. 
Imagem 8: parte do corpo de dança do bloco-afro Ilú Obá de Min. No centro, de vermelho, Christiane Gomes representa Iansã, em seu lado esquerdo, de roxo, Andréia Alves representa Nanã.

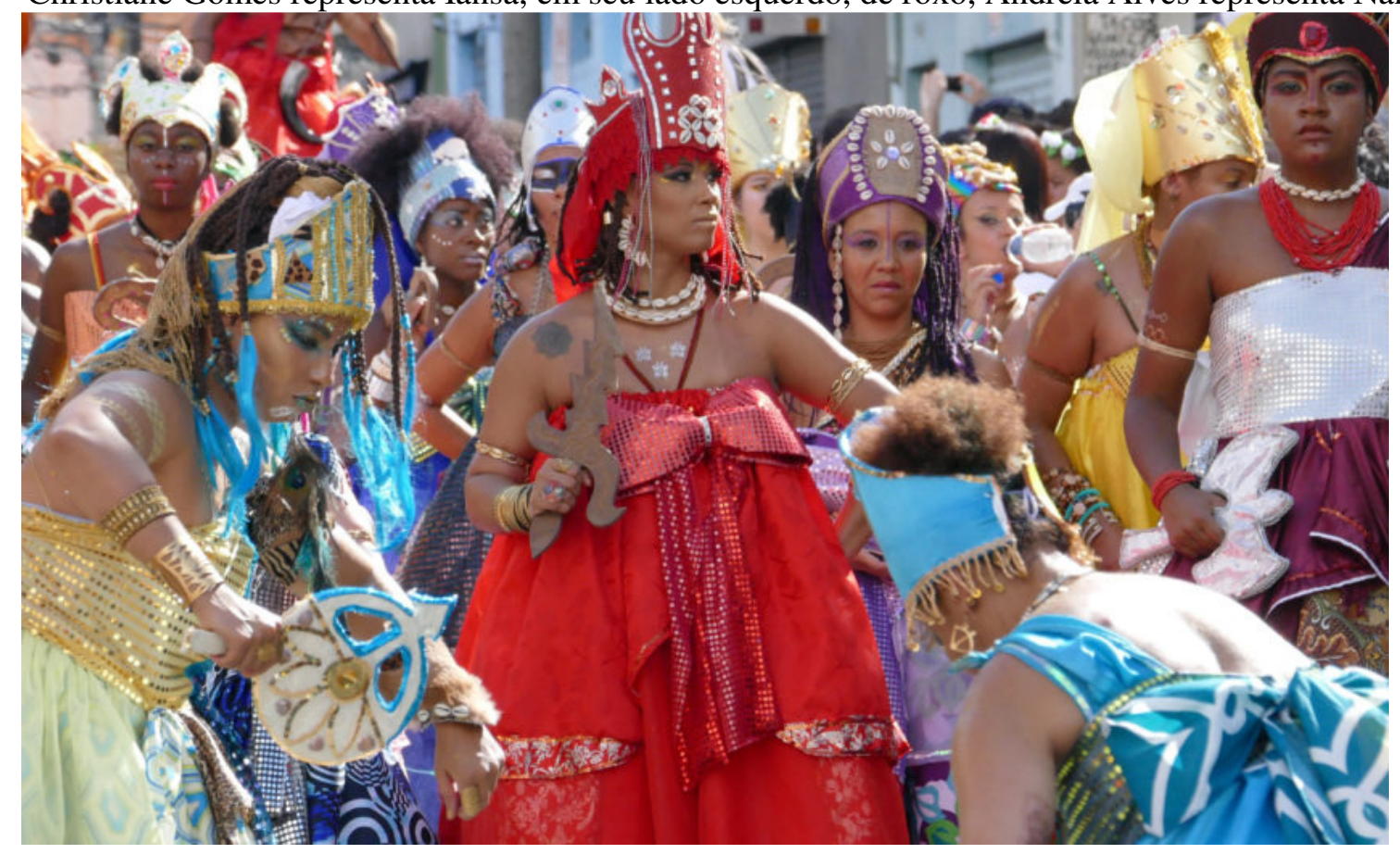

Fonte: Foto de Filipe Araújo / Fotos Públicas

A mitologia iorubá, apesar de só ter chegado ao Brasil no século XIX, é a mais difundida no país. Os povos bantos, de origem na África Central, de países como Angola, Congo e Gabão, apesar da diversidade cultural compartilham o mesmo tronco linguístico e uma única cosmologia. Na tradição banto, a vida é sustentada por um ser supremo - Zambi, Kalunga ou Lessa - que reina sobre o universo. Divindades ligadas às forças da natureza chamadas nkisis, muitas vezes comparados aos orixás, exercem poder sobre os homens e as mulheres. Como exemplo dessas divindades, dentre as femininas, pode-se citar Kisimbi, a grande mãe; deusa de lagos e rios, sereia de águas doces; Dandalunda, de extrema beleza, parentes das kiandas - sereias; Kaiala, divindade do mar e oceanos, reconhecida como útero materno que dá origem a toda a vida. Estima-se que, dentre negras e negros que vieram escravizados ao Brasil de 45 (DALBERT, 2015) a 75\% (CASTRO, 2008) tinha origem banto.

Taata Mutá Imê, sacerdote do candomblé bakongo, nação angola, do Nzó Mutà Lombô ye Kaiongo e a Casa dos Olhos de Tempo, em Salvador, Bahia, ordenou em sua roça de candomblé: "É preciso também escrever sobre os banto. Leia Fu- Kiau, aprenda aqui e conte.” Depois de seis anos jogando búzios com Mutá Imê em São Paulo, fui levada por Pedro, meu filho do meio, à roça de Salvador, para cuidados espirituais. Além dos ebós necessários, as vivências com filhas e filhos de santo, a esteira do barracão, as folhas 
sagradas espalhadas no terreiro e as conversas com Mutá Imê reafirmaram meu compromisso com o candomblé, apesar de não ser iniciada.

Cresci em uma família sem religião, em que minha mãe era kardecista, minha avó materna se dizia católica sem nunca pisar em uma igreja, minha avó paterna era benzedeira mas não gostava que se espalhasse a notícia, meu tios, tias e pai haviam sido frequentadores da umbanda, meu pai me apresentara o candomblé, meu tio Haroldo me ensinara saudações a orixás e algumas tradições do candomblé. Na infância, pedi para frequentar a igreja católica com as crianças da $\mathrm{COHAB}$ que fariam a primeira comunhão e ganhei o apelido familiar de beatinha, carregado de reprovação. Conheci a teologia da libertação, as missas afro, a liturgia católica e, mais velha, fui catequista por cinco anos. Na universidade, me afastei da igreja e chorei na madrugada com uma amiga lamentando a falta que uma prática espiritual me fazia. No estágio em uma grande editora, uma colega de trabalho que exercera generosamente papel de mentora e orientadora permitiu que eu a acompanhasse na umbanda que frequentava.

Quando ressoou o primeiro toque de atabaque, comecei a chorar. Do início ao fim daquela gira estive arrepiada com a força que circulava no lugar, emocionada com a frase que martelava em minha cabeça: "mesmo que tenham tentado destruir de tantas formas, por tantos séculos, aqui estão esses toques de tambor, aqui está minha ancestralidade”. A gira entrou madrugada adentro, mas, quando acabou, fiz questão de telefonar para minha mãe: “A senhora diz que eu não gosto de nada. Eu amei os atabaques da umbanda!". A resposta, inesperada: "Eu sabia que você ia gostar. Você é igualzinha à sua avó.” E só então descobri que minha avó materna que se dizia católica guardava o segredo de já ter frequentado a umbanda e depois o candomblé, por muitos anos. Por que tinham escondido a informação de mim? Por que não me foi apresentada esta possibilidade de encontro a quem se sentia tão sem lugar? Parece-me que o projeto de branqueamento da minha família em relação a mim não se deu apenas na escolha do nome em italiano.

Frequentei a casa na Freguesia do Ó por alguns anos, até ser mãe do Lucas, meu primeiro filho, e mudar a rotina a ponto de não conseguir mais me dedicar a compromissos noturnos. E só depois de parir minha terceira filha, Cecília, joguei búzios com Mutá Imê pela primeira vez, seguindo a indicação de meu terapeuta junguiano.

Chegar à Casa dos Olhos do Tempo foi ainda mais especial por estar como acompanhante de meu filho Pedro. Aos oito anos de idade, meu filho de pele mais escura, o único que se percebe e é percebido em alguns ambientes como uma criança negra, passou por vivências que eu tive apenas depois de adulta. Ao ouvir ensinamentos de Mutá Imê, 
corri a pegar papel e caneta para tomar notas e não perder detalhes importantes. "Nunca mais faça isso. Se fosse no tempo de minha mãe de santo, você nunca mais ouviria nada." Como, então, lembrar para contar depois? Como compreender o que não pode e o que deve ser narrado? Eu não teria respostas diretas e verbais, como nunca tive de minhas avós, de tia Guida, enquanto me ensinava a leitura das cartas, nem mesmo de Sueli Carneiro, quando se tratava dos temas mais sutis.

Em uma das vezes em que cheguei à casa de tia Guida, irmã de meu pai, costureira moradora da Vila Medeiros, que me ensinou a lidar com as cartas, estava orgulhosa de mim por ter estudado muito cada um dos significados que ela me ensinara no encontro anterior. Ela então embaralhou as cartas e pediu que eu lesse para ela. Muito segura, fui dizendo as palavras soltas que havia decorado sobre cada carta, sem me conectar a nenhuma camada mais sutil de nossas interações, a nenhuma percepção do que o conjunto daquelas cartas poderia narrar de maneira mais ampla. Tomei tanta bronca! Comparadas apenas às da vó Polu, minha avó materna; à de Taata Mutá Imê e às de Sueli Carneiro. Outra camada da matriz africana que pude vivenciar.

Imagem 9: Taata Mutá Imê, no barracão do Nzó Mutà Lombô ye Kaiongo e a Casa dos Olhos de Tempo, na parede, representações dos nkisis Kisimbi e Mutalambô.

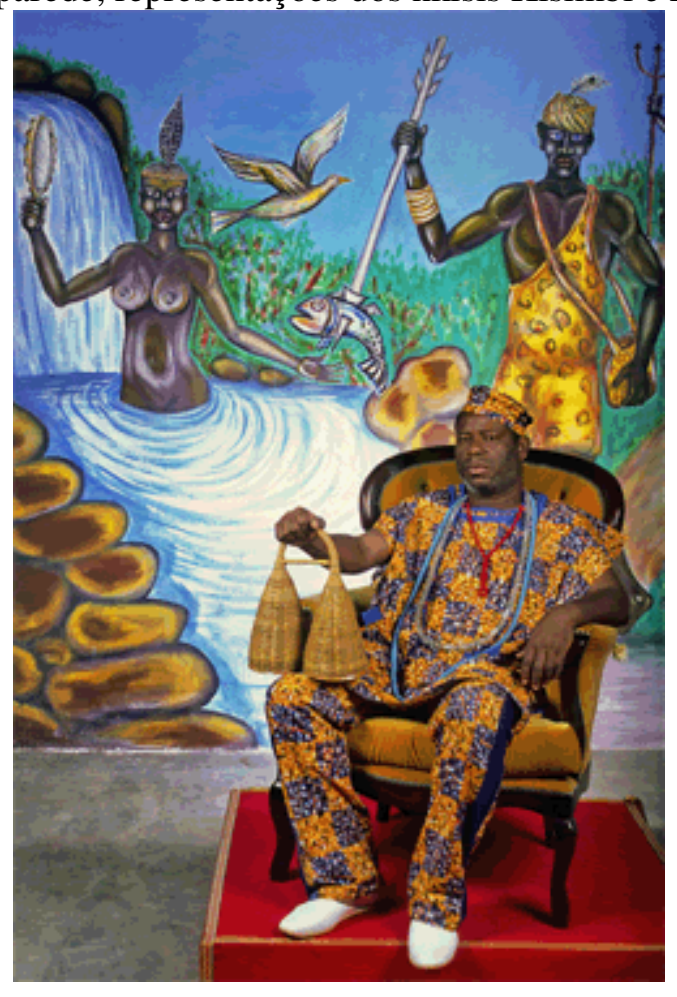

Fonte: Foto de Aristides Alves / Divulgação 
Meses depois de ir à roça de Taata Mutá Imê, recebi o convite para participar de uma roda de conversa sobre conhecimento de terreiro. Com uma experiência tão reduzida, perguntei ao Mutá Imê como responder ao convite. "Vá e jogue duro! Confie em você, na sua capacidade intelectual junto à sua sabedoria ancestral." Conectada a esta orientação e às leituras da filosofia banto de Bunseki Fu-Kiau, esboço uma outra afirmação de matrizafricana sobre a mulher.

Até 2019, só havia encontrado escritos de Fu-Kiau em inglês ou francês, o que dificultava ter certeza de estar compreendendo os escritos complexos de uma filosofia que reconheço como familiar, mas que nunca tinha lido ou ouvido de forma sistematizada e como filosofia. Estaria minha compreensão equivocada por conta da tradução? E então Tiganá Santos, em sua tese de doutorado (SANTOS, T., 2019, p. 197), traduziu do inglês a principal obra de Fu-Kiau, A filosofia africana dos bantu-kongo, para português, mantendo os termos em língua kikongo e interpretou muito do que ela condensa à luz de entrevistas e outras pesquisas feitas por ele.

Na tradução, são listados os fundamentos culturais bantu entre os kongo:

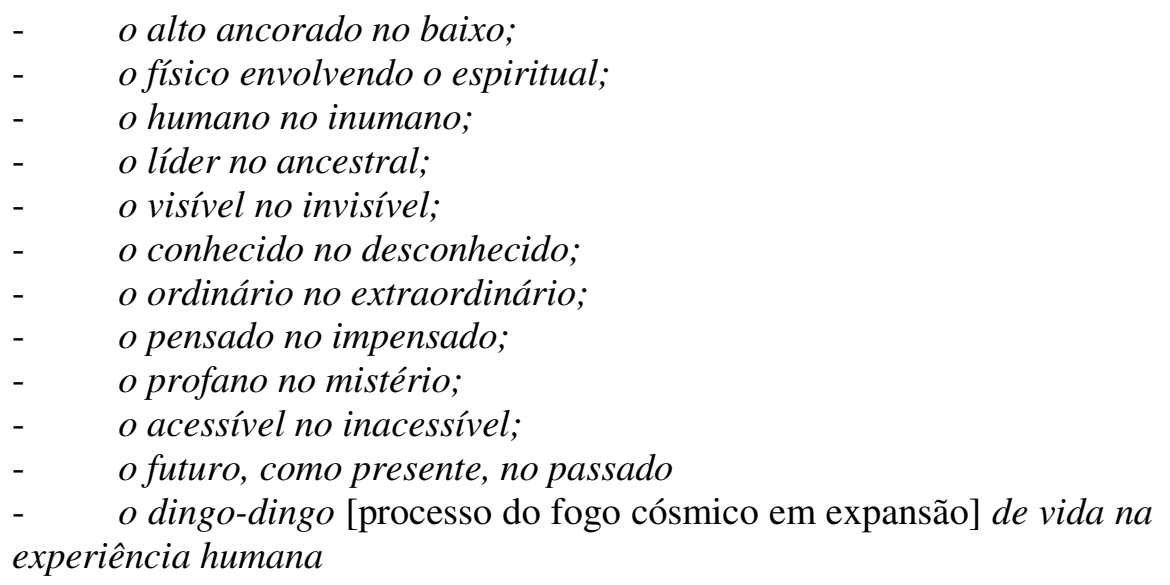

Tais fundamentos podem ser observados em experiências e escritos de mulheres negras como será analisado no capítulo 5. Além deles, Fu-Kiau reúne 53 kinganas, aqui compreendidos como aforismas, espécie de máximas que exprimem de forma concisa um pensamento filosófico. Nas palavras de Fu-Kiau, conforme a tradução de Tiganá Santos: "são princípios, teorias, armazéns de conhecimento, livretos informações gravadas e, sobretudo, tem 'force de loi', força de lei, com circunstâncias jurídicas” (Fu-KIAU, 1973 apud SANTOS, T., 2019, p. 207). 
O kingana de número 2, Kanda diasâla nsâng n’kènto ka ditûmbukanga ko, em kikongo, é traduzido como "O feminino é a vida (Deus) em e ao redor de nós". Fu-Kiau explica:

\begin{abstract}
Enquanto houver um 'rebento' feminino dentro da comunidade, ela não poderá ser aniquilada. A presença de uma mulher na comunidade é o símbolo da continuidade da vida nessa comunidade, e, ao contrário, a ausência é o símbolo de seu término.
\end{abstract}

Além da interpretação óbvia de que do útero das mulheres cis nascem os descendentes de uma comunidade, que permitem sua continuidade, podemos abstrair a informação de que as mulheres são as guardiãs daqui que é necessário para que uma comunidade exista: "terra e pessoas", segundo indica um outro aforisma. Tal afirmação dialoga com a influência que mulheres negras e das classes populares exerceram na formulação de políticas públicas de habitação no Brasil contemporâneo, em que a posse do imóvel é da mulher, ou o Bolsa Família, que repassa o dinheiro às mulheres. Experiências de homens que não repassam recursos à companheira, aos filhos e à comunidade respaldou a tomada de decisão de mulheres organizadas, que tanto dialoga com a filosofia banto. Empírica e filosoficamente, as mulheres são as guardiãs da vida, das pessoas e das comunidades.

$\mathrm{Na}$ língua kikongo, kanda significa comunidade, mas também possui o sentido de família. Família que extrapola a consanguinidade. Família composta por mortos, vivos e também estrangeiros que passem a ser reconhecidos como parte da comunidade. Segundo afirma Tiganá Santos,

o estrangeiro (nzenza) não é uma fatalidade ou destino, é reversível para ser ou retrátil, deixando de ser. É também por tudo isso que uma das sentenças do bakongo nega a hostilidade da comunidade/ sistema/ família/ certo mundo/ sociedade ao estranho. Prevê-se sua presença na comunidade. Uma família ou comunidade é um registro de informações, saberes, imaginários e compartilha, desse modo, uma simbologia comum a um livro (nkanda) Cada comunidade é um livro escrito (asonama) por pessoas, pela cultura, pelo tempo, em conjuntura de diversidade, ratificando o que diz um(a) kingina (SANTOS, T., 2019, p. 189).

Essa vida comunitária, como se verá adiante, é mencionada em diversos escritos de mulheres negras. Muitas vezes fala-se do navio negreiro como a quebra de possibilidade de vínculos consanguíneos que levou mulheres e homens negros a formarem comunidades de acordo com outras conexões, como as famílias de santo do candomblé, por exemplo. Mas, 
de acordo com a filosofia banto, conforme interpretada por Fu-Kiau, antes e apesar da colonização, uma noção ampliada de família/ comunidade marca a organização desses povos, que configuram a ancestralidade da maior parte das pessoas negras no Brasil.

Mas seria equivocado supor que a comunidade é central apenas para os povos banto. Allan da Rosa, angoleiro, historiador e escritor, lista em seu Pedagoginga, autonomia e mocambagem (2019), elementos característicos de uma cosmovisão africana que ultrapassa fronteiras geográficas e poderiam ser generalizados como constantes em filosofias vividas pelas mais diversas etnias. Ele o faz, a partir da leitura de Eduardo David de Oliveira (2003), apresentando pilares que se mantêm fortes apesar do colonialismo e de fluxos migratórios antigos com chineses ou indianos, por exemplo.

Allan da Rosa destaca princípios como: a noção de um universo integrado como teia; a palavra como atributo do preexistente, que promove realizações, transforma o mundo, um veículo primordial do conhecimento que a tudo envolve, adentrando e movendo coisas, lugares e seres; a morte compreendida como parte do processo cíclico da existência, restituição à fonte primordial da vida; a noção de poder como algo vivido coletivamente e a serviço da comunidade; uma concepção de tempo que privilegia o tempo ancestral que serve de base de encontro do destino, a ancestralidade como quem assegura estabilidade e solidariedade do grupo.

Tanto os fundamentos culturais bantu listados por Fu-Kiau e traduzidos por Tiganá Santos (SANTOS, T., 2019) quanto os princípios de uma cosmovisão africana selecionados por Allan da Rosa (2019) possuem traços comuns entre si e com os valores civilizatórios afro-brasileiros sistematizados por Azoilda Loretto da Trindade (2010): circularidade; ancestralidade; oralidade; ludicidade; cooperativismo; musicalidade; corporeidade; religiosidade; memória; axé. Princípios vivenciados por mulheres negras brasileiras, presentes no que escrevem sobre si.

\section{A escravização de mulheres negras no Brasil}

De um reino distante eu vim

Nigéria, Congo, Benin.

Dentro de um porão escuro, atravessei o negro oceano sem fim.

Tudo o que eu tinha eu deixei, em Porto Novo embarquei. Sete voltas na árvore do esquecimento eu dei. Mas guardei na alma a minha bagagem, 
memórias de força e coragem.

Palavra, oração, ancestrais, tambores, sabores e cores demais.

Uma tal riqueza nunca se viu.

Toda essa beleza veio de navio. A África Negra foi recriada no Brasil.

- Mas então o que é que você trouxe?

- Eu trouxe alegria, trouxe a santeria, trouxe a fantasia pra brincar o carnaval.

- Diga lá, o que é que você trouxe?

- Eu trouxe a poesia, eu trouxe a folia trouxe a bateria, pra tocar no carnaval.

(Negro Mar, de Estela Carvalho. Repertório do Carnaval de 2010, do Ilú Obá De Min)

Esperança Garcia, mulher negra escravizada no sertão do Piauí no século XVIII, nos mostra que havia muitas diferenças entre as que compartilhavam a condição de escravizadas. Não há dados sobre que porcentagem da população brasileira era alfabetizada neste período, mas, o primeiro censo do país, de 1872 , registrava que $82,3 \%$ da população brasileira era analfabeta (FERRARO, 2004, p. 182). Cem anos antes, em 1770, Esperança Garcia escrevera uma carta de próprio punho endereçada ao então governador da província do Piauí denunciando as violências a que era submetida antes de fugir e viver fora do cativeiro por, pelo menos, oito anos (SILVA et al., 2013). 
Imagem 10: carta escrita por Esperança Garcia em 1770 para relatar as violências a que era submetida como escravizada ao governador do Piauí

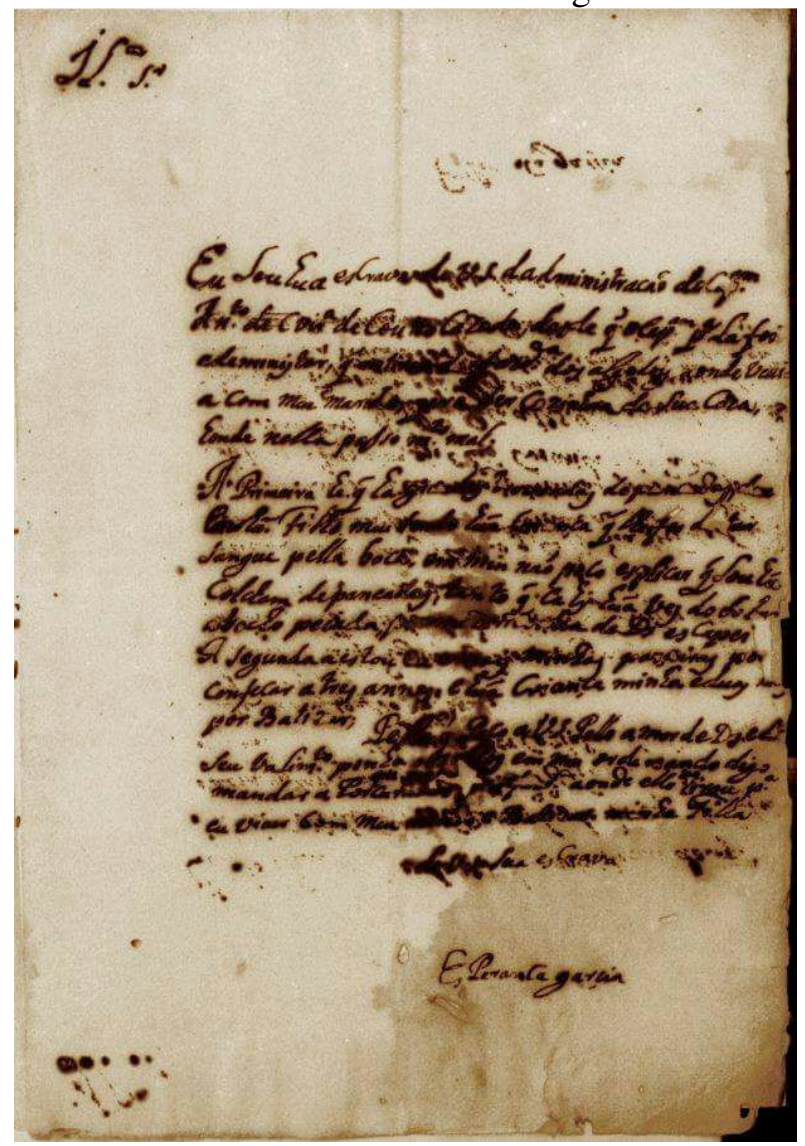

Fonte: Projeto "Carta de Esperança Garcia". Disponível em: $<$ http://culturadigital.br/cartaesperancagarcia/a-carta/>.

Distante dos estereótipos atribuídos às negras escravizadas, Esperança era alfabetizada, tinha uma família composta por marido e filho, e não aceitava a situação a que estava submetida, fazendo da palavra escrita um instrumento de reivindicação política. Com a linguagem atualizada por pesquisadores da Universidade Federal do Piauí, Esperança escreveu:

Eu sou uma escrava de V.S.a administração de Capitão Antonio Vieira de Couto, casada. Desde que o Capitão lá foi administrar, que me tirou da Fazenda dos Algodões, aonde vivia com meu marido, para ser cozinheira de sua casa, onde nela passo tão mal. A primeira é que há grandes trovoadas de pancadas em um filho nem, sendo uma criança que lhe fez extrair sangue pela boca; em mim não poço explicar que sou um colchão de pancadas, tanto que caí uma vez do sobrado abaixo, peada, por misericórdia de Deus escapei. A segunda estou eu e mais minhas parceiras por confessar a três anos. E uma criança minha e duas mais por batizar. Pelo que peço a V.S. pelo amor de Deus e do seu valimento, ponha aos olhos em mim, ordenando ao Procurador que mande para a fazenda aonde ele me tirou para eu viver com meu marido e batizar minha filha. De V.Sa. sua escrava, Esperança Garcia (SILVA et al., 2013). 
Nas palavras de Esperança, há reivindicações individuais e também coletivas, de porta-voz de um grupo de mulheres escravizadas. Quantas Esperanças não existiram dentre as mulheres negras sequestradas em território africano e traficadas para o Brasil em condições subumanas? Estima-se que entre 1560 e 1855, 5.848.265, ou seja, quase 6 milhões de pessoas, tenham sido embarcadas nos portos africanos para serem escravizadas no Brasil. Aproximadamente 748.550 morreram no trajeto. Desembarcam aqui, cerca de 5.099.815 pessoas (ELTIS; RICHARDSON, 2010).

Quadro 2: tráfico negreiro com destino ao Brasil

\begin{tabular}{|c|c|c|}
\hline & Embarcaram com destino ao Brasil & Desembarcaram em portos brasileiros \\
\hline $1501-1600$ & 154.191 & 112.738 \\
\hline $1601-1700$ & 1.011 .192 & 1.991 .362 \\
\hline $1701-1800$ & 2.213 .003 & 2.143 .678 \\
\hline $1801-1900$ & 2.469 .879 & 5.099 .815 \\
\hline Total & 5.848 .265 & \\
\hline
\end{tabular}

Fonte: ELTIS; RICHARDSON, 2010

As "zonas de caça” dessas pessoas (NASCIMENTO, B., 2008, p. 73), por portugueses ou africanos que se aliavam aos dominadores em guerras ou sequestros, variou ao longo destes quase quatro séculos: no XVI acontecia na Guiné e Costa da Mina, com navios saindo dos portos ao longo do litoral do Daomé; do século XVII em diante mais ao Sul da costa Africana, a partir dos portos de Luanda, Benguela e Cabinda (FAUSTO, 1997, p. 51), regiões litorâneas e de sertão que hoje compõem as repúblicas do Senegal, Gâmbia, Serra Leoa, Libéria, Gana, Togo, Benin, Nigéria, Camarões, Guiné Equatorial, Gabão, Congo-Brazzaville e Angola (LOPES, 2004, p. 656). No século XVIII, angolanas e angolanos foram trazidos em maior número. De Moçambique e Madagascar, vieram poucas pessoas, no início do século XIX. Vinham pessoas traficadas dos dois principais grupos étnicos africanos: sudaneses e bantos, em suas variadas nações: iorubás, jejes, tapas, hauçás ou malês (sudaneses); angolas, benguelas, monjolos, moçambiques (bantos). "Durante esse 
tempo mais de dez gerações de africanos viveram em sobressalto, temendo pela liberdade e pela vida, suas e de seus próximos”, nos lembra Nei Lopes (2004, p. 656).

Imagem 11: mapa com as rotas do tráfico negreiro transatlântico para o Brasil

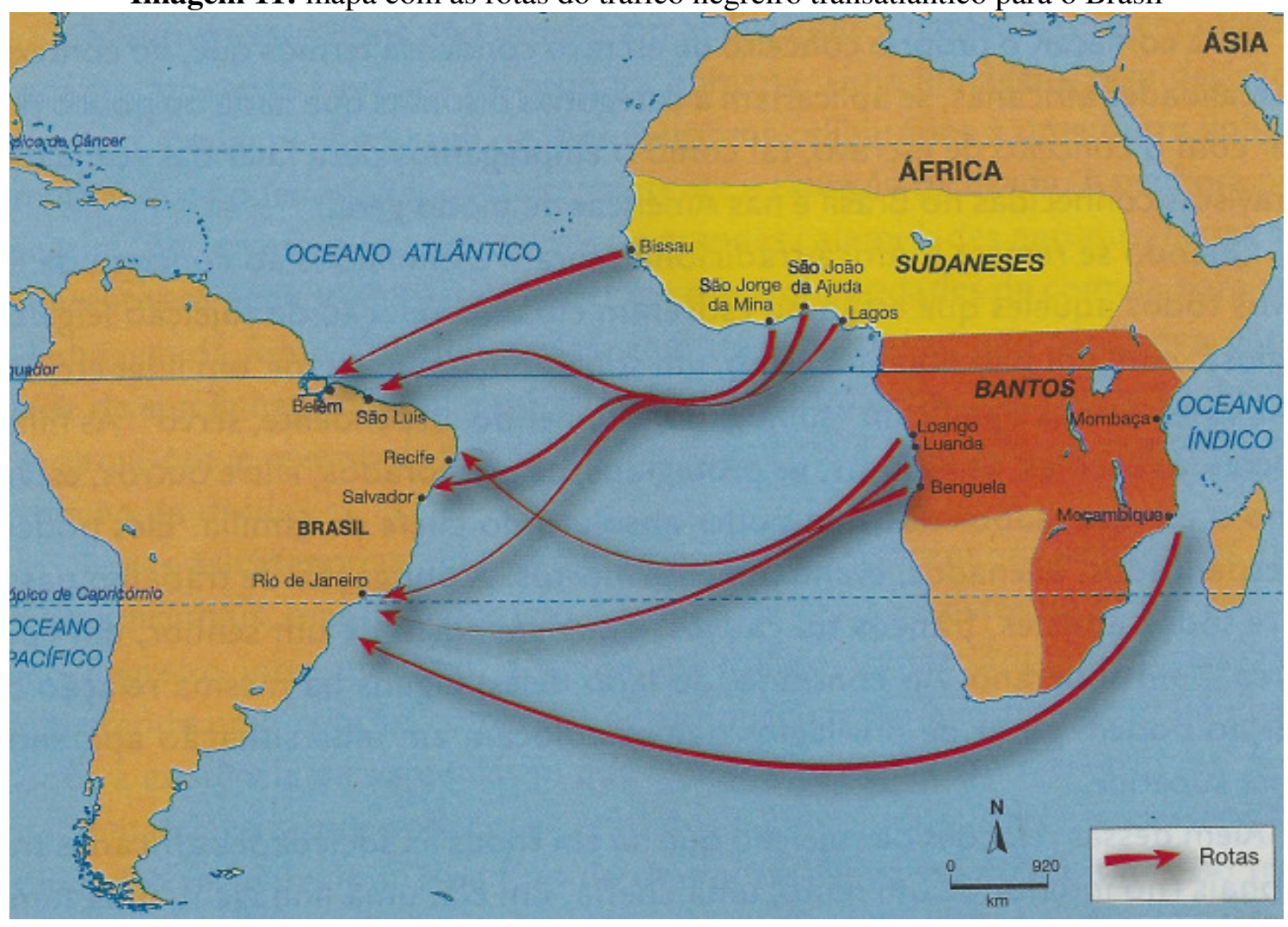

Fonte: MUNANGA, Kabengele, 2009, p. 87

Tornou-se comum que se repita no Brasil de Bolsonaro que africanos escravizavam africanos muito antes da chegada dos europeus, na tentativa de relativizar ou apagar o tráfico transatlântico. É verdade que havia disputas entre os diferentes povos africanos e que escravizar prisioneiros de guerra era uma realidade, assim como havia estrutura de comércio de escravos. Mas nada que se compare aos números, à violência e ao modo definitivo do tráfico transatlântico.

Simone Weil (1979), ao estudar operários franceses, formulou as noções de enraizamento e desenraizamento. Enraizamento, para a autora, é a necessidade mais importante e desconhecida da alma humana, diz respeito à participação real, ativa e natural na existência de uma coletividade que conservava vivos tesouros do passado e expectativas de futuro. Ecléa Bosi utiliza as noções de Weil para pensar a cultura popular brasileira, sob o ponto de vista das migrações. 
Como pensar em cultura popular em um país de migrantes? O migrante perde a paisagem natal, a roça, as águas, as matas, a caça, a lenha, os animais, a casa, os vizinhos, as festas, a sua maneira de vestir, o entoado nativo de falar, de viver, de louvas a seu Deus... Suas múltiplas raízes se partem. Na cidade sua fala é chamada 'código restrito' por linguistas, seu jeito de viver, 'carência cultural', sua religião crendice ou folclore. Seria mais justo pensar a cultura de um povo migrante em termos de desenraizamento (Bosi, 2003, p. 177).

O que dizer então sobre a violência do sequestro e tráfico de seres humanos em território africano para a escravidão nas Américas? Como já foi mencionado, diversos estudos afirmam a impossibilidade de se preservarem laços étnicos nos navios negreiros e na experiência de escravidão no novo mundo. Mas, apesar do desenraizamento, há cultura.

Nas palavras de Ecléa sobre migrantes: "Não buscar o que se perdeu, as raízes já foram arrancadas, mas procurar o que se pode nascer nessa terra de erosão" (Bosi, 2003, p. 177). Antes mesmo da chegada significativa de pesquisadoras e pesquisadores negros à pós-graduação, pesquisadores brancos como Hebe Mattos e João José Reis já mostravam como laços e identificações de grupo foram reinventados entre pessoas escravizadas a partir também de elementos culturais comuns, especialmente a mesma matriz linguística. E muito nasceu na brutal erosão.

Tornar-se escravo africano na América foi uma experiência dolorosa de ressocialização em condições adversas, que já há algum tempo tem merecido a atenção da historiografia. Pode produzir, por vezes, a descoberta ou construção de uma identidade africana impossível e impensável na própria África (unindo malês e iorubás na Bahia) ou permitindo a autodescoberta de uma identidade linguística e cultural entre os bantos do Rio de Janeiro. No nível individual, entretanto, o que parece ter prevalecido é a mediação da comunidade escrava já estabelecida na ressocialização, como escravo, do recém chegado (MATTOS, 2013, p. $153)$.

Por mais que pessoas traficadas tenham sido arrancadas de sua terra e de seus laços familiares e comunitários, elas compartilhavam elementos comuns com as que estavam na mesma situação, o que possibilitava a construção de uma identidade africana que provavelmente não existia em África. "Essa identidade se constituía cotidianamente pela interação entre pessoas da mesma nação, que lançavam mão de um universo simbólico e institucional comum - muito dele 'descoberto' como comum no Brasil - para estabelecer fronteiras grupais" (REIS, J., 2003, p. 310).

A historiadora Juliana Barretos Farias, em sua tese de doutorado, registra como pretas e pretos mina dominavam as atividades de ganho, compravam a própria alforria, 
organizavam irmandades e associações de apoio mútuo, casamentos. Analisando negras e negros comerciantes no Mercado da Candelária, no Rio de Janeiro oitocentista, Juliana observou que havia prosperiedade econômica entre eles, até mesmo pequenos escravistas. Adaptadas ao mundo branco, forjavam uma identidade mina a partir de experiências vividas e forjadas no Rio de Janeiro (FARIAS, 2012, p. 275-276).

No contato com quem estava no Brasil havia mais tempo, novas identidades foram forjadas. Conectadas, é evidente, à vida anterior à escravidão delas mesmas ou de suas ancestrais africanas. Mais uma vez, um olhar para essas mulheres africanas como se fossem homogêneas é o olhar do colonizador sobre elas. Há inúmeras evidências de que, mesmo em situação de escravidão, africanas e africanos se recusavam a ser tratados como um conjunto indiferenciado.

Cada um tinha uma história própria que fundamentava e fortalecia a identificação grupal no exílio, mas aqui as fronteiras identitárias foram ampliadas, congregando grupos diversos em novas nações africanas. Assim fazendo, os africanos que reinventavam a África no Brasil, mas não o fizeram de modo arbitrário. As nações tinham suas genealogias enraizadas em regiões específicas na África, onde se nutriam de elementos culturais comuns àqueles que sob elas se abrigavam, sobretudo a língua (REIS, J., 2003, p. 311).

O livro de João José Reis sobre a Revolta dos Malês, articulada na Bahia por africanos escravizados em 1835, permite visualizar como as identidades grupais no período da escravidão se moldavam de forma diferente para quem nascia no Brasil, em condições de escravidão, de quem era capturado em África e escravizado aqui. Crioulos e cabras, como eram chamados os negros escravos nascidos no Brasil, tinham o português como primeira língua, assim como os colonizadores, e não raras vezes estavam enredados em relações de paternalismo que traziam alguns benefícios raramente acessados por quem era traficado de África, como poder cultivar uma roça própria, por exemplo, até maior facilidade na conquista da alforria.

Constituiu-se então alguma cumplicidade entre o escravo nacional e o senhor e, por extensão, entre o afro-baiano e o baiano branco. As relações sociais do cotidiano estavam enredadas em uma ideologia paternalista que, embora não excluísse totalmente o africano, sobretudo o ladino, envolvia com maior força os escravos e libertos brasileiros (...). Era um sistema de controle e dominação de classe. A classe senhorial não exercia o poder apenas na ponta do chicote, mas também mediante o convencimento de que o mundo da escravidão oferecia ao escravo - e a 
uns mais do que a outros - segurança e mesmo algum espaço de barganha (REIS, J., 2003, p. 322).

Não à toa, entre escravizadas e escravizados que participaram da Revolta dos Malês, assim como nas mais de 20 revoltas de escravizados na Bahia anteriores a 1835, não havia nenhum revoltoso nascido no Brasil (REIS, J., 2003, p. 320). Dentre os 36 africanos interrogados ou mencionados nos depoimentos sobre a Revolta havia duas mulheres: Edum, de etnia nagô (iorubá), africana liberta; e Zampara, cujo nome cristão era Benta, de etnia haussá (malê), africana liberta (REIS, J., 2003, p. 318). As duas mulheres africanas, mesmo sendo de etnias distintas, encontraram traços comuns na experiência da escravidão e participaram ativamente da articulação da revolta. Não é possível afirmar que as duas soubessem ler ou escrever, mas é importante considerar que a escrita era muito importante dentre os malês, que organizavam grupos de alfabetização entre escravos e libertos. "É realmente impressionante que a experiência da leitura e da escritura disciplinada pudesse interessar tão vivamente a libertos e sobretudo a escravos que, embora cansados do trabalho, sempre arranjavam tempo para se dedicar a elas" (REIS, J., 2003, p. 225).

A personagem principal do romance Um Defeito de Cor, de Ana Maria Gonçalves (2007), Kehinde, nascida na Costa do Daomé e escravizada no Brasil, primeiro em Itaparica, depois em Salvador, foi alfabetizada ainda na infância, apesar da condição de escravizada. Kehinde, Luiza Mahin, teria participado da Revolta dos Malês, passando pela cadeia, precisando passar períodos fora de Salvador para não correr o risco de ser deportada para África como foi a maioria dos revoltosos. A obra de ficção foi toda constituída a partir de pesquisas em arquivos feitos por Ana Maria Gonçalves, que foi compilando dados de diversas mulheres e homens escravizados para compor a trajetória da personagem.

Uma das histórias contadas por Ana Maria Gonçalves é de Agontimé, rainha do reino do Daomé entre 1789 e 1797 que, depois da morte do marido, foi vendida pelo enteado empossado rei. (VERGER, 1990). No Brasil, Agontimé, conhecida como Maria Jesuína, de etnia mina-jeje, cria a Casa das Minas, em São Luís do Maranhão, onde cultua os voduns da família real do Daomé. Quando seu filho é coroado rei, em 1818, manda buscar a mãe nas Américas, mas essa se recusa a voltar, já que tinha a missão de sacerdotisa, de cuidar dos voduns e de seu povo que atravessou o Atlântico.

Até 1850, quando foi interrompido o Tráfico Negreiro, chegavam pessoas da África constantemente. Os fluxos variaram nos diferentes períodos, como se pode visualizar na tabela 1, apresentada anteriormente. Informações chegavam de África por essas pessoas, 
assim como práticas culturais eram rearticuladas em relação ao que também acontecia lá. Apesar das adaptações e inovações no novo território, fortes vínculos com o passado em África foram mantidos e alimentados. Como escreveu Reis (2003, J., p. 2010), não se trata de procurar resquícios ou sobrevivências com base em uma crença essencialista, mas de buscar compreender as mediações culturais na sociabilidade e nas narrativas dessas mulheres. E mesmo depois de 1850, com a proibição do tráfico negreiro, chegavam pessoas escravizadas clandestinamente aos milhares. Porto de Galinhas, em Pernambuco, tem esse nome porque os navios negreiros, a partir da segunda metade do século XIX, traziam pessoas escravizadas encobertas por cargas de galinhas.

Estima-se que apenas Luiz Gama, rábula negro, reconhecido recentemente como advogado, tenha libertado cerca de 500 pessoas escravizadas ilegalmente no Brasil, chegadas depois da Lei Eusébio de Queiroz. O Patrono da Abolição conquistou a própria liberdade por medida judicial, quando passa a atuar por negras e negros. Em carta a um amigo, sugere que Luisa Mahin, participante da revolta dos Malês, tenha sido sua mãe, nascera livre, mas o pai branco o vendeu como escravizado.

A experiência de ser mulher negra no período escravagista era diferente não só entre as que nasceram no Brasil e as que vieram no tráfico negreiro, mas também entre as escravizadas domésticas, urbanas, das grandes plantações e ganhadeiras entre si, e dentre estas e as negras livres ou forras. É especialmente importante ressaltar essas diferenças para compreender como no período colonial existia uma massa de mulheres negras em condição de subalternidade e invisibilizadas, ao mesmo tempo em que todo o comércio de carnes, peixes, frutas e tecidos de cidades como Salvador e Rio de Janeiro era controlado por mulheres negras que não raramente enriqueciam e exerciam poder político. No mesmo período, por exemplo, Maria Firmina dos Reis, mulher negra livre, escreveu o romance Úrsula, no Maranhão, publicado em 1859, 29 anos antes da abolição. Não há história única das mulheres negras, nem mesmo no período da escravidão.

Nos grandes latifúndios, em sistema de monocultura e escravidão, a mão de obra escravizada era predominantemente masculina, jovem e africana. Apesar de, até metade do século XIX, a escravização no Brasil ser majoritariamente pulverizada entre pequenos proprietários, o modelo plantation sempre foi a face mais visível da escravidão e a mais presente no imaginário social (MATTOS, 2013, p. 134). E mesmo nas grandes fazendas havia diferenciação socioeconômica entre negras e negros. Quanto mais antigo em uma fazenda, especialmente por mais de uma geração, maior a possibilidade de relações familiares estáveis entre pessoas escravizadas e de cultivo da própria roça. 
Há evidências de divisão sexual do trabalho e sobrecarga das mulheres: trabalhadoras da roça como os homens, lavavam e passavam a roupa de seus maridos ou recebiam por isso de outros homens. Apesar disso, a maior parte das mulheres estava mais distantes fisicamente das senzalas, seja porque eram escravizadas domésticas ou porque constituíam família e podiam viver em suas roças (MATTOS, 2013, p. 149). As que eram escravizadas nas grandes propriedades, em menor número que os homens, estavam expostas não só à violência sexual dos senhores, como se verá a seguir, mas também ao dispor sexual de homens negros escravizados.

(...) tem-se por hábito, nas grandes propriedades, reservar uma negra para cada quatro homens; cabe-lhes arranjar-se para compartilharem sossegadamente o fruto dessa concessão... (Debret, 1972 apud Giacomini, 1988, p. 72)

E independentemente da função que a mulher negra ocupasse, fosse nas grandes ou pequenas propriedades, nas casas grandes ou no espaço urbano, ela estava à mercê do senhor como objeto sexual. Concretizados estupros com frequência ou não, a possibilidade de ser solicitada sexualmente estava sempre presente, sem recusa possível (Giacomini, 1988, p. 65).

\begin{abstract}
A sexualidade da escrava aparece para o senhor livre de entraves ou amarras de qualquer ordem, alheia à procriação, às normas morais e à religião, desnuda de toda série de funções que são reservadas às mulheres brancas, para ser apropriada num só aspecto: objeto sexual.

A exaltação sexual da escrava e o culto à sensualidade da mulata, tão caros à nossa cultura branca e machista, vistos sob um novo prisma, mais do que explicar os ataques sexuais às escravas, parecem cumprir uma função justificadora (Giacomini, 1988, p. 66).
\end{abstract}

Essa crença de que a responsabilidade pelo próprio estupro era da escravizada norteava muitas das relações de mulheres negras com as brancas. Historiadoras relatam incontáveis casos de tortura, amputações e todo o tipo de violência sobre as mulheres escravizadas por ordem do rancor da branca ofendida (Giacomini, 1988, p. 68).

Enquanto durou o tráfico, a estimativa média dos anos de vida dos escravos era pequena: "7 anos para Simonsen, 12 para Goulart, 5 para Freitas - mas há total unanimidade na literatura não apologética em apontar uma taxa natural de crescimento da população escrava negativa" (Vainer, 1979, apud Giacomini, 1988, p. 23). Em discurso na Câmara Superior Brasileira, em 1883, o então Senador Cristiano Otoni perguntava: “o 
escravo trabalhando um ano, além de plantar e colher para seu sustento, dava um produto líquido que cobria pelo menos o seu valor, do $2^{\circ}$ ano em diante era tudo lucro. Portanto, para que se preocuparem muito com eles, quando era tão fácil obter novos por preços baixos?" (Giacomini, 1988, p. 24). Mas em 1850, com a extinção do tráfico africano, houve uma profunda inflexão na experiência de cativeiro.

Negras e negros, chamados de crioulos, que tinham certa estabilidade na região onde nasceram, ficaram vulneráveis ao tráfico interno. As grandes fazendas de café do Sudeste, que até então recebiam levas e levas de africanos, seguiram em expansão após a extinção do tráfico negreiro. Uma rede de intermediários substituiu a empresa negreira em um mercado cativo de dimensões nacionais. O processo gerou alterações na vida cotidiana, especialmente de homens e mulheres negros. A prática de respeitar grupos familiares em partilhas e vendas de cativos que beneficiava crioulos se restringiu depois de 1850 (MATTOS, 2013, p. 115-119). A história de duas mulheres, relatada pela historiadora Hebe Mattos a partir de análise de registros criminais, mostra o desespero frente à violência do desenraizamento gerado pelo tráfico interno:

Justina e Maria Rosa cometeram aquele tipo de crime para o qual não se encontra justificativa além da loucura e do desespero. Mataram cada uma seus três filhos menores e depois tentaram, sem sucesso, o suicídio. Escravas, espera-se encontrar por trás de tal gesto uma cruel história de violência, tortura e humilhação. Não é, entretanto, o que transparece nos depoimentos, inclusive o delas próprias e de seus companheiros de cativeiro (...). À pergunta de por que Justina matara os filhos, as respostas invariavelmente consideravam uma única razão: porque ela estava convencida de que seria vendida pelo senhor, na viagem que, no dia seguinte, fariam para o Sertão do Morro do Coco (MATTOS, 2013, p. 120-122).

Mattos (2013) reúne uma série de outros casos de suicídio, assassinato de senhores, de administradores de fazendas e de fugas provocadas pela possibilidade de desenraizamento devido ao tráfico interno. Não que alguma condição de escravidão fosse boa, mas mulheres e homens escravizados no Brasil desde o nascimento sabiam como ela podia ser muito pior distante de suas comunidades.

No espaço urbano, durante todo o período colonial, a mulher negra ocupou um espaço central, especialmente no pequeno comércio, exercido por forras ou as chamadas escravas de ganho, que, geralmente tinham um valor diário a entregar aos senhores. O que excedesse esse valor diário costumava ser acumulado por essas mulheres, muitas vezes para a compra da liberdade. $\mathrm{O}$ valor que conseguia ganhar e quanto precisava entregar ao senhor 
variava de acordo com a cidade, a ocupação, a condição de saúde, a arbitrariedade do proprietário, dentre outros fatores (SOARES, 1996, p. 57). A Lei do Ventre Livre, de 1871, regulamentou o direito de escravos acumularem pecúlio.

As escravizadas de ganho podiam viver com o senhor ou o não. Era comum que senhores tivessem de dois a três escravizados de ganho e assim vivessem da renda gerada por esses. Em cerca de três anos, segundo Cecília Moreira Soares, era possível receber de volta o que foi pago, o que tornava a modalidade lucrativa para os proprietários, ao mesmo tempo que era a principal possibilidade de compra da própria alforria às mulheres escravizadas (SOARES, 1996, p. 58).

Segundo dados registrados por Sheila de Castro Faria (2000, p. 70), as mulheres eram dois terços do total de pessoas alforriadas no Rio de Janeiro entre 1807 e 1831. Além de conseguirem acumular pecúlio, há outros fatores para tanto: custavam menos que os homens e conseguiam mais rapidamente acumular o valor necessário para a alforria; muitas vezes eram vítimas de abusos sexuais e paradoxalmente alvos de afetos dos senhores, o que podia facilitar o processo da alforria (SOARES, 1996, p. 71).

Em São Paulo, 3.506 dentre os 4.810 trabalhadores domésticos eram livres em 1872, condição de $88 \%$ da população da cidade no período. Com a crise de mão de obra escrava iniciada em 1850 e intensificada em 1871 pela Lei do Ventre Livre - que libertava filhas e filhos de escravizadas depois que completassem 21 anos de idade, delineava-se na cidade a substituição por trabalhadores livres nos setores de produção e serviços (TELLES, 2015, p. 168; CARRIL, 2006, p. 74). O legislativo municipal regulamentou então deveres e obrigações de trabalhadores livres pelo uso de três instrumentos: "Livro de Inscrição de Empregados", "Livro de certificados" e cadernetas de trabalho. A pesquisadora Lorena Féres da Silva Telles analisou os dois primeiros para compreender como era o trabalho doméstico livre às vésperas da abolição.

Trabalhadoras deveriam ir à subdelegacia de polícia para declarar: nome, sexo, idade, nacionalidade, filiação, cor, estado, classe de ocupação "e mais características que possam de futuro servir de base à prova de sua identidade". Os vereadores estabeleceram como procedimentos para empregadores: contratar trabalhadores matriculados e escrever o contrato na caderneta que deveria ser levada à secretaria de polícia dentro de 24 horas para ser transcrito no livro de certificados; informar motivo de saída e comportamento enquanto servia; multa se não cumprissem os procedimentos. Empregados não poderiam abandonar o trabalho sem 8 dias de aviso ou "causa justa", tendo que pagar multa ou passar 8 dias na prisão se assim não fizessem. 
Neste período se expandiu a chegada de imigrantes europeus em São Paulo, com o incentivo da Lei Provincial de 1871 - que subsidiava as despesas de viagens dos imigrantes brancos pelo governo e a construção da Hospedaria do Imigrante. Entre julho de 1886 e julho de 1887, foram anotados no livro de certificados 1.273 contratos de trabalho referentes a 1.011 criados. Em julho de 1886, nas 1.001 primeiras inscrições, eram 626 trabalhadoras domésticas mulheres, deste as quais 397 negras, e 375 homens (TELLES, 2015, p. 172).

O registro de Maria Fausta Otoni, de 23 anos, nascida na cidade do Rio de Janeiro, cor fula, filiação desconhecida, solteira, para prestar serviços domésticos a Ana Luiza Abranches evidencia como este trabalho dito livre mantinha relações de dependência e de trabalho não remunerado correlatas à escravidão:

(...) está em minha casa desde criança como órfã e que quando completou a idade de 21 anos não quis retirar-se e nem ficar em minha casa como alugada, mas sim como minha companheira (...) além de outras gratificações, 6 mil por mês para seus alfinetes (TELLES, 2015, p. 186).

O registro de Maria Teresa, sem maiores detalhes de quem era ela, registrava que fora contratada por Fredonie Ada Moore para serviços domésticos "sem vencimentos senão comida e roupa" (TELLES, 2015, p. 186). Vale lembrar que as empregadas domésticas só conquistaram os mesmos direitos de outros trabalhadores, ao menos no papel, em 2013, 125 anos depois da abolição, graças à luta de mulheres negras organizadas.

Apesar de o trabalho doméstico ter sido uma importante ocupação de mulheres negras forras, havia as negras livres que desempenhavam o mesmo papel social que as escravizadas de ganho, mas tudo o que geravam lhes pertencia.

Esse tipo de atividade não era estranho às negras importadas pelo tráfico negreiro, pois em muitas sociedades africanas delegava-se às mulheres a tarefa de subsistência doméstica e circulação de gêneros de primeira necessidade. Muitas ganhadeiras africanas eram provenientes da costa ocidental da África, onde o pequeno comércio era tarefa essencialmente feminina, garantindo às mulheres papéis econômicos importantes. Esta explicação não excluiu mulheres de grupos bantos, que praticavam igualmente o comércio ambulante em suas terras (SOARES, 1996, p. 60).

Segundo o censo de 1849, da Freguesia de Santana, em Salvador, as mulheres negras eram especialmente negociantes, conforme é possível visualizar na Tabela 2. Elas 
comercializavam produtos como hortaliças, verduras, peixes, frutas, comida pronta, fazenda e louças.

Quadro 3: Ocupações de libertas na freguesia de Santana - 1849

\begin{tabular}{|c|c|c|c|c|c|c|c|c|}
\hline \multirow[b]{2}{*}{ Ocupação } & \multirow[b]{2}{*}{ Africana } & \multicolumn{3}{|c|}{ Origem } & \multirow[b]{2}{*}{ Angola } & \multirow[b]{2}{*}{ Mina } & \multirow[b]{2}{*}{ Bornu } & \multirow[b]{2}{*}{ Total } \\
\hline & & Nagô & Jeje & Tapa & & & & \\
\hline Doméstica & 2 & - & - & - & - & - & - & 2 \\
\hline Quitandeira & 10 & 8 & 11 & 2 & 3 & 1 & - & 35 \\
\hline Mercandeja & 34 & 45 & 14 & - & 1 & 2 & 1 & 97 \\
\hline Costureira & 1 & - & - & - & - & - & - & 1 \\
\hline Lavadeira & 3 & 2 & 3 & - & - & - & - & 8 \\
\hline Cozinheira & - & - & 1 & - & - & - & - & 1 \\
\hline Alugada & 1 & - & 2 & - & - & - & - & 3 \\
\hline $\mathrm{N}$ egócios & 7 & 2 & 1 & - & - & - & - & 10 \\
\hline Mendiga & 4 & - & 5 & - & - & 1 & - & 10 \\
\hline Proprietár. & - & - & 1 & - & - & - & - & 1 \\
\hline "Ganho" & 11 & 4 & - & - & 1 & - & - & 16 \\
\hline Pedreira & 1 & 1 & - & - & - & - & - & 2 \\
\hline Vive de escr & - & 1 & $\cdot$ & - & - & - & - & 1 \\
\hline Sust.filhos & 1 & - & 1 & - & - & - & - & 2 \\
\hline Roceira & 2 & - & 1 & - & - & - & - & 3 \\
\hline S/Especific. & 4 & 2 & - & - & - & - & - & 7 \\
\hline Total & 81 & 65 & 40 & 2 & 5 & 4 & - & 198 \\
\hline
\end{tabular}

FONTE: Censo Freguesia de Santana - 1849, APEBA, Série Escravos, maço 2898

Fonte: SOARES, 1996, p. 59

Em Salvador, no final do século XVIII, mulheres negras chegaram a monopolizar o comércio de peixes, carnes, verduras e frutas. Participavam de esquemas de especulação de mercados e atravessamentos, definindo valores e a circulação das mercadorias. Há relatos de que pescadores só repassavam peixes a elas. Também distribuíam produtos de contrabando, revendendo produtos furtados. Ocupavam praças e ruas de pontos estratégicos das cidades. Preocupavam autoridades, especialmente depois da Revolta dos Malês, quando muitas foram acusadas de participar da revolta e de alimentar revoltosos (SOARES, 1996, p. 61-62).

Mulheres negras, portanto, ocupavam espaços públicos durante o Brasil Colônia e o Brasil Império fossem forras ou escravizadas. A história de Teodora Dias da Cunha, escravizada doméstica na cidade de São Paulo no final da década de 1860, é exemplar de como essas mulheres, mesmo que não fossem de ganho, estavam nas ruas, e as estratégias que elaboravam em busca da liberdade. Maria Cristina Cortez Wissenbach, ao pesquisar autos criminais que envolvem escravizados e forros na cidade de São Paulo na segunda metade do século XIX, encontrou um conjunto de cartas escritas a mando da africana Teodora. 
O processo criminal de 1867-1872 relatava que a africana era originária de algum território subordinado ao reino do Congo e foi levada para a cidade de Limeira, no interior de São Paulo, onde constituiu família. Por volta de 1862 foi negociada em Campinas, separada do marido e do filho, e vendida por um mercador para ser escrava doméstica no bairro da Liberdade, em São Paulo. Ao circular pelas ruas, para atender a pedidos de seu proprietário, conheceu Claro Antonio dos Santos, crioulo da região do Paraná, escravo de ganho, que sabia ler e escrever. Teodora pagava para que Claro escrevesse cartas destinadas ao marido, ao filho e ao senhor do marido. As cartas nunca chegaram. Sete delas foram anexadas aos autos da comarca de São Paulo como prova da participação de Teodora em um roubo praticado por Claro e um parceiro.

\footnotetext{
Meu marido Luís, São Paulo

Muito hei de stimar que Vance esteja com saúde/ eu estou aqui na cidade/ eu vos escrevo para

Vance se lembrar daquela promeça que nos fizemos/ eu hei de procurar por voce/ mando muita lembrança para voce/ e ajunta um dinheiro la/ se puder vir falar comigo venha/ senão puder me manda a resposta e dinheiro vá juntando la mesmo/ se cazo me arranjar por aqui manda propria la. Dessa vossa mulher, Theodora, escrava do connio terra que foi vendida na vacaria" (WISSENBACH, 2012, p. 231).
}

Teodora, apesar de analfabeta, constituiu para si um lugar no mundo da escrita ao ditar desejos e intenções de forma organizada. "Teodora dominava parcelas significativas dos códigos do universo citadino e culto, compreendendo a relevância da escrita e valendose dela como uma estratégia" (WISSENBACH, 2012, p. 234).

A resistência à escravidão, que se dava de inúmeras formas - escrita, compra de alforria, fuga, assassinato, suicídio, para ficar apenas nos casos aqui relatados - tem nos quilombos sua grande simbologia e expressividade. Pela história dos quilombos, podemos compreender os diferentes ciclos da escravidão no Brasil.

Beatriz Nascimento, intelectual, historiadora e militante negra, assassinada ao defender uma amiga da violência de seu companheiro, em 1995, foi uma das principais estudiosas dessa resistência. No artigo $O$ conceito de quilombo e a resistência afrobrasileira, escrito na década de 1980, Beatriz caracterizou os quilombos como instituições africanas de origem banto, angolana. Segundo a autora, o período em que portugueses intensificaram o tráfico de pessoas de África para o Brasil, no século XVII, se aliaram ao rei do Congo para penetrar o interior africano. Havia muitos conflitos entre etnias neste período, fosse por aderir ao tráfico português ou por resistência à invasão. 
Bantos, especificamente do grupo imbangala, também conhecidos como jaga, resistiram por um longo período ao rei do Congo e aos portugueses. Povo nômade, com muitos caçadores treinados e em guerra contínua, criavam kilombos, palavra de muitos sentidos: indivíduos de outros grupos, que se incorporavam à sociedade imbangala; o território ou campo de guerra; a casa sagrada onde aconteciam rituais de iniciação; e também o acampamento de escravos fugitivos. "Observando a inter-relação Brasil-Angola diante do tráfico negreiro, não é difícil estabelecer conexão entre a história dessa prática na África (Angola) e aqui. A dificuldade está em estabelecer linhas de contato direto, como entre a formação de um quilombo aqui e suas origens territoriais e de composição étnica em Angola" (NASCIMENTO, B., 2008, p. 77).

Palmares se estrutura em 1584, auge da resistência jaga. No século seguinte a etnia se aliaria ao esforço negreiro português. Beatriz Nascimento apresenta outras evidências desta conexão: o chefe africano de Palmares, Ganga Zumba, foi descrito com o cabelo em tranças longas, adornadas por conchas, idêntico ao adorno utilizado pelo rei imbangala, que recebia o título Gaga. Na documentação oficial portuguesa a primeira referência ao termo quilombo é de 1559, mas somente em 1740, depois da guerra à República de Palmares, o termo foi definido: "toda a habitação de negros fugidos que passem de cinco, em parte desprovida, ainda que não tenham ranchos levantados nem se achem pilões neles" (NASCIMENTO, B., 2008, p. 81).

Segundo Beatriz Nascimento, no período colonial, os quilombos se caracterizavam pela formação de grandes Estados, sistemas sociais alternativos, como foi Palmares ou, em Minas Gerais, o quilombo da comarca do Rio das Mortes, desmembrado em 1750. Os grandes quilombos acompanhavam os ciclos econômicos do Brasil colonial: o açúcar no Nordeste, depois o ciclo de ouro em Minas. Estes quilombos do século XVIII, segundo Nascimento, eram diferente dos posteriores porque, por mais que recebessem africanos de diversas etnias, inclusive indígenas ou brancos perseguidos pelo sistema colonial, estavam estruturados em um espaço territorial e voltados para um tipo de economia muito vinculados a grupos étnicos africanos.

Já no século XIX, há uma proliferação de quilombos que se distanciam do modelo africano; a fuga de pessoas de diferentes grupos étnicos e de pequenos grupos passa a ser uma instituição decorrente da instabilidade do sistema escravagista. "A oscilação das atividades econômicas, ora numa região, ora noutra, provocava muitas vezes o afrouxamento dos laços entre africanos escravizados e seus senhores. A fuga passa a ser 
uma instituição decorrente dessa fragilidade colonial e integrante da ordem do quilombo" (NASCIMENTO, B., 2008, p. 81).

Em 1850, foi promulgada também a Lei de Terras, que estabeleceu a apropriação fundiária por meio da compra, não mais por posse, impedindo o acesso de negras e negros forros à pequena propriedade (CARRIL, 2006, p. 58). Neste período, os grandes quilombos são formados em morros e nas periferias dos centros urbanos. E é no final do século XIX que quilombo se torna símbolo de resistência. Resistência à escravidão, e também ao racismo e à desigualdade que perdura depois da abolição (NASCIMENTO, B., 2008, p. $81)$.

\section{O movimento de mulheres negras}

Lá em Alagoas / Acotirene surgiu Mulher negra / À escravidão resistiu Verdadeira / Luz do saber e da paz Mulher guerreira / A esperança nos traz!

Oyá Epahei!! / Iyá de Palmares chegou Kaô-kabyensilê / Protege nosso povo, meu rei Foi na Serra da Barriga / Que o quilombo enraizou Mãe, avó e conselheira / Acotirene lutou! Escreve a história Ilu Obá Demarca a minha terral o meu lugar! (Iya de Plamares, de Analu Muniz, repertório do

Carnaval 2018 do Ilú Obá de Min)

Surgiu um movimento Uma Onda Negra Sociedades de Mulheres Eleko e Geledés Enegrecendo o feminismo

Combatendo o racismo E toda forma de opressão Vozes negras em favor da igualdade

Máxima da Constituição

Nós somos o Movimento

O mundo se move em nós A ginga das nossas ancestrais Ecoam em nossa voz

(O Mundo Se Move Em Nós, da Coletiva Negas Pretas - Célia Santos, Lisandra, Jéssica, Juliane, Daniela, Nanci, Ana Paula, Mayara e Cibelle, repertório do 
É hora das ruas se abrirem É o Ilu Obá!

Nesse carnaval, negras vozes unidas

Mãos dadas pra revolucionar Mãe Stella, Senhora, Yanassō Lecis, Conceições, Suelis e Zezés

Ialodês peço a Bênção e Axé No rastro dessas mulheres Saberes e determinação

Traçamos nosso caminhar Histórias que jamais se apagarão

Sua força, nós herdamos

Cantamos sua canção Ideais , multiplicamos

São sementes que florescem nosso chão

Não estamos sós

Em cada uma trazemos todas nós

Somos todas irmãs

Alafia, é tempo de Alakan

(Não estamos sós, de Nenê Cintra e Dri Quedas, repertório do Carnaval 2019 do Ilú Obá de Min)

A organização política de mulheres negras data desde, pelo menos, o século XVIII. O poder feminino, de organizar mulheres politicamente, está no cerne da ialodê muito antes da existência de qualquer movimento de mulheres ou do feminismo. Além de título a Oxum e Nanã, ialodê é o título dado a mulheres que atuam politicamente em defesa das mulheres, detentoras de poder e capacidade de luta. "Ialodê, para além das esferas rituais, é também um cargo político conferido à representante das mulheres nas instâncias públicas de poder e governo. O título refere-se a mulheres emblemáticas, lideranças políticas femininas que realizam suas atividades nos grupamentos urbanos, nas cidades" (WERNECK, 2007). Nos quilombos, a liderança feminina era reconhecida em figuras como Acotirene, matriarca de Palmares no final do século XVI ou início do século XVII, e Tereza de Benguela, liderança do Quilombo de Quariterê, no século XVIII, conhecida na região do atual Mato Grosso como Rainha Tereza.

No século XIX, ainda durante o período escravocrata, as irmandades da Boa Morte e de Nossa Senhora do Rosário dos Pretos - que reuniam praticantes do candomblé e do catolicismo popular - organizavam compras coletivas de alforrias, garantiram enterros dignos, mantinham festas aos espíritos de seus antepassados e, tanto nos segredos do candomblé quanto nos ritos católicos, cultuavam orixás e nkisis (MARQUES, 2009). Das anciãs organizadas na Irmandade da Boa Morte, nos fundos da Igreja da Barroquinha, em Salvador, nasceu o primeiro candomblé do Brasil, possivelmente antes de 1820, 
oficialmente entre 1830 e 1840. Depois da Revolta dos Malês, acredita-se que, para se afastar da perseguição policial, a Irmandade da Boa Morte se mudou para a cidade de Cachoeira, também na Bahia.

Em todo o país, periódicos da imprensa negra eram importantes veículos de organização política e floresceram entre a última década do século XIX até mais ou menos 1950, nesses jornais, mulheres negras publicavam artigos, crônicas e ocupavam postos importantes como editoras ou redatoras. Exemplos são Eunice Cunha, redatora no Paulistano Clarim D’Alvorada, possivelmente entre 1924 e 1932, e Maria de Lurdes Valle Nascimento, diretora e gerente do jornal Quilombo, entre 1948 e 1950, quando também publicava a coluna Fala Mulher.

Em 1936, Laudelina de Campos Mello foi uma das mulheres negras que criou a primeira associação de empregadas domésticas do Brasil, na cidade de Campinas, em São Paulo. A organização, financiada pelas próprias empregadas domésticas, foi muito importante para negociar condições mínimas às mulheres que, com o trabalho doméstico, garantiam minimamente a sobrevivência de suas comunidades no pós-abolição, essencial para pavimentar o caminho para a conquista de direitos trabalhistas quase 80 anos depois. Laudelina também foi militante da Frente Negra Brasileira, organização presente em diversos estados brasileiros, que chegou a ter mais de oito mil membros. Transformada em partido político em 1936, um ano depois foi fechada pelo Estado Novo.

Do Teatro Experimental do Negro - TEN, idealizado por Abdias do Nascimento e fundado em 1944, participaram inúmeras mulheres negras, como a atriz Ruth de Souza e a própria Maria de Lurdes Valle Nascimento. Além de diretora do jornal Quilombo, Maria de Lurdes foi assistente social e uma das criadoras do Conselho Nacional de Mulheres Negras, em 1950.

Durante a ditadura militar, mulheres negras participaram ativamente de organizações de resistência ao regime. Em 1978, na fundação do Movimento Negro Unificado, a presença de Lélia Gonzalez e outras mulheres negras nas escadarias do Teatro Municipal de São Paulo foi visibilizada quando a jornalista Neusa Maria Pereira pegou o microfone para denunciar as situações de racismo e sexismo vivenciadas por mulheres negras.

Na redemocratização, em 1983, foi criado em São Paulo o Conselho Estadual da Condição Feminina, em sua composição inicial, de um total de 17 mulheres, nenhuma era negra. Provocadas pela radialista Marta Arruda, mulheres negras que militavam ou no movimento negro ou no movimento feminista se juntaram no Coletivo de Mulheres Negras, 
conquistaram um assento no conselho, ocupado por Thereza Santos, que também havia participado do TEN, no Rio de Janeiro, e depois foi uma das fundadoras do Cecan, em São Paulo. Dentre as 15 mulheres que compuseram o conselho estavam Marta Arruda, Thereza Santos, e Sueli Carneiro.

Anos depois, em 1987, no Conselho Nacional dos Direitos da Mulher, foi criada uma coordenadoria dos direitos da mulher negra, comandada por Sueli Carneiro. A estrutura governamental foi importante para apoiar feministas e mulheres do movimento negro para participarem da Constituinte e organizarem atividades de denúncias no centenário da abolição.

Do Encontro Nacional Mulher e Constituinte, em agosto de 1986, participaram Benedita da Silva e Lélia Gonzalez, que compunham o Conselho Nacional dos Direitos da Mulher, e foram responsáveis por inscrever as demandas das mulheres negras nas comissões temáticas que encaminharam propostas à Assembleia Constituinte. A única parlamentar negra eleita para a Constituinte foi Benedita da Silva (PT-RJ). Ao lado de Carlos Alberto Caó (PDT-RJ), Edmilson Valentim (PT-RJ) e Paulo Paim (PT-RS) formou a Bancada Negra da Constituinte.

A Carta das Mulheres Brasileiras aos Constituintes, ganhou força política na presença constante de mulheres organizadas no Congresso Nacional, no chamado Lobby do Batom, que fazia o corpo a corpo com parlamentares e teve $80 \%$ de suas reivindicações incluídas na nova Constituição ou nas mudanças nos códigos civil, penal e outras leis complementares. "Pela primeira vez na história do Brasil, mulheres e homens foram considerados iguais, em direitos e obrigações. Crianças adotadas ou nascidas fora de uma relação de casamento seriam consideradas filhas legítimas, com direito de herança e uso do nome do pai. Licença-maternidade de 120 dias, direito à posse de terra, igualdade de salários, mecanismos para coibir a violência doméstica” (SANTANA, B., 2020).

Em 1984, o movimento negro já havia promovido um primeiro encontro, O Negro e a Constituinte, quando foram listadas as demandas de ensino de história da África nas escolas, efetivada 15 anos depois, com a aprovação da Lei 10.639/2003, que torna obrigatório o ensino de história e cultura afro-brasileira nos ensinos fundamental e médio; estatização do sistema de saúde e dos transportes coletivos, licença maternidade de seis meses, assistência a idosos, descriminalização do aborto, atividades produtivas e remuneradas a presos e unificação das polícias civil, dentre outras. As duas reivindicações incorporadas na nova constituição foram tornar o racismo crime inafiançável e imprescritível, e o direito de propriedade às comunidades remanescentes de quilombos. 
Dos Direitos e Garantias Fundamentais

Dos direitos e deveres individuais e coletivos

Art. $5^{\circ}$ Todos são iguais perante a lei, sem distinção de qualquer natureza, garantindo-se aos brasileiros e aos estrangeiros residentes no País a inviolabilidade do direito à vida, à liberdade, à igualdade, à segurança e à propriedade, nos termos seguintes:

XLII - a prática do racismo constitui crime inafiançável e imprescritível, sujeito à pena de reclusão, nos termos da lei.

O inciso constitucional foi tipificado um ano depois, na lei complementar 7.716/89, conhecida como Lei Caó, que definiu a punição de crimes em razão de preconceito e discriminação de raça ou cor, passando a considerar as condutas discriminatórias como crimes.

Ato das Disposições Constitucionais Transitórias

Art. 68 Aos remanescentes das comunidades dos quilombos que estejam ocupando suas terras é reconhecida a propriedade definitiva, devendo o Estado emitir-lhes os títulos respectivos.

Além da grande movimentação em torno da Constituinte, o governo Sarney pretendia celebrar, em 1988, os cem anos da abolição. O movimento negro aproveitou como oportunidade para denunciar o racismo e a falácia de que a assinatura da Lei Áurea teria libertado negras e negros. No Conselho Nacional dos Direitos da Mulher, mulheres negras realizaram o Tribunal Winnie Mandela, com o objetivo de avaliar as repercussões econômicas, sociais, políticas e ideológicas da população negra, em especial da mulher negra. Entre maio e novembro de 1988 foram promovidas sessões nas principais faculdades de Direito do país para julgar os efeitos da Lei Áurea, assinada cem anos antes, sob o título “100 anos de abolição, 100 anos de discriminação: a mulher negra na sociedade brasileira”.

Depois de apresentar dados, relatos e reflexões sobre as condições da mulher negra no mercado de trabalho, imagens e estereótipos nos meios de comunicação, produção literária, o encerramento do Tribunal em 20 de novembro, dia de Zumbi dos Palmares, foi teatral e relatado por Sueli Carneiro como impactante. Joel Rufino, historiador e escritor negro, produziu o roteiro de uma peça, em que uma personagem de 117 anos, encenada por Ruth de Souza, contou a história de sua vida.

E é também a partir de 1988 que se pode falar de um movimento social próprio, independente dos movimentos negro, feminista, sindicatos e partidos políticos: o movimento de mulheres negras. Um ano antes, durante o IX Encontro Nacional Feminista, 
em Garanhuns, Pernambuco, as cerca de 200 mulheres negras presentes se indignaram com a falta de espaço para a questão racial. Decidiram, então, organizar o I Encontro Nacional da Mulher Negra, que aconteceu na cidade de Valença, Rio de Janeiro, em dezembro de 1988.

Imagem 12: Informativo sobre o I Encontro Nacional de Mulheres Negras

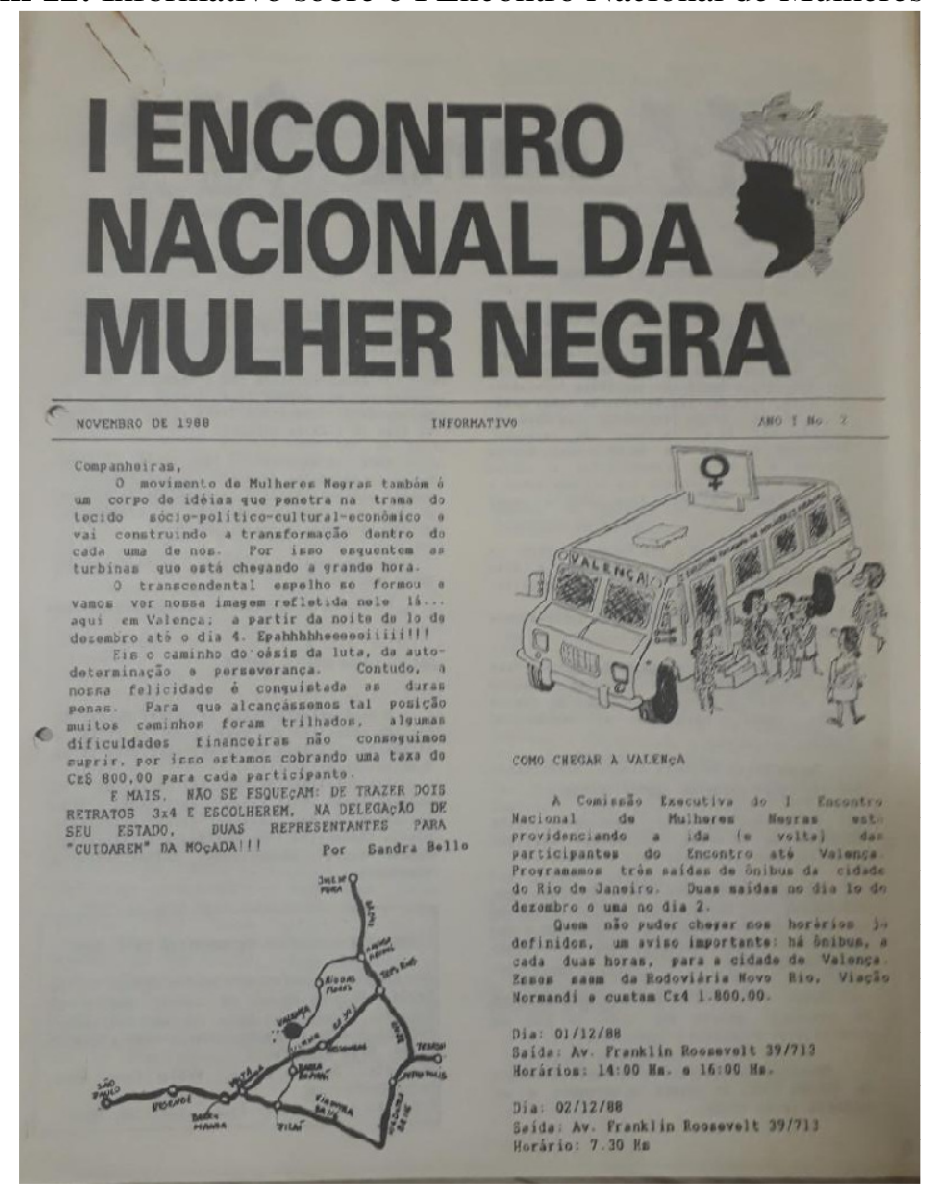

Fonte: Acervo Geledés

O informativo, distribuído em setembro de 1988, registrava:

Esse encontro tem por finalidade precípua, congregar mulheres de todo território nacional e levar-nos a refletir sobre a verdadeira razão que nos torna diferentes, ou a razão pela qual nos é dado um tratamento diferenciados dos demais indivíduos que compõe a sociedade (...).

Gostaríamos de deixar claro que não é nossa intenção provocar um 'racha' nos movimentos sociais como alguns elementos nos acusam. Nosso objetivo é que nós, mulheres negras, comecemos a criar nossos próprios referenciais, deixando de olhar o mundo pela ótica do homem, tanto o negro quanto o branco, ou da mulher branca. O sentido da expressão "criar nossos próprios referenciais' é que queremos estar lado a lado com as(os) companheiras(os) na luta pela transformação social, queremos nos tornar porta-vozes de nossas próprias ideias e necessidades, enfim queremos uma posição de igualdade nessa luta (...). Cabe lembrar ainda que o 
movimento social, como um todo, considera que a questão racial é secundária e que será resolvida na medida em que acabarem as desigualdades sociais.

Participaram 450 mulheres negras, de 17 estados, que vinham de diferentes setores e experiências organizativas: governo, movimento feminista, movimento negro, sindicatos, associações comunitárias ou religiosas. O tema central do encontro era a organização do movimento nascente de mulheres negras. Os objetivos haviam sido divulgados no mês de setembro:

\begin{abstract}
Denunciar as desigualdades sexuais, sociais e raciais existentes; fazer emergir formas locais de luta e auto-determinação, elaborar documento para uma política alternativa de desenvolvimento; encaminhar uma perspectiva unitária de luta dentro da diversidade social, cultural e política; estabelecer grupos de trabalho para registro e posterior retorno as participantes; realizar um diagnóstico da mulheres negras; discutir as formas de organização das mulheres negras; elaborar propostas políticas que façam avançar a organização de mulheres negras colocando para o mundo a existência do movimento de mulheres negras do Brasil de forma unitária e diferentes vertentes políticas.
\end{abstract}

Informações sobre a estruturação do movimento de mulheres negras, a partir de 1988, foram por mim escritas, a partir de pesquisa documental e entrevistas com Sueli Carneiro, Solimar e Suelaine Carneiro, Sonia Nascimento e Nilza Iraci, todas de Geledés Instituto da Mulher Negra; a escritora Cidinha da Silva; Regina Adami, do Irohin Centro de Documentação, Comunicação e Memória Afro-brasileira; contribuições de Marcia Lima, professora do departamento de sociologia da FFLCH-USP e coordenadora do AFROCebrap, para biografia Ato das Disposições Constitucionais Transitórias

Art. 68 Aos remanescentes das comunidades dos quilombos que estejam ocupando suas terras é reconhecida a propriedade definitiva, devendo o Estado emitir-lhes os títulos respectivos. que escrevi sobre Sueli Carneiro, a ser publicada ainda em 2020. Para evitar a reescrita, os parágrafos que seguem, até a Conferência de Durban, foram produzidos para o livro, mas, como ainda serão editados e revisados, é provável que sejam bastante modificados. De todo modo, fica registrado o alerta.

O encontro de Valença, composto por palestras, oficinas e grupos de trabalho, foi seguido pela organização de fóruns estaduais em quase todo o país. Entre 1988 e 1991, grupos de mulheres negras se organizaram nas estruturas internas do movimento negro, do movimento feminista, dos partidos, das centrais sindicais. Foram fundadas também 
inúmeras organizações não-governamentais como Geledés Instituto da Mulher Negra, que passa a operar no final de 1988, Casa de Cultura da Mulher Negra de Santos, em 1990, Criola, no Rio de Janeiro, em 1992, e tantas outras, que se multiplicaram nos diferentes estados ao longo da década de 1990.

Lélia Gonzalez pública, no mesmo dezembro de 1988, em um periódico do MNU, um artigo crítico ao Encontro (GONZALEZ, 2008, p. 363). Apesar de reconhecer o quão fundamental era a organização política de mulheres negras, afirmou que o evento estava fechado em si mesmo, em um sexismo sectário que o distanciava da maior parte das mulheres negras do país. Como exemplo, trouxe a declaração de uma das mulheres que compunham a executiva do encontro de que a revolução só seria possível com a radicalização da luta entre homens e mulheres. Para Lélia, a dialética não cabia nesse tipo de formulação - branca - de macho opressor versus fêmea oprimida. A opressão racial e a exploração de classe ficariam, então, esquecidas.

Estava identificado por Lélia o que chamou de um feminismo sexista no interior do movimento de mulheres negras, que repetia o chavão machista de que política é coisa de homem, a identificação com um feminismo branco e ocidental, o desconhecimento da história de luta de mulheres negras, a falta de identidade própria. Lélia explicita no texto que, em sua visão, debates políticos amplos foram descaracterizados como políticopartidários e que mulheres do PT e do PDT foram acusadas de desarticular o bom andamento do encontro. A recomendação era de "aprender (e refletir) com mulheres negras que, do abismo de seu anonimato, têm dado provas eloquentes de sabedoria”, por estarem pautadas pela solidariedade e coletivismo.

Para Lélia Gonzalez, as mulheres negras deviam assumir-se como sujeitos políticos que denuncia, a exploração econômica e da subordinação racial e sexual, para lutar com todas e todos pela libertação de todas e todos.

Em 1991, aconteceu o II Encontro Nacional de Mulheres Negras (ENMN), em Salvador (BA), com a participação de 430 mulheres de 17 estados. Nele, foram planejados encontros estaduais e temáticos, como o Seminário Nacional Políticas e Direitos Reprodutivos das Mulheres Negras, em Itapecerica da Serra, em 1993. Cada organização participava das diferentes instâncias de decisão e por isso pautava a atuação regional e nacional, assim como era pautada pelos debates coletivos. Desde então, preservando a autonomia e a independência de cada entidade, o movimento de mulheres negras tem sido feliz em compartilhar coletivamente as definições estratégicas. 
Assim como se articulavam nacionalmente, entidades negras e de mulheres negras se organizavam por toda a parte. Em 1992, entre 19 e 25 de julho, foi realizado o I Encontro de Mulheres Negras Latino-Americanas e Caribenhas, com representantes de 70 países. Sueli Carneiro, de Geledés, Jurema Werneck e Lucia Xavier, de Criola, representaram as organizações de mulheres negras brasileiras.

Durante o encontro, foi fundada a Rede de Mulheres Negras AfroLatinoamericana e Afrocaribenhas (RMAA), que assumiu papel central nas denúncias e articulações internacionais contra o racismo e o sexismo nas conferências da ONU na década de 1990, especialmente nas conquistas da Conferência de Durban, em 2001. Uma das principais figuras da rede, Epsy Campbell Barr, é hoje vice-presidenta da Costa Rica. Por Geledés, Nilza Iraci segue participando da entidade.

Naquele primeiro encontro, o 25 de julho ficou definido como marco internacional da luta e da resistência da mulher negra. No Brasil, em 2014, Dilma Rousseff decretou, pela lei 12.987/2014, o 25 de julho como o Dia Nacional de Tereza de Benguela e da Mulher Negra. Tereza de Benguela foi, durante o século XVIII, uma líder quilombola que resistiu à escravidão por pelo menos duas décadas. A data tem contribuído para dar visibilidade às organizações e pautas de mulheres negras.

Em 1991, de 14 a 17 de novembro, no Ginásio do Pacaembu, aconteceu o I Encontro Nacional de Entidades Negras, com objetivo de avaliar e discutir as concepções, desafios e perspectivas do movimento negro.

Foram destacados como desafios principais naquele momento: a esterilização em massa das mulheres, o extermínio programado de crianças e adolescentes, a discriminação no mercado de trabalho, a discriminação da mulher negra, o aumento geométrico da miséria, a prostituição infantil, a fome, a educação, a cultura, a religião, o esporte.

Fortalecer as entidades negras, ampliar a articulação com outros movimentos e fazer campanhas contra a pena de morte foram encaminhamentos tirados do encontro, assim como a formulação de plataformas de campanhas negras para as eleições de 1992, o apoio a Cuba, Haiti e à luta contra o apartheid na África do Sul. A oposição ao projeto neoliberal de destruição das estatais e privatização da saúde, da educação, da previdência também constava no documento final.

\section{(...)}

Depois da queda do muro de Berlim, em 1989, a Organização das Nações Unidas (ONU) promoveu uma série de conferências mundiais para repactuar quais seriam as diretrizes de seus países membros. Tais espaços se consolidaram como fóruns de 
recomendações de políticas públicas, relativamente respeitados pelos governos brasileiros até 2017.

A consciência de que os processos de globalização neoliberais agudizam a pobreza e a desigualdade crescia entre as mulheres. As estratégias de ação deveriam ter uma perspectiva internacionalista, com a parceria de diversos outros movimentos e instituições. Além de desenvolver ações regionais na América Latina e no Caribe, estavam articuladas para participar de fóruns internacionais também com as mulheres do Norte do mundo, naquele momento chamado de Primeiro Mundo.

As mulheres negras, em composição com o movimento feminista internacional, foram extremamente bem sucedidas em incidir nas conferências da ONU. A saber: Conferência das Nações Unidas sobre Meio Ambiente e Desenvolvimento (ECO 92), no Rio de Janeiro, Conferência de Direitos Humanos de Viena (1993), Conferência do Cairo (1994), Convenção de Belém do Pará (1994), Conferência de Beijing (1995). A intervenção nestes fóruns permitiu ampliar o debate racial nacional e internacionalmente, sensibilizando movimentos, governos e a própria ONU para a inclusão da perspectiva antirracista e de respeito à diversidade nos mais variados temas.

Na ECO 92, paralelamente à Conferência Oficial, organizações não-governamentais e movimentos sociais realizaram o Fórum Global 92, reconhecido pelas Nações Unidas como instância de participação da sociedade civil. O movimento de mulheres organizou o Planeta Fêmea, com seminários, reuniões, manifestações políticas e culturais, por onde passaram mais de 30 mil pessoas. A ambientalista queniana Wangari Maathai, fundadora do Green Belt Movement, vencedora do Prêmio Nobel da Paz de 2004, foi uma das conferencistas da tenda das mulheres.

Sob coordenação de Nilza Iraci e Arnaldo Xavier, Geledés e Soweto Organização Negra lançaram a publicação Há um buraco negro entre a vida e a morte, afirmando a questão racial como central para o chamado desenvolvimento sustentável. Os argumentos por eles desenvolvidos subsidiaram nossa participação na ECO 92.

O documento resultante da Conferência, a Agenda 21, demandava urgência aos governos para que ratificassem todas as convenções relativas à mulher, e o cumprimento dos procedimentos jurídicos, constitucionais e administrativos para transformar os direitos reconhecidos em leis nacionais, além da implementação de tais leis, para que as mulheres pudessem participar plenamente e em condições de igualdade nas questões e decisões relativas ao desenvolvimento sustentável.

Em 1993, Deise Benedito representou Geledés na II Conferência Mundial de 
Direitos Humanos, realizada em Viena, na Áustria. A atuação do movimento feminista foi decisiva para explicitar que mulheres e meninas também fazem parte da categoria "humano", pela inclusão do artigo 18 da Declaração de Viena:

Os direitos do homem, das mulheres e das crianças do sexo feminino constituem uma parte inalienável, integral e indivisível dos direitos humanos universais. A participação plena e igual das mulheres na vida política, civil, econômica, social e cultural, em nível nacional, regional e internacional, e a erradicação de todas as formas de discriminação com base no sexo constituem objetivos prioritários da comunidade internacional.

O debate feminista entra de vez no campo dos direitos humanos, com o reconhecimento de que o Estado não é responsável por violar direitos apenas quando tortura pessoas, mas também quando é omisso e discriminatório. A Declaração de Viena afirmou, o que ficou ainda mais explícito na Convenção Interamericana para Prevenir, Punir e Erradicar a Violência Contra a Mulher - Convenção de Belém do Pará (1994): a violência contra mulheres em esfera privada é uma questão pública. Portanto, estupro e violência doméstica deveriam ser interpretados como crimes contra os direitos humanos. Tal dispositivo abriu espaço, por exemplo, para a criação da Lei Maria da Penha, em 2006. Ainda que a lei tenha se mostrado pouco efetiva para a proteção de mulheres negras, é um marco legal importante. Entre 2003 e 2013, a taxa de homicídios entre mulheres negras aumentou $54 \%$, enquanto a de mulheres brancas diminuiu $9,8 \%$.

Em Viena, o governo brasileiro sugeriu a realização de uma conferência mundial sobre racismo e outra sobre imigração, antes do ano 2000. Chamava a atenção internacionalmente como a diplomacia brasileira parecia assumir todas as demandas da sociedade civil. Especialmente depois do Cairo, quando o Itamaraty apresentou as propostas mais avançadas no campo dos direitos humanos, incorporando definições importantes da Declaração de Itapecerica.

As mulheres negras organizadas foram para a III Conferência Internacional sobre População e Desenvolvimento, no Cairo, em 1994, com a ideia de que "em tempos de difusão do conceito de populações supérfluas, liberdade reprodutiva é essencial para etnias discriminadas para barrar as políticas controlistas e racistas". A partir do Cairo, as políticas e os programas de população deixaram de focar no controle do crescimento populacional como condição para a melhoria da situação socioeconômica dos países. A saúde reprodutiva foi considerada direito humano e elemento fundamental para a igualdade de 
gênero, e o aborto inseguro, um grave problema de saúde pública.

Também em 1994, mulheres negras representantes de dezesseis países da América Latina estiveram juntas no Foro de Mar del Plata, para preparar a Conferência de Beijing. Geledés organizou um painel com apoio da UNIFEM (Fundo de Desenvolvimento das Nações Unidas para a Mulher) e, a partir dele, produziu um documento específico das mulheres negras, em que reinvidicavam, com o objetivo de construir um projeto político plural, que a diversidade fosse o meio de alcançar níveis de desenvolvimento e de participação social e política.

No documento, pontuaram que o racismo, como forma ideológica de sustentação de um setor da população sobre o outro, é a barreira para o desenvolvimento sustentável de pessoas não brancas. Solicitaram o reconhecimento de que os países são multirraciais e multiculturais. Exigiram dos governos a implementação de políticas para saldar a dívida histórica com mulheres negras, prioritariamente, e também dados de etnia e gênero nos censos dos diferentes países.

$\mathrm{Na}$ V Conferência Mundial sobre a Mulher (Beijing, 1995), Nilza Iraci, representando Geledés, era uma das que estava com o documento em mãos, quando viram o termo étnico-racial ser retirado de um dos artigos da declaração final. Também estavam lá Wânia Sant'Anna, representando a Articulação de Mulheres Brasileiras; Fátima de Oliveira, da Rede Feminista de Saúde; Marta Oliveira, ISER - Instituto de Estudos da Religião, no papel de observadora; e a então senadora Benedita da Silva. Foi quando a diplomacia brasileira se mostrou ainda mais comprometida com o movimento social. Pela primeira vez, o Itamaraty obstruiu uma reunião do G-77, grupo dos países em desenvolvimento do qual faz parte, por discordar da retirada do termo.

A questão, inegociável para as mulheres negras brasileiras, latino-americanas, caribenhas e dos países do Norte, foi assumida com firmeza pelo Estado brasileiro, que assegurou a redação final do Artigo 32:

"intensificar esforços para garantir o desfrute, em condições de igualdade, de todos os direitos humanos e liberdades fundamentais a todas as mulheres e meninas que enfrentam múltiplas barreiras para seu desenvolvimento e seu avanço devido a fatores como raça, idade, origem étnica, cultura, religião..."

Pela primeira vez, os termos raça e etnia foram incorporados em um documento das Nações Unidas. Diante do entusiasmo das organizações internacionais com a diplomacia brasileira, Nilza Iraci e Fátima de Oliveira chegaram contando a resposta da mulherada: "Não temos problemas com o governo brasileiro nos espaços da ONU, nossos problemas só 
começam na volta”. Cumprir os acordos eram outros quinhentos.

(...)

Em 20 de novembro de 1995, 30 mil pessoas participaram da Marcha em Brasília. No ano comemorativo do tricentenário da morte de Zumbi dos Palmares, maior herói negro do Brasil, afirmaram que o 13 de maio não dizia respeito a negras e negros, e que a liberdade negra era fruto da luta de Zumbi. O dia de sua morte, dia nacional da consciência negra, era a nossa data. Depois de anos denunciando a falácia do mito da democracia racial, era o momento de exigir ações efetivas do Estado.

(...)

Da Marcha, participaram pessoas de 20 estados brasileiros, em atividades que começaram às $10 \mathrm{~h}$ da manhã e terminaram depois das $21 \mathrm{~h}$. Muitas viajaram de ônibus por três ou quatro dias. Uma delegação chegou às 19h, ao final do ato, contente por marcar presença naquele momento de articulação política ímpar do movimento negro. Os resultados da Marcha foram essenciais na formulação de políticas públicas posteriores.

Uma sessão solene do Congresso homenageou negras e negros e pautou três reivindicações: a reescrita da história da liberdade negra; a titulação de terras a remanescente de quilombos e a indenização de descendentes de pessoas escravizadas. Ao final da sessão, a Coordenação Executiva da Marcha foi recebida pelo então presidente Fernando Henrique Cardoso, para a entrega do Programa de Superação do Racismo e da Desigualdade Racial e a assinatura de um decreto presidencial instituindo um Grupo de Trabalho Interministerial (GTI) com a finalidade de desenvolver políticas para a valorização da população negra.

O documento apresentava um diagnóstico da desigualdade racial e as reivindicações estavam divididas em tópicos: educação, saúde, trabalho, religião, terra, violência, comunicação, informação e cultura. O GTI foi composto por representantes do governo e oito militantes do movimento negro, dentre os quais estava Zélia Amador de Deus, do Cedenpa - Centro de Estudos e Defesa do Negro no Pará.

Há de se reconhecer que Fernando Henrique teve coerência com sua preocupação acadêmica sobre o negro, ao menos simbolicamente. Foi o primeiro presidente na história a declarar em seu discurso de posse que havia um problema racial no Brasil e que era necessário enfrentá-lo com audácia política. No grupo de trabalho, iniciativa de seu governo, foi elaborada, em 1996, uma noção de ação afirmativa essencial à construção posterior de Durban e da política de cotas: 
“Ações afirmativas são medidas especiais e temporárias, tomadas pelo Estado e/ou pela iniciativa privada, espontânea ou compulsoriamente, com o objetivo de eliminar desigualdades historicamente acumuladas, garantindo a igualdade de oportunidade e tratamento, bem como de compensar perdas provocadas pela discriminação e marginalização, por motivos raciais, étnicos, religiosos, de gênero e outros”.

Também em 1996, FHC lançou o Programa Nacional de Direitos Humanos, pelo Decreto 1.904/96, formalmente reconhecendo os direitos humanos de "mulheres, negros, homossexuais, populações indígenas, idosos, deficientes físicos, refugiados, indivíduos infectados pelo HIV, crianças e adolescentes, policiais, prisioneiros, ricos e pobres".

Entre as propostas para combater desigualdades raciais, estavam, como medidas de curto prazo: apoio a grupos de trabalho e a criação de conselhos; inclusão do quesito cor em todos e quaisquer sistemas de informação e registro sobre a população negra e bancos de dados públicos; estímulo à presença dos grupos étnicos que compõem a população brasileira em propagandas institucionais do governo federal; apoio às ações da iniciativa privada que realizassem ações afirmativas, nomeadas como "discriminação positiva".

A médio e longo prazo, havia o compromisso de formular políticas compensatórias para promover a comunidade negra social e economicamente; alteração do conteúdo de livros didáticos; e a ampliação do acesso de entidades negras aos diferentes setores do governo. Portanto, havia espaço no Programa para a possibilidade de se instituírem ações afirmativas no ensino superior. A reação na imprensa foi imensa, com muitas acusações de "racismo às avessas" e uma defesa da igualdade jamais vista no Brasil.

(...)

Às vésperas da II Conferência Mundial Contra o Racismo, a Discriminação Racial, a Xenofobia e a Intolerância Correlata, Luiza Bairros propôs a criação de um Comitê Impulsor Pró-Conferência de Durban, formado por lideranças de organizações negras e sindicais, que assumiria as inúmeras tarefas organizativas para a atuação na Conferência mais esperada. As duas conferências mundiais sobre o racismo precedentes, de 1978 e de 1983, foram importantes para fortalecer a luta anti-apartheid e o movimento negro norteamericano. A expectativa era de que a terceira conferência fosse um incentivo ao governo brasileiro na implementação de políticas efetivas para a população negra.

Militantes do movimento negro investiram nas articulações prévias. A partir de abril do ano 2000, o Comitê realizou contatos com organizações internacionais responsáveis pela Conferência, como o International Law Group, e constituiu o Fórum Nacional de Entidades Negras para a III Conferência contra o Racismo. O Fórum elaborou uma denúncia do 
Estado brasileiro pelo descumprimento e violação sistemática da Convenção Internacional sobre Todas as Formas de Discriminação, depois, um documento sobre os efeitos do racismo no Brasil. Também formou as delegações para a participação na Conferência. Em maio daquele ano, Cidinha da Silva, representando Geledés, Edson Cardoso, como Irohin, e alguns outros brasileiros e brasileiras participaram da primeira reunião preparatória em Genebra, na Suíça. A expectativa era de que a reunião preparatória das Américas acontecesse no Brasil, mas o governo brasileiro alegou falta de recursos e a reunião foi em Santiago, no Chile.

Na conferência regional de Santiago, a ONU reconheceu afro-descendentes como vítimas do racismo. Apesar de o Brasil, tanto governo quanto sociedade civil, utilizar o termo negro, os outros países latino-americanos se recusaram a ele. Afrodescentes foi o termo negociado para designar descendentes da diáspora africana.

Dentre as mulheres, foi criada a Articulação de Organizações de Mulheres Negras Brasileiras Pró-Durban, composta por treze organizações, sob coordenação de Criola, do Rio de Janeiro; Maria Mulher, do Rio Grande do Sul e por Geledés. Internacionalmente, aproveitar a reunião preparatória das Américas, em Santiago, que aconteceu em dezembro de 2000, para convocar uma Conferência Cidadã, e fortalecer coalizões na incidência sobre as decisões na Conferência e seus preparatórios. Assim, também foi criada a Alianza Estratégica Afro-Latino-Americana y Caribenha Pró III Conferência Mundial del Racismo.

Além do Seminário intergovernamental de Genebra e da Pré-Conferência das Américas, em Santiago, aconteceram pré-conferências regionais em São Paulo, Belém e Salvador ao longo do ano 2000. E em julho de 2001, a I Conferência Nacional contra o racismo e a Intolerância. Tantos fóruns foram fundamentais para o desenvolvimento de ativistas, que chegaram bem exercitados a Durban, e também para o aprofundamento das pautas estratégicas.

O governo FHC também criou um comitê preparatório para Durban, que criou o documento levado pelo Brasil à Conferência, com a proposta da adoção de cotas ou outras medidas afirmativas para garantir o acesso de negras e negros às universidades públicas. Outra proposta era o reconhecimento da escravidão de africanos e indígenas, o tráfico transatlântico e a marginalização de seus descendentes como violações aos direitos humanos fundamentais.

O documento, aprovado por consenso, era um importante instrumento de pressão para que fossem estruturadas medidas reparatórias, por meio de política públicas de superação da desigualdade. E se o próprio governo brasileiro o levava a Durban, a aposta 
era de boas condições para que as medidas se concretizassem por aqui depois da Conferência.

Entre 31 de agosto e 8 de setembro de 2001, mais de 18 mil pessoas participaram da Conferência Mundial contra Racismo, Discriminação Racial, Xenofobia e Intolerância Correlata, em Durban, África do Sul, entre representantes da sociedade civil, dos governos, da ONU, jornalistas, trabalhadoras e trabalhadores. O Brasil, dentre os 170 países participantes, tinha a maior delegação, com cerca de 300 pessoas, somando pessoas negras e indígenas.

Na cerimônia de abertura, Kofi Annan, então secretário-geral da ONU, prêmio Nobel da Paz naquele 2001, reproduziu o slogan da luta anti-apartheid nas eleições de 1994 da África do Sul: "seksik hathi”, traduzido do zulu como "Chegou a hora!”.

Muitas manifestações aconteceram ao longo da semana. A maior foi a brasileira, com sua grande delegação, apoiadoras e apoiadores do mundo todo. O Fórum Mundial de ONGs, paralelo à Conferência oficial, teve mesa com Winnie Mandela e Angela Davis, participação de Fidel Castro, e acusação do Estado de Israel de práticas racistas e colonialistas contra o povo palestino. Israel abandonou a Conferência, seguido pelos Estados Unidos.

O clima da conferência era tenso. Questões étnicas, raciais, culturais e religiosas, e todos os problemas nos quais elas se desdobram, como racismo, discriminação racial, xenofobia, exclusão e marginalização social têm mesmo potencial para polarizar o mundo e isso ficou explícito em Durban. Apareciam oposições entre Norte e Sul, Ocidente e nãoOcidente, brancos e não-brancos e as contradições internas da maioria dos países. Carga explosiva que parecia ameaçar a aprovação do documento final.

Países europeus deixavam explícito que abandonariam a Conferência caso esta caminhasse no sentido de condenar o colonialismo e suas conseqüências. $O$ reconhecimento do tráfico transatlântico como crime de lesa-humanidade era um tema especialmente difícil. Ele poderia dar suporte a exigências de reparação, por parte de africanos e afro-descendentes, contra os países que se beneficiaram do tráfico, da escravidão e da exploração colonial africana.

Aprovar a Declaração e o Plano de Ação da Conferência, por si só, já foi uma vitória a comemorar. A escravidão e o tráfico de escravos foram considerados crimes contra a humanidade. E no documento final está a recomendação para que as nações assegurem o acesso à educação e a novas tecnologias, além de oferecer a africanos e afrodescendentes, em particular mulheres e crianças, recursos adequados à educação, ao desenvolvimento 
tecnológico e ao ensino a distância em comunidades locais. Outra recomendação é a promoção da inclusão da história e da contribuição dos africanos e afrodescendentes no currículo escolar.

As conquistas da Conferência Regional das Américas foram ratificadas, com a incorporação de parágrafos inteiros, e o termo afrodescendente tornou-se linguagem consagrada nas Nações Unidas, para designar um grupo específico de vítimas de racismo e discriminação. Foi reconhecida urgência na implementação de políticas públicas para a eliminação das desvantagens sociais de afrodescendentes, recomendando aos Estados e aos organismos internacionais, que "elaborem programas voltados para os afrodescendentes e destinem recursos adicionais aos sistemas de saúde, educação, habitação, eletricidade, água potável e às medidas de controle do meio ambiente, e que promovam a igualdade de oportunidades no emprego, bem como outras iniciativas de ação afirmativa ou positiva".

As especificidades das mulheres também foram reconhecidas, na orientação para que os Estados "reforcem medidas e políticas a favor das mulheres e jovens afrodescendentes, tendo presente que o racismo os afeta mais profundamente, colocando-os em situação de maior marginalização e desvantagens".

A agenda de Durban esteve muito além das propostas de cotas que polarizaram o debate da questão racial no Brasil nos anos subsequentes. Durban afirma a urgência de uma intervenção decisiva nas condições de vida das populações historicamente discriminadas, o que não se pode alcançar apenas com a adoção de cotas para o ensino universitário. Como Sueli Carneiro escreveu no artigo a Batalha de Durban, de 2002: "Precisa-se delas e de muito mais".

A relevância da II Conferência para a estruturação de políticas públicas no Brasil fica evidente nas inúmeras citações em documentos e programas do governo. Lideranças negras foram fortalecidas, especialmente as mulheres organizadas que construíram acordos com a representação governamental ao longo do tempo, para levar a Durban mais que denúncias, encaminhar propostas concretas de ação para o combate ao racismo. Além de toda essa importância, tantas brasileiras e brasileiros pisando solo africano conectados, causava extrema comoção.

(...)

Com a eleição de Luiz Inácio Lula da Silva, em 2003, foram nomeadas Matilde Ribeiro na equipe de transição de governo, depois no comando da Seppir, com status de ministra; Benedita da Silva, no Ministério da Assistência Social, Marina Silva no Meio Ambiente. Três ministras negras, somadas a Gilberto Gil na Cultura e nenhum outro 
governo teve tantas pessoas negras em postos de alto escalão. A Articulação de ONGs de Mulheres Negras foi convidada a compor o recém criado Conselho de Desenvolvimento Econômico e Social (CDES), um colegiado de representantes da sociedade civil, que daria assessoria direta ao presidente, qualificando a discussão de políticas públicas e a proposição de medidas para o crescimento econômico, o desenvolvimento e a equidade, e Sueli Carneiro foi como representante da entidade.

Em 2004, aconteceu a I Conferência Nacional de Políticas para as Mulheres, em Brasília, por iniciativa da Secretaria Especial de Políticas para as Mulheres. Ali, negras e indígenas inauguraram uma parceria política baseada na semelhança dos processos históricos que submeteram igualmente povos indígenas, africanos e seus descendentes.

A política entre as mulheres foi e será um campo de disputa de interesses. Houve um tempo em que as divergências pareciam irreconciliáveis, quando negras e indígenas não tinham lugar na agenda feminista, quando o conflito racial parecia insolúvel do ponto de vista político, traduzindo-se em confronto racial permanente entre as mulheres.

\footnotetext{
Em um plenário de mais de duas mil mulheres, apresentaram um documento histórico:

Firmar o nosso parentesco através de uma aliança política na busca conjunta de superação das desigualdades econômicas, políticas, sociais e culturais e de poder; firmar uma aliança estratégica para a conquista da igualdade de oportunidades para mulheres índias e negras na sociedade brasileira; firmar uma aliança estratégica que dê visibilidade a índias e negras como sujeitos de direitos. Doravante índias e negras consideram-se parentes (CARNEIRO, S., 2004).
}

Naquela I Conferência, o apoio de diferentes organizações de mulheres ao manifesto de negras e indígenas sinalizava a disposição das mulheres organizadas de trair o pacto racial excludente, construído pelo racismo, e recusar os privilégios raciais decorrentes da discriminação e exclusão social de negras e indígenas, em prol da construção da efetiva igualdade de oportunidade para todas as mulheres.

No contexto de uma conferência deliberativa para a formulação e implementação de políticas, reafirmaram que raça e etnia são, para além do gênero, elementos produtores de modalidades específicas de opressão sobre as mulheres no Brasil. São, portanto, variáveis inegociáveis no recorte das políticas públicas para a promoção da igualdade de gênero e entre as mulheres. 
Em 2005, um racha entre setores do movimento negro mais ligados a partidos e sindicatos e setores independentes culminou na realização de duas edições da Marcha Zumbi + 10: uma no dia 16, outra no 22 de novembro.

Na II Conferência Nacional de Política para as Mulheres, em 2007, as mulheres negras inscreveram o combate ao racismo, ao sexismo e à lesbofobia como elementos essenciais do combate ideológico indispensável para a promoção da igualdade de gênero e raça. Este foi o principal resultado da Conferência, eixo central do II Plano Nacional de Políticas para Mulheres.

Depois de um longo e difícil aprendizado, de décadas, havia chegado o momento de negociar politicamente a partir dos diferentes interesses e perspectivas que atravessam o movimento de mulheres. E as mulheres negras eram protagonistas. Naquele encontro, construir uma agenda coletiva de reivindicações ao Estado brasileiro que contemplava as diferentes necessidades das diferentes mulheres era o ápice do trabalho iniciado quase 30 anos antes. $\mathrm{O}$ movimento de mulheres negras tinha enegrecido o feminismo brasileiro.

O acúmulo nas Conferência e a maturidade política das organizações de mulheres negras culminou em uma proposta realizada nos bastidores do Encontro Ibero-americano do Ano Internacional dos afrodescentes, em novembro de 2011, Salvador, Bahia. Nilma Bentes, do Cedenpa, que compunha também a coordenação da Articulação das Mulheres Negras Brasileiras - AMNB, propôs levar 100 mil mulheres a Brasília em 2015, para dar visibilidade a este segmento e criar impacto para adensar o processo de eliminação das discriminações e desigualdades sociais, raciais e de gênero, denunciando o racismo, o machismo/ sexismo como pilares das desigualdades do país (BENTES; MALCHER, 2016).

A escolha de 2015 foi pautada para não coincidir com a realização da Copa do Mundo, em 2014, e as Olimpíadas, em 2016, ambas realizadas no Brasil, e por marcar os 320 anos de assassinato de Zumbi, último líder de Palmares, onde também viveram Dandara, Acotirene, Aqualtune. A mobilização foi o mais aberta possível, e o foco na metodologia era considerado mais importante que a própria realização da Marcha.

Em reunião realizada em agosto de 2014 em São Paulo, com a participação de 15 representantes de organizações de mulheres negras de todo o país, definiram como objetivo sintético:

A Marcha é, sobretudo, uma mobilização de mulheres negras, que tem por objetivo dar visibilidade à nossa existência enquanto sujeito político. Deverá enfocar questões de relevância para as mulheres negras, apresentar perspectivas das mulheres negras sobre processos e modelos mais amplos 
que impactam nossas vidas como coletivo, divulgar nossas teses e projetos de nação. Como interpretamos o atual momento e o que queremos?" (BENTES; MALCHER, 2016, p. 6)

Ao todo, cinco reuniões consultivas e de acompanhamento de conteúdo aconteceram em São Paulo, Brasília, Porto Alegre e Ouro Preto. Foi formado um Comitê Impulsor Nacional, com AMNB, FNMN, CONEN, UNEGRO, CONAQ, FENATRAD, MNU e APNs, e comitês impulsores nos diferentes estados, que elaborou os próprios panfletos de folhetos para a mobilização. Em uma dessas reuniões, Nilma Bentes propôs incorporar a noção do bem viver como concepção e proposta de futuro.

$\mathrm{Na}$ cosmologia ameríndia quéchua, a sabedoria ancestral de unicidade entre pessoas e a natureza, sem o objetivo da alienada acumulação capitalista, este fazer solidário é chamado Bem Viver. Nas palavras de Alberto Acosta (2015, p. 15), "O Bem Viver se afirma no equilíbrio, na harmonia e na convivência dos seres. Na harmonia entre o indivíduo com ele mesmo, entre o indivíduo e a sociedade e o planeta com todos os seres, por mais insignificantes ou repugnantes que possam aparentar". O Bem Viver, segundo compreenderam as mulheres em marcha, está nas comunidades indígenas latinoamericanas, mas também nos quilombos, sambas, candomblés, favelas e outras comunidades brasileiras.

O manifesto da Marcha registra:

Inspiradas em nossa ancestralidade somos portadoras de um legado que afirma um novo pacto civilizatório. (...) A sabedoria milenar que herdamos de nossas ancestrais se traduz na concepção do Bem Viver, que funda e constitui as novas concepções de gestão do coletivo e do individual; da natureza, política e da cultura, que estabelecem sentido e valor à nossa existência, calcados na utopia de viver e construir o mundo de todas(os) e para todas(os). Na condição de protagonistas oferecemos ao Estado e à sociedade brasileiros nossas experiências como forma de construirmos coletivamente uma outra dinâmica de vida e ação política, que só é possível por meio da superação do racismo, do sexismo e de todas as formas de discriminação, responsáveis pela negação da humanidade de mulheres e homens negros (MARCHA DAS MULHERES NEGRAS, 2015).

Estiveram em Brasília, mais de 50 mil mulheres negras. Dentre jovens, trabalhadoras, idosas, religiosas, ativistas, Bentes e Malcher (2016), ressaltam as presenças da sul-africana Phumzile Mlambo-Ngcuka, diretora executiva da ONU Mulheres e diversas mulheres negras reconhecidas no cenário nacional e internacional: Luiza Bairros, Matilde 
Ribeiro, Sueli Carneiro, Conceição Evaristo, Perolina Gonçalves, Zélia Amador de Deus, Benedita da Silva, Jurema Werneck, Creuza Oliveira.

$\mathrm{Na}$ avaliação de muitas das participantes, a Marcha de 2015 foi um marco significativo do poder de mobilização e articulação política das mulheres negras. Este sujeito político ganhou visibilidade neste marco histórico.

Imagem 13: Mais de 50 mil mulheres participam da Marcha das Mulheres Negras, em 18 de novembro de 2015, em Brasília

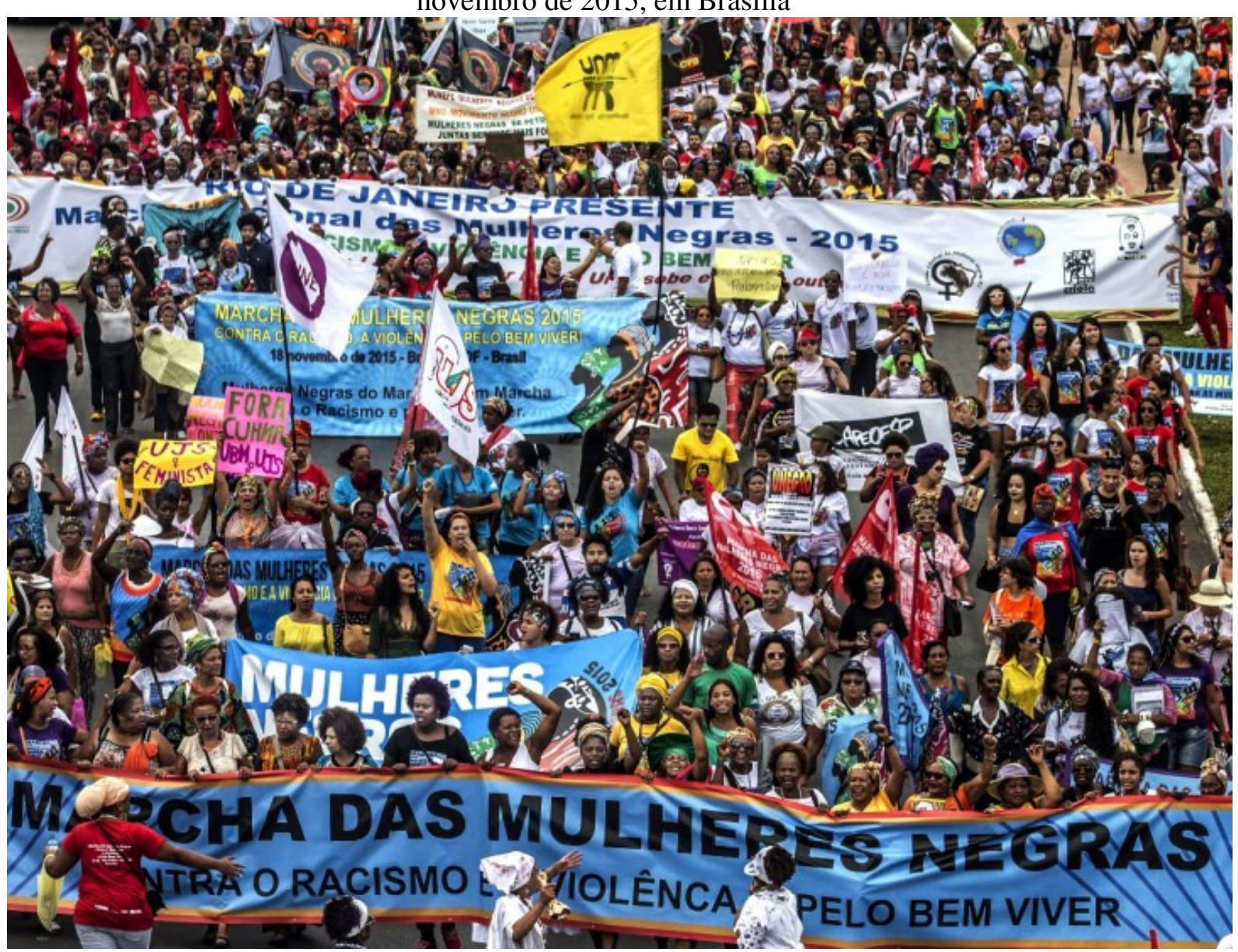

Fonte: Foto de Marcello Casal Jr / Agência Brasil

Reproduzo abaixo, o texto de avaliação de Nilma Bentes, escrito em 30 de novembro de 2015, doze dias depois da Marcha, publicado no documento organizado pelo Cedenpa (BENTES; MALCHER, 2016, p. 71) e na página web do CEERT $^{7}$ :

Às ancestrais: quinhentos anos em um dia, por Nilma Bentes Marcha das Mulheres Negras leva música e cor para Brasília

\footnotetext{
${ }^{7}$ Disponível em: <https://www.ceert.org.br/noticias/direitos-humanos/9218/as-ancestrais-quinhentos-anosem-um-dia-por-nilma-bentes $>$.
} 
Havia ameaça, mas não choveu.

O que era um tantinho de mulher negra virou um tantão e comoveu.

Lembrava um rio onde flutuavam milhares de flores coloridas.

As dezenas de faixas traziam mensagens; traduziam anseios de vidas doloridas.

As falas emocionadas alternavam com as melodias cheias de ginga e exalavam alegria.

Nem os fascista pró-ditadura empanaram ou reduziram nossa energia.

No todo, um Estado um tanto indiferente, embora um governo reticente.

Os meios de comunicação não comunicaram, omitiram, silenciaram mídia de brancos para brancos e brancas -, mas com o silêncio, não nos calaram.

Sim, mulheres negras se importam com outras e repudiam o extermínio de seus rebentos, fêmeas e machos, pela mão do Estado que é o primeiro a violar a Lei das Leis.

Nunca poderemos sair deste 'buraco' puxando-nos por nossos próprios cabelos. Algo tem de acontecer além de nossos apelos.

Capitalismo só é bom para capitalistas.

Sim, quem lá esteve sabe que o tudo que fizerem ainda será pouco, neste país encharcado de racismo e machismo; 'desnaturalizá-los`é apenas um item das listas.

A maioria das que atenderam à 'convocação' pôde fazer uma catarse racial e aliviará o coração.

Pode ter sido só cócegas no poder, mas, é sabido que quando o piso se move, a estrutura da pirâmide trinca.

E... com mulheres negras não se brinca.

Rimas pobres na língua do colonizador; não dá para roçar minha língua na língua de minha afro-etnia desconhecida por força da dor.

Crianças, adolescentes, jovens, adultas, idosas; cadeirantes, lésbicas, nãoalfabetizadas, doutoras, empregadas domésticas, professoras e todas que lá estiveram, fizeram desse 18 de novembro de 2015 um dos dias mais significativos para a luta de nossa gente negra, contra a opressão, subalternização secular.

A AMNB-Articulação de Organizações de Mulheres Negras Brasileiras e as demais organizações do Comitê Impulsor da Marcha de Mulheres Negras contra o Racismo, a Violência e pelo Bem Viver podem reivindicar a autoria desse 'atentado' em favor da democracia racial, de gênero e amplamente participativa.

Anualmente, no 25 de julho, Dia da Mulher Negra Latino-americana e Caribenha, acontecem marchas em algumas cidades brasileiras, como São Paulo, Recife e Belém. Durante o mês, em todo o país, acontecem inúmeras atividades divulgadas sob o slogan de Julho das Pretas.

Em 2018, trinta anos depois do encontro de Valença, foi realizado um Encontro de Mulheres Negras em Goiânia que ainda precisa ser digerido, relatado, registrado e analisado pelo movimento de mulheres negras. 


\section{RACISMO À BRASILEIRA}

Cabô, vinte anos de idade Quase vinte e um Pai de um, quase dois E depois das 20 horas Menino, volte pra casa! Cabô

$\hat{O}$, Neide, cadê menino?

Cabô, quinze anos de idade Incompletos seize Eram só 6 horas da tarde Cabô, cadê menino?

(Trecho da música Cabô, de Luedji Luna)

Mulheres negras recebem os menores salários, cerca de $40 \%$ do que ganham os homens brancos (MTPS, IPEA, 2016); estão mais vulneráveis ao desemprego, com 13,3\% de mulheres negras desocupadas (IPEA, 2017); mais expostas ao analfabetismo, com cerca de $10,2 \%$ das mulheres negras com mais de 15 anos de idade não alfabetizadas (IPEA, 2017); as maiores vítimas de homicídio, em que proporcionalmente são assassinadas 66,7\% mais meninas e mulheres negras do que brancas no Brasil (ONU, 2015). No estado de São Paulo, o percentual de pessoas negras que moram nas chamadas habitações subnormais (favelas, cortiços, palafitas, loteamentos clandestinos e/ou irregulares) é de 60,66\% (IBGE, 2010). A cada 23 minutos um jovem negro é assassinado no Brasil (SENADO FEDERAL, 2017).

Sem nenhuma lei de segregação racial, como tiveram os Estados Unidos e a África do Sul, o racismo estrutura a sociedade brasileira e priva pessoas negras do acesso a direitos, inclusive do direito à vida. Esse mecanismo complexo que, de forma muito azeitada, nas palavras utilizadas por Sueli Carneiro em uma de nossas entrevistas, faz um caminho para matar, outro para subjugar e assim organiza todo o saber, o poder, a produção de sujeitos hegemônicos e subalternos no Brasil.

Além de referência teórica principal, Sueli Carneiro e sua obra serão também fio condutor das reflexões desenvolvidas nesse capítulo. Aos 49 anos de idade, em 1999, depois de duas tentativas de mestrado ainda nos anos 1980, Sueli Carneiro voltou à pósgraduação com o objetivo de descrever o mecanismo complexo do racismo à brasileira. 
Orientada por Roseli Fischmann, no programa de Filosofia da Educação, na FE-USP, ingressou no mestrado em 1999, mas, na banca de qualificação, foi impelida ao doutorado direito.

Não havia nada que Sueli Carneiro quisesse investigar, além da aplicação dos conceitos de dispositivo e de biopoder, de Foucault, ao domínio das relações raciais. Quase 20 anos antes, em 1984, havia exercitado a investigação em um fluxograma entregue como trabalho final de uma disciplina de pós-graduação da FFLCH ao professor José Augusto Guilhon de Albuquerque. Em quatro partes - do dispositivo; do preenchimento estratégico; do saber/poder; da resistência -, Sueli Carneiro relacionou trechos de notícias de jornais e informações coletadas no ativismo a palavras-chaves que explicitam a teoria de Foucault. Naquela síntese esquemática das articulações entre saber, resistência e raça como efeitos de poder do racismo e da discriminação racial, estava subsumida a ideia de um dispositivo de racialidade, mas não estava nomeada.

Era evidente para Sueli Carneiro que todos os atributos definidos por Foucault para o termo dispositivo estavam presentes nas relações raciais, e nas relações de poder delas derivadas. Utilizaria o repertório conceitual dos dispositivos de Foucault para trabalhar o tema da racialidade tal como ele se apresenta no Brasil, para, então, apresentar o conceito de dispositivo de racialidade. Também partiria da ideia do biopoder para a compreensão da política de morte de negras e negros. Sueli Carneiro não sabia que, no mesmo período, Achille Mbembe trabalhava a mesma ideia, nomeada como necropolítica, publicada como ensaio em 2003.

Sua intuição indicava que Foucault oferecia uma boa caixa de ferramentas, nos moldes do que Deleuze havia dito ao próprio Foucault em 1972, conforme publicado em $A$ microfísica do poder: "Uma teoria é como uma caixa de ferramentas. Nada tem a ver com o significante... É preciso que sirva, é preciso que funcione. E não para si mesma. "Dispositivo e biopoder funcionariam para compreender o racismo, em termos e formatos aceitáveis na Universidade.

$\mathrm{Na}$ introdução do trabalho, único pedaço de liberdade para um texto mais solto e autoral, Sueli Carneiro brincou com a escolha, dirigindo-se à banca e a possíveis leitores da academia:

Para esse árduo trabalho para o qual te convido precisamos de ajuda. Então, convoquei Michel Foucault, sim, o francês. Sei que ele é um sujeito da tua confiança e goza também de minha simpatia. É um mediador razoavelmente confiável para as nossas possíveis contendas. Por 
ser um elemento de fronteira, ele conversa bem com todo mundo, seja um ser-aí, ou coisas-ente. Mas, embora simpático, ele é um tipo rigoroso e exige regras para essa arbitragem, para que nosso debate não seja improdutivo ou para evitar que ele fique à mercê de nossas paixões, embora o seu racionalismo mantenha as tuas sob controle, nunca se sabe, estes assuntos dos quais vamos tratar costumam fazer irromper forças irracionais, naturais para mim, mas que podem te surpreender (CARNEIRO, S., 2005, p. 22-23).

Foucault também ajudava a não precisar passar por aquele monte de bibliografia que de nada a interessava. Ele é um filósofo que não se coloca em harmonia com outros facilmente, então Sueli Carneiro poderia ir direto ao dispositivo e especular com Foucault, na forma mais pura de filosofar, utilizando pontualmente autoras e autores que de fato fizessem sentido.

Sueli Carneiro organizou o texto final da tese intitulada A construção do outro como não-ser como fundamento do ser em três partes: na primeira, Poder, saber e subjetivação, apresenta e especula o referencial teórico. Demonstrou que no período pós-abolição se configurou no Brasil um dispositivo de racialidade encarregado de estabelecer a nova configuração social do projeto de modernização do país que se beneficiava das representações produzidas sobre o negro antes e durante o período colonial.

E então convocou um outro autor: o afro-jamaicano Charles Mills, que, segundo Sueli Carneiro me explicou em uma entrevistas "trabalha a teoria mais cara da ciência política, a do contrato social, para tratar de temas estratégicos para a humanidade, mas totalmente ausentes da filosofia política: racismo, colonialismo, território, identidade". Com a noção de contrato racial emprestada de Mills, Mostra como o dispositivo de racialidade se constitui, antes de tudo, em um contrato entre brancos, fundado na cumplicidade em relação à subordinação social e na eliminação de negros e não-brancos. Uma articulação de técnicas disciplinares derivadas do dispositivo de racialidade e de eliminação informadas pelo biopoder.

Então destaca do interior dessa unidade analítica, conformada pelo dispositivo de racialidade e biopoder, o epistemicídio. A partir de Boaventura Sousa Santos e bell hooks demonstra as estratégias de inferiorização intelectual do negro e sua anulação como sujeito de conhecimento, ao se consolidar a supremacia intelectual da racialidade branca.

A segunda parte da tese, Das Resistências, foi a mais difícil de resolver. A intenção de Sueli Carneiro era apresentar pessoas que sintetizam a articulação de trajetórias individuais de mobilidade e sucesso com a condição de sujeitos coletivos de uma luta de emancipação. Na trajetória de cada sujeito estaria a busca de superação dos mecanismos do 
dispositivo de racialidade negro e o que cada uma delas sinalizava como tática de resistência e ruptura com as estratégias de subordinação do dispositivo de racialidade e de sobrevivência ao biopoder.

Edson Cardoso, Sônia Maria Pereira Nascimento, Fátima Oliveira e Arnaldo Xavier. Dois homens e duas mulheres, dois negros de pele clara e dois de pele escura, que encarnaram em suas vidas a memória ancestral, o processo tortuoso de construção da identidade, os enfrentamentos com o racismo e a discriminação, a tomada de consciência individual e da dimensão política e coletiva desse processo, a construção da crítica e da autonomia. Mas como trazê-los à tese? Sueli Carneiro jamais poderia tratá-los como objetos. Era imenso o desafio de trabalhar com depoimentos sem reproduzir posicionamentos metodológicos que, voluntária ou involuntariamente, transformam intelectuais negros insurgentes em mera fonte primária de pesquisa, abandonando e mesmo rejeitando seu estatuto de autoridades do saber sobre si mesmos.

Como escreveu na tese, em nota de rodapé:

Trata-se também, aqui, da estrita observância de um princípio foucaultiano tal como ele é atribuído a Foucault por Deleuze no âmbito do livro Microfísica do poder. Deleuze considera que Foucault foi: ‘(...) o primeiro a nos ensinar - tanto em seus livros quanto no domínio da prática - algo de fundamental: a indignidade de falar pelos outros (CARNEIRO, S., 2005, p. 152).

A solução encontrada foi transformar cada um deles em um capítulo, elevando os depoimentos a testemunhos, conforme as tradições alemã e latino-americana têm desenvolvido nas teorias do testemunho. Sueli Carneiro trabalha com escritos de Márcio Seligmann-Silva, professor da Unicamp, que elabora a noção de testemunho, desafio à linguagem e apresentação da unicidade radical das tragédias e catástrofes. Ele fala sobre a unicidade da Shoah, do holocausto, e Sueli Carneiro da unicidade radical da escravização negra e do racismo. Os sobreviventes são porta-vozes e esta foi a justificativa metodológica para os testemunhos. Nesta abordagem teórica, em sua percepção, pode tratá-los com o devido respeito e reconhecimento como portadores da autoridade da fala sobre as relações raciais.

Edson Cardoso, militante histórico do movimento negro dedicado à agitação e propaganda, como gosta de dizer, atuou sempre na articulação política, formação e circulação de informação. Foi membro do MNU, assessor parlamentar no Congresso e esteve à frente da organização da Marcha Zumbi dos Palmares, pela Cidadania e pela Vida 
de 1995, e da articulação que criou o Comitê Impulsor para Durban. Era mestre em comunicação social e ainda não havia ingressado no doutorado em educação na USP, que defenderia em 2009. Sônia Maria Pereira Nascimento, advogada especialista em direito de família, direitos humanos e de mulheres. Foi presidenta de Geledés por dois mandatos, depois coordenadora executiva, responsável pelo programa PLPs (Promotoras Legais Populares) e, naquele momento, pelo atendimento de mulheres vítimas de violência.

Fátima Oliveira era médica, militante feminista e anti-racista, autora especialista nas áreas de direitos reprodutivos e da saúde da população negra. Pioneira nos estudos de genética e bioética de uma perspectiva feminista e anti-racista. Em 2017, morreu em decorrência de um câncer. Arnaldo Xavier, poeta, publicou inúmeros poemas, em português, francês e alemão, além de peças de teatro. Seu testemunho foi publicado na tese in memorian.

Por mais de dez anos, o capítulo 3, do Epistemicídio, parece ter sido o mais bem compreendido de toda a tese e também o mais citado. Por mais que vez ou outra Sueli Carneiro tivesse notícia de que alguma disciplina ou grupo de pesquisa estivesse utilizando a tese, as citações mais frequentes eram sobre o epistemicídio. Sueli Carneiro conviveu por anos com a impressão de que a tese precisaria ser reescrita para que as pessoas compreendessem as relações mais complexas propostas no trabalho.

Mas nos últimos anos, principalmente depois das eleições de 2018, muitas pessoas pareceram se apropriar da tese como um todo. Talvez a campanha eleitoral e ações de governo explicitamente racistas tenham dado materialidade ao que parecia muito especulativo ou distante. Se antes, Sueli Carneiro havia recebido notícia de apenas uma disciplina de pós na UNB utilizando a tese, de repente havia outras na USP, UFRJ, Federal de Goiás, Alagoas e Rio Grande do Sul. Curso de extensão em universidade, grupos de leitura dentro e fora da academia, também em círculos ativistas. Nunca ter publicado a tese em livro, mesmo depois de ter sido incentivada por figuras como Luiza Bairros, que chegou a trabalhar uma versão menos densa do texto para ampliar as possibilidades de circulação, passou a ser motivo de questionamento. 


\section{Dispositivo de racialidade e contrato racial}

No sertão da minha terra, fazenda é o camarada que ao chão se deu

Fez a obrigação com força, parece até que tudo aquilo ali é seu

Só poder sentar no morro e ver tudo verdinho, lindo a crescer

Orgulhoso camarada, de viola em vez de enxada

Filho do branco e do preto, correndo pela estrada atrás de passarinho

Pela plantação adentro, crescendo os dois meninos, sempre pequeninos

Peixe bom dá no riacho de água tão limpinha, dá pro fundo ver

Orgulhoso camarada, conta histórias pra moçada

Filho do senhor vai embora, tempo de estudos na cidade grande

Parte, tem os olhos tristes, deixando o companheiro na estação distante

Não esqueça, amigo, eu vou voltar, some longe o trenzinho ao deus-dará

Quando volta já é outro, trouxe até sinhá mocinha pra apresentar

Linda como a luz da lua que em lugar nenhum rebrilha como lá

Já tem nome de doutor, e agora na fazenda é quem vai mandar

E seu velho camarada, já não brinca, mas trabalha

(Morro Velho, de Milton Nascimento)

Racialidade, para Sueli Carneiro, é uma noção relacional. Diz respeito à interação de grupos racialmente demarcados, sob os quais pesam concepções histórica e culturalmente construídas. Discursos e práticas produzidos em torno da racialidade se configuram como dispositivo de poder, em que os pólos dessa interação - brancos e negros -, incorporam determinados valores culturais, privilégios ou prejuízos. Dispositivo de racialidade, portanto, diz respeito ao domínio que produz e articula saberes, poderes e modos de subjetivação nas relações raciais. 
No marco teórico da noção de dispositivo, de Foucault, conforme afirma Sueli Carneiro, há determinados atributos essenciais ao Ser e ao Outro. "Temos em Foucault um eu que é dotado de razoabilidade, porque produziu o louco; de normalidade, porque produziu o anormal; e de vitalidade, porque inscreveu o Outro no signo da morte" (CARNEIRO, S., 2005, p. 42). Em sua tese, Sueli Carneiro afirma que esse Ser (eu) no encontro com a racialidade adquire superioridade pela produção do inferior, pelo agenciamento que esta superioridade produz sobre a razoabilidade, a normalidade e a vitalidade. "Podemos afirmar que o dispositivo de racialidade também será uma dualidade entre positivo e negativo, tendo na cor da pele o fator de identificação do normal, e a brancura será a sua representação. Constitui-se assim uma ontologia do ser e uma ontologia da diferença, posto que o sujeito é, para Foucault, efeito das práticas discursivas" (CARNEIRO, S., 2005, p. 42).

O dispositivo é uma ferramenta analítica, composta por ditos e não ditos. Assim, discursos, instituições, arquiteturas, leis, medidas administrativas, enunciados científicos, mitologias compõem o dispositivo. Duas leis específicas que antecederam a abolição me parecem interessantes para observar a conformação do dispositivo de racialidade, que produziu e segue produzindo um sistema de supremacia e subordinação racial.

A maior sinalização de que a abolição legal estava a caminho, mesmo que demorasse ainda 38 anos para ser assinada, foi a Lei Eusébio de Queirós, de 1850. Como é praxe no Brasil, o fim da escravidão legal seria lento, gradual e seguro para os proprietários. A lei colocou fim, ao menos no papel, no tráfico transatlântico de pessoas escravizadas, e isso muitas pessoas sabem. O que me parece pouco difundida é a informação de que duas semanas depois da Lei Eusébio de Queirós, foi assinada a Lei de Terras (Lei $\mathrm{n}^{\mathrm{o}}$ 601, de 18 de setembro de 1850), que definia, em seu artigo primeiro:

Ficam proibidas as acquisições de terras devolutas por outro titulo que não seja o de compra.

A medida impedia a concessão ou a posse de terras a lavradores, mesmo que não fossem mais escravizados. O Ser já era proprietário de terras. O Outro, mesmo liberto, não seria.

O legislar sobre as relações raciais está explícito em dois artigos da Lei de Terra, para os quais só atentei nesta pesquisa (Brasil, 1850):

Art. 17: Os estrangeiros que comprarem terras, e nellas se estabelecerem, ou vierem á sua custa exercer qualquer industria no paiz, serão 
naturalisados querendo, depois de dous annos de residencia pela fórma por que o foram os da colonia de $\mathrm{S}$, Leopoldo, e ficarão isentos do serviço militar, menos do da Guarda Nacional dentro do municipio.

Art. 18. O Governo fica autorizado a mandar vir annualmente á custa do Thesouro certo numero de colonos livres para serem empregados, pelo tempo que for marcado, em estabelecimentos agricolas, ou nos trabalhos dirigidos pela Administração publica, ou na formação de colonias nos logares em que estas mais convierem; tomando anticipadamente as medidas necessarias para que taes colonos achem emprego logo que desembarcarem.

Aos colonos assim importados são applicaveis as disposições do artigo antecedente.

A Lei de Terras estava em debate havia mais de uma década. Em 1842, um parecer do Conselho de Estado sobre colocar um fim à doação de terras para trabalhadores livres estrangeiros havia determinado:

Como a profusão de datas de terras tem, mais que outras causas, contribuído para a dificuldade que hoje se sente de obter trabalhadores livres, é seu parecer que de ora em diante sejam as terras vendidas sem exceção alguma. Aumentando-se, assim, o valor das terras e dificultandose, consequentemente, a sua aquisição, é de esperar que o imigrado pobre alugue o seu trabalho efetivamente por algum tempo, antes de obter meios de se fazer proprietário (Parecer, 1842 apud MENDES, 2009).

Ou seja, o Ser, mesmo que estrangeiro e pobre, é trabalhador livre incentivado a passar alguns anos em grandes propriedades rurais, quando pode poupar recursos suficientes para a compra de suas terras, e consequente acesso à cidadania brasileira, se assim desejar. O Outro, por oposição ao texto legal e observação empírica, não tem emprego, nem outra fonte de recursos para a compra de terras, e tem sua cidadania constantemente negada.

Toni Morrison, ao escrever sobre a sociedade norte-americana, afirma que, na chegada de imigrantes europeus aos Estados Unidos, entre 1890 e 1920 - judeus do Leste, católicos do Sul, os brancos anglo-saxões e protestantes -, diante das "infusões de sangue estrangeiro", acabaram por nomear as diversas etnias europeias também como parte da hegemonia branca. Para se tornarem americanos, precisavam abraçar - ou forjar - sua brancura. (MORRISON, 2019, p. 39-40). É possível dizer o mesmo sobre os variados tons de pele e origens étnicas de italianos, portugueses ou espanhois do Sul da Europa, no contrato racial brasileiro, todos assinaram como brancos.

Repito que o dispositivo é uma ferramenta analítica composta por leis, arquiteturas, discursos, mitologias e também não ditos. Em uma das entrevistas na casa de Sueli 
Carneiro para a escrita de sua biografia, em maio de 2018, ela mencionou uma crônica de Lima Barreto, em que ficaria muito explícita a possibilidade de, no Brasil, o Ser branco, ir e vir sem ser molestado; enquanto o Outro, negro, precisa sempre parar nas barreiras, apresentar credenciais, sob o risco de interdição, mesmo que isso não esteja escrito ou verbalizado.

O trecho mencionado por Sueli Carneiro está no Diário Íntimo, de Lima Barreto (BARRETO, L., 1961). Ao final de muitos episódios narrados em 24 de janeiro de 1908, ele escreve: "Fui a bordo ver a esquadra partir. Multidão. Contato pleno com meninas aristocráticas. Na prancha, ao embarcar, a ninguém pediam convite; mas a mim pediram. Aborreci-me. Encontrei Juca Floresta. Fiquei tomando cerveja na barca e saltei. É triste não ser branco".

Mesmo em casos de a lei, o dito, reprimir discriminações raciais, os não-ditos do sistema de justiça operam de forma eficiente. No Brasil, somente em 1951 a discriminação racial se tornou contravenção penal, com a Lei 1.390/51, conhecida como Lei Afonso Arinos. O mito da democracia racial estava em seu auge, e mesmo assim o Estado brasileiro reconheceu a existência do preconceito e da discriminação.

Em seus nove artigos a lei listava a recusa de negação de oferta de serviços de estabelecimentos comerciais e de ensino, de hospedagem, venda, entrada em locais públicos, acesso ao funcionalismo público ou ao mercado de trabalho por preconceito de raça e cor como contravenções. As punições variavam do pagamento de multa, suspensão ou perda de cargo, a prisão, entre 15 dias e um ano. Esteve em vigor até 1985, quando foi substituída pela Lei $n^{\circ} 7.437 / 85$, em vigor até 1989, que ampliava as contravenções penais não apenas à prática de atos resultantes de preconceito de raça e de cor, mas também de sexo ou de estado civil (SANTANA, B., 2020).

Em todo o estado de São Paulo, de 1951 a 1988, apenas um processo criminal foi executado com fundamento na lei Afonso Arinos, e nenhum fundamentado na nova redação, de 1985. O primeiro projeto coordenado por Sueli Carneiro em Geledés - Instituto da Mulher Negra, chamado SOS Racismo, foi criado depois de uma pesquisa coordenada por ela que constatou a ineficácia da Lei. Em uma entrevista, Sueli Carneiro me disse que apenas um caso havia sido julgado, mas encontrei um artigo publicado nos anos 1990, que fazia menção a dois casos. Em 2019, na escrita de sua biografia, refiz a pesquisa no Tribunal de Justiça de São Paulo e, desde 1951 até 1988, em 37 anos, foi encontrado apenas um julgado com a aplicação da Lei Afonso Arinos e nenhum com a lei que a substituiu, em todo o estado de São Paulo. 
Em 1973, na cidade de Barra Bonita, um segurança impediu a entrada de um homem negro em um baile do Vila Nova Futebol Clube. A vítima procurou a delegacia de polícia alegando ter sido barrado por ser uma "pessoa de cor". Uma testemunha afirmou que o segurança impediu a entrada com a justificativa de que o homem "era preto". Foi instaurado processo de contravenção penal, o segurança foi preso e teve seu processo de habeas corpus negado.

Pesquisas sobre a lei Afonso Arinos não indicam um cenário muito diferente no restante do país. Apesar da importância simbólica, de o Estado brasileiro ter reconhecido o preconceito e a discriminação racial, a lei se tornou conhecida por sua inefetividade. Além de a maior parte dos atos discriminatórios não serem tão ostensivos quanto nas situações previstas, há de se considerar a pouca disposição das autoridades em levar adiante processos criminais deste tipo, a própria relutância das vítimas em registrar ocorrências, o acesso dificultado a orientações legais e à contratação de advogadas ou advogados, e também o despreparo de profissionais do direito para lidar com o racismo. Não-ditos que compõem o dispositivo de racialidade.

Como Sueli Carneiro já disse e escreveu, no Brasil se produziu a forma mais sofisticada e perversa de racismo do mundo porque nosso ordenamento jurídico assegurou uma igualdade formal, com uma suposta igualdade de direitos e oportunidades, e liberou toda e qualquer forma de discriminação racial. Até 1951 o racismo não era, sequer, contravenção penal. E quando uma lei foi aprovada, ficou apenas no papel.

No artigo $5^{\circ}$ da Constituição Cidadã, como já mencionado anteriormente, o racismo foi definido como crime inafiançável e imprescritível. Mas, diante da inefetividade da Lei Afonso Arinos, organizações do movimento negro têm se dedicado a fazer que a lei seja aplicada. Em Geledés - Instituto da Mulher Negra, inspiradas na organização francesa SOS Racisme, Sueli Carneiro e suas companheiras criaram o SOS Racismo de Geledés, articulado como seção brasileira do projeto internacional. Em dezembro de 1987, o IPCN Instituto De Pesquisa Das Culturas Negras, já havia inaugurado o primeiro SOS Racismo do Brasil, no Rio de Janeiro.

Como se pode ler na biografia de Sueli Carneiro (SANTANA, B., 2020), o projeto inaugurou o Programa de Direitos Humanos de Geledés. O objetivo geral era redimensionar a problemática racial, colocando-a no âmbito dos direitos humanos fundamentais. Naquele momento, as entidades que conformavam o campo dos direitos humanos estavam particularmente voltadas aos abusos da ditadura militar. A violação de direitos da comunidade negra não era sequer considerada. Direitos humanos só passaram a ser 
reivindicados no Brasil quando brancos, o Ser, começaram a sofrer tortura, acusados de comunistas.

No capítulo 6 da tese de Sueli Carneiro (2005, p. 191), é apresentado o testemunho da advogada Sonia Maria Pereira Nascimento, uma das fundadoras de Geledés, sobre os atendimentos jurídicos que realizada no SOS Racismo:

Quando assumi, eu não imaginava a dimensão do problema, do drama. No começo era muito dolorido, eu chorei com muitas vítimas. (...) casos como consumidores confundidos com ladrões, em lojas em que a pessoa era barrada na saída. (...) Aconteceu na loja Zelo da rua 25 de Março. A moça entrou, tinha em mãos uma sacola lacrada, com uma toalha que tinha comprado na loja ao lado, procurou e não encontrando o que buscava, saia da loja quando o segurança pegou-a e conduziu para a tal salinha, abriu a sacolinha lacrada, viu a toalha, deu para o vendedor para localizar de que local ela havia furtado, só que não tinha aquele tipo de toalha na loja Zelo, sabe o que ele fez? Jogou a toalha nela e disse: 'Então vai embora vagabunda'. E lhe deu murro no rosto e a jogou para fora da loja, você acredita? Ela caiu, uma pessoa socorreu, e falou: 'vamos prá polícia', tinha uns guardas passando numa pracinha próxima que comunicados foram até a loja onde, claro, eles desmentiram, os policiais perguntaram se ela queria fazer alguma coisa, mas já dizendo que eles eram de loja e ela sozinha, para pensar bem. Deixou por isso mesmo. Então, ela tomou um táxi para ir embora e contou para o motorista e ele disse para ela ir para a delegacia, pois deveria processar a loja. Foram, o delegado mandou um investigador com ela e na loja eles contaram outra história. Os policiais estavam passando por lá, ela os apontou e eles foram chamados e confirmaram que foram chamados mas que ela se negou a ir até a delegacia e o taxista também falou ao investigador que era muita gente a passar por aquilo por isso ele a levou até a delegacia para ver se isso acaba. $\mathrm{O}$ investigador perguntou se tinha tido briga na loja, eles responderam que não, 'então porque ela está com este hematoma?', ele perguntou. Bem, a Zelo foi processada e condenada a pagar uma indenização. (...) Outro foi o caso da mulher negra que tinha uma rotisseria num bairro classe média alta, que a mulher branca foi comprar um produto e não gostando começou a xingar de preta suja e que aquele não era local para pretos. (...) Assim também foi o caso do condomínio: nós recebemos uma reclamação de uma senhora de 70 anos que foi discriminada em seu apartamento no condomínio onde morava, entrou uma síndica nova, e colocou na porta dela que macacos não podiam morar no prédio.

Os atendimentos no Programa inaugurado em 1991 eram sempre feitos por advogadas ou advogados negros que compreendiam e acolhiam as vítimas, e conheciam bem o sistema de justiça e o arcabouço legal para tratar da temática racial. O SOS Racismo foi a principal referência da população negra de São Paulo para questões de natureza jurídicas e talvez isso explique a demanda elevada, durante a década de 1990, de aproximadamente 200 casos atendidos por ano. Os casos concretos permitiram criar 
subsídios para mais um amparo legal, de modificar o artigo 140 do Código Penal e incluir a figura penal de injúria racista (PL 1.240-A/ 1995), com o objetivo de facilitar a punição de racismo por insultos, e também, a partir do ano 2000, levar casos negligenciados pelo sistema de justiça brasileiro à corte internacional.

Um caso, contado em detalhes na biografia, que reproduzo abaixo, é ilustrativo para compreender como, apesar de o racismo ser crime previsto na Constituição, o sistema de justiça brasileiro opera na proteção do Ser que praticou o racismo, negligenciando as denúncias do Outro, mesmo que amparado legalmente.

Em março de 1988, um anúncio de vagas para representantes comerciais na empresa NIPOMED - Planos de Saúde, foi publicado da Folha de S. Paulo. Isabel Lazzarini se interessou pela vaga e também compartilhou a informação com sua colega de trabalho Neusa dos Santos Nascimento. Isabel é branca. Neusa, negra. Elas iriam juntas à empresa, mas não encontraram uma agenda comum. Então Neusa convidou uma outra amiga, também negra, Gisele para ir com ela e foi informada de que não havia mais vagas, todas teriam sido preenchidas.

Horas depois, sem ter falado com a amiga, Isabel foi ao mesmo local, e, atendida pelo mesmo homem, recebeu uma ficha, respondeu perguntas e recebeu o material para começar a trabalhar. Para completar, o recrutador perguntou se ela tinha outras pessoas com as mesmas características para indicar. Gisele voltou à empresa, foi atendida por outro homem que pediu para preencher a ficha e aguardar um contato, que nunca aconteceu.

Neusa e Gisele foram à delegacia de polícia, registraram a ocorrência e procuraram o SOS Racismo, que levou o caso à justiça. O ministério público denunciou o recrutador com base no artigo $4^{\circ}$ da Lei Caó, que configura como crime de racismo "negar ou obstar emprego em empresa privada". Isabel, a amiga branca, foi testemunha de acusação e confirmou todos os fatos, o que permitiu a ação penal, apesar de o réu ter negado a acusação. O juiz julgou a ação improcedente com a seguinte justificativa: "resta dúvidas a respeito da verdadeira conduta do réu”. Também afirmou que não era possível demonstrar a real intenção do acusado. Entraram com recurso de apelação em novembro de 1999, receberam a apelação do réu em março de 2000, e até dezembro de 2003 o caso não havia sido distribuído no Tribunal de Justiça do Estado de São Paulo. A empresa fechou e ninguém mais sabia do réu.

Rodnei Jericó, atual advogado responsável pelo SOS Racismo, protocolou uma denúncia à Comissão Interamericana de Direitos Humanos (CIDH), alegando que o Estado Brasileiro assumiu o compromisso com a garantia de direitos individuais celebrados na 
Convenção Americana de Direitos Humanos no seu artigo primeiro, e havia violado o direito de igualdade perante a lei. Não foi respeitado o artigo 3, que diz respeito à obrigação de não discriminação; o 6, que confere o direito ao trabalho; e o 7, sobre condições justas, equitativas e satisfatórias de trabalho, todos do Protocolo Adicional à Convenção Americana de Direitos Humanos Econômicos, Sociais e Culturais - Protocolo de San Salvador.

E assim seguiu, por dezenas de páginas, até pedir que o Estado Brasileiro fosse intimado pela CIDH a se manifestar, que fizesse uma investigação, julgasse e punisse criminalmente os responsáveis, além de obrigá-los a pagar indenização às vítimas. $\mathrm{O}$ Estado respondeu em outras muitas páginas que a denúncia não deveria ser acatada pela Comissão porque o advogado não havia cumprido os requisitos necessários ao recurso, porque a CIDH não poderia condenar o Estado por determinados artigos e convenções, porque não haviam se esgotado os recursos na justiça brasileira, porque não havia demora no julgamento. A Comissão julgou a denúncia admissível, mas o mérito, o conteúdo do caso, ainda não foi julgado. Desde 2003.

O dispositivo de racialidade, ao demarcar o ser branco como estatuto humano, redefine todas as demais dimensões humanas e as hierarquiza de acordo com a proximidade ou distanciamento do padrão brancos. Este processo inscreve negras e negros em um paradigma de inferioridade em relação aos brancos.

Saindo dos exemplos legais, vamos a uma escola. Em um caso que envolve a mitologia iorubá. Por mais complexa e rica que seja, conforme demonstrado anteriormente, não ocupa um décimo da centralidade que a mitologia grega, por exemplo, ocupa no imaginário social brasileiro, no que é ensinado nas escolas ou nas referências constantes em diversas áreas do conhecimento. Até a mitologia celta é mais difundida e respeitada. E quando há um esforço em trazer mitologias negras para cumprir, por exemplo, recomendações legais do ensino de história e cultura africana e afro-brasileira em escolas, gera espanto e reações adversas. Até 2018, meus três filhos estudavam em uma escola sócio construtivista, de classe média alta, em São Paulo, frequentada por intelectuais, artistas e pessoas consideradas progressistas.

Gostamos muito da escola, que conta com profissionais dedicados, competentes e verdadeiramente comprometidos com a reflexão crítica e uma educação libertária. Em uma noite do pijama, em vez da fada, da mitologia celta, estar representada no parquinho, com o desafio de as crianças encontrarem estrelas coloridas para presenteá-la, o grupo de professoras, lideradas por uma professora especialmente sensível à temática racial, 
colocaram uma Iemanjá, linda e preta bem no centro. As crianças precisavam procurar conchinhas no parque para presentear o orixá. Uma das mães procurou a professora muito preocupada com o fato de a escola evocar símbolos religiosos. Com toda a paciência, a professora explicou que não se tratava de religião, mas de mitologia. Assim como a mitologia celta oferecia arquétipos interessantes para a educação infantil, a mitologia iorubá também oferecia. A fada, símbolo do Ser. Iemanjá, símbolo do Outro.

Sueli Carneiro testa cada uma das regras definidas por Foucault para uma analítica do poder: a regra da imanência; a regra das variações contínuas; a regra do duplo condicionamento; e a regra da polivalência tática dos discursos (Foucault, 2001, p. 93-80 apud CARNEIRO, S., 2005, p. 32). Da regra da imanência decorre que todo poder institui um campo de saber e todo saber é expressão de uma dimensão de poder. Sobre a regra das variações contínuas Foucault afirma que as relações de poder-saber são matrizes de transformações, ou seja, os discursos se renovam continuamente.

Com relação à regra do duplo condicionamento, uma estratégia é condicionada por táticas específicas, e as táticas, por sua vez, funcionam graças ao invólucro da estratégia, em uma interação contínua. Sobre polivalência tática dos discursos: o mesmo discurso que produz poder, também o mina e o barra; assim como o silêncio e o segredo podem dar ou tirar poder. Cada uma dessas regras está presente no dispositivo de racialidade. Dentre essas regras, Sueli Carneiro afirma que talvez a que melhor atenda à compreensão das relações raciais no Brasil seja a da polivalência tática dos discursos, em que "os silêncios têm lugar privilegiado, em particular na definição de interdições” (CARNEIRO, S., 2005, p. 33).

Dialogando com a perspectiva genealógica de Foucault, de investigar as origens e também a finalidade, Sueli Carneiro pontua uma inflexão histórica na origem do dispositivo de racialidade: o contrato racial, tal como definido pelo filósofo afro-jamaicano Charles Mills. "O que se constitui em história é, em Foucault, aquilo que se encontrou com o poder" (CARNEIRO, S., 2005, p. 49). A partir do século XV, com as expedições de conquistas e dominação europeia, há a configuração de uma nova tríade de poder, saber e subjetividades, informada pela racialidade, que conforma homens, nativos; brancos, nãobrancos. Gradualmente, se consolida uma supremacia branca, estruturada por um contrato racial. "Mills irá sustentar esta concepção no diálogo com as teorias contratualistas consagradas pela filosofia política, em que a noção de contrato social constitui, para ele, a possibilidade teórica de empreender a conexão entre as teorias políticas dominantes e as questões postas pelo tema da racialidade" (CARNEIRO, S., 2005, p. 47). 
O contrato racial, ferramenta normativa relacionada a questões de respeito e justiça, é firmado entre iguais, e os desiguais são subjugados por meio da violência. O Estado teria, então, o papel de manter e reproduzir a ordem racial, assegurando privilégios a brancos e mantendo a subordinação dos não-brancos, tanto pela lei como pelos costumes.

Ao propor esta noção, Mills se utiliza do contratualismo, tema caro da filosofia política, para tratar de temas praticamente ignorados por ela, como colonialismo, colonização branca, direitos sobre a terra, raça e racismo, escravidão, negritude, reparações, apartheid, identidade nacional, indigenismo etc. "Sua ausência daquilo que é considerado filosofia séria é um reflexo não de sua falta de seriedade, mas da cor da vasta maioria dos filósofos acadêmicos ocidentais (e, talvez, da falta de seriedade deles)" (Mills, 1997 apud CARNEIRO, S., 2005, p. 49). Mills também salienta que, em vez de um contrato social ideal, como conhecemos em Hobbes, Locke e Rousseau, construído por meio de metáforas, o contrato racial é historicamente datável e localizável nos eventos históricos.

A supremacia branca foi constituída por múltiplos elementos heterogêneos, em rede, com a proliferação de discursos associados à racialidade: bulas papais, discussões sobre colonialismo, decisões jurídicas, debates sobre a humanidade dos não-brancos. Sueli Carneiro mostra que as representações sobre o negro que passaram a circular neste período conformaram a justificativa para ser possível a existência de senhores e escravos.

O saber produzido sobre negras e negros se constituiu, até agora, desconectado do negro e de suas reivindicações. Sobre nós, sem nós. E quando parece que este cenário está sendo alterado, mais uma publicação sobre negros é celebrada com pouquíssimos dos autores negros. No período em que o contrato social foi firmado, áreas de conhecimento para "conhecer o outro" foram criadas. Negros como objetos de estudo, título, reconhecimento, poder (CARNEIRO, S., 2005, p. 53). Luiz Gama, Guerreiro Ramos e Abdias do Nascimento, segundo Sueli Carneiro, que nunca tiveram visibilidade ou reconhecimento no campo dos estudos raciais.

\footnotetext{
"A nova geração de intelectuais negros que romperam as barreiras que vêm

historicamente limitando, impedindo, cerceando o acesso dos negros às instâncias superiores de conhecimento, aportam, por força dessas mesmas condições, novas questões que essa tradição acadêmica não chegou a enfrentar em toda a sua extensão. Inserem-na não apenas como campo de saber, mas também como espaço de reprodução e perpetuação de poderes que se situam para além da vida acadêmica, como expressão do dualismo racial em que poderiam ser redutíveis às relações raciais no Brasil" (CARNEIRO, S., 2005, p. 56).
} 
Na passagem da escravidão para a libertação, segundo Sueli Carneiro, o negro sai da história para entrar nas Ciências, de objeto de trabalho, torna-se objeto de pesquisa. "A invisibilização da presença negra na cena brasileira, que gradualmente vai se processando, contrasta com a vasta produção acadêmica que irá se desenvolvendo em torno dessa nova condição de objeto de estudo" (CARNEIRO, S., 2005, p. 57). Um epistemicídio que constrói, paradoxalmente, um campo de saber.

\title{
Biopoder, genocídio, necropolítica: sua expressão como epistemicídio
}

\author{
Quem vai pagar a conta? \\ Quem vai contar os corpos? \\ Quem vai catar os cacos dos corações? \\ Quem vai apagar as recordações? \\ Quem vai secar cada gota? \\ De suor e sangue \\ Cada gota de suor e sangue \\ De suor e sangue
}

(Trecho da música Cabô, de Luedji Luna)

Biopoder diz respeito ao poder sobre a vida e a morte. Entre o final do século XVIII e início do século XIX, segundo Foucault, com o objetivo de governar não apenas indivíduos, mas seu conjunto, em população, emerge a biopolítica, que faz a gestão da saúde, da higiene, da alimentação, da sexualidade, da natalidade (REVEL, 2005, p. 26). Enquanto a disciplina, nos termos foucaultianos, se dá nos corpos e se aplica a indivíduos, a biopolítica se aplica à população a fim de governar a vida. Tal biopolítica, convertida em biopoder, passa a fazer viver e a deixar morrer. É aí que, segundo o autor, o racismo se insere como mecanismo fundamental de poder. Mesmo que o racismo existisse anteriormente, é nesse momento que as tecnologias de poder disciplinar - aplicadas a indivíduos - se transformam para a utilização do racismo pelo Estado a toda uma população. É colocado o corte entre quem deve viver e quem deve morrer.

Talvez este tenha sido o tópico mais difícil de escrever em todo o trabalho. Ler teoria, como já deve ter sido possível perceber neste ponto do texto é, para mim, possibilidade de interpretar o concreto, a realidade, o cotidiano. A cada parágrafo sobre fazer ou deixar viver $\mathrm{X}$ matar ou deixar morrer, visualizei cenas que me provocam profunda dor. 
Recentemente, acompanhei uma amiga em uma cirurgia no Hospital Sírio Libanês, na região central de São Paulo. Considerado um dos melhores centros de tratamento, a instituição privada é também um hotel de luxo, em que o quarto onde ela foi cuidada tinha cerca de 80 metros quadrados: sala, banheiro para visitantes, banheiro da paciente, dois frigobares e um imenso ambiente onde ficava a maca. Para acompanhantes, restaurantes, doceria e café, de redes consideradas de muita qualidade; piano no saguão, com uma pianista contratada, provavelmente, para deixar o ambiente mais leve. Além de serem vendidas as melhores possibilidades de diagnóstico e tratamento. Tudo para que o Ser possa viver.

Aos doze anos de idade, em 1996, cheguei ao Hospital Municipal do Mandaqui, na Zona Norte de São Paulo, acompanhada de minha mãe e meu tio materno, depois de receber a notícia de que meu pai dera um tiro na própria cabeça. $\mathrm{Na}$ espera, no estacionamento da emergência, que me chamava a atenção por ser agradável pela quantidade de árvores, estávamos nós, outros tios e tias, familiares de outras pessoas baleadas e acidentadas. Quando pude entrar na sala onde meu pai estava, dentre outras muitas macas, uma delas vigiada por dois policiais militares fardados, vi primeiro o lençol sujo de sangue.

Depois, seu rosto parcialmente desfigurado, com sangue pisado e inchaço onde antes estava seu olho direito. Ele estava consciente. Percebi que sentia vergonha por me ver ali. "Por que você fez isso?" Silêncio em resposta. Quem explicaria uma tentativa de suicídio à própria filha? Ou, de acordo com sua irmã mais próxima, como alguém sairia do jogo do bicho sem ser assassinado? Essa tia nunca acreditou na versão do suicídio, sempre disse que foi morto por uma das bancas que controlavam o jogo ilegal na cidade ou pela própria polícia. "Eu te amo, Bi", foi a única coisa que me disse quando peguei sua mão, antes de sair daquele lugar cheio de gente e luz. Depois de quinze dias internado e uma infecção hospitalar, morreu por traumatismo craniano. Meu pai, Feliciano Mamede de Brito, Félix, o Outro.

Em dezembro de 2007, meu tio materno, que exercera para mim a função paterna, com quem vivi até os 19 anos de idade, foi internado com dificuldade de respirar. Depois de mais de uma década de alcoolismo, e uma outra década sem beber, os vizinhos davam notícias de que ele estava bebendo às vezes. Muito magro, sem se dedicar a qualquer atividade que trouxesse prazer ou dinheiro, aos 54 anos de idade estava com pneumonia, que só descobrimos depois de muita insistência para ir ao hospital. Hospital Presidente, também na Zona Norte de São Paulo, privado, que atende pessoas de classe média baixa 
que pagam os planos de saúde mais baratos. Em poucos dias foi para a UTI e morreu por infecção hospitalar. Meu tio, Haroldo Pereira Santana, chamado pelos amigos de Barba, também o Outro.

Nenhuma dessas mortes foi olhada pela minha família, ou por mim mesma, como ação deliberada do Estado do matar ou deixar morrer, é evidente. Meu pai nunca deveria ter se envolvido com o jogo do bicho, meu tio deveria ter cuidado da própria saúde, era o discurso. Assim como Paulo Vitor, primo da minha mãe, com idade muito próxima à minha, que deveria ter estudado, trabalhado e nunca ter se metido com o tráfico de drogas. Aos 22 anos de idade, recebeu dois tiros nas costas em uma viela no Jardim Brasil, também Zona Norte de São Paulo. Disseram, no enterro que foi a polícia, mas nunca tivemos confirmação e nem teremos. Meu primo, Paulo Vitor Cavalcanti Santana, o Outro.

Como então, escrever com distanciamento?

Recorro a Grada Kilomba, que demanda uma epistemologia que inclua a pessoa e o sujeito como parte do discurso acadêmico. "Meus escritos podem ser incorporados de emoção e de subjetividade, pois, contrariando o academicismo tradicional, as/os intelectuais negras/os se nomeiam, bem como seus locais de fala e escrita, criando um novo discurso com uma nova linguagem" (KILOMBA, 2019, p. 58). A transgressão da linguagem do academicismo clássico, empregando um discurso tanto político quanto pessoal é poético, deveria ser, para Grada Kilomba, a preocupação primordial da descolonização do conhecimento acadêmico.

E um dia depois da escrita de minha dor, volto a bell hooks, buscando uma referência sobre memória, e me deparo com algo que havia escapado, e que agora faz tanto sentido:

Gloria Watkins [nome civil de bell hooks]: Por que você começou pela importância de se lembrar da dor?

bell hooks [pseudônimo de Gloria Watkins]: Porque às vezes eu fico assombrada, como quando acho que algo é aterrorizante, por exemplo, ao ver que muitas das pessoas que escrevem sobre dominação e opressão estão distanciadas da dor, da experiência de ser ferido, da feiura. Na maioria das vezes, é como se o que estivesse em jogo fosse apenas um assunto - um 'discurso'. A pessoa não acredita de fato que 'o que eu digo aqui, essa teoria que estou apresentando, pode ajudar a transformar a dor que eu sinto ou que outras pessoas sentem'. Digo que é importante se lembrar da dor porque acredito que a verdadeira resistência começa pelo enfrentamento da dor, seja da própria dor ou da dor de outra pessoa, e de querer fazer algo para transformá-la. E é essa dor que deixa tantas marcas na vida cotidiana. A dor como catalisadora de transformações, de atitudes em busca de transformação. Às vezes, trabalhando no ambiente 
acadêmico, percebo que o fato de colegas meus não entenderem essa dor é o que cria uma sensação tão profunda de isolamento. Acho que é por isso que, em todos os lugares pelos quais passo, meus verdadeiros camaradas muitas vezes são trabalhadores não acadêmicos - que conhecem essa dor, que estão dispostos a falar dessa dor. É isso que nos conecta - a consciência de que conhecemos essa dor, de que já a vivenciamos ou viremos a enfrentá-las novamente. Isso faz parte da experiência negra na qual Toni Morrison se baseou para escrever Amada (hooks, 2019, p. 401402).

Em um ensaio, a nobel de literatura Toni Morrison contou de seu processo para a escrita de Amada. Na pesquisa para um livro em que trabalhava como editora, encontrou um recorte de jornal de 12 de fevereiro de 1856, cuja manchete "Uma visita à mãe escrava que matou a filha" a capturou. Da situação muito complexa, chamou a atenção de Morrison, especialmente, a incapacidade da sogra de condenar o infanticídio, e a tranquilidade da mulher que cometeu o assassinato. Concluiu que a única pessoa com direito inquestionável de julgar era a criança morta. E, tendo como elemento central essa criança, o romance é desenrolado. "A ficção narrativa proporciona uma selva controlada, uma oportunidade de ser e se tornar o Outro. O estrangeiro. Com empatia, clareza e o risco de uma autoinvestigação" (MORRISON, 2019, p. 121). Assim como faz bell hooks, tento compreender, nesta tese se a não-ficção narrativa de uma tese poderia também oferecer essa oportunidade.

O racismo, segundo Foucault, é condição indispensável para se poder eliminar vidas, como nas situações narradas acima, mas também em muitas outras. "É nessa perspectiva que inscrevemos a negritude sob o signo da morte, a partir da análise das distinções que se apresentam no processo nascer-adoecer-morrer ou simplesmente no processo viver-morrer de negros e brancos na sociedade brasileira, em que se aliam predisposições genéticas com a produção de condições de vida diferenciadas, que se baseia, como afirma Foucault, em

(...) 'estabelecer uma censura que será do tipo biológico no interior de um domínio considerado como sendo precisamente um domínio biológico' (Foucault, 2002, p. 304-305). Essa é para Foucault a primeira função do racismo. A segunda consiste em que a eliminação dos inferiores, impuros, anormais ou diferentes torna-se condição para a assepsia social: "é o que vai deixar a vida em geral mais sadia; mais sadia e mais pura" (Foucault, 2002, p. 305) (CARNEIRO, S., 2005, p. 74).

Vale reforçar a distinção entre as tecnologias de poder instituídas pelos dispositivos disciplinares - do indivíduo, de adestramento do corpo, sobretudo para o trabalho - das 
novas tecnologias de poder instituídas pelo biopoder, de fazer viver, deixar morrer. No adestramento do corpo, o dispositivo de racialidade definiu disciplinar o corpo branco destinado para o trabalho livre, embora também dissesse respeito a alguns corpos negros que eventualmente escapassem das técnicas do biopoder.

É a composição do dispositivo de racialidade com o biopoder que se torna pois como propomos nesta tese mecanismo de produção de dupla conseqüência: promoção do vitalismo dos brancos e multicídios de negros na esfera do biopoder. Sob a égide do dispositivo de racialidade afigura-se a inclusão prioritária e majoritária nas esferas de reprodução da vida dos racialmente eleitos, e, ao mesmo tempo, a inclusão subordinada e minoritária de negros, eventualmente sobreviventes das tecnologias do biopoder (CARNEIRO, S., 2005, p. 94).

Em sua tese, Sueli Carneiro propõe que as sociedades multirraciais resultantes da colonização, como a brasileira, engendraram o dispositivo de racialidade como instrumento disciplinar das relações raciais. Ajusta-se a população pela política imigratória, tanto com o objetivo de embranquecimento estético e eugênico como em uma estratégia de modernização econômica que passa por privilegiar o grupo racial considerado adequado a ele, o Ser. E são definidos, dentre os corpos do Outro, os que poderiam suportar o desenvolvimento capitalista, como estoques raciais de mão-de-obra.

Em nossa elaboração, entendemos que onde não há para o dispositivo de racialidade interesse de disciplinar, subordinar ou eleger o segmento subordinado da relação de poder construída pela racialidade, passa a atuar o biopoder como estratégia de eliminação do Outro indesejável. O biopoder aciona o dispositivo de racialidade para determinar quem deve morrer e quem deve viver (CARNEIRO, S., 2005, p. 76).

Em denúncia protocolada à Comissão Interamericana de Direitos Humanos pela Coalizão Negra por Direitos, em 2 de janeiro de 2020, a advogada Sheila Carvalho sistematizou dados atuais da eliminação do Outro indesejável:

O risco de ser vítima de homicídio doloso não se dá de modo aleatório e indiscriminado. Existe um perfil explícito dos principais alvos: jovens (59,1\%), negros (75,5\%), e homens (91,8\%). Em 2016, o Senado Federal reconheceu que a "cada 23 minutos ocorre a morte de um jovem negro no Brasil" e que "este processo de genocídio está umbilicalmente marcado pelo racismo institucional". Assim um grande e exaustivo trabalho, a CPI do Senado concluiu que "o Estado brasileiro, direta ou indiretamente, provoca o genocídio da população jovem e negra".

O Atlas da Violência 2019, produzido pelo Ipea e pelo Fórum Brasileiro de Segurança Pública (FBSP), apresenta informações perturbadoras. Na 
análise das mortes de 2017 no Brasil,verificou-se que a taxa de homicídios entre jovens de 15 a 29 anos é de 69,9 mortes a cada 100 mil habitantes; esse dado piora quando é adicionado o recorte de gênero: homens jovens no Brasil tem uma taxa de 130,4 homicídios a cada 100 mil habitantes.

Em 2017, o Brasil alcançou a marca histórica de 65.602 homicídios. Isso equivale a uma taxa de 31,6 mortes para cada 100 mil habitantes, correspondente a 30 vezes a taxa da Europa. Nos últimos dez anos, 618.858 pessoas perderam suas vidas devido à violência intencional no Brasil. E os alarmantes dados sobre o juvenicídio apontam uma situação ainda mais grave e que se acentuou no último ano: os homicídios respondem por 59,1\% da causa de óbito de homens entre 15 a 19 anos.

A adição da questão racial escancara ainda mais uma desigualdade baseada em cor. Os dados demonstram que, entre 2016 e 2017, a taxa de homicídios de indivíduos não negros diminuiu 0,8\%, ao passo que a taxa de vitimização da população negra aumentou 9,1\% no mesmo período. Assim, em 2017, enquanto se observou uma taxa de homicídio para a população negra de 43,1, o mesmo indicador para o resto da população foi de 16,19 o que implica dizer que $75,5 \%$ das pessoas que são assassinadas a cada ano no país são pretas ou pardas. O Índice de Vulnerabilidade Juvenil à Violência, ano base 2015, demonstrou que o risco de um jovem negro ser vítima de homicídio no Brasil é 2,7 vezes maior que o de um jovem branco (COALIZÃO NEGRA POR DIREITOS, 2020).

O Genocídio do negro brasileiro: processo de um racismo mascarado, obra clássica de Abdias Nascimento (2016) tem dois verbetes em destaque no início do livro, como se fossem epígrafes:

GENOCÍDIO - geno-cídio

O uso de medidas deliberadas e sistemáticas (como morte, injúria corporal e mental, impossíveis condições de vida, prevenção de nascimentos), calculadas para o extermínio de um grupo racial, político ou cultural ou para destruir a língua, a religião ou a cultura de um grupo"

Webster's Third New International Dictionary of the English LAnguage, Springfield: G\&C MErriam, 1967

GENOCÍDIO - geno-cídio

Genocídio s.m. (neol). Recusa do direito de existência a grupos humanos inteiros, pela exterminação de seus indivíduos, desintegração de suas instituições políticas, sociais, culturais, linguísticas e de seus sentimentos nacionais e religiosos. Ex: perseguição hitlerista aos judeus, segregação racial etc.

Dicionário escolar do Professor, organizado por Francisco da Silveira Bueno. Brasília: Ministério da Educação e Cultura, 1963, p. 580

O ensaio foi escrito para ser apresentado por Abdias no Segundo Festival Mundial de Artes e Culturas Negras e Africanas, realizado em 1977, na Nigéria, mas não pode ser apresentado. O professor Pio Zirimu, então diretor do Colóquio, que havia encomendado o 
texto a Abdias, escreveu uma carta lamentando que o establishment, em suas palavras, havia recusado o texto.

Abdias havia vivido na Nigéria, por um ano, entre 1975 e 1976, em um intervalo entre os 12 anos que esteve exilado nos Estados Unidos. Foi ao Festival, apesar da conferência ter sido rejeitada, a convite da Unesco. O veto a seu nome foi um pedido do governo militar brasileiro ao país com que estava estabelecendo relações comerciais. O Departamento de Línguas e Literaturas Africanas da Universidade de Ifé mimeografou o texto e o distribuiu a todos os participantes do Colóquio.

\begin{abstract}
Não posso e não me interessa transcender a mim mesmo, como habitualmente os cientistas sociais declaram supostamente fazer em relação às suas investigações. Quanto a mim, considero-me parte da matéria investigada. Somente da minha própria experiência e situação no grupo étnico-cultural a que pertenço, interagindo no contexto global da sociedade brasileira, é que posso surpreender a realidade que condiciona o meu ser e o define. Situação que me envolve qual um cinturão histórico de onde não posso escapar conscientemente sem praticar a mentira, a traição, ou a distorção da minha personalidade (NASCIMENTO, A., 2016, p. 47).
\end{abstract}

Os temas desenvolvidos no ensaio, que posteriormente se tornam títulos de capítulos do livro, elencam as peças que compõem o genocídio de negras e negros no Brasil: Escravidão: o mito do senhor benevolente; Exploração sexual da mulher africana; $\mathrm{O}$ mito do "africano livre"; O branqueamento da raça: uma estratégia de genocídio; Discussão sobre raça: proibida; Discriminação: realidade racial; Imagem racial internacional; $\mathrm{O}$ embranquecimento cultural: outra estratégia de genocídio; A perseguida persistência da cultura africana no Brasil; Sincretismo ou folclorização; A bastardização da cultura afrobrasileira; A estética da brancura dos artistas negros; Uma reação contra o embranquecimento: o Teatro Experimental do Negro.

Uma das faces do genocídio negro, conforme se pode abstrair pelos temas elencados por Abdias do Nascimento diz respeito à cultura, na terminologia do programa de pósgraduação em que esta tese é apresentada, à informação e ao conhecimento. A este respeito, Sueli Carneiro toma uma noção emprestada de Boaventura de Sousa Santos e a aprimora, a de epistemicídio.

Para Boaventura, o epistemicídio se constituiu em um dos instrumentos mais eficazes e duradouros da dominação racial, por negar a legitimidade das formas de conhecimento dos dominados, do conhecimento por eles produzido e, consequentemente, 
de seus membros enquanto sujeitos de conhecimento. O único saber reconhecido é o eurocêntrico e hegemônico.

Segundo formula Sueli Carneiro, o epistemicídio vai além da anulação e desqualificação do conhecimento dos povos subjugados. Trata-se de um processo persistente de produção da indigência cultural, pela negação ao acesso à educação de qualidade; pela produção da inferiorização intelectual; pelos diferentes mecanismos de deslegitimação do negro como portador e produtor de conhecimento e de rebaixamento da capacidade cognitiva pela carência material e/ou pelo comprometimento da auto-estima pelos processos de discriminação correntes no processo educativo.

É uma forma de seqüestro da razão em duplo sentido: pela negação da racionalidade do Outro ou pela assimilação cultural que em outros casos lhe é imposta.

Sendo, pois, um processo persistente de produção da inferioridade intelectual ou da negação da possibilidade de realizar as capacidades intelectuais, o epistemicídio, nas suas vinculações com as racialidades, realiza, sobre seres humanos instituídos como diferentes e inferiores, uma tecnologia que integra o dispositivo de racialidade/biopoder, e que tem por característica específica compartilhar características tanto do dispositivo quanto do biopoder, a saber, disciplinar/ normalizar e matar ou anular. É um elo de ligação que não mais se destina ao corpo individual e coletivo, mas ao controle de mentes e corações.

A escola, para Sueli Carneiro, é fonte de múltiplos aniquilamentos ou subordinação dos Outros, indesejados. Além do rebaixamento da auto-estima, que compromete a capacidade cognitiva e a confiança intelectual, há a negação a negras e negros da condição de sujeitos de conhecimento, nos instrumentos pedagógicos ou nas relações sociais no cotidiano escolar, pela deslegitimação dos saberes dos negros sobre si mesmos e sobre o mundo, pela desvalorização, negação e ocultamento das contribuições africanas e afrobrasileiras ao patrimônio cultural da humanidade.

O epistemicídio ainda é um tema distante da ciência da informação. Um resumo de artigo apresentado em 2019 por três estudantes de graduação, Jéssica Paola Macedo Müller, Francine Conde, Amanda Dall'Agnol Barbosa, em co-autoria com o professor Rodrigo Silva Caxias de Sousa, todos da Universidade Federal do Rio Grande do Sul, busca ocorrências de estudos científicos sobre o epistemicídio na área da ciência da Informação.

Buscaram na base de dados da Capes, as expressões "Epistemicide" e "Information Science". Encontraram um único artigo que correspondia a ambos os termos: "The mechanics of democracy promotion tools: bridging the knowledge-to-practice gap”, escrito 
por Sead Alihodžić, program officer de um organização sueca chamada International Institute for Democracy and Electoral Assistance. Imagino que tenha sido um erro de indexação não percebido pelas pesquisadoras. Sob as palavras-chave "Aid - Aid effectiveness, Development policies, Capacity development; Methods; Technology - ICT; Civil society - Participation; Governance and public policy", o texto trata dos usos de ferramentas digitais para a promoção da democracia, sem uma única menção ao termo epistemicídio, em português ou inglês. Na busca realizada para o termo "epistemicide", encontraram 409 resultados, de outras áreas do conhecimento (MÜLLER et al, 2019).

Independentemente do uso do termo epistemicídio, o debate racial como um todo não tem recebido atenção na ciência da informação. Em 2018, os pesquisadores Luciana Pereira Vicente Ortolan, Marcio Ferreira da Silva, Roberta Caroline Vesu Alves e Daniel Martínez Ávila buscaram artigos na Base de Dados em Ciência da Informação (BRAPCI), com o termo "negro", depois de não obterem resultados para "afrodescendente" e "mulato". Encontraram 36 resultados, conforme se pode ver no quadro abaixo, de publicações feitas entre 1979 e 2014.

Quadro 4: Quantidade de publicações por autor sobre a temática relacionada ao negro no Brasil em Ciência da Informação

\begin{tabular}{|l|c|l|}
\hline \multicolumn{1}{|c|}{ AUTOR } & QUANTIDADE & $\begin{array}{l}\text { LOCALIDADES DA ATUAÇÃO PROFISSIONAL OU } \\
\text { FORMAÇÃO DOS AUTORES }\end{array}$ \\
\hline $\begin{array}{l}\text { Mirian de Albuquerque } \\
\text { Aquino }\end{array}$ & 18 & $\begin{array}{l}\text { Universidade Federal da Paraíba (João Pessoa - PB). Região } \\
\text { Nordeste. }\end{array}$ \\
\hline $\begin{array}{l}\text { Jobson Francisco da Silva } \\
\text { Júnior }\end{array}$ & 4 & $\begin{array}{l}\text { Universidade Federal do Estado do Rio de Janeiro (Rio de } \\
\text { Janeiro - RJ). Região Sudeste. }\end{array}$ \\
\hline $\begin{array}{l}\text { Leyde Klebia Rodrigues da } \\
\text { Silva }\end{array}$ & 4 & $\begin{array}{l}\text { Universidade Federal do Estado do Rio de Janeiro (Rio de } \\
\text { Janeiro - RJ). Região Sudeste. }\end{array}$ \\
\hline Vanessa Alves Santana & 2 & $\begin{array}{l}\text { Universidade Federal da Paraíba (João Pessoa - PB). Região } \\
\text { Nordeste. }\end{array}$ \\
\hline Delton Aparecido Felipe & 2 & $\begin{array}{l}\text { Universidade Estadual de Maringá (Maringá - PR). Região } \\
\text { Sul. }\end{array}$ \\
\hline $\begin{array}{l}\text { Henry Pôncio Cruz de } \\
\text { Oliveira }\end{array}$ & 2 & $\begin{array}{l}\text { Universidade Federal da Paraíba (João Pessoa - PB). Região } \\
\text { Nordeste. }\end{array}$ \\
\hline Ronhely Pereira Severo & $\begin{array}{l}\text { Escola Municipal Zumbi dos Palmares- Mangabeira (João } \\
\text { Pessoa - PB). Região Nordeste. }\end{array}$ \\
\hline $\begin{array}{l}\text { Sérgio Rodrigues de } \\
\text { Santana }\end{array}$ & 2 & $\begin{array}{l}\text { Universidade Federal da Paraíba (João Pessoa - PB). Região } \\
\text { Nordeste. }\end{array}$ \\
\hline Teresa Kazuko Teruya & $\begin{array}{l}\text { Universidade Estadual de Maringá - (Maringá - PR). } \\
\text { Região Sul. }\end{array}$ \\
\hline
\end{tabular}

Fonte: ORTOLAN et al, 2018

Na conclusão do artigo, os autores pontuam:

Atualmente, apesar da conquista de vários direitos, e políticas públicas e do crescimento de publicações nos últimos anos, ainda nos deparamos fortemente com o preconceito racial em diversas áreas, pois o negro é 
encarado como inferior ao branco em muitas situações. Nos últimos anos, o panorama apresentado foi mudando gradualmente, como percebemos, pela maior quantidade de negros em universidades cursando nível superior, apresentando os telejornais, atuando em algumas propagandas, e também publicações científicas que os mostram em estudos científicos (ORTOLAN et al, 2018).

Chego à ciência da informação no doutorado, depois de um mestrado em educação, uma graduação em jornalismo e outra inconclusa em ciências sociais. Tenho muitas defasagens na compreensão do campo, especialmente no que tange à área de organização da informação e do conhecimento. Mas me chamou muito a atenção o alerta que uma colega bibliotecária me fez a respeito da CDD - Classificação Decimal de Dewey, sistema de classificação de documentos, utilizado mundialmente para organizar livros.

De antemão, me desculpo por reproduzir toda a classe 200 - Religião. Mas é exemplar:

200.1 - Valores, princípios

200.3 - Dicionários e enciclopédias de religiões

200.19 - Psicologia religiosa

200.71 - Educação

200.9 - História - Atlas Bíblico

210 - Filosofia e teoria da religião

211 - Conceitos de Deus / Fé ( classificar aqui trabalhos sobre Deus e a Fé)

(Panteísmo, Teísmo, Racionalismo, Deísmo, Humanismo, Agnosticismo)

211.8 - Ateísmo

212 - Existência, conhecimento e atributos de Deus

213 - Criação e evolução do homem

215 - Ciência e religião

218 - Gênero humano (incluindo imortalidade )

220 - Bíblia

220.7 - Estudo da Bíblia

220.9 - Bíblia - Atlas histórico / Descrição e geografia bíblicas

220.93 - Arqueologia bíblica

221 - Antigo Testamento

222 - Livros históricos do AT ( Pentateuco, Gênesis, Êxodo, Levítico, Números, Deuteronômio, Josué, Juízes, Rute, Samuel, Reis,

Crônicas, Esdras, Neemias, Ester)

223 - Livros poéticos do AT (Jó, Eclesiastes)

223.2 - Salmos

223.7 - Provérbios

223.9 - Cantos de Salomão (Cântico dos Cânticos)

224 - Livros proféticos do AT (Isaías, Jeremias, Lamentações, Ezequiel, Daniel, Oséias, Joel, Amós, Profetas Menores)

225 - Novo Testamento 
226 - Evangelhos e Atos dos Apóstolos

226.2 - Evangelho de Mateus

226.3 - de Marcos

226.4 - de Lucas

226.5 - de João

226.6 - Atos dos Apóstolos

226.7 - Milagres

226.8 - Parábolas

226.9 - Sermão da Montanha

226.96 - Pai Nosso

227 - Epístolas

227.1 - Aos Romanos

227.2 -Aos Coríntios I

227.3 - Aos Coríntios II

227.4 - Aos Gálatas

227.5 - Aos Efésios

227.6 - Aos Filipenses

227.7 - Aos Colossenses

227.8 - Outras epístolas de São Paulo

227.81 - Aos Tessalonicenses I

227.82 - Aos Tessalonicenses II

227.83 - A Timóteo I

227.84 - A Timóteo II

227.85 - A Tito

227.86 - A Filemon

227.87 -Aos Hebreus

227.9 - Epístolas católicas

227.91 - Tiago

227.92 - Pedro I

227.93 - Pedro II

227.94 - João I

227.95 - João II

227.96 - João III

227.97 - Judas

228 - Apocalipse

229 - Trabalhos Apócrifos, Pseudoepígrafos, Intertestamental

230 - Cristianismo / Teologia Cristã / Mitologia cristã

230.007 - Educação, pesquisa

231 - Deus - Modos do conhecimento de Deus como Fé / Razão /

Tradição

231.1 - Santíssima Trindade

232 - Jesus Cristo, sua vida e sua família - Cristologia

232.1 - Encarnação

232.3 - Cristo como Redentor

232.4 - Sacrifício de Cristo

232.5 - Ressurreição

232.8 - Divindade e humanidade

232.9 - Família e vida de Jesus

232.901 - Vida de Jesus

232.903 - Caráter e personalidade de Jesus

232.91 - Maria como Mãe de Jesus (Mariologia)

232.911 - Imaculada Conceição

232.912 - Anunciação

232.913 - Virgindade 
232.914 - Assunção

232.915 - Santidade e virtudes - Milagres de Nossa Senhora

232.92 - Nascimento e infância de Jesus

232.93 - Família de Maria

232.932 - José

232.94 - João Batista

232.95 - Vida pública

232.955 - Milagres de Jesus

232.96 - Paixão e Morte

232.964 - Sepultamento / Santo Sudário

232.97 - Ressurreição

233 - Gênero Humano (Criação , natureza divina, tentação, liberdade de escolha e pecado )

234 - Salvação e graça / Santificação

234.1 - Tipos e significados da graça

234.16 - Pelos sacramentos

234.2 - Fé e esperança

234.3 - Redenção

234.4 - Regeneração

234.5 - Arrependimento e perdão

234.6 - Obediência

234.7 - Absolvição

234.8 - Santificação e santidade

234.9 - Predestinação e livre arbítrio

235 - Vida espiritual

235.2 - Santos

235.3 - Anjos

235.4 - Demônio

236 - Escatologia ( Morte, vida eterna, céu, purgatório, inferno)

238 - Credos, confissão das faltas / Promessas

239 - Polêmicas (Argumentações sobre dogmas cristãos: virgindade, SS. Trindade, etc.)

240 - Moral cristã e teologia da devoção (Consciência, virtudes, códigos de conduta, vícios, Pecado)

241 - Teologia moral

241.1 - Consciência

241.2 - Leis e bases da moralidade

241.3 - Pecado e vícios

241.4 - Virtudes

241.5 - Códigos de conduta ( Dez Mandamentos, Sermão da Montanha )

241.6 - Questões morais específicas / Ética, moral, sexualidade religiosas (relacionamento conjugal, controle de natalidade, namoro, noivado casamento, família) - ver também 392.4 e 392.5

242 - Orações / Preces / Literatura devota / Textos de meditação e contemplação )

242.2 - Orações de uso diário

242.3 - Orações de uso no ano litúrgico / festas religiosas / Símbolos

242.332 - Advento

242.335 - Natal

242.34 - Quaresma

232.35 - Semana Santa

242.36 - Páscoa / Ascensão

242.37 - Outras festas / Dias de Santos 
242.38 - Pentecostes

242.5 - Preces e meditações baseadas na Bíblia

243 - Escritos evangélicos para pessoas e para famílias

246 - Uso da arte no cristianismo

246.5 - Ícones, símbolos, incenso, velas, cruzes, crucifixos, cores e luzes

246.7 - Dramatizações

246.75 - Músicas

247 - Mobiliário religioso

248 - Cristãos: experiência, prática, vida, misticismo, conversão, cultos e testemunhos

248.2 - Experiências religiosas (Misticismo, conversão)

248.3 - Cultos, preces, meditações e contemplações

Prática religiosa

Amor a Deus

248.4 - Vida e práticas cristãs / Reflexões / Mensagens /

Espiritualidade Guias para a vida familiar cristã

248.5 - Testemunhos

248.8 - Guias de vida para cristãos por classes específicas :

248.82 - Crianças

248.83 - Jovens

248.84 - Adultos

248.842 - Homens

248.8421 - Pais

248.843 - Mulheres

248.8431 - Mães

248.844 - Casais

248.846 - Pessoas separadas, divorciadas

248.85 - Velhos

248.86 - Doentes, deficientes

248.88 - Classes ocupacionais

248.8942 - Padres / Vocações

248.8943 - Freiras / Vocações

249 - Observância católica na vida familiar: preces, ritos, cerimônias familiares

250 - Ordens religiosas e igrejas locais

251 - Práticas

252 - Sermões

253 - Trabalho pastoral

253.78 - Pelo rádio e televisão

254 - Administração da paróquia

255 - Congregações religiosas ( $\mathrm{p} /$ homens e $\mathrm{p} /$ mulheres)

258 - Assistência religiosa / Pastoral

259 - Campanhas/ Cuidados /Campanha da Fraternidade

260 - Teologia social e eclesiástica / Organização do Cristianismo

261 - Papel da Igreja na sociedade (Igreja x Outras religiões / Igreja x

Política / Igreja x Problemas sócio- econômicos como fome,

crimes, ecologia, racismo, sexo, guerras, etc.

261.7 - Cristianismo e política

Cristianismo e direitos civis

261.72 - Liberdade religiosa

261.73 - Teocracia (Supremacia da Igreja sobre o governo civil)

262 - A Igreja

262.006 - Administração, organização 
262.1 - Função e autoridade dos chefes da Igreja

262.12 - Bispos, arcebispos, etc. Conferências de bispos

262.13 - Papa (infalibilidade, mandato)

262.135 - Colégio de cardeais

262.14 - Clero local / Paróquias

262.5 - Concílios

262.7 - Relação de Deus com a Igreja / Comunicação de Santos

262.9 - Normas e leis e disciplina da Igreja

262.91 - Encíclicas, decretos papais

262.92 - Códigos antigos

262.93 - Códigos novos

262.94 - Códigos novos

263 - Observância dos dias e tempos próprios da Igreja / Celebrações

263.3 - Domingo

263.9 - Dias e tempos do ano religioso

263.912 - Advento

263.915 - Natal

263.92 - Quaresma

263.93 - Páscoa e Ascensão

263.94 - Pentecostes

263.97 - Outras festas

263.98 - Dias santos

264 - Cerimônias / Ritos / Liturgia

264.023 - Missais - Textos

264.1 - Preces / Breviários

264.2 - Músicas / Cantos / Hinos

264.3 - Missa / Eucaristia

264.36 - Primeira Eucaristia

265 - Sacramentos

265.1 - Batismo

265.2 - Crisma

265.4 - Ordem

265.5 - Matrimônio / Casamento

265.6 -Penitência / Confissão

265.7 - Eucaristia

265.8 - Extrema unção

265.9 - Outros

265.94 - Exorcismo

266 -Missões / Comunidade Eclesial de Base / Evangelização

267 - Grupos de trabalhos religiosos / Encontro de casais, Jovens, etc.

268 - Ensino Religioso / Catequese ( Pista - Religião - Estudo e ensino)

269 - Conversão / Renovação

270 - História do cristianismo e igreja cristã

270.6 - Reforma protestante com enfoque religioso (ver tb. 940.23)

271 - Ordens e congregações na Hist. da Igreja - Para homens (Católicas)

271.1 - Beneditinos

271.125 - Trapistas

271.2 - Dominicanos

271.3 - Franciscanos

271.36 - Capuchinhos

271.4 - Agostinianos

271.5 - Clérigos regulares

271.53 - Jesuítas

271.6 - Redentoristas e Passionistas

271.7 - Outras ordens católicas 
271.73 - Carmelitas

271.76 - Oblatas

271.77 - Lazaristas

271.79 - Outras ordens católicas para homens (Ordens militares, Cruz de Malta, Templários)

271.8 - Ordens não católicas romanas

271.83 -Anglicanos

271.9 - Congregações e ordens católicas romanas para mulheres

271.98 - Ordens não católicas romanas

272 - Perseguições religiosas na história da Igreja / Inquisição/ Mártires

273 - Controvérsias e heresias na história da Igreja

278 - História da igreja

280 - Denominações e seitas de igrejas cristãs

282 - Igreja Católica Romana

282.03 - Dicionários e enciclopédias da doutrina católica

283 - Igreja Anglicana

284 - Igreja Protestante

285 - Igreja Presbiteriana

286 - Igrejas Batista, Adventista, Discípulo de Cristo, do Sétimo Dia

287 - Igreja Metodista

289 - Outras: Universal, Últimos dias, Nova Jerusalém, Quakers, etc.

290 - Outras religiões

291 - Religiões comparadas (Comparações diversas com política, com sociedade, com problemas sócio- econômicos, etc.)

291.09 - Religiões - História

291.2 - Doutrinas (classificar aqui doutrinas polêmicas como espiritismo, animalismo, deuses do mal, do bem, espíritos, etc.)

291.23 - Escatologia (incluindo morte, fim do mundo, imortalidade, outros mundos, Ressurreição)

291.237 - Reencarnação

292 - Religiões clássicas

292.07 - Religião romana

292.08 - Religião grega

292.13 - Mitologia

293 - Religiões germânicas

294 - Religiões indianas (Budismo, Jainismo, Hinduísmo, Sikhismo)

295 - Zoroastrismo, Mazdaismo, Parseeismo

296 - Judaísmo

297 - Islamismo, Babismo, Crença em Bahai

299 - Outras religiões :Africanas, asiáticas, nativas, etc.

(Umbandismo, macumba, Candomblé, Voodooismo, Ras Tafari, etc.)

Das ocorrências, tantas delas detalhando e detalhando tópicos do cristianismo, há uma classificação para Judaísmo, outra que divide islamismo, babaismo e crença em Bahai. As religiões de matriz africana, todas elas, somadas a religiões asiáticas e "nativas", nem sequer mencionadas, estão na mesma classificação 299, nomeadas como Outras. 
Mas, mais relevante que o tópico acima, de como é organizada a informação, é retomar aquilo que a ciência da informação compreende como produção e circulação da informação. Dentre teorias de diferentes paradigmas epistemológicos da ciência da informação (BARRETO, A., 1994, CRIPPA; RODRIGUES, 2011), parece haver algo em comum: informação compreendida como aquilo que modifica o estado de conhecimento de uma pessoa ou de um grupo.

Diversas autoras e autores já se dedicaram a explicitar as diferenças entre os principais paradigmas deste campo: físico, cognitivo e social (CAPURRO, 2003). Neste trabalho, serão apresentadas brevemente noções da ciência da informação que já partem de elaborações filiadas a um paradigma social, ou seja, que consideram necessidades individuais e de uma comunidade para definir o que é uma informação relevante (CRIPPA; RODRIGUES, 2011).

Aquilo que modifica o estado de conhecimento de uma pessoa ou grupo, a informação, pode ser intangível ou tangível. A informação tangível tem uma materialidade expressa por documentos. Documento, conforme explicou Buckland, é um termo que diz respeito a quaisquer objetos informativos: "livros, conjuntos de dados, manuscritos, gravações musicais, e, sim, uma coleção de aves mortas!" (MOSTAFA, 2011). As cartas, livros, textos impressos ou publicados na internet e redes sociais por mulheres negras são documentos que dão materialidade à informação produzida por estas mulheres.

A informação intangível - os modos de fazer e de ser, como as narrativas orais de mulheres negras, os movimentos de dança, o trançar de cabelo - podem ser compreendidos como performances. Segundo Paul Zumthor, performances podem ser compreendidas como manifestações culturais lúdicas - canto, rito, dança, dentre outras - sempre constitutiva de forma (2014, p. 33). Mais que saber fazer, um saber ser (ZUMTHOR, 2014, p. 34).

Tais performances, segundo a pesquisadora Diana Taylor (2013), têm papel central na conservação da memória e na consolidação de identidades nas mais diversas sociedades, tanto as letradas, quanto as semi letradas e as digitais. As performances funcionariam como atos de transferência vitais, transmitindo o conhecimento, a memória e um sentido de identidade social. Por isso, para a autora, examinar as relações entre a performance incorporadas e reexaminar as performances como produção de conhecimento é um imperativo, por mais difícil que seja fazê-lo em sistemas epistêmicos em que a escrita se tornou avalista da própria existência.

Performance, segundo a autora, também constitui a lente metodológica que permite analisar eventos como performances. Ao aplicá-la, pode-se ampliar o que se entende por 
conhecimento, ao desafiar as epistemologias ocidentais. Ao aplicar tal metodologia, podese ampliar a pesquisa, além dos acontecimentos e casos isolados, para os roteiros que compõem os imaginários individuais e coletivos. "As performances, como a rumba no parque, tornam visíveis esses atores sociais, roteiros, relações de poder que foram deixados de lado e, seguidamente, desapareceram" (TAYLOR, 2013, p. 379).

Performances, gestos, oralidades, movimentos, dança, canto, atos geralmente vistos como conhecimento efêmero, podem então ser compreendidos como repertório. "A tensão entre o que denomino arquivo e repertório tem sido frequentemente construída como existente entre língua escrita e falada. $\mathrm{O}$ arquivo inclui textos escritos, mas não se limita a eles. O repertório contém performances verbais - canções, orações, discursos -, bem como práticas não-verbais. A divisão entre escrito/ oral, em um nível, capta a diferença entre arquivo/ repertório" (TAYLOR, 2013, p. 55). Tradições e memórias-hábito armazenadas no corpo são vivenciadas no presente, como é toda memória, tendo a linguagem verbal como primordial.

Sem utilizar a palavra performance, Allan da Rosa explica como a memória-hábito permite, no presente, vivenciar e atualizar lembranças coletivas:

\begin{abstract}
Quando um repicado no berimbau ou uma melodia de ladainha, um gesto corporal de pernas pro ar ou uma folha, ou ainda o uso de determinada técnica cultural de se construir uma casa (com determinado material que ressoa miticamente), te trazem o primordial e te levam ao antigo, à casa de nascença do toque, a companhia que vem morar em ti e que você exerce refaz o mesmo gesto e cintila a mesma presença de espírito que um ancestral havia iniciado. E que em ti é virgem e é amor renovado, sendo também campo de intensa invenção e de continuidade desejada de um rito, uma linguagem de quem assume responsabilidades e realiza uma compreensão de existência. Consciência de harmonia com as forças grandes, sem intenção apriorística, mas de retorno, de criatividade e de continuidade recíprocas. Espiral que também gira para trás e para fora do tempo social. (ROSA, 2019, p. 43).
\end{abstract}

Os estudos da performance, portanto, permitem assimilar a complexidade do tempo e, portanto, da memória, registrando e analisando informações sobre determinados grupos e comunidades, que os estudos de documentos não permitiriam.

Documento diz respeito tanto à matriz em que a informação é formatada quanto ao suporte que permite a circulação da informação. E como suporte, que fixa o conteúdo, o documento não é inerte, ele age sobre a informação (COUZINET, 2008 apud MARTELETO; COUZINET, 2013). A noção de documento, da forma como tem sido 
ressignificada atualmente, abarca sua divulgação e difusão para a apropriação social da informação.

(....) leva-se em conta a fundamentação das práticas sociais onde se inscrevem os documentos, tanto em suas dimensões mono-técnicas, quanto sócio-econômicas, sócio-políticas e sócio-semióticas, para além da noção de suporte, que lhe é inerente (MARTELETO; COUZINET, 2013).

Segundo as pesquisadoras Johanna Smit, Maria de Fátima Tálamo e Nair Kobashi, a ciência da informação apresenta uma linguagem ainda muito próxima da do senso comum e insuficientemente especializada (SMIT et al, 2004). Produção e circulação de informação, por exemplo, são termos que aparecem com frequência em textos da área sem conceituação. Aqui, utilizaremos as definições propostas por estas pesquisadoras:

* produção: identificação dos códigos explicitadores dos conteúdos registrados sob a forma de informação - resultado das operações sobre os conteúdos registrados que se apresenta sob a forma de conteúdos socializados; articulação entre os dispositivos tecnológicos e a produção da informação;

* circulação da informação: inserção social da informação (SMIT et al, 2004)

Vale lembrar que, no caso da produção da informação por parte de indivíduos e grupos "não especializados" - ou seja, a maioria - esses códigos que seriam “explicitadores" nem sempre aparecem de maneira efetivamente explícita. Como parte do conjunto de códigos que constituem uma determinada cultura, muitas vezes são introjetados pelos indivíduos, constituindo um repertório de conhecimentos tácitos que é acionado pragmaticamente em cada contexto que se faz necessário.

Para Aldo de Albuquerque Barreto, a produção da informação diz respeito à organização e ao controle de estoques de informação, para uso imediato ou futuro, a partir da reunião, seleção, codificação, redução, classificação e armazenamento de informação. A produção da informação seria, portanto, parte significativa daquilo que costuma definir o objeto da ciência da informação: produção, seleção, organização, interpretação, armazenamento, recuperação, disseminação, transformação e uso da informação (GRIFFITH, 1980 apud CAPURRO, 2003).

Segundo Barreto (1994) a circulação de informação, sua distribuição, usos, e podese incluir apropriação, está condicionada por inúmeros fatores. 
Os habitantes destas comunidades sociais diferenciam-se segundo suas condições, como grau de instrução, nível de renda, religião, raça, acesso e interpretação dos códigos formais de conduta moral e ética, acesso à informação, confiança no canal de transferência, codificação e decodificação do código lingüístico comum, entre outros. Estes espaços sociais diferenciados não constituem uma simples justaposição de singularidades, ao contrário são entidades orgânicas com forte sentimento coletivo, um corpo de costumes, tradições, sentimentos e atitudes organizadas. Esta organização concentra um conjunto de saberes, regras, normas, proibições e permissões que são conservadas e transferidas através de canais próprios de comunicação (Maffesoli, 1984 apud BARRETO, 1994)

Democratizar a informação, segundo o autor, não envolveria somente programas para facilitar e aumentar acesso à informação. Os indivíduos precisariam ter também condições de elaborar o insumo recebido, transformando-o em conhecimento, em benefício próprio e da sociedade. “A democratização do acesso à informação também não se limita à reprodução consentida de um estágio de desenvolvimento social homogeneizado por um menor conhecimento comum, que só traz benefício para a eficácia dos estoques e dos produtores de informação" (BARRETO, A., 1994).

O que fica patente é que, para as correntes mais próximas ao paradigma social da informação, ela é concebida como fator de poder e de mudança social. Mas vale ressaltar que a informação - considerada na sua produção, circulação e apropriação - é subordinada aos sistemas culturais e simbólicos que lhes conferem sentido. Desse modo, ela desempenha um papel subordinado em relação aos sistemas de conhecimento, aos esquemas socioculturais de interpretação que dão, à informação, seu status e seu valor (ALMEIDA, 2009b).

Para falar em produção de informação de mulheres negras, portanto, seria necessário identificar os códigos que explicitam conteúdos produzidos por essas mulheres como informação, considerando sua reunião, seleção, classificação e armazenamento. Assim, é necessário identificar: conteúdos registrados (1); que tenham sido socializados (2); a partir de determinados dispositivos tecnológicos (3).

Os processos de organização da informação material costumam ser chamados de documentação. Ela é essencial para facilitar a recuperação e o acesso da informação, ampliando seu caráter público e social, mas não só (FROHMANN, 2013). A categorização, muitas vezes, é o que nomeia a existência de uma informação. "Em termos gerais, não pode haver informação sobre algo de um tipo X se este tipo não existir. E se o tipo não pode existir sem documentação, então a documentação é necessária para que haja informação 
sobre ele" (FROHMANN, 2013). Para explicar esta ideia, Frohmann apresenta um exemplo elaborado por Ian Hacking a partir de Foucault: antes do século XIX, não era possível existir informação sobre homossexuais porque essa categoria não existia. Existia quem praticasse relações sexuais com pessoas do mesmo sexo, o que não havia era um corpo de enunciados, uma categoria "homossexual", que permitisse reunir informação sobre essas pessoas.

Maria Aparecida Moura e Manoel Palhares Moreira explicam a linguagem de documentação, com a característica específica de possuir relações entre os termos que o compõem, chamada tesauro. "Os tesauros constituem uma ferramenta de indexação já consolidada nas atividades de organização da informação empregada por muitos que exercem essas atividades. A flexibilidade de estabelecimento de novas relações entre seus termos, o estabelecimento de hierarquias e referências cruzadas conferem ao instrumento uma multiplicidade de usos, abrangendo os processos desde a indexação até o suporte para a efetiva recuperação dos documentos" (MOURA e MOREIRA, 2006). Tesauros para estudos africanos e afro-brasileiros permitiriam aumentar a visibilidade da temática nos diferentes suportes de informação, além de estimular estudos sobre o tema (LIMA et all, 2014).

Nesse sentido, a invisibilidade da escrita de mulheres negras parece estar mais relacionada com a falta de organização e classificação destes textos e sua disseminação para acesso público, que permita se realizar como informação ao modificar o estado de conhecimento de uma pessoa ou comunidade, do que com a escassez de narrativas escritas produzidas por mulheres negras.

Há quem reivindique, as categorias "literatura afro-brasileira", "literatura negra", "literatura de mulheres negras", da mesma forma que há críticas para essas terminologias, já que poderiam reforçar categorias mais gerais como "literatura", como pertencentes apenas aos grupos dominantes. "Literatura', então, diria respeito à escrita de homens brancos, assim como "literatura feminina", ao mesmo tempo que excluiria mulheres da "literatura", reforçaria que "feminino" diz respeito às mulheres brancas, não às mulheres negras, indígenas, orientais etc. Ao mesmo tempo que a classificação permite criar informação, ela também pode reforçar determinadas generalizações.

Assumir que a materialidade da informação em documentos organizados facilita sua recuperação e acesso, consequentemente sua circulação, reforçando seu caráter público e social (Frohmann, 2013) permite afirmar uma das marcas do dispositivo de racialidade na ciência da informação, e também a ciência da informação como agente do dispositivo de 
racialidade, nas ausências da temática racial e de mulheres negras. Pode-se também afirmar que os estudos de performance poderiam ser úteis à Ciência da Informação ao avançar nos estudos do conhecimento disseminado pelo ser/ fazer, performado na memória-hábito.

Mesmo que na produção, organização e circulação de informação - ou na falta delas caracterizando epistemicídio - seja possível visualizar a configuração do dispositivo de racialidade e o biopoder, é no campo da saúde que a biopolítica se coloca de forma mais contundente. $\mathrm{O}$ campo de intervenção prioritário de biopolítica ao falarmos de mulheres negras é o da saúde. Na determinação do processo saúde-doença-morte, há características distintas para a branquitude e a negritude, cada qual com condicionantes diferenciados quanto ao viver e o morrer.

\begin{abstract}
Foucault, ao inscrever o racismo no âmbito do biopoder, esclarece-nos que este, enquanto tecnologia de poder voltada para a preservação da vida de uns e de abandono de outros à exposição da morte, presta-se à determinação sobre o deixar morrer e o deixar viver. Com a máxima do 'deixar viver, e deixar morrer' como expressão do biopoder, Foucault delimita a função do racismo que integra o biopoder como elemento legitimador do direito de matar, intrínseco ao poder soberano, que no contexto das sociedades disciplinares será exercido pelo Estado, por ação ou omissão (CARNEIRO, S., 2005, p. 77).
\end{abstract}

Além da morbidade, a natalidade é prática central de biopolítica. O Brasil é dos países do mundo com maior índice de cesarianas, a maior parte delas desnecessária do ponto de vista da saúde da mulher ou da criança. Enquanto a OMS estabelece em até 15\% de cesarianas no total de partos de um país, no Brasil esse porcentual é de 57\% (SENADO, 2018). Uma a cada quatro mulheres afirma ter sofrido violência obstétrica, ou seja, recusa de atendimento, procedimentos médicos desnecessários, agressões verbais dentro outras, no pré-natal, no parto ou pós-parto (FPA e Sesc, 2010). Dentre as mulheres que morrem durante o parto, 62,8\% são negras (ALMA PRETA, 2018).

Já na classe média, acompanhada por um homem branco, tive três partos normais chamados "humanizados" com equipe médica particular, no Hospital São Luiz, privado, que atende principalmente a classe média, cuja maternidade tem a menor taxa de infecção hospitalar da cidade e, naquele momento, permitia que equipes externas ao hospital deixassem de seguir o protocolo violento por eles definido, para respeitar o tempo da mulher e da criança, as evidências científicas e recomendações internacionais.

Quando nasceram Lucas, em 2008, e Pedro, em 2010, tive partos naturais muito rápidos e fui protegida por minha família e pela equipe médica particular. A única violência 
sofrida no hospital, que não foi pequena, foi a pressão para que alimentasse Lucas com leite artificial, durante a apojadura - quando, depois do parto, o peito se prepara para a descida do leite que costuma acontecer em três dias. Uma médica chegou a me perguntar se eu sabia o que aconteceria caso meu bebê ficasse desnutrido e, diante de um sim irônico, afirmou que poderia faltar oxigênio no cérebro da criança, que teria sequelas por toda a vida. Apesar do impacto daquelas palavras, eu tinha informação, apoio familiar e profissional suficiente para me proteger daquele ataque. E, no parto seguinte, tudo aconteceu tranquilamente. Apesar de Outra, eu, acompanhada do Ser, deixada viver.

$\mathrm{Na}$ terceira gestação, de Cecília, tive pré-eclampsia, fenômeno gestacional pouco explicado pela medicina, e tem como sintomas a pressão alta e o escape de determinadas proteínas pela urina. O grande risco é tornar-se eclâmpsia e provocar edema cerebral, convulsão e levar a mulher ao coma, o que pode ser fatal para a mulher e a criança. A taxa de pré-eclâmpsia e eclâmpsia entre mulheres negras é quase seis vezes maior do que a de mulheres brancas (MINISTÉRIO DA SAÚDE, 2005).

A explicação dos manuais de medicina está reproduzida em documento do Ministério da Saúde Brasileiro (2005):

Em razão de serem, em sua maioria, chefes de família sem cônjuge, mas com filhos, a mortalidade materna de negras conseqüentemente relega à orfandade e à miséria absoluta um número significativo de crianças. As causas de morte materna estão relacionadas à predisposição biológica das negras para doenças como a hipertensão arterial, fatores relacionados à dificuldade de acesso e à baixa qualidade do atendimento recebido e a falta de ações e capacitação de profissionais de saúde voltadas para os riscos específicos aos quais as mulheres negras estão expostas (Ministério da Saúde, 2005)

Predisposição biológica que pode ser contestada pela compreensão da história e da política:

Há muita perda e demasiado sofrimento na comunidade negra. Devido às altas taxas de mortalidade infantil e homicídio, bem como de baixo índice de expectativa de vida, muitas mulheres negras têm sofrido duras perdas já na juventude. Especialistas na área de saúde física e mental indicam que perdas mal resolvidas podem contribuir para hipertensão, stress, depressão, ansiedade e uso excessivo de álcool e drogas (WHITE, 2009).

No meu caso, específico é exceção à regra, em que minha condição econômica se sobrepôs à racial, a parteira renomada que me atendia percebeu, na consulta cuidadosa do 
pré-natal meu inchaço excessivo e fez, no consultório, imediatamente, um teste de urina que detectou risco de pré-eclâmpsia. Telefonou para a obstetra da equipe que providenciou as guias de exame e, no dia seguinte, eu já estava com os resultados em mãos, que confirmavam o risco. Fui internada, tive o parto induzido por ocitocina e, tanto eu como Cecília, ficamos bem. Apesar de Outra, eu, acompanhada do Ser, de classe média, feita viver.

Em entrevista publicada pelo Portal Geledés, em 2012, a enfermeira obstétrica negra, doutora em saúde pública, Alaerte Leandro Martins, conta de dois casos emblemáticos do que acontece rotineiramente a mulheres negras. Alyne, de Belfort Roxo, na Baixada Fluminense, então com 28 anos de idade e 27 semanas de gestação, procurou uma clínica particular vomitando e com fortes dores abdominais. Recebeu a prescrição de remédios para náuseas, vitamina B12 e uma medicação para infecção vaginal. Piorou e dias depois voltou com um ultrassom mostrando que o feto estava morto. Com parto induzido, foi necessária uma cirurgia para a retirada da placenta, feita só 14 horas depois. Alyne teve hemorragia, queda de pressão arterial, foi transferida a um hospital público depois de esperar 8 horas por uma ambulância, e depois de mais algumas horas sem leito disponível, entrou em coma e morreu no dia seguinte. Cinco dias, deixada morrer, entre o primeiro sintoma e sua morte.

Marina Carneiro, aos 25 anos de idade, cursava o último ano de engenharia do meio ambiente. No pré-natal, realizado com o médico que atendia por seu plano de saúde, fez cinco ultrassonografias - mesmo sem a evidência científica de que ultrassom de rotina seja necessário para um pré-natal de qualidade e o recomendado pelo SUS seja de um ultrassom antes de 24 semanas para auxiliar a detectar gerações múltiplas ou malformações fetais (BVS, 2018) - , e nenhum exame de urina, ao contrário do que determina o protocolo básico de atendimento às gestantes - de solicitar exame de urina tipo I na primeira consulta de pré-natal (Ministério da Saúde, 1998). Com 34 semanas de gestação entrou em trabalho de parto, Manuela, sua filha, nasceu bem. Mas Marina não pode conhecê-la. Sete horas depois do parto, morreu por doença hipertensiva específica da gravidez. Provavelmente, eclâmpsia. Deixada morrer ou morta?

$\mathrm{Na}$ tese de Sueli Carneiro, depois de inúmeros exemplos de mulheres vítimas de racismo institucional na área da saúde, e de homens vítimas da violência policial, fica evidente que as tecnologias do biopoder demarcam diferentes formas de assunção do corpoalvo segundo o gênero. Mulheres negras são, fundamentalmente deixadas morrer ou são alijadas de sua capacidade reprodutiva; homens negros são mortos. 


\begin{abstract}
Assim o biopoder instala os segmentos inscritos no pólo dominado da racialidade numa dinâmica em que os 'cídios', em suas diferentes expressões os abarca, os espreita como ação ou omissão do Estado, suportado pela conivência, tolerância ou indiferença da sociedade. Extermínios, homicídios, assassinatos físicos ou morais, pobreza e miséria crônicas, ausência de políticas de inclusão social, tratamento negativamente diferenciado no acesso à saúde, inscrevem a negritude no signo da morte no Brasil (CARNEIRO, S., 2005, p. 94).
\end{abstract}

Tal como afirma Foucault: “(...) os Estados mais assassinos são, ao mesmo tempo, forçosamente os mais racistas" (Foucault apud CARNEIRO, S., 2005, p. 94 ).

O filósofo camaronês Achille Mbembe passou a ser conhecido no Brasil a partir de 2018, quando seu ensaio Necropolítica, de 2003, foi traduzido para a língua portuguesa (MBEMBE, 2018). Em um percurso parecido com o que Sueli Carneiro traça no capítulo 2, da primeira parte de sua tese, O Biopoder: negritude sob o signo da morte, Mbembe apresenta a definição de biopoder de Foucault e se dedica a explicá-la em detalhes, com exemplos históricos e contemporâneos. Na metade do texto, apresenta o que denomina Necropoder e ocupação colonial na modernidade tardia. A necropolítica, definida por ele como as formas contemporâneas que subjugam a vida ao poder da morte, foram reconfiguradas na atualidade nas relações entre resistência, sacrifício e terror. Utilizando-se de exemplos do Kosovo, Palestina e o continente africano, afirma que a noção de biopoder é insuficiente para dar conta das formas contemporâneas de submissão da vida ao poder da morte.

A noção de necropolítica daria conta das diversas maneiras pelas quais, no contemporâneo, as armas de fogo provocariam destruição máxima de pessoas e criariam 'mundos de morte', com novas formas de existência social, "nas quais vastas populações são submetidas a condições de vida que lhes conferem o estatuto de "mortos vivos"" (MBEMBE, 2018, p. 71).

Chama especial atenção sua afirmação de que as maneiras de matar não variam muito. E que, em massacres, os corpos sem vida são reduzidos rapidamente à condição simples de esqueletos, que não causam qualquer tipo de incômodo ou inquietação, apenas corporeidades vazias. Cita o caso do genocídio de Ruanda, em que um grande número de esqueletos foi preservado em estado visível, mas em alguns casos exumados para estarem visíveis. Para Mbembe: "o surpreendente é a tensão entre a petrificação dos ossos, sua frieza (coolness) estranha, por um lado, e por outro lado seu desejo persistente de produzir sentido, de significar algo" (MBEMBE, 2018, p. 60-61). 
Diante da afirmação, eu poderia supor que Achille Mbembe não leu $A$ mulher de pés descalços da escritora ruandesa Scholastique Mukasonga (2017). No final do livro, a autora descreve um pesadelo, em que muitos meninos e meninas saem de uma sala de aula para uma estrada, a mesma que levava a um acampamento militar na fronteira de Ruanda com o Burundi. Mukasonga, criança, está entre suas amigas e ela sabe que estão indo colher flores brancas, como o padre e a catequista pediram.

E as crianças estão ao pé de uma colina toda branca que está coberta de flores brancas. As crianças correm, correm pela encosta da colina. Eu não quero ir atrás delas. Não sou mais uma menina. Eu grito: 'Não subam aí, essa colina está cheia de pedras cortantes: é a colina de Rebero, onde mataram todos'. As flores brancas se mexem quando as crianças passam. Elas rangem, chiam, crepitam, estalam feito madeira seca. Eu tampo os ouvidos e grito: 'Voltem para casa, crianças, voltem...'

$\mathrm{Na}$ igreja, as crianças carregam buquês, montes, braçadas e feixes de galhos brancos. Digo a elas:

- Essas não são as flores que vocês colheram...

- Não, me diz Cândida, mas veja o que deixamos na frente do altar de Jesus, na frente da estátua de Maria.

Ao pé do altar de Jesus, ao pé da estátua de Maria, vejo vários montes de ossadas: esqueletos de homens, de mulheres, de crianças de Nyamata espalhados pelo chão da igreja.

— Vocês reconhecem quem são? pergunta Cândida. Olhe bem, eles estão aqui e eu estou com eles, você reconhece os seus? Reconhece Stefania?

Cândida é apenas uma sombra cada vez mais tênue e a voz dela é só um eco distante:

- Você tem um pano grande suficiente para cobrir todos eles... para cobrir todos... todos...? (MUKASONGA, 2017, p. 156).

\section{Resistência, escrita de si e cuidado do outro}

Todo poder gera resistência, segundo Foucault. A resistência, portanto, seria parte integrante dos dispositivos de poder. Resistência que se materializaria em estratégias de confrontação dos modos de sujeição ao dispositivo de racialidade/ biopoder.

Traçando a genealogia dessa resistência, Foucault chega às técnicas de si da Grécia Antiga, caracterizadas pela busca por uma estética da existência, indissociável do cuidado do outro. Se o poder opera nos modos de sujeição, a resistência a ele é possível pelas fissuras, nos momentos disruptivos, que oferecem a possibilidade de um estado de suspensão, de uma liberdade que se cumpre no exercício da criatividade, da sensibilidade, da beleza, nas artes da existência, no cuidado de si. 
Tais modos de subjetivação possibilitariam inventar novos modos de existência, construídos a partir das relações para consigo mesmo e para com o outro, capazes de escapar às tecnologias de controle da biopolítica, compreendendo que o Estado investe no controle da vida de indivíduos e populações. Modos de subjetivação como resistência aos modos de sujeição (RAGO, 2013, p. 43).

A resistência de negras e negros ao dispositivo de racialidade e ao biopoder se dará em primeiro lugar, para Sueli Carneiro, por meio de estratégias de sobrevivência física, seguida pela superação da ignorância racional, e no estabelecimento de uma ruptura com os discursos de dominação racial.

(...) posto que o anjo da morte do biopoder impõe, para a racialidade dominada, o manter-se vivo como o primeiro ato de resistência. Portanto, ao permanecer vivo, seguem-se os desafios de manutenção da saúde física, de preservação da capacidade cognitiva e por fim o de compreender e desenvolver a crítica aos processos de exclusão racial e, finalmente, encontrar e apontar os caminhos de emancipação individual e coletivos. Poucos são capazes de completar a totalidade (CARNEIRO, S., 2005, p. $150)$.

Sueli Carneiro ressalta que, nas condições de marginalização social a que a maioria de negras e negros se encontra submetida, a reprodução básica da vida, de poder se alimentar, não sucumbir às doenças e às técnicas de morte é a resistência possível. Somente determinados sujeitos "que encarnam, com suas vidas, uma memória ancestral, o processo tortuoso de construção da identidade, os enfrentamentos com o racismo e a discriminação, a tomada de consciência individual e da dimensão política e coletiva desse processo, a construção da crítica e da autonomia" têm condições de exercer o cuidado de si.

Nas palavras da autora:

Práticas que dizem respeito à desconstituição dos saberes e formas de assujeitamento impostas pelo dispositivo e pelo epistemicídio que fundam os sujeitos políticos que eles são, nos quais se desloca a noção do cuidado de si para o cuidado dos outros, constituindo uma estética da existência que tem na emancipação coletiva da racialidade sujeitada, o sentido da vida (CARNEIRO, 2005, S., p. 324).

Pelas estéticas da existência, artes do viver e técnicas de si, podem ser experimentadas práticas de liberdade, não de sujeição às práticas disciplinares. A escrita de si é apresentada por Foucault como uma dessas tecnologias, desde os gregos: 
Parece não haver dúvida que, entre todas as formas que tomou este adestramento (o que comportava abstinência, memorizações, exames de consciência, meditações, silêncio e escuta do outro), a escrita - o fato de se escrever para si e para outrem - só tardiamente tenha começado a desempenhar um papel considerável. Em todo o caso, os textos da época imperial que se referem às práticas de si concedem uma grande parte à escrita. É preciso ler, dizia Sêneca, mas escrever também. É Epicteto, que, todavia não ministrou senão um ensino oral insiste repetidas vezes no papel da escrita como exercício pessoal: deve-se 'meditar' (meletan), escrever (graphein), treinar; 'possa a morte arrebatar-me enquanto penso, escrevo, leio' (FOUCAULT, 1992).

Este trabalho, longe de tratar de múltiplas formas de resistência ao racismo, conformado pelo dispositivo de racialidade/biopoder, vai se dedicar a uma possibilidade dentre as estéticas da existência: a escrita de si.

Margareth Rago, em seu livro sobre a escrita de si de mulheres feministas chamado A aventura de contar-se (2013), compreende a escrita de si como um cuidado de si e também de abertura para o outro. A escrita de si seria uma chave analítica para pensar as práticas e a resistência "de quem se recusa a ser governada" (RAGO, 2013, p. 55).

Sueli Carneiro propõe uma ampliação nos sentidos de cuidado de si. Visto que os discursos e práticas em torno da racialidade comportam uma moral ou uma ética, e que as normatizações constituem um código de conduta explícito ou implícito do qual derivam os estereótipos associados aos negros, "o cuidado de si não se trata apenas da construção de uma subjetividade centrada na adesão livre a um estilo que quer dar à sua própria existência, mas, sobretudo, por voltar-se à construção de sujeitos coletivos libertos dos processos de subjugação e subalternização". (CARNEIRO, S., 2005, p. 303). "O cuidado de si se realiza para esses sujeitos no cuidado do outro, cuja libertação é a estética de suas existências."

Compreendendo mulher negra como as pretas e pardas que se colocam como sujeito político insurgente frente às discriminações de raça, gênero e classe, a escrita de si de mulheres negras, portanto, é compreendida como a formulação estética da própria existência e trabalho de memória, que possibilita a constituição de subjetividades e sujeitos coletivos que permitem escapar aos processos de subjugação do dispositivo de racialidade e do biopoder.

A produção de conhecimento a partir de sua própria perspectiva se contrapõe ao epistemicídio, tanto pela circulação do conhecimento por elas produzidos, como por serem reconhecidas como produtoras de conhecimento. A escrita de si de mulheres negras configura-se como cuidado do outro e forma de resistência ao racismo. 
Esta escrita política do que se vive, de autoria de mulheres negras, na afirmação de um sujeito político que se contrapõe ao racismo e ao sexismo, Conceição Evaristo nomeou escrevivência. Por vezes cometi o erro de interpretar escrevivência como a escrita do que se vive, sem a compreensão política da noção proposta pela autora. Em maio de 2019, em uma intervenção de Conceição Evaristo no Festival Literário de Iguape fui corrigida por ela publicamente ao mediar a mesa. Das palavras-chave anotadas em meu caderno, apreendo o sentido geral do que disse Conceição Evaristo, não suas palavras exatas: escrevivência diz respeito exclusivamente às mulheres negras, às que escrevem a partir de uma perspectiva própria, de insubmissão frente às discriminações de gênero, raça, frequentemente classe.

Já em 2005, a escritora, doutora em teoria comparada, havia escrito em um artigo:

\begin{abstract}
Assenhoreando-se 'da pena', objeto representativo do poder falocêntrico branco, as escritoras negras buscam inscrever no corpus literário brasileiro imagens de uma autorrepresentação. Surge a fala e um corpo que não é apenas descrito, mas antes de tudo vivido. A escre(vivência) das mulheres negras explicita as aventuras e as desventuras de quem conhece uma dupla condição, que a sociedade teima em querer inferiorizada, mulher e negra (EVARISTO, 2005, p. 205).
\end{abstract}

A estética da escrevivência é a estética da existência: possibilidade de escapar às políticas de biopoder. Escrita de si como resistência ao racismo.

\begin{abstract}
Escrever pode ser uma espécie de vingança, às vezes fico pensando sobre isso. Não sei se vingança, talvez desafio, um modo de ferir o silêncio imposto, ou ainda, executar um gesto de teimosa esperança. Gosto de dizer ainda que a escrita é para mim o movimento de dança-canto que o meu corpo não executa, é a senha pela qual eu acesso o mundo (EVARISTO, 2005, p. 20).
\end{abstract}

Escrita de si também é um termo utilizado por Giovana Xavier. Tanto o Grupo Intelectuais Negras UFRJ, que coordena desde 2014, quanto a disciplina "Intelectuais negras: saberes transgressores, escritas de si e práticas educativas de mulheres negras", que oferece na Universidade Federal do Rio de Janeiro têm esta noção como central.

Tomando como premissa que o racismo no Brasil se configura pelo dispositivo de racialidade e biopoder, e que o epistemicídio é uma das faces dessa configuração, assumimos também que mulheres negras, como sujeito político, resistem ao racismo por meio do cuidado de si e dos outros. Dentre as múltiplas possibilidades de cuidados de si e dos outros, destaco neste trabalho a escrita de si, compreendida como formulação estética da própria existência e trabalho de memória. 
A hipótese é de que a escrita de si de mulheres negras possibilita a constituição de subjetividades e de sujeitos coletivos que permitem resistir ao racismo, ao buscar escapar dos processos de subjugação do dispositivo de racialidade e do biopoder; ao produzir conhecimento de uma perspectiva própria; e ser reconhecida como produtora de conhecimento. 


\section{A ESCRITA QUE É LUTA, OU A LUTA ESCRITA}

$\mathrm{O}$ ato de escrever sobre si mesma de cada uma dessas mulheres, por si só, já pode ser compreendido como ato de resistência ao racismo. Mas, além da atividade da escrita de si por elas mesmas, os textos analisados tratam das temáticas da resistência. Apresento fragmentos dessa escrita que é resistência ao racismo ao mesmo tempo que conta, como se pode constatar nas análises abaixo, a resistência ao racismo.

Vale afirmar que a análise aqui apresentada diz respeito às resistências ao racismo, conforme explicitadas e argumentadas acima. Tantos outros aspectos passíveis de interpretação nos textos ricos e polissêmicos das diversas autoras podem e devem ser analisados em outros trabalhos.

\section{Sobrevivência física, preservação da saúde e da capacidade cognitiva}

Eu tinha 7, 8 anos e todos os dias tínhamos que esperar minha mãe chegar da casa das patroas com a comida para a gente comer. Às vezes, ela ficava até uma semana sem ir em casa e a comida acabava; às vezes, ela deixava o dinheiro para a compra, mas minha tia, que tinha uns 'problemas de cabeça', guardava o dinheiro e não sabia onde. Eu, danada que era, sempre encontrava bolos de notas de dinheiro nas frestas ou nos buracos dos tijolos dos barracos onde morávamos, entregava para minha mãe, mas ela ficava muito brava e xingava minha tia, pois o dinheiro não valia mais. Viviam trocando a moeda de nosso país. (...)

Todos os dias íamos no lixão perto de casa catar o que comer. Só não fazíamos isso quando minha mãe recebia o salário ou ganhava mantimentos em seus empregos, daí era festa! O barraco ficava alegre, com o cheiro bom das comidas!

Morávamos na favela Alto do Minério. Tínhamos que subir uns morros enormes para chegar até lá. Lá embaixo era o bairro de Santa Efigênia, ao lado do Quartel General, região central de Belo Horizonte, a capital de Minas Gerais.

Nos lixões, minha tia catava feijão com caruncho, uns bichinhos pretos que voavam quando a gente colocava o tabuleiro com o feijão no sol ou andavam e sumiam. Eu achava incrível como eles fugiam com o calor do sol. Tinha vez que, depois de pronto, o feijão ficava com um caldo ralo e um gosto ruim, mas a gente tinha que comer assim mesmo, era o que tínhamos (PILAR, 2019, p. 163-164)

O fragmento acima, extraído do texto Frango Verde, que Tula Pilar escreveu para o livro Inovação Ancestral de Mulheres Negras (SANTANA, B., 2019a), permite visualizar mais de um aspecto do que Sueli Carneiro enumerou como primordial ao tratar da resistência de negras e negros ao dispositivo da racialidade e biopoder. Para que a família 
fosse mantida viva, o principal desafio era a alimentação, e voltaremos a falar desse aspecto crucial da resistência, tão presente na memória de mulheres negras, adiante.

(...) posto que o anjo da morte do biopoder impõe, para a racialidade dominada, o manter-se vivo como o primeiro ato de resistência. Portanto, ao permanecer vivo, seguem-se os desafios de manutenção da saúde física, de preservação da capacidade cognitiva (...) (CARNEIRO, S., 2005, p. 150).

No fragmento inicial, mesmo que Tula Pilar não apresente detalhes sobre a saúde e a capacidade cognitiva da tia, "uns problemas na cabeça" é expressão suficiente para compreender que tal capacidade fora comprometida.

Sobre a saúde, embora Tula não tenha escrito a respeito no texto em questão, é importante informar que a autora sofria de problemas respiratórios havia anos. E que, no processo de edição do livro, foi pelo menos cinco vezes ao hospital. Recebia uma inalação e era orientada a voltar para casa. Nenhum exame. Quase nenhuma atenção. A negligência característica do racismo que, "enquanto tecnologia de poder voltada para a preservação da vida de uns e de abandono de outros à exposição da morte, presta-se à determinação sobre o deixar morrer e o deixar viver" (CARNEIRO, S., 2005, p. 77).

Em 11 de abril de 2019, um dia antes de o livro ir para a gráfica, Tula Pilar foi deixada morrer. Aos 49 anos de idade, a mãe de Dandara, de 14 anos; Pedro Lucas, de 22; e Samantha, de 30, foi mais uma mulher negra e periférica a morrer cerca de 30 anos antes da expectativa de vida da média da população. Naquele corpo, tinha fim a resistência de toda uma vida, condensada no episódio do frango verde:

Estávamos com muita fome no dia em que minha tia fez o frango verde. Dizíamos que ela estava louca e que não comeríamos aquilo para não morrer: "Ela está doida de dar isso pra gente"... Guardamos o saco de catar e fomos jogar "amarelinha", brincar na terra. Mais tarde minha tia chamou: "entra pra dentro! Vão lavar as mãos e os pés para comer e dormir!" Quando entramos em casa nos olhamos assustadas, pois havia um cheiro bom de carne, de frango bem temperado. Até hoje sei conhecer o cheiro de um frango bem temperado depois de pronto. Ficamos cochichando: "Onde ela arrumou dinheiro para comprar carne?". Logo perguntei: "Uai, Tila, como você comprou carne para nós?". "É o frango que eu catei no lixo. Vocês não estavam com nojo? Tá pronto!". Comi na tigela azul. Que sabor! Que caldo gostoso! A gente dizia: "é o melhor frango que a Tila já fez! ", "Humm, que delícia!". Minhas irmãs mais velhas perguntaram como ela fez e ela disse que lavou bem com limão e vinagre, com bastante água quente, depois temperou com cebola, alho e sal e cozinhou na panela de pressão, matando os micróbios e, por isso, ficou gostoso daquele jeito. Nós dormimos felizes, porque comemos o 
melhor frango verde que minha tia já fez. Ela avisou que minha mãe aquela noite não ia chegar: "Só amanhã à noite a Tonica vem. Amanhã vou dar para vocês aquele arroz quebradinho que catei no lixo outro dia e a metade do frango que eu guardei no tempero, vai ficar mais gostoso. Vocês vão ver!" -Tonica é apelido de Antonia; o nome certo de minha mãe é Antonia de Sousa Ferreira.

Naquele tempo a gente rezava antes de ir dormir. Agradecemos na reza daquela noite por ter minha tia que cuidava de nós e não deixava a gente morrer de fome como morriam muitas crianças da favela (PILAR, 2019, p. 164-165).

Escritora, poeta, educadora e atriz, Tula Pilar costumava performar o espetáculo Sou uma Carolina, escrito por ela, com base no livro Quarto de Despejo, de Carolina Maria de Jesus, aqui analisado como texto clássico. A alimentação é um aspecto da sobrevivência que aparece diversas vezes ao longo do livro. No trecho destacado, Carolina mostra a dificuldade para alimentar os filhos e faz um paralelo histórico que permitiria analisar o fragmento também como crítica aos processos de exclusão racial, social e de gênero:

11 de maio

Dia das Mães. O céu está azul e branco. Parece que até a Natureza quer homenagear as mães que atualmente se sentem infeliz por não poder realizar os desejos dos seus filhos... O sol vai galgando. Hoje não vai chover. Hoje é o nosso dia... A D. Teresinha veio visitar-me. Ela deu-me 10 cruzeiros. Disse-me que era para a Vera ir no circo. Mas eu vou deixar o dinheiro para comprar pão amanhã, porque eu só tenho 4 cruzeiros... Ontem eu ganhei metade de uma cabeça de porco no Frigorífico. Comemos a carne e guardei os ossos. E hoje pus os ossos para ferver. E com o caldo fiz as batatas. Os meus filhos estão sempre com fome. Quando eles passam muita fome eles não são exigentes no paladar... Surgiu a noite. As estrelas estão ocultas. O barraco está cheio de pernilongos. Eu vou acender uma folha de jornal e passar pelas paredes. É assim que os favelados matam mosquitos.

13 de maio

Hoje amanheceu chovendo. É um dia simpático para mim. É o dia da Abolição. Dia que comemoramos a libertação dos escravos.

Continua chovendo. Eu tenho só feijão e sal. A chuva está forte. Mesmo assim mandei os meninos para a escola.

Estou escrevendo até passar a chuva, para eu ir lá no senhor Manuel vender os ferros. Com o dinheiro dos ferros vou comprar arroz e linguiça. A chuva passou um pouco. Vou sair.

Eu tenho tanta dó dos meus filhos. Quando eles veem as coisas de comer eles bradam: Viva a mamãe. A manifestação me agrada. Mas eu já perdi o hábito de sorrir. Dez minutos depois eles querem mais comida. Eu mandei o João pedir um pouquinho de gordura para Dona Ida. Ela não tinha. Mandei-lhe um bilhete assim: Dona Ida peço-te se pode me arranjar um pouco de gordura, para eu fazer uma sopa para os meninos. Hoje choveu e eu não pude ir catar papel. Agradeço. Carolina.

Choveu, esfriou. É o inverno que chega. E no inverno a gente come mais. A minha filha Vera começou pedir comida. E eu não tinha. Era a reprise 
do espetáculo. Eu estava com dois cruzeiros. Pretendia comprar um pouco de farinha para fazer um virado. Fui pedir um pouco de banha a dona Alice. Ela me deu a banha e arroz. Era 9 horas da noite quando comemos. E assim no dia 13 de maio de 1958 eu lutava contra a escravatura atual, a fome! (JESUS, 2019, p. 61-62).

A densidade das palavras de cada uma dessas escritoras torna a análise especialmente desafiadora. $\mathrm{O}$ que dizer quando quem escreve um texto de denúncia ao racismo, morre, vítima do racismo, antes de o texto ser publicado? Que palavras são suficientes para tratar da experiência da fome e da busca por alternativas alimentares para a sobrevivência como resistência? Entre a blasfêmia e a redução inadequada, sigo a esboçar teoria na esperança de que mais pessoas compreendam o genocídio denunciado há décadas pelo movimento negro brasileiro.

Tula Pilar, de sorriso escancarado por onde passava, compartilhava palavras de esperança nos encontros, saraus, espetáculos, textos. E não foi diferente em Frango Verde:

Ensinei aos meus filhos, desde quando eram bem pequenos, como minha mãe e minha tia fizeram, a sobreviver no improviso: se acabar o gás, a gente junta dois tijolos e faz um fogão à lenha. Se azedar o arroz (não tínhamos geladeira), a gente faz bolinho de arroz frito. Se coalhar o leite, fazemos bolo de fubá com canela. Se não tiver o dinheiro para pagar o ônibus, juntamos latinha, plástico Pet e levamos no ferro velho para vender. Também os ensinei, através da contação de histórias e das brincadeiras populares, a não perceberem a miséria e a fome próximas de nós e que há muitas alternativas para sobreviver na grande São Paulo (PILAR, 2019, p. 166).

Este improviso, na palavra de Tula Pilar, que também poderia ser nomeado como tática de sobrevivência, está presente em muitos dos relatos produzidos nas oficinas de escrita. Ao ouvi-los, em roda, assim que foram escritos, eu mesma fui tomada de inúmeras lembranças de infância e de narrativas de histórias que não foram vividas por mim, mas por minha mãe, minha avó, minhas vizinhas. Nas condições de precariedade econômica a que estão submetida as mulheres negras no Brasil, a sobrevivência de negras e negros é, necessariamente, resultado do emprego de táticas para garantir a reprodução básica da vida.

Lembrando que tática, segundo compreende Michel de Certeau, diz respeito à ação a partir da ausência de poder, em uma situação específica. “(...) as táticas apontam para uma hábil utilização do tempo, das ocasiões que apresenta e também dos jogos que introduz nas fundações de poder" (DE CERTEAU, 1994, p. 102). Na precariedade, mulheres negras têm percebido, ao longo dos séculos, as brechas possíveis para sua ação. Em cada situação específica, essas mulheres têm, habilmente, utilizado qualquer recurso para atender às 
próprias necessidades, às das suas famílias e comunidades. Do frango verde ao feijão com caruncho, empregando ações específicas, a tia de Tula Pilar alimentava a família.

Os fragmentos anônimos abaixo, coletados na oficina de escrita, mostram como essa é uma realidade vivenciada por mulheres negras em diferentes décadas e espaços:

Quando criança, ouve uma fase em que minha mãe não podia trabalhar, viúva e com três filhos pequenos ela nos fez sobreviver: pegava os restos de feira, tirava as partes ruins e fazia um refogado de legumes. Comíamos feijão com farinha e bolinho de chuva sem ovos no café da manhã. Hoje eu não tenho medo da vida, pois, aconteça o que acontecer, eu sei que eu saberei sobreviver.

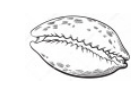

Esses dias, lá em casa, uma das raras vezes que converso com a mãe, perguntei: “mãe, aonde foi que a vó inventou o cubre?" Deixa eu dizer, é uma comida que eu saiba foi criada e só existe na família Sabino, minha família por parte de mãe.

Bom, depois de minha pergunta, eu e minha mãe começamos a pensar e tentar encontrar uma explicação, cheguei até a pensar que minha vó, sendo a mulher que sempre foi, óbvio que inventava coisas só por inventar. Enquanto o famoso cubre estava no fogo, quase que ao mesmo tempo, mãe e eu dizíamos enquanto o óbvio chegava em nossas mentes: "Ué, cubre é fácil de fazer, basicamente só o fubá, o ovo, um tiquinho de sal e açúcar, uma massa de panqueca melhorada pelos Sabinos, foi feita mesmo pra encher a barriga dos 10 filhos. E dona Maria sempre soube o que inventar e até mesmo sem gostar de cozinhar até hoje o cubre aparece nos pratos lá de casa, fazendo a gente de barriga cheia se lembrar da vó, da mãe, da saudade".

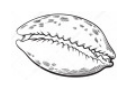

Nos mudamos, casa nova, minha avó logo fez um fogãozinho à lenha no quintal para cozinhar o feijão a fim de economizar o gás, muito caro.

Um dia minha mãe fez uma massa de bolo, quando foi assar no forno do fogão à gás descobriu que havia acabado. Para nossa surpresa, ela pegou uma tampa de panela e cobriu a assadeira de bolo e a mesma colocou no fogão a lenha de minha avó.

O bolo ficou assado como se tivesse forno normal, mas era a sabedoria de minha mãe, sempre nos surpreendendo e nos fazendo feliz com seus sabores de comer.

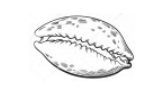

$\mathrm{Na}$ Bahia, o que mais se comia era farinha, alimento farto na terra onde vim. Todos reservavam um tempo para fazer sua farinha na casa de farinha que ficava no centro da cidade. Para dar sustança e pra fome passar, de noite, às vezes comida não tinha Então o que se comia era café com farinha. Era o que minha mãe tinha pra me dar. Hoje em dia nem café eu tomo. Acho que gostava daquele café e daquela farinha. 
Importante notar, em todos os textos, como são as mulheres as que criam soluções para alimentar o grupo. Faz lembrar o kingana banto, escrito por Fu-Kiau: Kanda diasâla nsâng n’kènto ka ditûmbukanga ko, em kikongo, traduzido por Tiganá Santana Santos como "O feminino é a vida (Deus) em e ao redor de nós", interpretado pelo próprio FuKiau como “Enquanto houver um 'rebento' feminino dentro da comunidade, ela não poderá ser aniquilada. A presença de uma mulher na comunidade é o símbolo da continuidade da vida nessa comunidade, e, ao contrário, a ausência é o símbolo de seu término." (SANTOS, T., 2019, p. 79). Empírica e filosoficamente, as mulheres são as guardiãs da vida, das pessoas e das comunidades, diretamente responsáveis pela sobrevivência física - resistência primordial ao dispositivo de racialidade e biopoder.

Em uma perspectiva da economia feminista, como ensina a socióloga e militante da Marcha Mundial das Mulheres, Tica Moreno, as condições de possibilidade da vida - que abrange tanto a satisfação de necessidades materiais como também as relações de cuidado e afeto - são construídas cotidianamente pelas mulheres (MORENO, 2019).

Essa articulação comunitária, que conforma o que podemos chamar redes de solidariedade ou redes de proteção também está presente em inúmeros escritos. A maior parte deles no tópico organização de sujeitos coletivos; com aqueles que dizem respeito especificamente à alimentação e à manutenção da saúde, aqui. Luciana Reis, no texto Mulheres equilibristas: vivências e resistências, também escreve sobre uma tia que empregava táticas para alimentar todo o grupo:

\begin{abstract}
Sua rede de proteção [da mãe de Luciana] era sempre minha tia que, no final da tarde, chegava com sacolas cheia de alimentos e, muitas vezes, vinha de brinde uma boneca de plástico com cabelo de milho para mim e um carrinho de plástico para meu irmão. Minha tia não tinha vergonha: no final da feira passava olhando debaixo das barracas, onde pegava muitas frutas e verduras boas para o consumo, e, se precisasse, pedia pra um e para outro ou até mesmo nas igrejas, não importava se evangélica ou católica, pois o importante era trazer sacoladas de alimentos para não faltar nada. Minha mãe recebia aquilo e transformava em deliciosos pratos de lamber os beiços (REIS, L., 2019, p. 109-110).
\end{abstract}

Nega Duda, em Não tem coisa boa se não lembra da ruim, conta da infância no Recôncavo Baiano, em que era possível pegar frutas no pé tanto para serem imediatamente consumidas, como para serem processadas e guardadas. Com frutas, peixes e o que era plantado na roça, mesmo que em momentos de maior escassez, a segurança alimentar de crianças maiores e adultos estava garantida. Do trabalho em limpar peixes, vinha o pouco dinheiro para arcar com as outras obrigações da vida. 
Foi uma infância danadinha. Eu brincava, subia no pé de manga, de jaca, buscava goiaba no mato, andava dois quilômetros com balde para buscar goiaba. Naquele tempo, o Recôncavo tinha goiaba para varrer o chão. A gente trazia os baldes cheios para descascar, tirar a polpa, fazer doce para guardar.

E tratava peixe com a minha mãe. Na minha terra tem um peixe chamado xangó. Não é Xangô, não, é xangó. Parece uma sardinha menor. A gente tira a espinha do meio, limpa e fica o filezinho. A moqueca é feita de três filezinhos juntos. Vai arrumando os montinhos na frigideira, tempera bem com todo o tempero da moqueca e cozinha. Desse mesmo jeito que a gente faz os três filezinhos temperados como moqueca, a gente pega um quadrado da palha da banana, dobra, amarra as pontas, depois assa no carvão: chama moqueca de folha. É original da minha cidade, São Francisco do Conde, no Recôncavo, uma cidade banhada pela Baía de Todos os Santos.

Aquele peixe é daquele que a canoa vem cheia. É muito. Na minha casa a gente tratava aquelas latas de óleo de 18 litros cheias de peixe. As pessoas pagavam para a minha mãe tratar os filezinhos - era muito trabalhoso, então as pessoas já levavam para casa aquele filezinho só para temperar, fazer e comer. A gente passava o dia todo sentada tratando peixe (DUDA, 2019, p. 146-147).

Mas, manter a saúde de bebês e crianças pequenas era um grande desafio. A mortalidade infantil ${ }^{8}$, de crianças com menos de cinco anos de idade, em 1960, era altíssima: 117,7 a cada mil. Em 2017 este número foi reduzido a 12,8. Com ações efetivas do movimento religioso-popular e a estruturação de políticas sociais, entre 1940 e 2017, a mortalidade infantil caiu 91,3\% no Brasil. Contou Nega Duda:

Eu vi vários irmãos meus morrerem por desidratação, aquela doença horrível em que as crianças ficavam pele e osso. Uma das minhas irmãs tinha um ano e seis meses quando morreu e eu tinha uns 10 anos na época. Cheguei da escola, a peguei nos braços - era só pele e osso - e ela suspirou e morreu. Minha mãe falava que ela esperou eu chegar para morrer.

Não era uma vida ruim, era uma vida boa. Quando não tinha meio dia, comia de noite, mas ninguém nunca dormiu sem nada. Depois foi melhorando, mas os maus-tratos eram constantes. Hoje eu entendo a minha mãe, mas passei muito tempo sem entender (DUDA, 2019, p. 145).

Os traumas ocasionados por tantas vivências são, por si só, outras fontes de doenças. E a escrita de si pode ser compreendida também como possibilidade de trabalhar traumas, como se verá adiante.

8 Dados do IBGE, sistematizados nas Tábuas de Mortalidade Infantil, disponíveis em: $<$ https://agenciadenoticias.ibge.gov.br/agencia-sala-de-imprensa/2013-agencia-de-noticias/releases/23200em-2017-expectativa-de-vida-era-de-76-anos $>$. 
Ainda sobre o desafio de se manter viva, e manter viva a própria comunidade, escreve Dalva Santos em Sol na casa oito:

10 de janeiro de 1983. Nasci. Eu, Dalva Regina Pereira Santos, mais uma mulher, brasileira, negra. Mais uma negrinha. Nasci prematura, com seis meses apenas, tempo curto o suficiente para que o diagnóstico fosse de um óbito também prematuro, mas a medicina formal entende pouco da vida e cá estou (SANTOS, D., 2019, p. 53).

Táticas são empregadas também na manutenção da saúde e tratamento de doenças, ao mobilizar o conhecimento ancestral de uso das ervas e outros elementos da natureza para cuidados físicos, emocionais e espirituais. As ervas "caçadas no mato", como diziam minhas avós, parar curar e benzer, são também cultivadas nos quintais, janelas e sacadas de apartamentos. Na trança das culturas africanas e indígenas, se configuram remédios preparados por infusão, chás, inalação, compressas; maceração, nos banhos, garrafadas e tinturas; além dos emplastos, óleos, amuletos, defumações, benzeduras.

Meu penúltimo irmão foi o único que nasceu no hospital. Todos os outros 14 nasceram em casa com parteiras. Ele era muito fraquinho e quando tinha quatro meses ficou muito doente e eu via minha mãe preparar um mingau de fubá e colocar quase quente em um pano. Fazia um embrulho e colocava no peito do bebê. Era emplasto, para fazer soltar o catarro do peito dele que estava com pneumonia e foi curado em casa. Depois que a morte passa ela deixa impulso para viver.

O trecho acima, produzido na oficina de escrita, mostra um conhecimento que, mais do que na transmissão oral, é atualizado de geração a geração na memória-hábito, de repetição e ajustes nos modos de fazer. O conhecimento sobre as ervas compõe uma memória coletiva, inscrita no corpo individual e no corpus coletivo de pessoas negras, constantemente ativada. E além das memórias de cura realizadas por mães, tias e avós, a figura das benzedeiras está presente nas narrativas.

As benzedeiras são pessoas conhecidas das famílias da comunidade, donas de casa, mães e avós, vizinhas, que, para retribuir o dom recebido de Deus, rezam e curam. Na sua prática devolvem o bem que receberam às pessoas que precisam. Herdaram e agora repartem a herança cultural (AGUIAR, G., 2009, p. 50).

Lívia Milena da Silva, em Travessias entre secas e girassóis, escreve sobre a tataravó, benzedeira e parteira no interior da Bahia, na Fazenda Alecrim, povoado no 
município de Pindobaçu. E Marli Aguiar, também conta em Sementes espalhadas que floescem, da avó benzedeira.

Outra forte lembrança que carrego daquele lugar é da minha tataravó, Chiquinha, como chamávamos carinhosamente. Ela foi parteira e viajava - a maior parte das vezes a pé e sozinha - por toda aquela região, de sol ardente e terra avermelhada, onde as casas eram bem distantes umas das outras, para realizar partos na casa da gestante. Era algo bem comum, pois as mulheres não costumavam ter seus filhos nos hospitais. Eu era bem pequena, devia ter uns 3 anos e não me recordo da sua fisionomia exatamente; no entanto, tenho na memória que, apesar de ela não fazer mais partos, era bem ativa e ainda benzia as crianças com mau olhado. Morava sozinha e andava pelas redondezas de sua casa. Íamos vê-la todos os finais de tarde - minha avó, meus tios Luzinete, Ronilson, Ronivon e eu. Um dia a encontramos caída no chão quente do terreiro de sua casa. Seu corpo estava cheio de bolhas. Havia passado à tarde de sol ardente ali. Logo minha avó e os demais familiares que moravam bem perto de Chiquinha e toda a vizinhança iniciaram os cuidados, ali mesmo em sua casa. Palha de banana sob as bolhas para secar, banhos, rezas... Não the faltaram cuidados, a guerreira, porém, que já havia ajudado a trazer tanta vida ao mundo, precisava descansar.

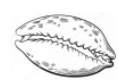

Minha avó materna, Mariana Augusta de Jesus, era dada a artista. Dizia minha mãe que ela era uma preta bonita que gostava de cantar. Ela também era parteira, ligada às ervas e às rezas. Quando levava as crianças para benzer, rezava baixinho e passava os ramos de folhas para tirar quebrante e mau olhado. Vó Mariana gostava das florestas, rios, cachoeiras. Também trabalhava no campo, filha de negros escravizados. Ela gostava de bordar, de costurar e de contar histórias. Por outro lado, vó Maria Augusta, mãe de meu pai, era de sangue nos olhos. Meu pai dizia que as pessoas a chamavam de feiticeira e macumbeira (AGUIAR, M., 2019, p. 133).

\section{Elaboração de traumas}

A violência vivida é também perpetuada por pessoas negras. Elaborar os traumas, trazendo-os à consciência, é também uma possibilidade de não reproduzir ações violentas, além de curar dores emocionais e evitar doenças no corpo físico.

Depois que você chega a uma certa idade, lê coisas, se apropria da leitura, você começa a ver que sua mãe era uma feminista daquele tempo. Uma mulher sozinha que criou 13 filhos em uma sociedade machista. A gente está falando de 1970 - eu sou de 67. E a gente está falando do interior do Recôncavo. Se aqui está desse jeito, lá o patriarcado e o machismo ainda imperam. Depois de uns anos minha mãe foi amadurecendo e maltratando 
menos os filhos, mas eu tenho marcas para sempre; fui queimada em brasa.

Você fica olhando e pensa: por que é que minha mãe fez isso? Eu sempre falo disso porque eu tenho que falar. Não tem coisa boa se não se lembra da ruim. Tenho trauma porque muita coisa da infância eu não lembro; só fui lembrar depois que minha mãe morreu. Acho que bloqueei muita coisa. Fiquei sem essas memórias. Minhas memórias eram mais com a minha avó. Minha avó era o carinho (DUDA, 2019, p. 146).

Narrar lembranças, do ponto de vista da psicologia, é uma possibilidade de elaboração simbólica de traumas. Ao analisar exemplos de sobreviventes do holocausto e seus descendentes, Jeanne Marie Gagnebin afirma que o esforço para dizer o indizível permite continuar a viver e serve também como testemunha do que deve estar presente na consciência da humanidade.

A escrita de si de mulheres negras, ao contar eventos traumáticos, permite elaborar os traumas vividos além de, ao servir de testemunho, compor uma memória coletiva que é também elaboração de um trauma coletivo. O silêncio frente às violências da escravização e do racismo deixam os traumas nas sombras, causando ainda mais violências e traumas. A elaboração escrita - seguida da leitura e do debate público - permite trazer à consciência social as dores que temos secularmente ignorado e silenciado. Lembrar para contar e esquecer, como traz o título de Jeanne Marie Gagnebin (2018), se apresenta como possibilidade de interromper a violência e superar os traumas do racismo.

Hoje, os dois são meus ancestrais. Fiz questão de começar esse texto assim, porque durante muito tempo, e ainda hoje, usar o sobrenome "Silva" é muito custoso pra mim. Acolher a história do meu pai na minha vida só foi possível quando eu já era adolescente, mais precisamente, quando pisei pela primeira vez em um terreiro de candomblé. O "Fumaça", apelido que ele recebeu ainda na infância, foi, literalmente, um vapor em minha vida, visível, principalmente em minha pele, porém pouco tangível, pois ausente nas principais fases de amadurecimento do meu corpo e da minha espiritualidade.

Minha mãe, Maria Eugenia, nunca falou mal do meu pai, mas eu sabia bem quantas lágrimas, suores e desesperos ele nos causou. Meus pais se separaram quando eu tinha 2 anos de idade, mas fiquei com marcantes lembranças dele na cabeça. Quando eu tinha por volta de cinco ou seis anos, eu e minha mãe passamos pela pior fase financeira da nossa vida. Ela desempregada, com mais de quarenta anos, dividindo-se em mil empregos informais, como vendedora de roupas, faxineira e atendente de bar. Morávamos na casa da minha avó materna, Gilda, que segurava as pontas como podia, mas não dava conta de tudo. A casa das três mulheres se esforçava para prover o necessário, o básico. Um dia, minha mãe me pegou pelo braço e fomos na feira de roupas e artesanatos que meu pai administrava para pedir ajuda. Lembro como se fosse hoje: minha mãe, em prantos, pediu a ele uma bolsa de compras e implorou por comida. 
Eu erguia a cabeça, olhava para ele e me sentia tão pequenina; em contrapartida, descortinava-se na minha frente um homem enorme, gigante. Para a menina Carolina, o "Fumaça" era o maior homem do mundo. Já adulta, verifiquei o equívoco, pois naquela época eu media 1 metro e $78 \mathrm{~cm}$ e descobri que ele tinha apenas 10 centímetros a mais do que eu. Fantasias de criança, minha vó diria. Voltando aos anos 90, eu admirava aquele homem enorme, mas ele sequer me via. A única coisa que disse a minha mãe foi: "você está nessa vida porque quer, Eugenia". Esta foi a penitência imputada a minha família. O erro-crime da minha mãe? O divórcio, é claro! Alfredo - seu nome de batismo - nunca admitiu ser rejeitado, nem mesmo após minha mãe ter descoberto uma outra esposa e filha dele (ROCHA, 2019, p. 41-42)

Os traumas, como se pode notar nos fragmentos acima são causados por razões diversas, propagados também por pessoas negras. Mas, é nas relações inter-raciais que as discriminações acontecem, gerando também traumas. Dalva Santos escreve sobre a infância em uma família branca, de classe média alta, no Rio de Janeiro, apresentada pela mulher branca a quem chamava mãezinha como "a menina que eu crio". Lívia Milena da Silva mostra como a escola é local de discriminação e trauma, como elabora longamente Sueli Carneiro em sua tese.

Fui criada por uma família branca, de imigrantes italianos, classe média alta, servidora pública do Rio de Janeiro. Meu pai sempre foi extremamente presente, mas mesmo com todo afeto, referência, proteção ele não pôde conter a força invisível do embranquecimento. É incrível como a proposta de uma "vida melhor" ainda é um projeto velado de branquitude. Uma áurea difusa de uma pseudo aceitação que mina aos poucos a percepção que temos de nós mesmas. É como viver em cativeiro com a porta aberta. É como ser forçada a ter gratidão pelo algoz. Uma menina liberta, mas que aprendeu a ser presa. E acho que é exatamente isso que fala muito do Brasil, um país subserviente, escravo de si mesmo (SANTOS, D., 2019, p. 54-55).

No final de 1998, minha mãe foi nos visitar. Eu já tinha 9 anos e o meu tio mais novo, 12. Minha mãe ficou preocupada com o fato de nós dois estarmos fora da escola - a roça era muito longe da cidade. Então, nos organizamos para morar na cidade: uma sobrinha da minha avó, Josinete, emprestou uma pequena casa e minha mãe ficou de contribuir todo mês com um valor. Assim, no começo de 1999, eu comecei a estudar. Eu tinha muita dificuldade. Tinha um atraso gritante em relação aos demais colegas mais novos do que eu, além da dificuldade de me relacionar com as outras crianças. Mas eu tinha tanta, mas tanta vontade de estudar... Desde muito nova, estudar exigiu muito esforço. Eu tinha aprendido com a minha tia Luzinete a apenas escrever meu nome por extenso. A professora não ajudou muito. Em vez de me auxiliar em minhas dificuldades e entender o contexto, me expunha para a classe: "Se não sabe, não faz". Fiquei tão triste, mas não contei pra ninguém. Nem para minha avó. Guardei para 
mim. Aqui começava o meu silenciamento diante das opressões (SILVA, Lívia, 2019, p. 78).

Nos relatos acima, a condição racial está intrinsecamente conectada também à condição social das escritoras. Mas aspectos que explicitam a condição de gênero dessas mulheres negras aparecem, especialmente, nas narrativas de traumas relacionados à violência doméstica e a abusos sexuais na infância. Um trauma comum a mulheres negras e não-negras que se agrava nas condições de escassez material e discriminação racial.

A violência externa era temida. Os mais velhos sempre contavam casos de algum tipo de violência sofrida, na sua maioria, por meninas e mulheres. Porém, muitas dessas violências vinham de quem tinha por obrigação a proteção. Minha mãe mantinha uma proteção especial comigo nesse sentido, mas não foi o suficiente para afastar os que poderiam me molestar. Nos últimos tempos, vieram à minha memória dolorosas lembranças desse tipo de violência. Era o que minha mãe mais temia e, sem que ela pudesse evitar, acontecia debaixo de seu olhar de pai e mãe.

Não foi uma nem duas vezes. Não sabia como me livrar daquilo, pois sentia medo, vergonha. Não entendia o que estava acontecendo, não me recordo com clareza a idade, mas tenho certeza de que não tinha mais do que 9, 10 anos de idade. Sem entender direito o que acontecia e incomodada com aquilo, contei para uma prima na esperança que acabasse. Veio a orientação: "Nunca fique sozinha no mesmo lugar com ele, procure sempre fugir. Se eu estiver por perto me chame, mas não conte nem para sua mãe nem para seu primo (o filho da minha tia Carminha era como irmão mais velho e pai). Se contar a eles, com certeza o matariam, eles seriam presos e você ficaria sem mãe e primo. E quem cuidaria de você e seu irmão?". Entendi aquilo tão bem, tão pequena, mas forte o suficiente para criar estratégias para que o "monstro" não tocasse mais em mim. Acredito que o medo de perder as únicas pessoas que zelavam por mim também era muito grande. Internalizei esses episódios da minha vida de tal forma que, como já foi dito, me recordei há pouco tempo disso tudo. Não poderia correr o risco de ficar sozinha no mundo e ir para um "orfanato" - assim que se chamavam os serviços de acolhimento na época (REIS, L., 2019, p. 108)

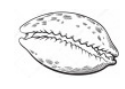

As vozes também murmuravam coisas que não dava para entender. Tinha medo delas entrarem para pegar a mim e aos meus irmãos. Muitas vezes, eu, tomada de uma coragem instantânea, gritava: “quem está aí?". Para meu desespero, a voz respondia e eu sabia que era o coisa ruim que tinha chegado. Me voltava a orações mentais, pedindo para que ele voltasse para o bar, de onde nunca deveria ter saído. Graças ao pessoal do céu, minha mãe chegava, o que era triste e feliz ao mesmo tempo, porque o coisa ruim falava coisas horríveis e a violência comia solta. Eu me armava de rodos e panelas e todas as vezes que me era possível acertava a cabeça dele. Raras vezes ele trazia um doce ou desmaiava bêbado, favorecendo o saque. No outro dia teríamos dinheiro para a mistura. 


\title{
$(\ldots)$
}

Os vultos e as vozes vão pouco a pouco entrando pelas frestas das portas e janelas, se derretem no chão, entrando derramadamente por debaixo da porta, grudam na parede e pouco a pouco vão adentrando o nosso quarto uma sensação de morte desperta a menina bruscamente. Com a cabeça coberta, mas prevendo o pior, ela tenta enfrentar o medo e encarar o vulto frente a frente. Num misto de ousadia e desespero, ela descobre a cabeça e vê um vulto se aproximando com a cabeça coberta com um vestido dela, que ela havia passado para ir à escola no dia seguinte. O terror toma conta do coração, a figura aparenta ter uns dois metros de altura, o coração dispara e congela a voz e o movimento daquele corpo. A cada passo um som ofegante e rouco e um cheiro de mundo invade seu olfato e em mais alguns passos ela sente que irá morrer. Os braços não funcionam, a voz não sai e as lágrimas correm molhando o travesseiro feito de roupas enroladas. Ela está cara a cara com o vulto e nada vê com suas vistas marejadas de lágrimas. A raiva transmuta no xadrez do seu vestido, a mão do vulto puxa a blusa da menina e começa a acariciar seus pequenos seios, correndo por todo o corpo e, nesse momento, acontece o apagão.

Na manhã seguinte o vestido está estendido no chão. A luz do sol entra pelas mesmas frestas dos vultos e tudo parece voltar ao normal. A dor no corpo, os olhos inchados, a garganta inflamada e nenhuma vontade de usar aquele vestido. A vó grita lá embaixo:

- Corre, menina, você vai perder o horário da sua aula. Você gosta tanto de estudar, levanta, vamos à luta!

Eu corria. Ir para a escola era um momento que eu tinha para mim (ROMIO, 2019, p. 64-66).

\section{Organização de sujeitos coletivos}

\begin{abstract}
A iyalorixá de São Gonçalo criara uma Casa de Candomblé a qual, além dos misteres religiosos, tinha por objetivo dar abrigo aos filhos de santo menos favorecidos.

Mãe Aninha costumava dizer a sua "irmã carnal" Andreza que criara a Roça para Xangô e seus filhos de santo. Ela era passageira; o "Axé”, não. Muitas famílias construíram residências no terreno da "Roça"; não só famílias, aliás, como, também, pessoas sós e desamparadas. Oba Biyi doou-lhes espaços para que edificassem suas casas. Filhos de santo em dificuldades financeiras eram discretamente socorridos pela iyalorixá (OXOSSI, 2019, p. 105).
\end{abstract}

No fragmento do texto de Mãe Stella de Oxossi está ilustrado o papel que casas de candomblé e famílias de santo exerceram, ano longo da história de negras e negros brasileiros, e seguem exercendo. Além do cuidado espiritual tão importante para que chegássemos até aqui, as relações econômicas, redes de troca, solidariedade e apoio se constituíram no Candomblé.

Também a este respeito escreveu Carolina Rocha, filha de Xangô, em Coisa de preto: ancestralidade, criatividade e magia: 
O candomblé me ensinou sobre amor, sobre fé e sobre a economia das alquimias. O terreiro é um espaço de acolhimento em que a cura, seja através da comida, das ervas ou dos rituais, se multiplica de forma incrível. Fora a quantidade de empregos que são gerados, os cargos religiosos também são a possibilidade de aprendizagem de ofícios. O Ogan, que toca o atabaque para os orixás, também oferece cursos de percussão para se sustentar, a Ekedi - mãe do orixá -, que cuida das roupas sagradas, é a mesma que também pode costurar para se manter. A Iyabassê, responsável pelo preparo dos alimentos, faz quentinhas para vender durante a semana. $O$ filho de santo que aprende a fazer os ornamentos de decoração da casa e as ferramentas dos orixás pode trabalhar com artesanato fora dela, dentre tantos outros exemplos. Como professora, eu dava aulas de alfabetização dentro do terreiro e, como troca, uma das mães dos meninos que estudavam comigo criava e costurava as roupas do meu orixá, pois eu não tinha como pagar. Assim, toda uma rede de apoio e economia solidária é constituída dentro desse espaço e com a comunidade que existe a sua volta. Em tempos de criminalização do abate ritual religioso, é preciso lembrar que os animais sacralizados nos rituais são comidos pelas pessoas e alimentam famílias inteiras. É uma outra forma de constituir o sagrado e as relações, diferente da cultura branca e ocidental capitalista que nos cerca (ROCHA, 2019, p. 47).

A palavra Candomblé, antes de dizer respeito à religião, já significou reunião de negras e negros. Além dos cultos a orixás, nkisis caboclos, voduns, o candomblé é comunidade. Pode-se aqui estabelecer uma relação entre a origem do termo candomblé, com kanda, palavra da língua kikondo que significa comunidade ou família. Como já dito anteriormente, família que extrapola vínculos consanguíneos. Uma família ou comunidade é, na língua bantu, um registro de informações, saberes, imaginários e compartilha, desse modo, uma simbologia comum. A comunidade é composta por pessoas, pelo tempo, pela cultura (SANTOS, T., 2019). Deste modo, podemos afirmar que as comunidades se constituem na mesma experiência compartilhada.

No texto de Lívia Milena da Silva, o depoimento de uma filha de empregada doméstica que se ausenta do convívio familiar, para fazer os trabalhos de limpeza, cozinha e cuidados para famílias brancas de classe média. Realidade que permanece no Brasil desde o período escravocrata, atualizada todos os dias nas casas de classe média e alta, e também na ausência física dessas mulheres em suas famílias e comunidades.

Quando eu tinha por volta de 5 anos, minha mãe foi morar em São Paulo. Essa notícia chegou a nós por carta. A minha avó lia a carta soletrando e eu e meus tios ouvíamos bem atentos - a gente ainda não sabia ler. Dentro do envelope da carta ela pôs dinheiro. Nunca deixou de mandar, por menos que fosse. $\mathrm{O}$ valor era sempre usado em benefício de toda a 
família. A partir desse momento, suas visitas passaram a ser mais raras (SILVA, Lívia, 2019, p. 77-78).

Nas comunidades negras, especialmente em situação de pobreza, são abundantes os relatos de partilha de recursos materiais e constituição de redes de solidariedade, o que pode ser afirmado como organização de sujeitos coletivos. Lembro bem como, na infância, o trabalho com carteira assinada de minha mãe significa segurança alimentar não apenas para mim, meu tio e avó, mas também para as vizinhas e vizinhos que precisavam de dinheiro para a cesta básica, a conta de luz, o gás.

Minha mãe, Maria de Jesus Pereira Santana, por incentivo de Maitê Freitas, foi uma das mulheres negras a receber o convite para escrever. Agradeço à comadre pela sensibilidade em reconhecer a importância de trazer a voz de quem veio antes de mim, por onde passa minha ancestralidade, em um trabalho que trata de memória, origens, antepassados, ancestralidade. No texto escrito por ela, há também menção às lembranças da COAHB que me são caras.

(...) Minha mãe [Apolinária] ficava feliz em arrumar o jardim antes cheio de pedras e matos. Ela cuidou muito bem e ficou lindo. Moramos lá por 11 anos, um dos períodos mais lindos da minha vida. Alguns vizinhos tinham problemas financeiros e às vezes faltava dinheiro para o gás, mas sempre tínhamos como ajudar a todos, em todos os aspectos" (SANTANA, M., 2019, p. 125).

A rede de ajuda mútua também se materializa na oferta e troca de cuidados, serviços e outros recursos além dos financeiros. Quando eu brincava na rua em frente ao prédio, era sempre cuidada por alguma vizinha (Lucia e Sandra, que saudade!); nas poucas oportunidades de usar piscina na infância, fui levada a um clube por outros vizinhos (seu Mário e dona Zilda, agradeço muito!); e minha avó, que detestava limpar o fogão, sempre recorria à Nega, vizinha adorada do segundo andar, para cumprir a tarefa. No texto de Cleo Dias, a partilha dos cuidados é mencionada:

Após o resguardo, minha mãe já voltou a trabalhar em casa e na roça. Ela me levava junto, me deixava em baixo dos pés de café e o cuidado era meio que coletivo: entre uma rua de café e outra, alguém passava para dar uma olhadinha. A lida da roça era das cinco horas até o anoitecer (DIAS, 2019, p. 49).

Três relatos produzidos na oficina de escrita, também mostram o vínculos solidário das famílias expandidas e comunidades, até mesmo os excluídos de uma comunidade: 
As crianças todas da rua tínhamos medo da Anastásia. Era escura, suja, meio bêbada, meio louca, falava sozinha, dormia nas ruas e surgia do nada.

Teve aquele inverno que fazia frio, muito frio em Bauru. Não é cidade de frio, e ninguém estava preparado, muito menos a Anastácia.

Quando minha mãe chegou da missa, a Anastácia estava dormindo em frente ao bar do meu pai, tentando se aquecer como podia. A mãe entrou, a mãe rezou e saiu. Voltou com a Anastácia: "temos uma hóspede neste inverno."

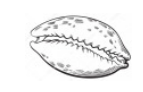

A separação estava posta depois de 15 dias na casa da minha tia, minha mãe, depois de muita procura, encontrou uma casa. Era bem pequena.

Em meio a essa situação de recomeço só tínhamos a casa alugada, já que nossas coisas estavam todas com meu pai. Foi um verdadeiro mutirão. Cada parente nosso que chegava para ver nossa conquista ajudava com o que tinha. Tia Luiza com as panelas, minha prima com mesa e cadeira minha tia Maria com os pratos. Hoje em dia, depois dessa fase, até hoje temos muito carinho.

Dia esperado de pagamento. O banco só no centro da cidade. Passagem contada para uma pessoa. Uma pessoa com dois filhos pequenos. Uma menina e um menino. $\mathrm{O}$ sol esquentava o asfalto, fazia os pés das crianças em tênis conga suarem. O primeiro ônibus passa lotado. A mãe ansiosa segurava os filhos pelas mãos. Segundo ônibus, cheio, mas conseguiram que coubessem mais de dez pessoas. A primeira criança mais magrinha passa por debaixo da catraca sem dificuldades. Já o menino maior e robusto ficou vermelho de não conseguir passar o quadril.

O ônibus cheio, o cobrador dizendo pra mãe se virar. A mãe suava, suava. Eis que a vizinha na porta que quase não fechava grita:

- $\mathrm{O}$ comadre, eu tenho um troco aqui.

Carolina Rocha mostra como as comunidades são constituídas nos diferentes espaços e situações incluindo a universidade pública pós-cotas raciais.

Eu a ajudava no bar nos fins de semana e feriados e assim ganhava gorjetas para custear a passagem e as "xérox" de textos. Ah, essas "xérox" eram o pesadelo dos alunos na universidade. Entrei na Universidade Estadual do Rio de Janeiro (UERJ) em 2006 e, para driblar a falta de grana, minha turma de Serviço Social (curso noturno e, majoritariamente, cotista) fazia rodízio dos textos para ler e assim só precisávamos comprar uma cópia de cada. Também rolava rodízio de comida: cada dia um levava um lanche para ser partilhado. Vi colegas desmaiarem de fome nessa época, pois trabalhavam o dia todo e depois iam com fome para as aulas. Eis a manutenção no espaço acadêmico, o grande desafio das cotas. A universidade pública é cara, muito cara. Depois saí do Serviço Social e fui para a História, na Universidade Federal Fluminense (UFF), onde a 
rede de ajuda mútua continuou para que sobrevivêssemos. Eu vendia livros usados para me manter (ROCHA, 2019, p. 46).

A rede de ajuda mútua também mobiliza recursos profissionais entre mulheres negras autônomas e artistas, conforme é possível ler no relato de Luana Bayô, Mulher negra: uma vida entre o sonho e a realidade, e Lucia Makena, Resistência, luta e conquista.

\begin{abstract}
Algumas vezes eu reclamo que o corpo está cansado, tem os boletos para pagar, água, luz, as dívidas feitas para bancar esse sonho: músico, estúdio, transporte, alimentação, produção. Minha mente pede arrego e digo a elas que, mais uma vez, acho que não vai dar. Elas, sabiamente, usam dos seus conhecimentos ancestrais e me relembram da minha verdadeira natureza e do porquê eu e elas estamos ali. Olho para elas e me vejo. Elas, mulheres negras, que também têm seus sonhos, seus dons, suas vontades. Uma é poeta e deseja lançar seu livro; a outra, jornalista e grande produtora. Também tem a amiga da infância, secretária que deseja terminar os estudos em mídias digitais. Assim como eu, elas estão tentando equilibrar sonho versus realidade. Até que a realidade vire um sonho. Elas tiram um tempinho na agenda, que é apertada, e também saem cedo de casa e só retornam quase na madrugada. Elas estão lá. Eu também estou lá no sonho delas.

Mesmo sem serem especialistas, elas ajudam naquela filmagem no celular antigo, ou até naquela foto só para "registrar o momento". Marcam um ensaio, a outra vende um show, indica o trabalho de uma para outro projeto, escreve um release, divulga aquele trabalho ou aquela poesia na rede. Enfim, são várias permutas. Muitas formas de se ajudar (BAYÔ, 2019, p. 86).
\end{abstract}

Com o fortalecimento da rede de amizades com empreendedoras negras que fazem roupas afro começaram a surgir os retalhos para fazer roupas para as bonecas e, aos poucos, fui usando esses retalhos para vários estilos de bonecas, inclusive para as bonecas Abayomi, que são confeccionadas com retalhos tanto no corpo como nas roupas. Nós não temos dinheiro para dar umas para as outras, mas conseguimos nos ajudar de outras formas, como circulando uma parte do dinheiro entre nós, comprando roupas, bonecas, acessórios, enfim. Assim vamos nos fortalecendo.

Atualmente, tenho em casa retalhos de quatro marcas de confecções próprias e, dependendo dos retalhos, consigo dividir com várias pessoas, inclusive levando resíduos para entidades que confeccionam pequenas peças ou almofadas. A economia que tenho com esses retalhos me possibilitou a oportunidade de comprar tecidos para fazer o corpo da boneca em quantidades bem maiores como 30,40 ou 70 metros de uma vez. Além disso, para o enchimento do corpo consigo comprar 10 ou 20 quilos de uma vez, ao invés de um ou dois quilos (MAKENA, 2019, p. 98-99). 
Miriam Nobre apresenta as lentes da economia feminista para analisar a importância que as tias, na constituição de comunidade na família expandida, tiveram em sua vida e na de outros familiares, ao colocarem todos os recursos que tinham disponíveis em benefício do grupo:

Eram duas tias com salário e uma tia que cuidava de todas as coisas da casa: assim se formou a casa das tias, onde sempre havia comida no almoço e no jantar para quem chegasse; onde eu e minhas irmãs passávamos as férias; onde minhas irmãs vieram morar para estudar em São Paulo; onde nossas filhas e filhos eram cuidados quando não estavam na escola; onde minha mãe foi cuidada nos momentos finais da doença; onde a sala tinha espaço para acolher as festas de família.

Nessa casa minhas tias construíram a segurança afetiva e alimentar de três gerações: a delas, a nossa e a de nossos filhos. E ainda nos emprestavam dinheiro para chegar ao final do mês ou para comprar coisas grandes, que seria impossíveis de outra maneira. A gente pagava como podia e no dia do nosso aniversário elas perdoavam as dívidas do ano anterior. Nós tínhamos o nosso jubileu doméstico.

Se não fosse toda essa estrutura familiar não sei como eu estaria lutando para desmantelar a família patriarcal. A Cristina Carrasco (2003) diz que as lógicas e os tempos da economia capitalista são contraditórios às lógicas e aos tempos da vida e que as mulheres terminam por ser a variável de ajuste entre essas lógicas irreconciliáveis. As mulheres remendam tecidos esgarçados desde os tempos de Penélope. Mas como é que a gente desmonta as lógicas e tempos capitalistas ainda vivendo neles e sendo responsável por outras pessoas? Comigo foi com a casa das tias. Tias que eram trabalhadoras assalariadas ou não e que remendavam a meia no ovo de madeira, inclusive as minhas (NOBRE, 2019, p. 140-141).

A tia, especialmente solteira e sem filhos, tem aparecido em inúmeros relatos como a pessoa que pode se dedicar à comunidade, tanto nos cuidados quanto no empenho de recursos financeiros. Sandra Silva, em Magia Negra, apresenta outra dessas mulheres negras, tias, essenciais à sua comunidade.

Do alto dos meus 9 anos, eu já tinha ouvido uma história de que a tia Lurdinha, irmã caçula da minha vó, tinha ganhado muito dinheiro na loteria, possuído muitas casas e carros e ajudado muita gente. Como, então, ela morava naquela casinha velha de madeira na beira da linha do trem, do lado da favela? Meus pais, que não tinham dinheiro para nada, dividiam os nossos poucos recursos com ela. Eu não entendia nada, mas não importava. O que importava era a delícia de passar dias a fio de férias ali naquela casa cheia de primos, de amigos e de música. A casa de dois quartos, sala e cozinha tinha uns 12 moradores fixos e um sem-número de agregados. Era incrível: sempre havia lugar para quem ficava, pelo chão que fosse. E todo mundo queria ficar. Tudo era escasso, menos o acolhimento. Costumávamos dormir com a tia Lurdinha: eu e mais duas primas crianças, em uma cama de casal ao lado da qual havia a escultura 
de uma santa, quase do meu tamanho, de pele preta e vestida com um manto azul de detalhes em branco (SILVA, S., 2019, p. 151).

O cuidado de si, para muitas dessas mulheres, é também ampliado como cuidado do outro. Na proposta de Sueli Carneiro, que parte da premissa de que os discursos e práticas em torno da racialidade comportam uma moral ou uma ética, e que as normalizações constituem um código de conduta explícito ou implícito do qual derivam os estereótipos associados aos negros, de que:

o cuidado de si não se trata apenas da construção de uma subjetividade centrada na adesão livre a um estilo que quer dar à sua própria existência, mas, sobretudo, por voltar-se à construção de sujeitos coletivos libertos dos processos de subjugação e subalternização (...) O cuidado de si se realiza para esses sujeitos no cuidado do outro, cuja libertação é a estética de suas existências (CARNEIRO, S., 2005, p. 303).

Jurema Werneck, ao tratar da luta pela emancipação da mulher negra, afirma que o propósito não é apenas formar mulheres seguras, capazes e brilhantes, que visem com isso adquirir privilégios individuais. Tais conquistas são como veículos para gerar transformações na vida de toda a população negra.

Ainda na primeira metade do século XX, em 1949, Maria de Lurdes Valle Nascimento, se dedicava à organização política das mulheres negras e escrevia a respeito, em sua coluna no jornal Quilombo:

\footnotetext{
Merecem toda atenção as resoluções votadas em maio último pelas mulheres do Brasil inteiro que aqui se reuniram em congresso nacional. Todos os itens abordados pelas congressistas são de importância básica para a existência, a felicidade e o progresso da mulher e, consequentemente, do povo brasileiro da qual ela é mãe dedicada e sacrificada. Portanto a iniciativa da realização desse conclave só poderia merecer elogios e apoio às suas conclusões que, queira Deus, possam em breve se tornar realidade.

Dentre as importantes resoluções tomadas queremos nos referir àquela que trata da regulamentação do trabalho doméstico (NASCIMENTO, M., 2019, p. 35).
}

Como se sabe, apenas em 2013 foi aprovada a chamada PEC das domésticas, a emenda constitucional n ${ }^{o}$ 72/2013, que alterou o artigo $7^{\circ}$ da Constituição Federal, dos direitos dos trabalhadores urbanos e rurais. Foi incluído o parágrafo único: 
previstos nos incisos IV, VI, VII, VIII, X, XIII, XV, XVI, XVII, XVIII, XIX, XXI, XXII, XXIV, XXVI, XXX, XXXI e XXXIII e, atendidas as condições estabelecidas em lei e observada a simplificação do cumprimento das obrigações tributárias, principais e acessórias, decorrentes da relação de trabalho e suas peculiaridades, os previstos nos incisos I, II, III, IX, XII, XXV e XXVIII, bem como a sua integração à previdência social.

Apesar da aprovação, que passou a garantir,no papel, salário mínimo nacional, seguro desemprego, irredutibilidade salarial, $13^{\circ}$ salário, proteção salarial, limitação diária e semanal de jornada, repouso semanal remunerado, horas extras remuneradas, férias anuais, licença gestante, licença paternidade, aviso prévio proporcional, aplicação de acordos ou convenções coletivas, FGTS, tais direitos só foram regulamentados em 2015. E ainda em 2020, sem fiscalização e em um contexto social autoritário, conservador e colonialista, a lei não tem sido cumprida.

O primeiro sujeito coletivo a demandar direitos a empregadas domésticas foi a associação criada por Laudelina do Campos Mello, em 1936, na cidade de Santos, litoral de São Paulo. Laudelina, contou essa história à jornalista Maria Dutra Lima no depoimento publicado em Vozes Insurgentes de Mulheres Negras.

A primeira associação fundada por mim foi em Santos, em 1936, onde nós fazíamos... nós tínhamos um grupo político chamado Frente Negra, e dentro desse grupo político havia várias entidades que funcionavam. E dentro desses grupos, então, tinha um grupo que era dirigido por um professor chamado Geraldo Campos de Oliveira, ele era do Partido Libertador, esse partido foi extinto. Nessa ocasião, fizemos vários movimentos dentro do programa político, programa social e cultural. A gente estava procurando nessa época fazer um movimento cultural dentro do país, para que a raça negra tivesse mais oportunidade de expandir. Durante o ano de 34, 35, nós fizemos um movimento político, para fundação desse grupo político, e dentro do grupo político, nós expandimos vários departamentos.

Então, foi quando veio a ideia da fundação de uma associação para empregadas domésticas. O professor Geraldo de Campos Oliveira era presidente do Clube Cultural Recreativo do Negro em São Paulo, então lá foi fundada a Associação de Empregadas Domésticas. Logo em seguida, então, nos reunimos em Santos e foi fundada a Associação de Empregadas Domésticas. A de São Paulo não continuou, então fiquei só eu em Santos, de 36 a 39. Quando foi 39 começou a fomentação da guerra; quando foi 1940, o Brasil declarou guerra contra o Eixo. Aí foi quando [foram] fechados os sindicatos, e a Associação também. Fechou, paralisou tudo, você não podia ficar conversando na esquina duas pessoas juntas, que a polícia vinha e te levava, era comunista.

Então, ficamos de 40 a 45 sem poder fazer movimento, durante a época da guerra. Em 41 foi feito o alistamento voluntário para as mulheres, porque os soldados seguiram para a Itália e nós ficamos então fazendo o trabalho dos soldados. Então eu fiz quatro cursos: fiz sentinela avançada; e o 
trabalho do blackout que era noite que a gente fazia o trabalho na praia, na entrada da barra, guardando os vários que saiam e entravam.

A guerra terminou em 45 , veio novamente a anistia, e todos os partidos foram reconhecidos, inclusive o Partido Comunista, porque foi a Rússia quem conseguiu liquidar aquela coisa toda. Aí reabriu novamente a Associação, de 45 a 49 eu fiquei em Santos dirigindo como presidente (MELLO, 2019, p. 42-43).

Laudelina de Campos Mello narra, em primeira pessoa, a história coletiva da organização das empregadas domésticas no Brasil. A escrita de si como a escrita da organização política de sujeitos coletivos aparece também no texto de Vanessa Nascimento, Deixa eu lutar, “que é pro mundo ficar Odara”:

Há 9 anos dedico parte de minha vida a um movimento onde as pessoas unem forças para proporcionar experiências de reconhecimento e reencontro de negros e negras com suas raízes. Tenho a convicção de que nossa atuação contribuiu para transformação da vida de milhares de pessoas que buscaram, com dignidade, ocupar espaços historicamente negados à população empobrecida, em especial aos negros. Tenho a certeza também de que há muito a se fazer, pois as mulheres negras ainda não estão dando aulas nas universidades, não estão apresentando programas ou jornais em horário nobres; não estão, enfim, nos espaços de poder. É por elas e por minha filha Odara que continuo lutando (NASCIMENTO, V., 2019, p. 171).

A atuação política de mulheres negras na organização de sujeitos coletivos se dá em agrupamentos declaradamente políticos, como a Uneafro de que Vanessa Nascimento faz parte, como em grupos de cultura que aparecem nos textos de Alessandra Ribeiro, Carmen Faustino e Luana Vieira:

Foi por meio do jongo que me tornei uma referência pública. Foi nele em que fui escolhida como liderança e mestre da comunidade. Foi no jongo que nasceram os primeiros passos de consciência de que eu devo fazer para além de mim e de meus desejos pessoais; foi e é no jongo que olho o mundo e tento contribuir com ele, para que este melhore para todos. São nas rodas de jongo que a ancestralidade me prepara para defender, recuperar e dar novos sentidos diários à Casa de Cultura Fazenda Roseira como espaço de cultura, de reza, de jongo, de encontros entre diferentes e que me ensina a respeitar isso como uma oportunidade de aprendizado um espaço, enfim, de patrimônio de referência para a nossa nação. Terra de preto... Terra de ancestrais de matriz africana e de muito amor compartilhado entre todos que naquele chão pisam, vivem e se inspiram. Como diz a música de Almir Guineto, "Dança do Caxambu: "Saravá Jongo, Saravá" (RIBEIRO, A., 2019, p. 23-24). 
A caminhada poética e das redes de produções literárias se fortalece desde meados de 2009, no bar e no encontro com outras mulheres negras iguais a mim, mães, filhas, estudantes, profissionais, amantes e amigas que enfrentavam o microfone do sarau e clamavam por respeito com seus incômodos textos e manifestos. Surgia, então, um forte movimento de mulheres negras escritoras nas periferias de São Paulo e eu tenho orgulho em olhar para esse espelho e reconhecer meu movimento junto a elas. Aquilombadas, nós frequentamos saraus, organizamos livros, criamos redes de poesia, arte e cura; nós rimos, choramos e desenvolvemos ações em parcerias. Acreditem, pequenas revoluções acontecem na zona sul de São Paulo! (FAUSTINO, 2019, p. 37).

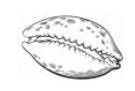

Passei, então, a observar o que faltava ao nosso redor ao invés de dar tanta importância ao que nos excluía. A ideia de fazer parte da construção de uma Comunidade de Roda de Samba como O Pagode na Disciplina trouxe uma reflexão de como poderia analisar o modo de vida de uma juventude negra, sobretudo periférica, a forma como essa juventude vem sendo tratada na perspectiva musical e sambista, sendo protagonista da própria história e, ao mesmo tempo, matéria-prima de trabalho no cenário do samba. O intuito do trabalho da comunidade é constituir forças de existência e resistência de uma manifestação cultural que sobrevive até os dias de hoje e fazer os jovens entenderem qual a importância da valorização do samba enquanto comunidade negra. Este é o reconhecimento mais grandioso dos nossos: reconhecer e entender as teorias das nossas raízes e que elas estão associadas às grandes organizações e às rodas de samba originadas de Aldeias Africanas, onde povos se reuniam em círculos para cantar e dançar, cada um mostrando sua habilidade e conhecimento. Acredito que essa organização é o verdadeiro progenitor musical do samba e que essa fonte de influência foi uma herança deixada a nós. (VIEIRA, L., 2019, p. 92).

\section{Crítica aos processos de exclusão racial, social e de gênero}

Assim, quando destacamos que branquitude é território do silêncio, da negação, da interdição, da neutralidade, do medo e do privilégio, entre outros, enfatizamos que se trata de uma dimensão ideológica, no sentido mais pleno da ideologia: com sangue, ícones e calor (BENTO, C., 2019, p. 208)

Racialidade, para Sueli Carneiro, diz respeito às relações raciais que, no Brasil, são polarizadas por negros em uma ponta e brancos em outra. Mas, quando falamos o termo raça, é praticamente óbvio que estamos nos referindo a pessoas negras, como se brancos não fossem atravessados também por uma condição racial. O Outro, o negro, tem raça. O Ser, o branco, é humano.

Cida Bento estuda a branquitude há décadas e mostra como brancas e brancos, apesar do silêncio e da negação de pertencerem a uma categoria racial, se beneficiam de 
estruturas racistas. Isso não quer dizer que todo sujeito branco é racista, mas que todo branco, em uma sociedade racista, se beneficia do racismo. O reconhecimento e a crítica à branquitude são essenciais para se opor aos processos de exclusão racial.

As desigualdades brasileiras, constituídas historicamente a partir de hierarquias nas relações de gênero, raça e classe, são bastantes visíveis nas vidas de quem ocupa a base da pirâmide social brasileira, as mulheres negras, e no que essas mulheres contam sobre as próprias vidas.

Benedita da Silva, quando era senadora pelo estado do Rio de Janeiro, em pronunciamento no Congresso em 21 de março de 1995, no Dia Internacional de Luta pela Eliminação da Discriminação Racial, colocou:

Sr. Presidente, Srs. Senadores, somos um País muito endividado, e não só de dívidas financeiras. O Brasil está em dívida com o seu próprio povo. Temos muitas contas a pagar na área social, no campo das relações raciais e na esfera cultural. (...) Em todas as fases de nossa história - colonial, monárquica e republicana -, o crescimento econômico do País nunca beneficiou a maioria da população, que se tornava cada vez mais pobre. Nas crises econômicas, socializavam-se os prejuízos; nos períodos de desenvolvimento, privatizavam-se os lucros.

(...)

O Brasil precisa saldar uma dívida histórica que tem causado muita dor a parte expressiva do povo. Estou falando da dívida racial que, ainda hoje, causa sofrimento e frustração a milhões de brasileiros. Quanto à suposta democracia racial, esta só existe mesmo no discurso oficial e livros escolares. A democracia racial é uma ideologia criada para dissimular o racismo que existe na realidade, por meio da falsificação, omissão, folclorização e mitificação da história das populações afrobrasileiras e também da diminuição de seu peso específico na sociedade (SILVA, B., 2019, p. 122-123).

Considerar um discurso parlamentar como escrita de si tem como base a afirmação da pluralidade de mulheres negras, tanto nos lugares em que ocupam/ podem ocupar na sociedade brasileira, quanto nos lugares em que podem estar mais presentes. Na atual legislatura, o Brasil elegeu apenas $4 \%$ de parlamentares negros, somando homens e mulheres negras - 54\% da população. Do total de mulheres - negras, brancas e indígenas elas são $15 \%$ das deputadas e senadores. Mulheres negras ${ }^{9}$ são, 25,38\% da população brasileira, ocupam 2\% das vagas no Congresso: 13 no total, 12 na Câmara e 1 no Senado. Hoje deputada federal, senadora à época do discurso citado acima, Benedita da Silva

\footnotetext{
9 Dados sistematizados pelo jornal Correio Braziliense, na reportagem disponível em: <https://www.correiobraziliense.com.br/app/noticia/politica/2018/10/20/interna_politica,713916/subrepresent ada-bancada-de-mulheres-negras-crescera-30-em-2019.shtml>
} 
costuma denunciar os processos de exclusão racial, social e de gênero de que mulheres negras são vítimas.

No ato de fundação do MNU, em 7 de julho de 1978, nas escadarias do Teatro Municipal, em São Paulo, havia muitas mulheres presentes, mas apenas uma pegou o microfone. Neusa Maria Pereira foi a única a se pronunciar, utilizando como base o texto que havia publicado no ano anterior no jornal Versus, cujo fragmento é agora apresentado:

A mulher negra pertence a uma das minorias raciais mais cruelmente vitimada pelos castigos da divisão da sociedade em classes. Essa divisão é a maior responsável pela campanha de difamação sofrida pela mulher negra, considerada pelos representantes dessa sociedade de classes como objeto sexual e de consumo fácil. Há muito que nós, afrobrasileiros, estamos lutando para apagar esta mancha original e sair do lugar em que nos colocaram.

$\mathrm{Na}$ época da escravidão, estes "dignos senhores" enfiaram suas escravas na casa grande, local onde elas faziam todo tipo de serviços para suas inúteis esposas e ainda serviam de vacas leiteiras para seus filhos.

Estes mesmos "ilustres" senhores também resolveram repartir a cama com as escravas, sendo elas obrigadas a curvar-se ante sua indignidade, seu sarcasmo e sevícias. Nestes momentos, estes senhores esqueciam-se que as negras "cheiravam mal", conforme suas próprias opiniões, e deixavamse dominar por seus desejos. Dessa dominação recebemos como herança a marca de eternas prostitutas. Herança que nos ensinou a temer nossa beleza, nosso corpo e a própria condição de mulher.

(...)

A luta é companheira da mulher negra, sempre, desde seu nascimento. Nos tempos pós-abolição, quando os negros foram soltos no mundo sem eira nem beira, com seus serviços substituídos pelo do imigrante, ela manteve a dignidade da família, trabalhando nos fogões das tradicionais famílias brancas. Ela ajudou seu homem a salvar seu caráter.

Hoje, quando a crise de desemprego atinge também a nós, negros, ainda é ela que segura o lado mais pesado do barco. Pois, quando uma falta, o outro não pode falhar. Os filhos necessitam do leite e seu grito de fome machuca muito mais do que a chibata dos "senhores" machucava a pele dos nossos antepassados. Por isso, ela enfrenta o trabalho coletivo e obscuro nas fábricas, nos campos e nas repartições públicas, hospitais e escolas mesmo nas posições mais inferiores. Depois ainda vai para a sua maloca cuidar de tudo, dos filhos, fazer comida, lavar roupa (PEREIA, 2019, p. 65-67).

Também nas letras de samba, gênero expressivo de mulheres negras compositoras desde que Dona Ivone Lara começou a assinar as próprias letras, em vez de pedir que o primo continuasse assinando, a denúncia aos processos de exclusão é colocada. Leci Brandão, a primeira mulher a fazer parte da Ala de Compositores da Mangueira o faz em inúmeras letras, como em Maria, de 1977, que faz um paralelo entre mulheres negras/suburbanas e mulheres brancas/ da cidade: 
Maria da cidade anda bem vestida

Maria do subúrbio não sabe de moda

Maria da cidade vive a boa vida

Maria do subúrbio faz da vida a roda

Maria da cidade tem boa empregada

Maria do subúrbio tem que se empregar

Lavando, cozinhando e arrumando a mesa

Pois dinheiro da despesa tem que se poupar (BRANDÃO, 2019, p. 69)

Em inúmeros fragmentos de textos táticos, tanto os escritos para o livro quanto os produzidos na oficina de escrita, o processo de exclusão racial, social e de gênero de mulheres negras está registrado. Seria possível destacar páginas e páginas dessa constatação da realidade brasileira quando mulheres negras escrevem sobre si mesmas. Enquanto sujeitos não racializados costumam falar de si sem nenhuma necessidade de mostrar as condições sociais para que sua vida se desenrolasse de determinada maneira, para mulheres negras contextualizar suas vivências a partir de uma explicação do lugar social ocupado por este sujeito político parece essencial. Escritoras negras famosas, como Carolina Maria de Jesus, Conceição Evaristo, Ana Maria Gonçalves, Cidinha da Silva, dentre tantas outras, assim o fazem.

Destaco alguns fragmentos, que mostram a diversidade de críticas apresentadas. Cleo Dias mostra como a falta de acesso a terras - que se impôs a pessoas negras no Brasil como dificuldade extrema desde 1850, já explicitado anteriormente, tem conexão com sua própria história de vida. Maria de Jesus Pereira Santana e Luciana Reis, em um contexto urbano, também mencionam a falta de terra/ moradia como um marco importante na trajetória de suas vidas e famílias. Ariane Cor, ao apresentar seu projeto Minas Programam, traça um panorama da exclusão de mulheres negras do mercado de trabalho, especialmente na área de tecnologias digitais.

(...) Nasci em Adamantina-SP, onde meus pais moravam em um sítio como meeiros: uma forma de exploração de pessoas que não tinham recursos nem um pedaço de terra para plantar e, por isso, trabalhavam para o fazendeiro quase de graça (DIAS, 2019, p. 49)

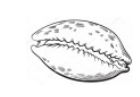

Moradia, outra grande dificuldade. Minha mãe perdeu o barraco, construído em um terreno adquirido com sacrifícios, pois ela foi ludibriada pela proprietária, que a convenceu a devolver o lote em troca de um quarto e uma cozinha, sem custos, até a maioridade de meu irmão mais velho. Esse acordo foi quebrado dois anos depois e, nossa família, ao 
relento, passou a morar em vários locais oferecidos em troca de trabalhos extras de minha mãe. Eram locais terríveis, sem banheiro, onde chovia dentro, não havia condições de preparo de alimentos, com fogão a carvão e "chuva interna abundante". Quando melhorou um pouco a situação, minha mãe penhorou seu único bem, um rádio, para conseguir o valor do depósito em uma moradia melhor: um quarto de tijolos, em um quintal com mais de cinco famílias, um único banheiro, um único tanque para lavar as roupas e com água do poço a ser retirada a 27 metros de profundidade (SANTANA, M., 2019, p. 124-125).

As coisas ficaram mais difíceis e perdemos a casa que meus avós deixaram para os filhos e netos morarem. Mais uma vez a injustiça prevaleceu, sem que tivéssemos defesa, mesmo pagando advogados e utilizando a lei de Usucapião. Gastamos tudo que tínhamos para pagar os honorários advocatícios, mas não teve jeito: fomos despejados, com caminhões da prefeitura e a polícia militar vindo nos tirar. Contraditória nossa justiça, pois quando minha mãe e tia precisavam da polícia, esta não aparecia empenhada em ajudá-las; porém, para nos jogar na rua, ela apareceu rapidamente. Parecia que tínhamos ocupado o terreno e o sacrifício dos meus avós de pagar anos a fio o terreno foi todo para o ralo. Ainda bem que eles não estavam mais nesse plano, pois com certeza eles se reviraram no caixão. Foi um choque para minha mãe e tia, já que perdemos tudo que tínhamos e nossos móveis ficaram um lixo. Com apenas duzentos reais no bolso aluguei uma casa para não ficarmos na rua e, depois disso, a saúde mental da minha mãe nunca mais foi a mesma. Desse episódio para frente, além de sustentar meu filho, agora tinha que assumir o cuidado da minha mãe, o que continua até os dias de hoje (REIS, L., 2019, p. 113).

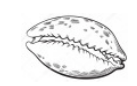

Desde que o curso Minas Programam foi criado, nosso discurso apresentou a importância de incluir mais garotas e mulheres na tecnologia, principalmente as garotas negras e periféricas, que são as que estão mais afastadas dessas áreas, o que as coloca em uma espiral multidimensional decrescente de desigualdades nas sociedades contemporâneas. As mulheres que estão mais ausentes dos espaços de trabalho, pesquisa e negócios em tecnologia não são uma fatia em um gráfico de pizza. Elas têm nome, cor de pele, moram em lugares específicos e, muitas vezes, realizam o trabalho de cuidado e o trabalho doméstico para que os outros integrantes de suas famílias possam trabalhar, tendo pouco tempo para os estudos em razão do lugar onde moram e da infraestrutura local (COR, 2019, p. 28).

Dalva Santos, ao narrar como sua história destoa das demais, também escancara, por oposição, a situação de exclusão vivenciada pela maior parte das mulheres negras. Lívia Milena mostra como a mãe, desde muito cedo, foi privada de sua própria vida para, como empregada doméstica, garantir a reprodução da vida de pessoas brancas; e que só na chegada à universidade, graças ao papel fundamental de uma professora negra, pode 
perceber como acontecimentos de sua vida podiam ser compreendidos de uma perspectiva social mais ampla. Maria de Jesus Santana narra seu ingresso no trabalho doméstico e conta das tensões do processo de escolarização.

Sou a exceção, a cota antes mesmo que ela existisse, a única negra da turma. Estou em um lugar de privilégios. Tive uma excelente educação de base, fui aprovada em duas universidades públicas, conquistei um diploma de mestrado e sempre estive em cargos de destaque. Tal condição, apesar de ser muito relevante para a branquitude, não me faz exatamente melhor, mas é um lugar que parece cumprir a profecia astrológica, um lugar que me faz ser como um pêndulo que oscila entre a força e a solidão (SANTOS, D., 2019, p. 53).

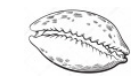

Minha avó e meu avô trabalhavam na lavoura, então era a minha mãe, desde muito nova, que ficava responsável pela casa, pela alimentação e pelo cuidado dos irmãos. Ela saiu da casa dos meus avós por volta dos 13 anos para trabalhar como empregada doméstica. Assim, já podia ajudar os pais com dinheiro. Quanto ao estudo, nenhuma de suas patroas e patrões a incentivaram, mas lhe diziam que ela fazia parte da família (SILVA, Lívia, 2019, p. 75).

Este foi, sem dúvidas, um divisor de águas em minha vida. A primeira da família a ingressar no ensino superior. Tive muitas dificuldades em acompanhar as aulas nos primeiros semestres. A Professora Priscila Beralda fez muita, mas muita diferença mesmo em minha formação e em minha vida como um todo, pois era uma mulher negra que pautava a questão racial em suas aulas. Acreditem: isso é raro no curso de Serviço Social, baseado no pensamento marxista que, sem dúvidas, tem a sua importância; no entanto, não é suficiente para explicar a realidade brasileira que se construiu com base na escravidão - como pontuava tão bem a professora Priscila. Com ela, entendi a necessidade de termos cotas raciais, uma política que não existia porque nós, negros, somos incapazes. Estudando para um seminário solicitado por ela sobre a ideologia do branqueamento no Brasil, entendi por que eu alisava o meu cabelo e aceitava ser chamada de morena e porque os meus tios, todos negros retintos, disputavam quem era mais claro, por que a minha tia, negra retinta, dizer que nunca ia namorar um homem negro, que de negra bastava ela, por que a minha prima, Yasmim, fruto de uma relação afrocentrada, dizer, aos cinco anos que, quando crescer, será loira, igual a mulher da televisão. Entendi ainda que a minha família não era pobre por falta de sorte, tampouco não estudaram por falta de esforços. E assim seguia apaixonada pelo conhecimento, que me tirou a venda dos olhos, que me mostrou que o conhecimento liberta. À medida que entendia a realidade do povo negro brasileiro, eu entendia a minha e a da minha família (SILVA, Lívia, 2019, p. 82-83) 
Comecei minha vida profissional aos 5 anos de idade como babá do pequeno Luiz Henrique. Vocês podem pensar: como, com essa idade, alguém poderia ser uma babá? Eu tinha responsabilidades: cuidar para que o pequeno ficasse no berço ou "chiqueirinho" sem engasgar, sendo distraído para não chorar e alimentado com papinhas. Apesar de criança, eu não podia dormir, ou brincar, como qualquer outra criança da idade.

(...)

Minha vida escolar foi marcada por dificuldades. Comecei apenas aos 8 anos de idade, pois não havia escolas para todas as crianças. Mais tarde, após terminar o primário, não consegui entrar no ginásio e, pelo mesmo motivo, tive que cursar um quinto ano chamado "admissão", um curso de português e matemática. Não tendo condições para comprar materiais escolares para os dois filhos, a prioridade de minha mãe era o filho maior, menino e provável provedor da família, já que a lógica seria a menina se preparar para ser uma ótima dona de casa, casar e cuidar de marido e filhos. O máximo que eu conseguia era utilizar os mesmos materiais de meu irmão, como estojo de madeira, lápis, borracha e régua. Ele os utilizava pela manhã e eu à tarde. Eu ficava na porta da escola aguardando a saída dele para pegar o estojo. Meu uniforme, uma saia azul marinho e camiseta branca, era confeccionado por minha mãe. Eu usava uma saia de pano de saco de farinha de trigo, tingido de azul.

(...)

O ginásio foi cursado à noite, apesar de não ter os 14 anos completos, exigidos para o curso noturno. Com problemas de saúde, minha mãe sofreu várias cirurgias e, com 12 anos, eu já trabalhava como doméstica para ajudar nas despesas da casa, mesmo possuindo o curso de datilografia, na época um dos diferenciais para conseguir emprego em escritório. Trabalhei como auxiliar de costureira e ajudei a vizinhança a tirar água dos poços para as donas de casa. Meu primeiro emprego com registro em carteira foi em uma indústria de viés e etiqueta, já com 17 anos. Em seguida, trabalhei em um banco e em vários escritórios como trabalhadora temporária, até ingressar na faculdade de Economia. Prestei, então, um concurso público como escriturária e pela classificação fui trabalhar na Coordenadoria. Eu era uma das três secretárias que compunham o departamento; ainda assim, tive que pedir empréstimo educativo no banco Caixa, cujo pagamento começou um ano após terminar o curso e, assim, consegui sair das inúmeras dificuldades. Sem recursos para alimentação, estando faminta nas aulas e tendo o transporte dificultado pela distância e custo, consegui, a partir do segundo ano, um percentual de bolsa no primeiro e no segundo semestre pelo meu desempenho e, com o reconhecimento do professor e vice-reitor da faculdade, fui indicada como monitora de ensino. A viagem de trem para a faculdade não era nada confortável, e ainda ia com fome, pois a marmita do almoço à tarde já tinha sido superada. A divisão de lanchinhos nem era, muitas vezes, possível entre os colegas, mas desde o primário nunca levava lanches - foram poucas as vezes em que isso aconteceu (SANTANA, M., 2019, p. 123-124).

Maitê Freitas mostra como a percepção das discriminações de raça, classe e gênero se manifestavam no seu cotidiano, no mundo do trabalho, até decidir romper com aquilo que a expunha a tais situações. Situação semelhante à narrada por Silvana Bahia. 
Durante muito tempo optei por inverter a lógica da discriminação. Sabia que muitas situações no trabalho estavam relacionadas ao fato de eu ser pobre e ser negra. Às vezes, eu pensava "me tratam assim, porque sabem que eu sou do Grajaú. Sou pobre, sou preta". Romper com essa hierarquia discriminatória foi uma construção por uma nova forma de me entender, de me posicionar e de construir o meu discurso no meio em que frequentava. Com o tempo entendi que não importava: eu poderia ser rica, milionária, mas eu sempre seria vista como aquela que serve o café para os brancos e não como aquela que tem articulação e poder de fala.

(...)

Em uma sociedade racista, tentam me fazer acreditar que o sonhar e o viver o sonho são um privilégio e que, a mim, mulher negra, caberia zelar para que eles - os brancos - alcancem seus "sonhos" com casa limpa, roupa lavada e comida feita (FREITAS, 2019, p. 120).

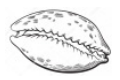

Já no final da graduação eu ainda não tinha conseguido um trabalho bacana na área e já tinha feito muitos processos seletivos. Passava nas provas, mas sempre ficava nas entrevistas e morria de culpa, porque pensava: "minha mãe investiu tanto em mim e não vou conseguir ser jornalista". Minha crise com o jornalismo começou nesse momento e entendi que não tinha o perfil de "jornalista" que o mercado queria. Entendi a partir da fala da coordenadora do curso que disse que eu era muito colorida e que meu cabelo era muito "assim" para arrumar trabalho. E olha que tentei me enquadrar muitas vezes no perfil "corporativão" e hoje agradeço por não ter ficado em nenhum desses trabalhos porque sei lá quem eu teria me tornado. Durante muito tempo sofri pensando o que ia fazer com o que aprendi na universidade, já que não me encaixava em lugar algum (BAHIA, 2019, p. 159-160).

As marcas da escravização negra seguem presentes nos relatos contemporâneos. Seja nas reflexões sobre o nome do colonizador feita por Marli Freitas, e a pouca possibilidade de saber suas origens ancestrais, seja nas histórias contadas no Recôncavo, aqui reproduzidas a partir da narrativa de Nega Duda.

Sou Marli de Fátima Aguiar. Os dois primeiros nomes, meus pais escolheram, já o terceiro veio do colonizador. Do dono da fazenda onde habitaram meus primeiros ancestrais vindos de África, e, como este nome foi dado após a "abolição", foi passado de geração a geração. No dia em que obtive esta informação, tentei rejeitá-lo, negá-lo, mas não foi possível. Pensei: "carrego o sobrenome e as marcas, na história, na minha vida e na de meus pais". Gostaria de ter tido um nome em iorubá, ou igbo, choça, zulu... Mas não pude mudá-lo, porque a distância das minhas raízes africanas também é uma marca colonizadora e destruidora de corpos, de línguas, nomes, ideias, sonhos e histórias (AGUIAR, M., 2019, p. 127).

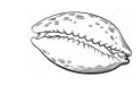

Meu sonho é montar meu restaurante e botar o nome da minha mãe nele: Dete do Xangó. Ela se autodeclarava "a barona de Cajaíba", porque 
Cajaíba é uma ilha maravilhosa da minha cidade. Foi uma ilha do Barão Fernão Rodrigues Castelo Branco desde o tempo do império, mas também foi uma ilha amaldiçoada, onde se matava mais negros no Recôncavo. Até hoje existem os fossos cheios de lanças onde o Barão jogava seus escravos vivos. A maré enchia e levava esses corpos para o mar. Como sempre, a água salgada, o mar, levando, lavando e curando nossos corpos (DUDA, 2019, p. 149).

\section{Ruptura com a subordinação e a subalternização}

A imagem de uma neguinha atrevida, que interrompe a festa dos brancos ao falarem sobre os negros, utilizada por Lélia Gonzalez na abertura do texto clássico Racismo e sexismo na cultura brasileira, condensa aquilo que chamo aqui como ruptura com a subordinação e a subalternização.

Os muitos fragmentos que podem ilustrar esse processo a que chegam determinadas mulheres negras, nas práticas de resistência pelo cuidado de si e cuidado do outro - na ação política coletiva, tratam das rupturas com processos excludentes que se apresentam nos mais variados formatos.

O prazer proporcionado em rodas de mulheres negras com a leitura deste fragmento de Lélia é algo que escapa às descrições possíveis, mas se manifesta em risos, olhares cúmplices, sentimento de vingança exalado no burburinho que cresce no ambiente.

Foi aí que a neguinha que tava sentada com a gente, deu uma de atrevida. Tinham chamado ela prá responder uma pergunta. Ela se levantou, foi lá na mesa prá falar no microfone e começou a reclamar por causa de certas coisas que tavam acontecendo na festa. Tava armada a quizumba. A negrada parecia que tava esperando por isso prá bagunçar tudo. E era um tal de falar alto, gritar, vaiar, que nem dava prá ouvir discurso nenhum. Tá na cara que os brancos ficaram brancos de raiva e com razão. Tinham chamado a gente prá festa de um livro que falava da gente e a gente se comportava daquele jeito, catimbando a discurseira deles. Onde já se viu? Se eles sabiam da gente mais do que a gente mesmo? Se tavam ali, na maior boa vontade, ensinando uma porção de coisa prá gente da gente? Teve uma hora que não deu prá aguentar aquela zoada toda da negrada ignorante e mal educada. Era demais (GONZALEZ, 2019, p. 74).

Cabe ressaltar o sentido coletivo dado por Sueli Carneiro às práticas de desconstituição dos saberes e formas de assujeitamento impostas pelo dispositivo de racialidade e pelo epistemicídio. É da ampliação do cuidado de si para cuidado dos outros que se constitui uma estética da existência que tem o sentido na vida na ação por emancipação coletiva da racialidade sujeitada (CARNEIRO, S., 2005, p. 324). Lélia 
Gonzalez, segundo reconhece Sueli Carneiro, provoca ruptura ao positivar aquilo que estigmatizava as mulheres negras, invertendo estereótipos negativos, percebendo a vitalidade e as possibilidades a partir dos traços culturais e corpos estigmatizados.

Cenas específicas vivenciadas e relatadas por mulheres negras permitem captar momentos de ruptura, nas diversas fases das vidas, em variados formatos. Laudelina de Campos Mello conta de um episódio na infância que provavelmente marca depois sua ação insubmissa e insurgente frente ao racismo. A partir das consequências de uma negativa insurgente da mãe de atender aos patrões brancos e poderosos em qualquer dia, qualquer hora, a menina Laudelina também se coloca.

Eles não deixavam minha mãe em paz, mesmo que ela tivesse casada, ela tinha que ir lá atender a sinhazinha, a sinhá e fazer as coisas que elas queriam, né?

Aí, num certo dia, ela tinha um cachaceiro, um português que obedecia muito as ordens dela, então mandou ele ir na minha casa buscar minha mãe pra fazer um serviço pra ela, e minha mãe então saiu para ir atender. Quando chegou num pedaço da rua, minha mãe resolveu não ir e falou: "Ah! Eu não [...]".

Ela mandou prender minha mãe que minha mãe não obedecia às ordens. Minha mãe foi presa. Pela polícia, eles mandavam, né? A escravidão continuava mesma coisa, eles mandavam em tudo, né?, escravo não tinha como viver, como se manter porque foi solto num campo aberto. Aí prenderam minha mãe, e eu fui na delegacia, falei com o policial lá que tinha prendido minha mãe. Ele disse assim: "Ah! Sai daqui negrinha, sai daqui negrinha, senão eu vou bater em você." Eu peguei, fui no juiz - a minha mãe lavava roupa pro juiz - o juiz me expulsou também. Tava fazendo uma construção, tinha um monte de pedra assim na calçada, eu peguei aquela pedra, apedrejei tudo o quanto foi vidro da casa do juiz, acabei com a casa do juiz. Era pedra, pedra... e ele: "Para, para." E eu saí correndo, né? E eu fui pra casa da minha tia, que era minha madrinha. Aí contei pra minha madrinha. Aí ela tomou conhecimento que ele foi tirar minha mãe, foi e tirou (MELLO, 2019, p. 41).

Laudelina rompeu com os processos que a submetiam e liderou ações que beneficiavam coletivamente mulheres negras. Em sua escrita de si, relatada oralmente a uma jornalista, talentosamente conta de episódios centrais e aspectos muito concretos de rupturas com a subordinação, muitas vezes possibilita por alianças com brancos solidários à pauta racial e social das empregadas domésticas.

Foi logo que eu vim pra Campinas, 54, 55, por aí: de manhã, comprava o jornal Correio Popular, tava "precisa-se de uma empregada, prefere-se portuguesa, precisa-se de uma cozinheira de forno e fogão, prefere-se branca". Falei: "eu vou acabar com essa coisa", aí fui lá no Correio e perguntei: "quem é o diretor daquela parte?", e o porteiro lá me disse "é 
Bráulio Mendes Nogueira". Subi no elevador, já saí em frente dele, falei: "Você que é o Bráulio Mendes Nogueira?" - "Sou, em que lhe sirvo?" "vai servir em muita coisa". Falei: "E que história é essa de precisa-se de uma empregada, prefere-se branca; precisa-se de uma empregada, preferese portuguesa?". Aí o Bráulio disse: "É, eles vem pedindo, traz o anúncio já escrito, a gente é obrigada a publicar. Mas quer saber de uma coisa? Vou acabar com esse negócio, a senhora topa a briga?". Falei: "Topo". Dia seguinte, seis horas, comprei o jornal, não tava... "precisa-se de uma empregada", mas não dizia a cor nem a nacionalidade (MELLO, 2019, p. 44-45).

A insubordinação de Carolina Maria de Jesus, não só ao romper com enquadramentos de sua escrita à direita ou à esquerda, se manifesta também na escrita de cenas cotidianas, em frases irônicas que poderiam ser consideradas ingênuas, amparadas por reflexões densas politicamente:

Fui na delegacia e falei com o tenente. Que homem amável! Se eu soubesse que ele era tão amável, eu teria ido na delegacia na primeira intimação. $\mathrm{O}$ tenente interessou-se pela educação dos meus filhos. Disseme que a favela é um ambiente propenso, que as pessoas têm mais possibilidades de delinquir do que tornar-se útil à pátria e ao país. Pensei: se ele sabe disto, por que não faz um relatório e envia para os políticos? O senhor Jânio Quadros, o Kubitschek e o Dr. Adhemar de Barros? Agora falar para mim, que sou uma pobre lixeira. Não posso resolver nem as minhas dificuldades... O Brasil precisa ser dirigido por uma pessoa que já passou fome. A fome também é professora. Quem passa fome aprende a pensar no próximo, e nas crianças (JESUS, 2019, p. 60-61).

O exemplo de outras mulheres, e também as críticas e cobranças recebidas, educaram e educam para as rupturas. Alessandra Ribeiro e Débora Marçal contam das avós e das tias que sempre souberam o que queriam e os caminhos para chegar ao que queriam, mesmo nas condições mais adversas, e assim educaram a elas e outras meninas. No texto de Marli Aguiar aparecem histórias do tempo da resistência à escravização, que aqui interpreto como raiz ancestral para as rupturas atuais.

(...) Ela impressionava com sua generosidade e perspicácia. Quando ela queria algo, o universo também queria sempre. Movia o mundo a sua volta. (...) Para depois e além dela, existem e existiram outras mulheres, como tia Lucília (tia Lu) e sua absoluta resolução em me forçar, sem imaginar nenhuma possibilidade contrária, a fazer e materializar o melhor: seja um copo, seja uma casa. Tia Lu sempre exigia que eu buscasse o melhor em mim. E como foi bom ter essas cobranças.

(...)

Nessa caminhada, me tornei doutora acadêmica. Entendi que essa ferramenta da ciência formal e nada inclusiva, a universidade, era e é fundamental para o projeto de semear esse futuro em igualdades. 
E agora, nesse momento, realizo passos e planto sementes para as próximas gerações. A primeira, com a conclusão da tese, em que desenvolvi uma hipótese conceitual sobre a Matriz Africana e as nossas essências na ciência. É uma contribuição intelectual pautada por milhares de histórias vivenciadas, registradas e compartilhadas por nossos ancestrais pretos e também por brancos que pesquisam e estudam a nossa herança e passaram a se dedicar conosco na busca pela consolidação de um Brasil sem racismo. Um país com chances e oportunidades igualitárias independentemente de raça, gênero, classe social e outros elementos que compõem nossa diversidade humana e nossa sociedade (RIBEIRO, A., 2019, p. 21-24).

Somos uma linhagem de Marias, de mulheres negras comuns, criadas na periferia da zona sul de São Paulo. Eu, Mônica e Sandra, filhas de pais diferentes, somos diferentes fisicamente, mas com muitas coisas parecidas. Carregamos os mesmos ensinamentos, alguns repetidos religiosamente toda vez que saíamos de casa: "cuidado na rua", "não beba bebida no copo de ninguém", "nunca sustente outra pessoa, todo mundo precisa se sustentar", "se algum dia um homem te bater e você não fizer nada, ele vai te bater sempre". Não importa nossa crença, se somos feministas ou evangélicas, esses ensinamentos estão sempre conosco (MARÇAL, 2019, p. 58).

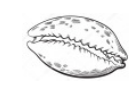

Meu pai sempre trazia uma história ou outra sobre uma personagem em especial, não me lembro o nome, mas sei que passara pela escravidão. $\mathrm{O}$ personagem era escravizado, vivia maus tratos na fazenda, e não queria viver mais aquela situação. Ele fazia várias tentativas de fuga com outros pretos, para fugir das fazendas de café em Minas, dizia meu pai. Essas memórias da escravidão ainda estavam muito perto para ele. Era possível que seu avô, meu bisavô, fora aquela personagem. Para nos tranquilizar e para que dormíssemos bem, terminava a história com final feliz: o escravo conseguia fugir e se encontrar com outros pretos no meio do mato, onde nenhum branco ou capataz conseguiria entrar. Se essas não são histórias de resistências de quilombos, não sei o que são. Então, é muito interessante para mim trazer e rever estas memórias que há tanto tempo ficaram guardadas (AGUIAR, M., 2019, p. 135).

Beth Beli, narra a estruturação da própria vida adulta sem nem mencionar a ruptura com os processos de subordinação e subalternização. A menina preta da Brasilândia, periferia Norte de São Paulo, não precisou passar por empregos ou situações-limite de opressão para romper e a partir daí atuar, de acordo com seu próprio repertório e caminho. Em uma trajetória própria, protagonizada por ela mesma, foi aprofundando seu conhecimento da negritude, de mulheres e referências negras, abrindo possibilidades para si e para outras mulheres, como é o caso do bloco afro Ilú Obá de Min que hoje dirige. 
Aos 19 anos iniciei minha vida profissional como percussionista, tocando com a Banda Lá em 1987, uma das primeiras bandas afro de São Paulo. Essa banda me deu base para meus conhecimentos sobre meus ancestrais, sobre defender os meus e sobre conhecer e reconhecer a história do meu povo preto. Participando ativamente como percussionista, tive as minhas primeiras referências de mulheres negras e conheci as histórias de rainhas, como Nzinga, Dandara, Akotirene, Luiza Mahin, Geledés, Audre Lorde, Raquel Trindade e tantas outras mulheres politicamente corretas e lutadoras (BELI, 2019, p. 31).

$\mathrm{O}$ ato de escrever em si, especialmente em contextos coletivos, é percebido como possibilidade de ruptura e resistência ao racismo, como se pode ler nos fragmentos de Carmen Faustino e Lívia Milena da Silva.

Com mulheres negras produzindo e semeando literaturas por aí, os silêncios são ecoados e ganham força quando soprados aos ouvidos e olhos das outras. As narrativas latentes no corpo negro feminino estão em constante transbordamento e não cabem mais na voz de outros nem nas histórias mal contadas. Eu me sinto acolhida com outras iguais a mim, pois me certifico de que as ideias e experiências podem até nos projetar a caminhos diferentes, mas não afetam nosso poder coletivo e articulado de trocar saberes, boa sorte, poesias e afeto. Eu aprendo sobre mim com mulheres de outras frentes e que vivenciam outras experiências. (...)

Junto às minhas, enfrento corajosamente os momentos de baixa autoestima e insegurança introjetados pelo racismo, escrevo e pratico o exercício diário de olhar meus espelhos, movimentar as palavras e deixálas fora da gaveta. Não apenas os meus textos, mas também toda a produção intelectual negra feminina precisa girar em outros terreiros, ter registro físico e alcançar todas as pessoas. Minha mãe, avós, tias e irmãs precisam ler mulheres negras; a vizinha, a amiga, a professora, a enfermeira podem ler mulheres negras; os doutores, os companheiros, os amantes, os universitários devem ler mulheres negras (FAUSTINO, 2019, p. 38).

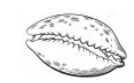

Para finalizar, preciso registrar que foi difícil, por razões diversas, escrever esse texto. Porém, não escrevo apenas por mim. Escrevo por todas as minhas antepassadas. Por todas aquelas que ainda não têm voz. Escrever a nossa história é um ato de rebeldia. E sigo com orgulho dessa mulher que constituo a cada dia, por interferência das que vieram antes de mim e das que estão mudando o mundo agora, assim como eu. Ano que vem completo 30 anos e estou fora das estatísticas que assolam as mulheres negras. Tenho refletido na terapia que isso é resistência (SILVA, Lívia, 2019).

O acesso à educação de qualidade, como formulado por Sueli Carneiro em sua tese, se configura como das principais possibilidade de emancipação dos sujeitos negros, para 
que possam ocupar outros lugares sociais diferentes daqueles reservados a eles pelo dispositivo de racialidade. Estudar e se especializar academicamente é uma forma de resistência assim percebida, que é mencionada em diversos textos, aqui, destacados, os de Dalva Santos e Silvana Bahia. Com maior e melhor escolarização, algumas dessas mulheres têm a oportunidade de se colocar no mercado de trabalho em postos de maior prestígio e remuneração.

Em 2002 entrei na faculdade - Produção Cultural e Filosofia -, numa ousadia enorme de quem se previa uma grande pensadora e, ao mesmo tempo, pretendia atuar pela cultura do nosso país. Já nos primeiros semestres me vi empreendedora, abrindo em sociedade uma produtora cultural. Em pouco tempo expandi a perspectiva empresarial para o debate político e me vi gestora de projetos relevantes voltados à política pública de cultura.

(...)

Em 2013, em Brasília, mais um teste de renascimento e transformação. Lá estava eu, a única negra da equipe, a única negra de um Ministério inteiro. O sentimento de solidão foi devastador, mas novamente algo de potente surgiu. Se eu me via sozinha, faria questão de reafirmar esse lugar: turbantes, pautas pela diversidade, representatividade negra, povos de matriz africana, periferias, territórios. Arenas de pura disputa que eram travadas a cada e-mail, a cada bom dia. Na sequência, o mestrado, a universidade pública, o conceito Capes 6 e a constante lembrança de que pessoas como eu fatalmente sentiram muita dificuldade "com a teoria", mas a academia pouco sabe que a teoria deles bebe na nossa prática. Difícil mesmo não foram os textos, mas ter que me esquivar do preconceito e racismo que estruturalmente nos coloca em xeque a cada passo. Sou mestra. E com orgulho de ter levado para os anais da academia o debate sobre a inteligência periférica. Que é negra. É ancestral. É refinada e sagaz (SANTOS, D., 2019, p. 55-56).

Talvez seja importante dizer que sou a primeira mulher a ter um curso de graduação e de pós-graduação na minha família, algo comum às pessoas da minha geração, pessoas parecidas comigo. Boa parte do que fiz e faço na minha vida tem a ver com as oportunidades de aprender que tive ao longo da vida. E tentando responder à pergunta inicial desse texto, eu não sei aonde o conhecimento e a curiosidade podem nos levar, mas sei que me constroem e contribuem para eu ser quem eu sou, para fazer escolhas que faço e traçar um caminho diferente. Reconheço a importância desses conhecimentos na minha vida e agradeço às minhas ancestrais pelo esforço de me darem a estrutura para trilhar esse caminho (BAHIA, 2019, p. 161).

No texto de Lara Dee, o empreendedorismo aparece como parte importante do processo de ruptura com a pobreza e as discriminações. Primeiro, como possibilidade 
individual, depois, como se verá no tópico seguinte, no empreendedorismo social, como construção de alternativas coletivas para mulheres negras pobres.

Quando eu era criança, minha mãe, que era branca, me dizia que pobres e pretos como eu não tinham direito a nada. Ela tolerava uma vida de miséria e humilhações e aceitava um marido ausente, mas eu não concordava com aquela submissão e resignação. Eu vivia sonhando em ter uma vida melhor e imaginava fazer coisas para isso acontecer. $\mathrm{O}$ que eu sentia já era a vontade de empreender. Eu me incomodava com a pobreza em que vivíamos. O primeiro negócio que imaginei foi montar banheiros pra ninguém ter que ficar na fila esperando a sua vez, porque vivíamos em um cortiço em Itabuna, com muitos quartos e apenas um banheiro. (...)

Foi para mudar de vida que eu vim com minha mãe pra São Paulo e fui trabalhar como empregada doméstica, tendo a sorte de ter como patroa uma francesa que apostou no meu potencial e me colocou na escola pra eu me alfabetizar aos 12 anos. Assim, de assistente de babá, um ano depois eu administrava a agenda pessoal dela, seus compromissos, seu closet e seus horários. Por indicação e providências dela me tornei dançarina do Programa do Chacrinha - eu nem sabia dançar, mas fui aprendendo a ser chacrete e depois fui passista de shows de mulatas. Tornei-me Lara Dee e tive fama, mas, mesmo com tudo o que esse trabalho me proporcionou, sofri muitos preconceitos por ter essa profissão, embora jamais tenha me desanimado. Já sabia que o palco não era o meu caminho, mas foi nele que descobri que a beleza pode ser um instrumento de transformação, decidindo, então, trabalhar com isso de forma positiva para ajudar as minhas iguais. Sem medo algum, tinha que desbravar e quebrar todos os tipos de tabus.

(...)Paralelamente ao trabalho de dançarina, fui montando pequenos negócios, ano após ano. Ao ir ganhando a confiança das minhas colegas de palco, terminei cuidando dos pagamentos dos shows que os empresários comissionavam. As dificuldades das dançarinas me despertaram as oportunidades de negócios. Percebendo que o transporte era um grande problema, que se gastava muito dinheiro com táxi, resolvi mudar isso. Investi em um carro zero km à prestação e acabei virando "a primeira Uber do Brasil" nos fins da década de 1970. Buscava as meninas em suas casas e as levava de volta. Com isso, pagava a prestação do meu carro e ainda me sobrava um dinheirinho.

(...)

Minha experiência em trabalhar na noite fazendo shows ajudou a perceber as necessidades dessa clientela. Observei que as mulheres que trabalhavam na noite, como as dançarinas e as prostitutas, poderiam diminuir a hostilidade contra elas usando roupas diferentes no ir e voltar do trabalho. Assim, criei a grife Delara, que foi meu primeiro projeto de sustentabilidade envolvendo mulheres de comunidade, pois eu só empregava as mulheres do Morro como costureiras e tinha uma modelista da comunidade da Penha, parceira que acreditou em mim e nas minhas ideias, como fazer peças versáteis que, de um lado, eram roupas para serem usadas de dia e, de avesso, viravam roupas para a noite. Durante seis anos mantive essa grife e tivemos uma fábrica em São Cristóvão que chegou a ter quarenta e cinco costureiras em cooperativa de costura, com pronta entrega no Rio de Janeiro, São Paulo, Salvador e Goiânia, o que não seria possível sem as mulheres parceiras da minha rede. Chegamos a atingir todas as meninas que trabalhavam na noite Rio/São Paulo. Foi uma 
febre vestir Delara, mas a economia brasileira atravessava grave crise naquela época: veio o Plano Cruzado e, quando a moda do Rio de Janeiro e suas confecções faliram, fomos obrigados a fechar. Segui em frente (DEE, 2019, p. 67-70).

Romper com as estruturas opressivas, para muitas mulheres negras significa romper com a estrutura patriarcal dos casamentos convencionais. As tias solteiras de Miriam Nobre, na percepção da sobrinha, puderam organizar uma condição econômica e social melhor do que a média das pessoas negras para toda a família por terem rompido com a possibilidade do casamento e assumido o emprego público como alternativa de vida. Em relatos da oficina de escrita, romper com casamentos violentos apareceu também como registro de ruptura com a condição de subalternidade e as situações de opressão.

A história da minha família paterna começa em Conservatória, no final do século XIX. Ali, uma jovem que estava na condição de escrava e um jovem filho do fazendeiro se apaixonaram, fugiram e foram levar uma vida modesta para os lados de Batatais. Meu pai contava essa história de seus avós por parte de mãe para explicar porque tinha decidido ir viver em Volta Redonda para começar de novo a história da família. E eu me lembro dessa história sempre pelo ponto de vista do rapaz; sua moral era de que, para ser feliz no amor, era preciso não se apegar a heranças e bens materiais.

Minhas tias devem ter escutado essa história e invertido o sentido. Dos cinco filhos, dois homens e três mulheres, duas foram decidindo ser solteiras e organizar a vida material - a delas próprias e a de todo mundo em volta. Quando eu nasci elas já eram servidoras públicas e uma delas tinha um fusca. Elas, naquela época, viajavam nas férias e nos davam presentes.

(...)

Acho que foi dela a ideia de tornar-se funcionária pública. Ela dizia que, no serviço público, não tinha discriminação de aparência - a pessoa podia ser feia, podia ter um casaco só e puído no cotovelo. Em outras palavras, podia ser negra e pobre. E então ela foi, e depois arrastou a irmã mais nova, ambas passando a atravessar a cidade todos os dias para trabalhar no centro e ter um salário (NOBRE, 2019, p. 139)

Tivemos que sair da casa, eu e minha filha. Era confortável financeiramente, porém insustentável psicologicamente.

Saímos só com as roupas para uma casa de quarto e cozinha. Arranjei um colchão de solteiro emprestado e um isopor para guardar o frango assado. Nas Casas Bahia, depois de uma semana morando naquela casa, consegui comprar um fogão no carnê. Quando o fogão chegou, senti uma felicidade que há tempos não sentia. Na semana seguinte, por sorte, minha prima me vendeu a geladeira de quase 2 mil por 300, parcelado em 3 vezes. O essencial em poucas semanas consegui. $\mathrm{O}$ guarda-roupas era um remendo de cabos de vassoura. 
A tomada de consciência da própria negritude, seja pelo contato com o movimento negro, como no caso de Vanessa Nascimento, seja na valorização estética e política do cabelo crespo podem ser interpretadas como essenciais nos processos de ruptura com a subalternização e a subordinação a padrões de negação e adequação provocados pelo racismo.

O primeiro choque de realidade foi assistir a trechos do filme Amistad em uma reunião da Educafro, uma rede de cursinhos pré-vestibulares para negros. Saí de lá aos prantos e, já no caminho de volta para casa, aluguei o DVD do filme pra entender a história. Ao chegar em casa, a primeira coisa que disse à minha mãe foi que eu tinha encontrado o paraíso, onde só tinha pretos. Só algumas semanas depois entendi que aquelas dezenas de pessoas estavam lá pelo mesmo objetivo: entrar em uma universidade. No mês seguinte eu já estava ajudando como voluntária e me sentindo importante e útil para quem realmente precisava. No início, ajudava só aos sábados; duas semanas depois, eu estava indo de segunda a sábado. Com meu trabalho eu estava, então, colaborando com o ingresso de jovens negros/as nas universidades. Mudando vidas. Eu havia encontrado o sentido para minha vida.

2006 foi o ano da tomada de consciência, de encontros com a herança cultural, religiosa e com veracidade histórica. Somente aos 24 anos descobri que todo esse racismo que foi incutido na nossa sociedade me fez crescer sem entender direito quem era, me fez pensar que cotas raciais eram esmolas, me impediu, por anos, de enxergar meu perfil de beleza na mídia, porque o padrão europeu e branco dominava e, ainda domina, tudo em nossa volta. Foi também durante esse ano que entrei pela primeira vez em um terreiro, o único espaço religioso em que me senti bem, acolhida, em paz. Em casa, minha mãe, evangélica, mudava o cardápio, respeitando o preceito. Tomar consciência da minha identidade me possibilitou de fato ir além, buscar outras informações, outras referências e também a conscientizar meus pares, começando dentro de casa, com meus irmãos e sobrinhos (NASCIMENTO, V., 2019, p. 170).

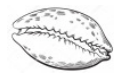

Finalmente chegou o dia. De repente me decidi. Por que eu não posso usar um cabelo que é meu? A partir desse questionamento a possibilidade de usar meu cabelo apareceu na minha frente, esse questionamento me deu certeza de que ser o que ele era me deu força.

Então, no salão especializado em cabelo afro acabou o fim da transição que levava um ano. Por que esperei tanto tempo? A cada mecha cortada a felicidade me transbordava e sentia que estava me libertando. Apenas sorria para o cabelo que descobria.

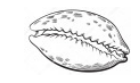

Estava com aquele canecalon já há muitos meses. Bem mais do que o recomendado. A cabeleireira não conseguia desembaraçar, mas não tinha jeito, minha mãe não tinha dinheiro para pagar antes.

Doía muito, e eu chorava. Não fazia sentido. Finalmente, não fez sentido. Pedi pra raspar. 
O trabalho doméstico, citado por tantas teóricas e teóricos negros como a continuidade dos processos de subordinação racial desde o período colonial, é um tópico essencial para se pensar em ruptura. Nos relatos de muitas mulheres, deixar o emprego doméstico foi importante para a conquista da auto-estima, a percepção das situações de opressão e a tomada de caminhos profissionais menos pautados pelas relações colonialistas e escravocratas.

No meu caso, filha e neta de empregada doméstica que migrou para a classe média e estabeleceu um casamento inter-racial, ter uma empregada doméstica em casa, nos cuidados da reprodução da vida e das crianças, pareceu em algum momento essencial para o estudo e o trabalho remunerado. Romper com essa estrutura social, construindo soluções de compartilhamento do trabalho doméstico e de cuidado em casa, com o companheiro branco, foi essencial para que o debate de gênero, raça e classe pudesse ganhar materialidade e coerência. Na perspectiva que defendo, na sociedade igualitária que desejamos não cabem mulheres negras pobres limpando a privada das mulheres negras de classe média que tenham condição de fazê-lo.

Para Eunice Cunha, o fim do trabalho doméstico significa romper com a exclusão social de negras e negros no Brasil. Ao lê-la, cresce a certeza de que romper com o trabalho doméstico mal remunerado e com direitos ainda não garantidos seja a fronteira essencial para romper com a continuidade do modelo escravocrata e colonialista na sociedade brasileira. Não apenas por contratar trabalhadoras domésticas bem remuneradas e com direitos garantidos para que se faça o trabalho considerado menor. Mas, todas as pessoas, tomando para si a responsabilidade de manutenção da própria vida. Rumo a uma sociedade em que negras e negros não sejam eternamente escravos.

E nós, patrícias, precisamos nos mover, sacudir a indolência que ainda nos domina e nos faz tardias. O cativeiro moral para nós negros ainda perdura. Muito a propósito do triste conceito que fazem sobre nós, olhemos o que nos preparam, notemos a fundação desta Escola Luiz Gama com o fim de preparar meninas de cor para serviços domésticos. Por esta iniciativa se vê que para os brancos não possuímos outra capacidade, outra utilidade ou outro direito a não ser eternamente o de escravo.

No passado íamos das senzalas aos eitos, e hoje pretendem nos promover achando que só podemos ir da cozinha à copa.

Mas isto não sucederá, só se não houver negros que sintam bem de perto a necessidade de nos movimentar para nossa reabilitação na vida social (CUNHA, 2019, p. 31-32). 


\section{Perspectiva própria}

Formular perspectiva própria na língua do colonizador é um paradoxo. Por mais que escavemos nossos modos de ser, pensar, agir, sentir, formular, a linguagem para expressar isso tudo é a escrita, no alfabeto latino, em língua portuguesa. As limitações e possibilidades desse paradoxo foram discutidas por pensadoras como Lélia Gonzalez e Grada Kilomba.

Lélia Gonzalez afirmou a existência do pretuguês, a língua trançada nas matrizes africanas, indígenas e europeias, falada por negras e negros e ensinada pelas babás aos brancos. Algumas vezes apontados como erros, outras vezes incorporados como charme, o pretuguês em si seria expressão da resistência negra.

(...) engraçado como eles [sociedade branca elitista] gozam a gente quando a gente diz que é Framengo. Chamam a gente de ignorante dizendo que a gente fala errado. $\mathrm{E}$ de repente ignoram que a presença desse $\mathrm{r}$ no lugar do 1 nada mais é do que a marca lingüística de um idioma africano, no qual o 1 inexiste. Afinal quem é o ignorante? Ao mesmo tempo acham o maior barato a fala dita brasileira que corta os erres dos infinitivos verbais, que condensa você em cê, o está em tá e por aí afora. Não sacam que tão falando pretuguês.

E por falar em pretuguês, é importante ressaltar que o objeto parcial por excelência da cultura brasileira é a bunda (esse termo provém do quimbundo que, por sua vez e juntamente com o abundo, provém de um tronco lingüístico bantu que 'casualmente' se chama bunda). E dizem que significante não marca... Marca bobeira quem pensa assim. De repente bunda é língua, é linguagem, é sentido, é coisa. De repente é desbundante perceber que o discurso da consciência, o discurso do poder dominante, quer fazer a gente acreditar que a gente é tudo brasileiro, e de ascendência européia, muito civilizado, etc e tal.

[...] E culminando pinta este orgulho besta de dizer que a gente é uma democracia racial. Só que quando a negrada diz que não é, caem de pau em cima da gente, xingando a gente de racista. Contraditório, né? $\mathrm{Na}$ verdade, para além de outras razões, reagem dessa forma porque a gente põe o dedo na ferida deles, a gente diz que o rei tá pelado. E o corpo do rei é preto e o rei é escravo (GONZALEZ, 2019, p. 96).

Tal apropriação sagaz da língua é um conforto e uma possibilidade que também carrega a perpetuação da violência.

“(...) a língua, por mais poética que possa ser, tem também uma dimensão política de criar, fixar e perpetuar relações de poder e violência, pois cada palavra que usamos define o lugar de uma identidade. No fundo, através das suas terminologias, a língua informa-nos constantemente de quem é 
normal e de quem é que pode representar a verdadeira condição humana" (KILOMBA, 2019, p. 14).

Como exemplo, Grada Kilomba (2019, p. 14-15) fala das declinações de gênero na língua portuguesa. A identidade feminina não existir, quando os plurais devem ser masculinos, mostra as relações de poder imbricadas na linguagem e justificam a busca da autora para encontrar novas terminologias. Em Memórias da plantação, na tradução para língua portuguesa, Kilomba opta pelo uso de SUJEITO/ SUJEITA, em vez do usual sujeito: substantivo masculino que daria conta da universalidade.

bell hooks também questiona a língua e a linguagem em inúmeros textos e manifesta seu desejo de que sua maneira de falar e escrever não mostrem apenas quem é no presente ou o lugar de onde vem, mas as múltiplas vozes que existem nela. Em A margem como um espaço de abertura radical, afirma que a linguagem é um lugar de luta, e que na linguagem do opressor cursou pós-graduação, escreveu uma tese, se comunicou em entrevistas de emprego. Apropriada da linguagem do opressor, utilizando-a também como seu instrumento de luta, chegou ao centro, carregando a marginalidade de sua experiência vivida.

Quando fui embora e deixei esse espaço concreto das margens, mantive vivas em meu coração formas de conhecer a realidade que afirmam constantemente não apenas a primazia da resistência, mas a necessidade de uma resistência que seja sustentada pela rememoração do passado, que inclua lembranças de línguas feridas, nos trazendo maneiras de falar que descolonializem nosso pensamento, nosso próprio ser (hooks, 2019, p. 289-290).

Essa percepção de muitas camadas permitiu que bell hooks compreendesse, muitas décadas depois, o que sua mãe disse no momento em que foi para uma universidade predominantemente branca: "Você vai aproveitar o que as pessoas brancas têm a oferecer, mas não precisa amá-las”. bell, Lélia, Sueli ou qualquer outra mulher negra que avança nas brechas na hegemonia carrega o poder de separar o conhecimento útil que pode adquirir dentre os dominadores sem ser cooptada ou aderir aos pactos que mantêm a hegemonia da branquitude. "Ela estava dizendo que não é necessário se entregar totalmente a eles para aprender", disse bell hook sobre a recomendação da mãe (hooks, 2019, p. 291).

A língua portuguesa do colonizador, instrumento de opressão, é também apropriada e forjada pelas mulheres negras que utilizam esta língua para contar a história de um ponto de vista próprio, desde as margens, como resistência. 
Ademais, mulheres negras têm lidado como paradoxo de escrever uma perspectiva própria na língua do colonizador apoiadas em muitos pilares. O primeiro deles, conforme cunhado por Jurema Werneck, é o da anterioridade. O segundo, já bastante mencionado em outros momentos deste trabalho, o da ancestralidade que conecta, ao mesmo tempo, perspectivas históricas, filosóficas e espirituais, sem a separação inventada na modernidade europeia e imposta pelo colonialismo e o epistemicídio.

Começo isto aqui com esta perspectiva: de anterioridade. De uma história que não é fundada pelos europeus (ainda que mais recentemente tenha sido profundamente influenciada por eles). De outras possibilidades interpretativas ou de diferentes possibilidades de se estabelecer marcos para se recontar uma história. Reconheço que a capacidade de dar nomes às coisas fala de uma situação de poder. Ou seja, de uma possibilidade de ordenar o mundo segundo bases próprias, singulares, desde pontos de vista individuais quanto a partir de coletividades, de povos inteiros. Tratase de uma posição de privilégio. Ainda que eu não vá discutir aqui quais e quantas armas estiveram envolvidas na obtenção destes privilégios - mas não me é possível esconder o fato de que se tratava (e se trata) de armas. Ao nomear a luta das mulheres a partir de sua perspectiva - mulheres brancas burguesas europeias nas décadas a partir de 1970 - as formuladoras iniciais da teoria feminista trouxeram para o conceito recém-criado a perspectiva ocidental, e mais: fundada numa ignorância profunda acerca das demais mulheres do mundo. Além de se fundamentarem num individualismo crescente que teve o capitalismo como pano de fundo. Até que ponto o conceito "feminismo" é suficiente para abarcar todas as mulheres, todo ativismo, toda luta?

Para nós mulheres negras - compreendidas como uma diversidade incomensurável, porém marcadas por desigualdades que têm origem na inferiorização e exploração - as múltiplas ações políticas que empreendemos atravessam diferentes níveis de atuação, diferentes campos da existência, marcadas por encontros conflituosos ou violentos com o Ocidente, com o patriarcado, com o capitalismo, com o individualismo... É suficiente chamar isto de feminismo?

(...)

Aqui, este relato tem a utilidade de expor um dos pressupostos do papel feminino negro vivido pelas mulheres no Brasil. Estes pressupostos falam de dimensões de luta, de instabilidade de posições, de poderes de agenciamento e transformação capazes de serem vividos pelas mulheres. Falam da disponibilidade para a luta e das possibilidades de êxito que a luta traz. Falam da responsabilidade das mulheres em relação ao grupo. E da existência de uma coletividade de interesses, a que cada indivíduo deve se reportar. Falam do poder masculino sendo questionado. Falam do poder da riqueza sendo questionado. Falam da revolução onde a riqueza muda de mãos. Falam da presença das mulheres no espaço público, sua capacidade de liderança, de ação política. Falam de Oxum, a ialodê primordial, segundo a tradição. A orixá marcada pela sensualidade, pela força de vontade e capacidade de realização. E celebram a figura das ialodês, mulheres que se colocam como agentes políticos de mudança, detentoras principais das riquezas conquistadas. 
Assim, recolocam a dimensão ativista que as mulheres negras têm vivenciado, desde seu passado (ou presente) africano até o cotidiano da diáspora. Ainda que se tenha perdido o rastro temporal da origem desta história exemplar, é possível afirmar que as lutas contra o patriarcado e a dominação política e econômica associadas a ele vêm de muito longe para nós mulheres negras. E o vigor com que esta narrativa vem sendo atualizada até o século XXI assinala sua pertinência na modernidade ocidental, guardando uma perspectiva de continuidade fundamental ao longo dos séculos. O feminismo, como teoria, veio depois (WERNECK, 2019, p. 213-223).

De todas, herdo a certeza de que estou amparada, a certeza de uma ancestralidade que vibra não apenas em mim, mas em várias, em todas as mulheres negras.

$\mathrm{Na}$ trança afro-brasileira, como colocada por Allan da Rosa, das origens africanas, indígenas e europeias, se coloca uma perspectiva própria de leitura e ação no mundo, que nada tem a ver com um paradigma superado de democracia racial e harmonia de três raças. Mas da alquimia possibilitada pelo saber agregador de negras e negros que se atualiza há centenas de anos, permitindo estarmos vivas e vivos apesar do genocídio conformado no dispositivo de racialidade e biopoder.

A dimensão ancestral, que é histórica, filosófica e espiritual, aparece nos relatos de mulheres negras de variadas formas. Atentas aos sinais, ou o soprar dos ventos, que vibram do tempo mítico ou do passado pela memória, essas mulheres constroem existências coletivas abundantes e criativas, apesar do racismo.

Acredito que o universo nos presenteia com um talento e que somos cobrados sobre o que fazemos com esse presente. Para isso, temos que estar atentos aos sinais (DIAS, 2019, p. 50).

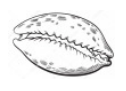

Por que evoco essa história? Porque um dia, antes de retornar para São Paulo, estive num terreiro para o plantio de um Baobá, o Emboandeiro, a Árvore Sagrada, o orixá Tempo. Era em círculo que o plantio e o culto aconteceriam. Os atabaques bateram para o sagrado se manifestar e, diante de tal manifestação, a Senhora dos Ventos, a dona dos movimentos, se apresentou, me cumprimentou e, na frente dela, eu apenas agradeci. Eu renasci. Ao retornar para São Paulo, vi minha vida mudar e me vi mudar diante da vida.

Quando o vento sopra, o melhor que se pode fazer é ficar leve e deixar que Ela - a Senhora dos Ventos - conduza. Assim foi: saí da casa da minha mãe e fui demitida do projeto que me daria condições para me manter em uma vida independente. Sair desse trabalho foi essencial para eu entender que não precisava mais me submeter a projetos que não faziam sentido para a narrativa de mundo e de relações profissionais que eu queria construir. Não trabalhar mais em projetos $100 \%$ encabeçados por brancos foi uma escolha que fiz naquele momento em que guardei as 
minhas coisas na mochila, quando, ainda sem entender o que eu faria da minha vida profissional, sabia que devia confiar. Quem tem caminho caminha e não caminha sozinho (FREITAS, 2019, p. 119).

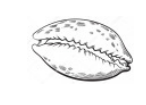

Olho o espelho e vejo um legado de saberes e narrativas marcados pela ancestralidade no meu corpo e traços. Carrego comigo o livro do mundo, histórias e valores meus e de mulheres iguais a mim, um grande e acolhedor espelho preenchido de amor, de coragem e da energia vital de minha mãe, avó, tias, irmãs, primas, comadres, amigas, parceiras e referências. O reflexo do meu espelho é a história de vida de mulheres negras ancestrais que, dotadas de sensível cosmovisão, sempre estiveram em movimento, semeando saberes, observando o tempo e regando as tradições de um povo, em um exercício de fé, evolução, resistência e sobrevivência. Mulheres que estão arando e fertilizando esse chão para que no futuro tempo do presente as vivências e trajetórias dos povos em diáspora tenham caminhos de mais afeto e prosperidade (FAUSTINO, 2019, p. 35).

\title{
Experiências espirituais também são descritas como momentos marcantes no
}

reconhecimento de si mesma como Ser, de uma história, trajetória e perspectiva próprias.

De um devir que é também voltar às raízes e à própria casa

\begin{abstract}
Alguns dias depois, eu me refrescava com uma cerveja pré-jantar, admirando a vista para a Ilha de Goré e pensando que daquele porto podiam ter saído boa parte dos meus, quando um colega sentou ao meu lado e falou, de passagem: "Eu me esqueci de dizer: Gogo me ligou há uns dias pedindo para você ir fazer uma visita". Meu coração palpitou. Eu tinha encontrado essa vó do nosso amigo na casa deles, em Soweto, apenas uma vez, brevemente, mas simpatizado para sempre - ainda mais quando eu soube que ela é uma pessoa com dons ancestrais de cura. De volta a Joburg, ainda levei um tempinho para conseguir vê-la. Em uma manhã de sábado, ela estava curvada varrendo o quintal de terra com uma vassoura de mão e levantou a cabeça quando me viu descendo do carro: "Sawubona, Gogo". Ela gostou da saudação em zulu. Com sorriso de vó, me chamou pra dentro fazendo um gesto com um braço. Entrei expandida pelo mesmo frenesi que me causavam os barulhos da casa do Pai Veludo. Tomamos chá, brincamos com as crianças, comemos com os adultos, assistimos à televisão, antes que finalmente os ossos falassem. E ali, no chão do quartinho de ervas da Gogo, eu aprendi que intuição e sonhos são muito próximos e as armas mais naturais para a própria proteção; que religião não importa, mas que é fundamental se conectar com Deus e com todas as divindades; que ancestralidade é nossa perspectiva de presente e de futuro; que é um dádiva se acoplar à natureza, sobretudo com a própria; que é importante ter coragem de sair, mas que é igualmente importante saber voltar pra casa (SILVA, S., 2019, p. 155).
\end{abstract}

Tais experiências estruturadas e nomeadas, assim como os sinais e ventos mais difusos, permitem tomar decisões e executá-las de uma perspectiva própria, não explicada 
por um discurso de pretensa racionalidade ou cálculo estruturado de causa e efeito. Talvez daí venha, apesar das condições de precariedade que poderiam gerar a tristeza necessária ao samba branco, a alegria presente na raiz do samba, conforme revela letra de Jovelina Pérola Negra.

Logo eu com meu sorriso aberto

O paraíso perto, a vida melhorar

Malandro desse tipo

Que balança mais não cai

De qualquer jeito vai

Ficar bem mais legal

Pra nivelar

A vida em alto astral (PÉROLA NEGRA, 2019, p. 109).

Um senso de humor próprio, manifestado em variadas figuras de linguagem e jogos comunicativos próximos da ironia configura relações, justificativas, argumentos retóricos. A forma como Obá Biyi, no relato de Maẽ Stella de Oxóssi, contorna a determinação do português da feira de não vender fiado, ainda deixando o homem com vergonha, ou a forma como Maria Firmina dos Reis se desculpa por uma escrita que não estaria à altura dos cânones, lembra as peripécias empreendidas por minha avó que invertiam tanto os sinais da comunicação que garantiam a ela vantagens em transações financeiras.

Performando a ingenuidade e a inferioridade que seus interlocutores viam nela, minha avó comprou uma casa com um impensável desconto de 40\%, com os custos de documentação já incluídos, deixando abismada a filha formada em economia. Do mesmo modo, quando era diarista e guardava cada centavo que conseguia economizar, oferecia dinheiro emprestado à patroas que percebia em apuros, cobrando juros e correção, além de presentes como bules de prata, jogo de chá de cerâmica inglesa e outros mimos que herdei de sua astúcia. Mais que os bens materiais em si, me parecia que minha avó se divertia e se sentia vingada ao fazer exatamente o que queria, ter o que desejava e enrolar o Ser tão seguro de si.

A iyalorixá tirou das orelhas os brincos, de ouro maciço, depositando-os no balcão; - "que o cavalheiro fizesse o favor de liberar as compras mediante a guarda da jóia; assim que chegasse ao Terreiro, mandaria portador com a importância devida. Ela, Oba Biyi, confiava nas pessoas de bem; certamente as argolas lhe seriam restituídas..." O português, envergonhadíssimo, pediu mil desculpas à senhora. (Ele mesmo faria publicidade deste episódio passado com a Mãe de Santo do Axé Opô Afonjá)! (OXOSSI, 2019, p. 106). 
Não a desprezeis, antes amparai-a nos seus incertos e titubeantes passos para assim dar alento à autora de seus dias, que talvez que com essa proteção cultive mais o seu engenho, e venha a produzir coisa melhor, ou quando menos, sirva esse bom acolhimento de incentivo para outras, que com imaginação mais brilhante, com educação mais acurada, com instrução mais vasta e liberal, tenham mais timidez do que nós (REIS, L., 2019, p. 24).

Parece-me que Nilma Bentes, ao afirmar o "afro bom humor herdado", necessário à luta, se remete à mesma ordem de astúcia citadas acima.

Nós, do movimento negro de hoje, cientes de que tudo que fizermos ainda será muito pouco diante da magnitude da nossa causa, temos, mais do que nunca, de continuar fazendo cada qual a sua parte, de preferência sem brigas, conscientes de que o trabalho será, no mínimo, triplicado. Para dar conta disso, é de bom alvitre procurar ativar o afro bom humor herdado, sobretudo nos momentos de maior tensão. E, uma vez que na morte teremos toda a eternidade para descansar, então, mãos à obra! (BENTES, 2019, p. 161).

Considerando como pressuposto da astúcia, chegar sempre devagar, no passinho, como escreveu e cantou Dona Ivone:

Eu vim de lá, eu vim de lá pequenininho

Mas eu vim de lá pequenininho

Alguém me avisou

Pra pisar nesse chão devagarinho

Alguém me avisou

Pra pisar nesse chão devagarinho

Sempre fui obediente

Mas não pude resistir

Foi numa roda de samba

Que eu juntei-me aos bambas

Pra me distrair

Quando eu voltar à Bahia

Terei muito que contar

Ó padrinho não se zangue

Que eu nasci no samba

Não posso parar

Foram me chamar

Eu estou aqui, o que é que há (LARA, D., 2019, p. 71)

Esta perspectiva própria também pautou estudos acadêmicos e, em outros países da diáspora negra, configurou verdadeiros campos de estudos. Luiza Bairros, escreveu sobre a 
tradição feminista norte-americana de teorizar a partir de ponto de vista específico, declarando-o e teorizando também sobre ele.

É desse modo que a afro-americana Patricia Hill Collins desvenda uma longa tradição feminista entre mulheres negras com base no pensamento daquelas que desafiaram ideias hegemônicas da elite masculina branca expressando uma consciência sobre a intersecção de raça e classe na estruturação de gênero. Tal tradição constituiu-se em torno de cinco temas fundamentais que caracterizariam o ponto de vista feminista negro: 1) o legado de uma história de luta, 2) a natureza interligada de raça, gênero e classe, 3) o combate aos estereótipos ou imagens de controle, 4) a atuação como mães, professoras e líderes comunitárias, 5) e a política sexual.

A autora considera como contribuição intelectual ao feminismo não apenas o conhecimento externado por mulheres reconhecidas no mundo acadêmico, mas principalmente aquele produzido por mulheres que pensaram suas experiências diárias como mães, professoras, líderes comunitárias, escritoras empregadas domésticas, militantes pela abolição da escravidão e pelos direitos civis, cantoras e compositoras de música popular.

Assim, através de depoimentos, documentos, letras de música, autobiografias, novelas e textos acadêmicos de mulheres negras, Collins traça um perfil de uma tradição intelectual subjugada também em função de critérios epistemológicos que negam a experiência como base legítima para a construção do conhecimento. $O$ pensamento feminista negro seria então um conjunto de experiências e ideias compartilhadas por mulheres afro-americanas que oferecem um ângulo particular de visão do eu, da comunidade e da sociedade, ele envolve interpretações teóricas da realidade de mulheres negras por aquelas que a vivem (BAIRROS, 1995, p. 137-138).

A perspectiva teórica própria das feministas negras norte-americanas, conforme descrição de Luiza Bairros, que considera os saberes produzidos na experiência tem relação direta com a necessidade de materializar discursos em ações, conforme aparece no relato de Ariane Cor e de Miriam Nobre, contando da atuação política em países africanos da Marcha Mundial das Mulheres.

O desafio de aprendizado que carrego comigo a partir desse encontro com Jurema Werneck é a iniciativa de receber da outra para me entregar a fim de construir um discurso potente que não apenas rompa o silêncio, mas que também transforme os nossos saberes em linguagem e a linguagem em ação, como é proposto por Audre Lorde. O meu desafio com o Minas Programam agora é contar uma história das mulheres na tecnologia que tenha potência para ser transformada em experiência coletiva e ação política. (...)

Desde 2015 aprendemos que, para o discurso ser potente, ele precisa ser polivocal, porque somos muitas e temos muitas características particulares. Nem todas querem ser programadoras. Os nossos saberes e 
desejos vão além dos interesses do mercado; nós queremos construir alternativas de produção da vida (COR, 2019, p. 28).

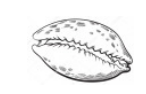

(...) Eu sempre gostei na Marcha dessa coisa da materialidade. Nossa identidade comum se constrói por meio da ação e essa ação se materializa. Em 2005, resolvemos escrever uma Carta das Mulheres para a Humanidade. Queríamos projetar um mundo diferente para viver e parar de ficar apresentando demandas aceitáveis ao poder público e aos organismos multilaterais. Tudo utopia. Porém, conseguimos concretizá-la como em uma colcha de retalhos: cada país expressou em um retalho sua visão desse mundo que queremos e já estamos construindo. Os retalhos iam sendo costurados conforme a Colcha ia viajando pelo mundo, começando na cidade de São Paulo e terminando na cidade de Ouagadougou, em Burkina Faso. As ativistas da Marcha de Burkina propuseram, como parte da Ação, que juntássemos recursos para uma bolsa de estudos em jornalismo para uma garota. Eu achei um absurdo, assistencialista, pontual, que não resolveria nada, pois temos que lutar pela universidade pública. A primeira doação veio do Haiti com uma cartinha, desejando que essa companheira seguisse conosco. Isso me fez perceber que não entendia muitas coisas. Um movimento para existir tem que fazer coisas concretas, elas diziam (NOBRE, 2019, p. 141).

No Brasil, uma das grandes realizações das mulheres negras organizadas foi enegrecer o feminismo brasileiro, não permitindo, depois de 3 décadas de debate e ação política constante, que se discuta gênero ou feminismo sem pautar a importância do racismo na configuração do machismo e do sexismo, gerando desigualdades também entre as mulheres. O sujeito coletivo mulheres negras, responsável por esse feito, teve uma filha de Ogum com sua espada nas mãos abrindo o caminho de travando as batalhas necessária a essa conquista: Sueli Carneiro.

Enegrecendo o feminismo é a expressão que vimos utilizando para designar a trajetória das mulheres negras no interior do movimento feminista brasileiro. Buscamos assinalar, com ela, a identidade branca e ocidental da formulação clássica feminista, de um lado; e, de outro, revelar a insuficiência teórica e prática política para integrar as diferentes expressões do feminino construídos em sociedades multirraciais e pluriculturais. Com essas iniciativas, pôde-se engendrar uma agenda específica que combateu, simultaneamente, as desigualdades de gênero e intragênero; afirmamos e visibilizamos uma perspectiva feminista negra que emerge da condição específica do ser mulher, negra e, em geral, pobre, delineamos, por fim, o papel que essa perspectiva tem na luta antirracista no Brasil. Ao politizar as desigualdades de gênero, o feminismo transforma as mulheres em novos sujeitos políticos (CARNEIRO, S., 2019, p. 166) 


\section{Proposição de caminhos de emancipação individual e coletiva}

Poder de fala. Essas três palavras me acompanham e acredito nelas piamente. Eu tenho o poder de fala. Um mundo pode se construir a partir da minha fala. Eu luto para que um mundo, um velho mundo se desconstrua com a minha fala (FREITAS, 2019, p. 118).

A escrita de Maitê Freitas sobre o poder da palavra apresenta o princípio da cosmovisão africana de que a palavra é atributo do preexistente, que promove realizações, transforma o mundo, é veículo primordial do conhecimento que a tudo envolve, adentrando e movendo coisas, lugares e seres (ROSA, 2019).

A palavra, escrita e falada, portanto, vem antes da realização material no mundo. O que cada uma dessas mulheres negras escreveu como proposição, em conexão com as memórias de cada uma e de muitas, é o passo inicial para a realização do caminho.

Além de interrupção do racismo e do genocídio negro, diante dos inúmeros desafios apresentados a todas e todos, as mulheres negras são detentoras de conhecimentos que podem se realizar em condições de vida melhores para todas as pessoas. A realidade que subjuga, subordina e extermina negras e negros também não está propiciando condições adequadas de vida a não negros. Em todo o mundo, para manter padrões exagerados de consumo e conforto a poucos, a maioria das pessoas perde condições mínimas de existência, ou não se alimentam, ou comem veneno; ou não tem onde morar ou pagam valores exorbitantes; estão expostos às mudanças climáticas que atinge os mais pobres. Guardadas as particularidades de cada território e grupo social, muitas e muitos são deixados morrer ou exterminados para que pouquíssimo possam viver.

Jurema Werneck coloca como desafio às ialodês contemporâneas readquirir o poder de proteger, nutrir, possibilitar beleza, saúde e prazer a todas e todos.

As ialodês contemporâneas enfrentam um desafio que talvez só tenha algum patamar de comparação com a mundialização econômica mercantil que deu origem à diáspora via tráfico-transatlântico de escravos. É preciso então, novamente, por abaixo as novas regras do novo reino para que possamos, novamente, readquirir o poder e a riqueza que Oxum requisita (WERNECK, 2019, p. 232).

Tendo o passado como principal referência temporal, só se pode orientar o presente e, consequentemente o futuro, ao olhar o passado. Pela memória, fio que une temporalidades, é possível imaginar o porvir. Referência banto conforme apresentada por 
Fu-Kiau, também presente dentre os iorubás e os povos Akan, no adinkra Sankofa: "retornar ao passado para ressignificar o presente e construir o futuro".

Imagem 14: Adinkra Sankofa. "Retornar ao passado para ressignificar o presente e construir o futuro".

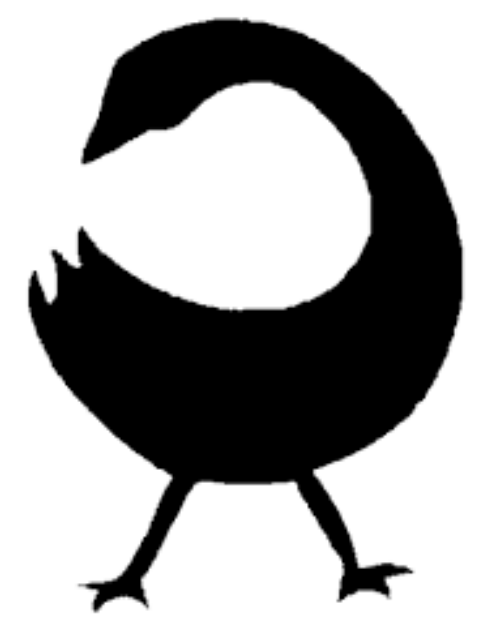

Fonte: Ocupação Abdias Nascimento / site Itaú Cultural

(...) Houve o retorno do olhar para a terra, para o plantio sustentável e para os animais, além da seguridade da autonomia alimentar, tão discutida atualmente e que afeta as comunidades tradicionais. Mais um passo rumo ao futuro. Como cantamos no ponto de Jongo da Comunidade Jongo Dito Ribeiro: "Planta seu milho, colhe seu milho e faz seu pão. Está na ngoma... Está na ngoma da sua mão". Da nossa mão (RIBEIRO, A., 2019, p. 25).

Dos saberes tradicionais, das táticas de existência que nos permitiram chegar até aqui e do olhar amplo que mulheres negras têm, desde a base da pirâmide, para todos os grupos sociais, estão sendo forjadas soluções para os problemas coletivos. As respostas de que precisamos estão nas raízes, enterradas no canto do jongo, em caixas de fotografias, ensinamentos de avós, modos de fazer cotidianos.

Encontrei minha vó costurando na máquina. Com meu cutucão, ela levantou a cabeça para o meu lado, olhando por cima dos óculos: "Olha o que eu achei!". Ela viu a caixa e as fotos que eu segurava, subiu o olhar para mim e falou, risonha: "Ô gata curiosa. Cadê as outras?". Chamamos o vô, que cochilava na frente da televisão, e sentamos na mesa da área diante dos álbuns e das fotos. Fiquei tão passada que eu não estava perguntadeira. Passada, não. Acho que o termo é apaixonada, ou emocionada - qualquer coisa assim. Foi naquela tarde, naquela mesa, que eu soube que meu vô comprou a máquina de fotografar tão logo entrou para o Exército; que eu conheci os rostos e nomes da minha bisa, mãe da vó, e dos meus bisos, pais do vô; que eu conheci o rosto e a história da minha tia avó, irmã do vô, cuja morte precoce traumatizou a família; que 
eu vi as feições jovens e felizes de tios e tias, primos e primas, amigos e amigas; que eu soube que meu vô passou tempos dividido entre dois noivados, até se decidir pela minha vó - e eu entendi porque ela era tão ciumenta -; que eu vi familiares bêbados brincando com armas reais; que eu soube que as crianças pulavam carnaval inalando loló dado pelos adultos; que eu vi família e amigos se amando; que eu tive a visão do interior em que minha família existiu. Foi naquela tarde, naquela mesa, que eu me vi.

(...)

"Vó, me conta alguma coisa da história da bisa?". E ela contou o que ouviu: que seu avô era um preto, bem preto, mais preto do que o vô, azul mesmo. E esse vô veio direto da África e foi feito escravo na Bahia. Era homem muito, muito forte e bravo, tão bravo que se recusava a falar português e sempre era castigado por isso. Disse que a bisa também era escravizada, mesmo depois da lei, e que fugiu de lá escondida em um navio com a minha vó no bucho, comendo comida roubada na espreita, ou não comendo por vários dias, até desembarcar no litoral de São Paulo e caminhar muitíssimos quilômetros interior adentro, onde minha vó nasceu; que a bisa era uma mulher difícil e da vida, que sabia de muitas coisas que não se usa mais saber (SILVA, S., 2019, p. 151-156).

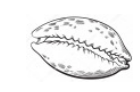

Esta é a herança que recebi da minha bisavó. Pode ser que a gente tenha que atravessar o oceano ou os rios para plantar as raízes que aterram nossa memória na materialidade da vida (NOBRE, 2019, p. 144).

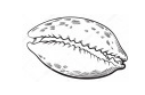

Acredito que, a partir do surgimento histórico dessa mulher negra que tem seu olhar situado nas periferias e que compreende a linguagem de programação, é possível que novas visões de futuro sejam delineadas para toda a sociedade, porque a tecnologia desenvolvida por essa mulher importa para o desenvolvimento de ciências e tecnologias melhores para todos (COR, 2019, p. 29).

O trabalho ativo de memória tem sido empreendido por mulheres negras em toda a diáspora. Recentemente, Gabriela Leandro Pereira, docente na Faculdade de Arquitetura e Urbanismo da UFBA, tem mapeado a história de seus familiares por meio de conversas com pessoas mais velhas, pesquisas em álbuns de fotografia e em arquivos públicos. No grupo de estudos que coordena na universidade, alunas e alunos negros de arquitetura têm escavado as origens dos bairros onde vivem a partir das histórias contadas pelos familiares, que se entrelaçam e complementam, possibilitando outras interpretações da urbanização da cidade de Salvador, contada desde os movimentos de moradia, mutirões, casas das avós e das tias.

Ao pesquisar as origens familiares de Sueli Carneiro também pude experimentar a escavação de informações que guardam muito mais do que dados objetivos sobre o passado 
de nossos ancestrais, guardam também chaves de interpretação e análise do hoje, guardam as táticas que permitem desenhar possibilidades de futuro. E quanto mais escavamos, mais perto da escravização e do tráfico negreiro chegamos. Lugares-tempo fundamentais para chegar à origem africanas e aos entrançamentos do afro-brasileiro.

Abdias do Nascimento afirma a necessidade de evocar o tráfico e lembrar permanentemente da escravidão, não como forma patológica de auto-flagelo, mas como parte importante de apropriar-se do ser negro/ afro-brasileiro:

Erradicá-los [tráfico negreiro e escravização] da nossa bagagem espiritual e histórica é o mesmo que amputar o nosso potencial de luta libertária, desprezando o sacrifício dos nossos antepassados para que nosso povo sobrevivesse.

(...)

Escravidão não significa para nós um vocabulário petrificado nas páginas da História. Não é longinqua nem abstrata. Antes, é uma palavra que nos devolve parte viva e dinâmica de nossa própria carne e espírito: os nossos antepassados. A violência que eles sofreram é a violência que tem se perpetuado em nós, seus descendentes. A opressão de ontem forma uma cadeia no espaço, uma sequência ininterrupta no tempo, e das feridas em nosso corpo, das cicatrizes em nosso espírito, nos vêm as vozes da esperança. Embalados na esperança, os negros brasileiros não perderam sua alegria e esse gosto de cantar e de dançar a vida, e assim se preparam para os momentos da luta mais difícil que virá (NASCIMENTO, A., 2019, p. 113-115).

Mas não é de qualquer perspectiva que nos interessa retomar os detalhes do tráfico negreiro e da escravização, sob o risco de reforçar os estereótipos vigentes. Edson Cardoso afirma que, por anos, ao denunciar a brutalidade do sistema escravista, ao fazê-lo sem reconhecer negras e negros como sujeitos ativos, acabava por reforçar a imagem racista sobre nosso passado e presente.

Até que tropecei em uma citação que reproduzia a fala de um homem negro escravizado, encontrada nos autos criminais. Ele matou um dono de fazenda, ou um feitor, o livro não esclarece e, respondendo a um interrogatório, disse: "matei lobisomem, não matei homem". É a fala de uma humanidade avassaladora. Essa é a história (o ponto de vista, a perspectiva) que nos interessa: a resistência à opressão que é a afirmação de plena humanidade. (CARDOSO, 1992, p. 72).

Acessar nossas histórias escondidas nos arquivos públicos e privados, nos cantos e danças populares, nos gestos e modos de fazer da memória-hábito é também o modo de evocar nossos traumas e fantasmas, para enterrá-los de forma adequada ou - ao lembrar na 
consciência - esquecer na repetição e no trauma. Esse acerto com nosso passado é essencial para forjar palavras que dêem conta do futuro desejado.

Em uma conversa com Sueli Carneiro, ela me disse que talvez a literatura pudesse apresentar aquilo que passaremos a construir como política de movimento negro daqui para a frente. Com o mito da democracia racial desmascarado, a consciência da necessidade de políticas inclusivas e as práticas de resistência operando, qual a nossa proposição de futuro? "Se os estereótipos a nós atribuídos não nos servem, quem é a mulher negra que apresentamos? Talvez a literatura possa imaginar as possibilidades".

Achille Mbembe em Crítica da razão negra, pergunta: "Como retomar, da estaca zero, a interrogação sobre a diferença negra, compreendida dessa vez não como um gesto de ressentimento e de nostalgia, mas como um gesto de autodeterminação? Esta nova interrogação pode ser feita sem uma crítica da memória e da tradição, isto é, sem um esforço consciente para discernir aquilo que, na diferença, é capaz de oferecer possibilidade de criação ou recriação" (MBEMBE, 2018, p. 167).

Segundo o autor, a memória da escravidão não pode ser confundida com o apelo a um passado de desventura e degradação. “A passagem da escravidão à liberdade não exigia apenas um tratamento sutil da memória. Requer ainda uma reformulação das inclinações e dos gostos. Ao sair da escravidão, a reconstrução do indivíduo implicava, pois, um enorme trabalho sobre si mesmo, trabalho este que consistia em inventar uma nova interioridade" (MBEMBE, 2018, p. 168).

Como tem sido tecido ao longo deste trabalho, a memória trabalhada na escrita de si é uma possibilidade de inventar essa nova interioridade, rompendo com a subordinação e a subalternização, fissurando o dispositivo de racialidade e o biopoder. É exatamente na apropriação das histórias escondidas, em narrá-las e difundi-las, que temos a possibilidade de criar futuros. Uma função evocativa e libertadora, nas próprias palavras de Mbembe, em contraposição à nostalgia ou à melancolia.

Cada retorno para meu quarto de origem era uma viagem naquelas fotos, mas fui voltando cada vez menos e me deslocando cada vez mais, tanto que morei em Joanesburgo, na África do Sul. Viajando com frequência pelo continente africano, estava, em certa medida, habituada à magia do retorno. Porém, chegar para duas semanas de trabalho em Dacar, no Senegal, às vésperas do meu aniversário, perdida em angústias pessoais e dramas sociais, foi diferente: eu olhava para as pessoas na rua, os taxistas, os comerciantes e só sentia vontade de chorar de emoção. Liguei pra minha mãe na primeira oportunidade, pois precisava contar que estava todo mundo ali: meu vô, meu biso, minha bisa, as tias, todo mundo. "Achei" (SILVA, S., 2019, p. 154). 
Sandra Silva, a partir da caixa de fotografias do avô, conhece histórias de família e memórias coletivas de mulheres negras. Pela observação das fotos, mas, principalmente, pelas perguntas e conversas provocadas pelas imagens. Ao chegar ao Senegal, reconhece nas pessoas os rostos e memórias-hábitos de sua própria família. Sandra não sabe se o território hoje chamado Senegal é o lugar de origem de algum ou alguns de seus antepassados. Talvez um teste de DNA, pelas ciências biológicas, ajude a encontrar uma confirmação ou uma refutação para a hipótese despertada em sua imaginação. Talvez a voz interna da memória-hábito seja eloquente o bastante - e menos perigosa, por não oferecer seus dados genéticos a grandes corporações - para assumir essa origem africana.

Fato é que, do trabalho de memória - de juntar os cacos lembrados, tomar consciência dos hábitos, buscar em arquivos e conversas - ficarão lacunas. Necessariamente. Talvez essas lacunas possam ser preenchidas de forma propositiva pela literatura, como intui Sueli Carneiro; pela ficção científica, como tem afirmado a norteamericana Walidah Imarisha, ou naquilo que a também norte-americana Saidiya Hartman nomeou fabulação crítica.

Antes de explicitar cada uma dessas noções, vale dizer que autoras negras já criam narrativas completas, de histórias possíveis de mulheres negras, a partir da combinação de pesquisa em arquivos e escrita ficcional. Já foi citado neste trabalho o romance Um Defeito de Cor, de Ana Maria Gonçalves (2007). A partir de pesquisas em arquivos, em que a autora compilou informações sobre diversas mulheres e homens escravizados, foi montado o quebra-cabeças da personagem principal Kehinde e de diversas outras mulheres e homens negros que compõem a trama, incluindo Agontimé, que teria sido rainha no Reino do Daomé e vendida como escravizada no Brasil depois da morte do marido. Duas décadas antes, a nobel de literatura Toni Morrison havia publicado Amada, romance cuja personagem principal foi inspirada em uma notícia de jornal, do julgamento de uma mulher escravizada que assassinou a filha.

Apresento categorias analíticas contemporâneas que podem ser passos consistentes nos caminhos de futuro trilhados por mulheres negras, a partir da pesquisa em arquivos combinada com a escrita, também de ficção.

Saidiya Hartman, em busca das próprias origens, consultou, ainda quando era estudante de graduação, arquivos de testemunhos de pessoas escravizadas do Alabama, Sul dos Estado Unidos. De forma incomparavelmente diferente da realidade brasileira, nos Estados Unidos, entre 1936 e 1938, foram coletados 2.300 relatos de pessoas que haviam 
sido escravizadas. Foram organizados, em 1941, dezessete volumes sobre a história da escravidão negra no país, a partir dos relatos de negras e negros que haviam sido escravizados. Ao mesmo tempo que não tenho a dimensão do que poderia significar ter esse volume de dados registrados no Brasil, e sentir raiva por nenhuma política nesse sentido ter sido estruturada aqui - pelo contrário, o objetivo sempre foi negar, apagar, não contar, distorcer - sinto, com convicção, que há muitos relatos escondidos, há espera por serem encontrados. Imagino que estejam nos cartórios, fóruns, igrejas, e também nos arquivos privados de famílias escravocratas. Quanto mais pessoas, grupos e instituições se dedicarem às escavações, quanto antes reuniremos um volume considerável de informações. De posse destes documentos, pesquisadoras e pesquisadores do futuro vão recontar a história do Brasil e o que compreendemos sobre a resistência de negras e negros à escravidão.

Na verdade, esse movimento já começou e tem crescido. Conforme Giovana Xavier, Juliana Barretos Farias e Flávio Gomes narram na apresentação do livro Mulheres negras no Brasil escravista e do pós-emancipação (2012) como os estudos sobre a escravidão se consolidaram no Brasil das últimas décadas. Até 1960 falava-se de uma escravidão genérica, análises do cotidiano, cultura e pessoas foram ganhando espaço; diferenças entre regiões e atividades produtivas foram desenhadas; e, atualmente, as análises de alforrias, quilombos, irmandades, revoltas têm apresentado experiências das pessoas negras.

A coletânea publicada por eles em 2012 reuniu artigos de 20 especialistas, de todo o país, que reconstroem a vida de mulheres negras. As biografias dessas personagens foram o centro do livro. "Embora só o começo, esta coletânea dá alguns passos nessa direção [de abordar mulheres negras como protagonistas das diversas histórias], revelando silhuetas até então encobertas pelas hierarquias de gênero e raça" (XAVIER et al, 2012).

Enquanto seguimos este caminho, ainda sem um grande volume de dados, e assumindo também que determinadas lacunas jamais serão preenchidas, os estudos de Hartman são ótima referência. Ao pesquisar os arquivos do Alabama, encontrou o nome de sua tataravó. As respostas da avó a qualquer pergunta sobre o período da escravização eram de que não se lembrava de nada. Em meio às inúmeras reflexões provocadas pela falta de informação, sobre a escolha por lembrar ou esquecer, ou a recusa de contar, chamou sua atenção a quantidade de vezes que certas frases apareciam nos testemunhos: "Eu não conheci meu pai". "Eu perdi minha mãe". "Meus filhos foram espalhados em diferentes direções”. (HARTMAN, 2008, p. 15-17). Estava criada uma obstinação por preencher as lacunas, ainda mais de, anos depois, voltar ao arquivo do Alabama e não encontrar sequer o 
registro da tataravó. Teria confundido nomes? Encontrado fantasmas? Inventado? Na ocasião escreveu sobre quão ilusórios e escorregadios são os arquivos da escravidão.

Acessar o arquivo é como entrar em um necrotério; possibilita uma visão final e permite um último vislumbre de pessoas prestes a desaparecer nos porões da escravidão (HARTMAN, 2008, p. 17).

A imagem ecoa o desconforto que acompanhava minha animação curiosa durante as pesquisas em arquivos para a biografia de Sueli Carneiro. Por vezes senti náuseas ao ler nomes e mais nomes de pessoas acompanhados da palavra "escrava" em livros pesados e amarelados de igrejas. Aquele amontoado de páginas e linhas e pó era o registro de corpos, pessoas, existências extremamente violentadas. Nós não temos a dimensão do que foi a escravização negra. Começamos a perceber que é imensa e realmente terrível quando reverbera no corpo. Para mim, mais que ouvir genericamente sobre as violações, remexer os arquivos com nome, características físicas, nome da mãe, local de nascimento trouxe materialidade. E também a esperança que, se todo mundo pudesse experimentar no corpo essa indignação, a compreensão do racismo como continuação e atualização desse passado próximo aumentaria. E também a resistência ao dispositivo de racialidade.

Saidiiya Hartman, além de pesquisar e escrever sobre o tráfico transatlântico, empreendeu o desafio de tentar trazer o passado para mais perto, e passou um ano em Gana, na África, pesquisando. Lá, ela se percebeu como relíquia de uma experiência que todos preferiam não lembrar; o lembrete de que 12 milhões de pessoas cruzaram o Atlântico no passado; descendente de cativos; vestígio da morte. (HARTMAN, 2008, p. 18).

Depois de um ano em Gana, mais do que encontrar o legado de reis e rainhas, encontrou a luta para permanecer de pé, escapar e derrotar a escravidão em todas as suas formas. Escolheu conectar-se com o sonho de um território livre. De autonomia, em vez de uma nacionalidade. Ao final do primoroso livro Lose your mother, Saidiya descreve a cena de quatro garotas pulando corda, cantando algo como:

Gwolu [a cidade em que estavam] é uma cidade de ouro

Quando você entra no círculo

Você será protegido

Você estará a salvo.

(HARTMAN, 2008. p. 235)

A música mencionava os que haviam sido vendidos como escravos. A cantiga infantil evocava a diáspora. E ali Saidiya encontrava sua música: a da tribo perdida. 
A proposição teórica de Saidiya Hartman é a fabulação crítica, definida por ela como um método que requer a re-montagem e re-apresentação dos "relatos autorizados" que constam nos arquivos. Com o método, realizou uma pesquisa sobre mulheres negras no século XIX publicadas no recém-lançado Wayward livres beautiful experimentes: intimate histories of riotous black girls, troublesome women, and queer radicals (2019). No livro, Saidiya faz uma ampla pesquisa de personagens que viveram em grandes cidades norteamericanas naquele período e recria as vozes dessas mulheres na tentativa de capturar a riqueza da vida social negra, esta, ausente dos arquivos.

Segundo a autora, todas as personagens, lugares e eventos foram coletados de jornais, pesquisas sociológicas, transcrições, fotografias, relatórios de investigação policial de profissionais da assistência social, entrevistas com psicólogos e psiquiatras e casos criminais. Nada foi inventado. Ao organizar uma narrativa pela tentativa de trazer a voz dessas personagens, uma história desconhecida do século XIX é contada e oferece detalhes de experiências de liberdade e radicalidade, segundo a autora, revolucionárias.

A fabulação crítica, ao re-trabalhar informações escavadas em diferentes arquivos, pode ser um recurso para tirar a escravização da categoria 'história assombrada', de Jenny Sharpe (2003). Quanto mais escrevermos sobre nosso passado, maior a possibilidade de histórias de racismo e violência deixarem de nos assombrar.

Apesar de nossa habilidade para analisar e criticar, a esquerda se enraizou naquilo que é. Nós frequentemente esquecemos de vislumbrar aquilo que pode vir a ser. Esquecemos de escavar o passado em busca de soluções que nos mostrem como podemos existir de outras formas no futuro (IMARISHA, 2016).

Para Walidah Imarisha, toda articulação política é ficção científica por ser baseada em sonhos coletivos de mundos que ainda não existem. A possibilidade imaginativa da ficção, segundo a autora, oferece aos movimentos sociais possibilidades para explorar a criação de novos mundos. "É por isso que a descolonização da imaginação é o mais perigoso e subversivo de todos os processos de descolonização". Reformas sutis no sistema existente, segundo Imarisha, são inefetivas e constituem barreiras que nos impedem de imaginar um mundo, por exemplo, sem justiça ou prisões.

Somos o sonho das gentes pretas escravizadas, a quem foi dito que seria 'irrealista' imaginar um dia em que elas não seriam chamadas propriedade. Essas pessoas Pretas recusaram a confinar seus sonhos ao realismo, e em vez disso elas nos sonharam. Assim elas curvaram a realidade, reformularam o mundo, para criar-nos (IMARISHA, 2016). 
Como no curso de um rio caudaloso, somos a continuidade da existência de nossos ancestrais, e por nós passa o fluxo que levará nossos descendentes ao futuro que sonhamos. Mote do poema Vozes-Mulheres, de Conceição Evaristo, escrito clássico de primordial importância na conexão de temporalidades.

\author{
A voz de minha bisavó \\ ecoou criança \\ nos porões do navio. \\ Ecoou lamentos \\ de uma infância perdida. \\ A voz de minha avó \\ ecoou obediência \\ aos brancos-donos de tudo.
}

A voz de minha mãe ecoou baixinho revolta no fundo das cozinhas alheias debaixo das trouxas roupagens sujas dos brancos pelo caminho empoeirado rumo à favela
A minha voz ainda ecoa versos perplexos com rimas de sangue e fome.

A voz de minha filha recolhe todas as nossas vozes recolhe em si as vozes mudas caladas engasgadas nas gargantas.

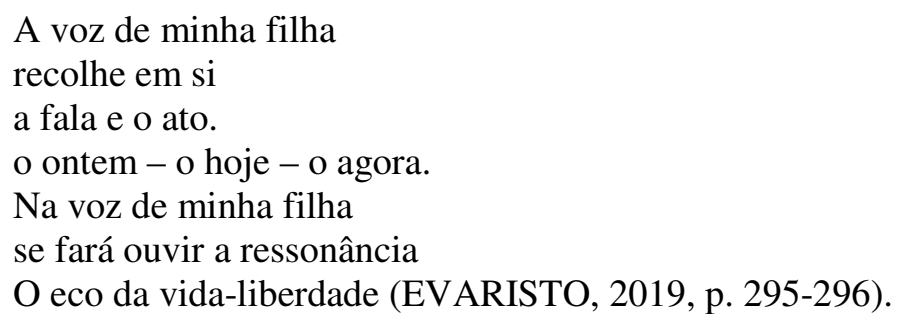

A palavra escrita como atributo do preexistente. $\mathrm{Na}$ intenção de interromper o racismo e o genocídio negro, mas na proposição de soluções coletivas para os problemas de pessoas negras e também de não-negras. Palavras que, como no Sankofa, têm no passado a principal referência e nele bebem a imaginação do porvir. Da voz de lamentos da bisavó ao eco da vida liberdade da filha. 


\section{CONSIDERAÇÕES FINAIS}

Para trabalhar a hipótese de que a escrita de si de mulheres negras, pela formulação estética de sua própria existência e trabalho de memória, possibilita a constituição de subjetividades e de sujeitos coletivos que permitem resistir ao racismo, foram analisados nesta tese fragmentos de textos selecionados em dois conjuntos: clássicos e táticos.

Os fragmentos foram categorizados e analisados em sete eixos e, nomeá-los mais uma vez, ajuda a explicitar o que caracteriza, nesta tese, a resistência de mulheres negras ao racismo: sobrevivência física, preservação da saúde e da capacidade cognitiva; elaboração de traumas; organização de sujeitos coletivos; crítica aos processos de exclusão racial, social e de gênero; ruptura com a subordinação e a subalternização aos discursos de dominação racial, de gênero e social; olhar a partir de uma perspectiva própria; proposição de caminhos de emancipação individual e coletiva.

Este trabalho buscou também refletir sobre um conjunto de questões referenciadas a diferentes campos do conhecimento, mas conexas entre si, tendo, como articulação, as mulheres negras - sua história, suas memórias, sua identidade cultural.

Para construir tal mosaico, muitas peças foram necessárias. Refletir sobre memória, sobre informação, sobre documentos. Refletir acerca dos diversos tipos de suporte, de documentos e de suas fontes. Articular os territórios da História, da Ciência da Informação, da Antropologia, da Filosofia.

Em relação aos documentos, a trajetória dessa pesquisa contribui para problematizar e refletir acerca de seu status e definição. Foram trabalhados como documentos materiais oriundos de diversas fontes, com distintas características: estudos históricos, documentos legais, peças literárias, memórias. Em relação a estas últimas, os documentos relacionados revelaram-se criaturas híbridas, construídas no decorrer da pesquisa. Como pesquisadora, exerci, portanto, um trabalho misto: co-produtora de documentos; organizadora; analista; leitora. E tudo se fez necessário em função do que se buscava levantar e entender. Trabalhar com memórias, identidades, escrita de si, significa deambular, não se fixar em um formato ou uma atividade unívoca, definida e delimitada.

Tal análise permite afirmar que a escrita de si de mulheres negras é um instrumento de produção e circulação de informação e conhecimento, técnica de pesquisa e tecnologia individual e coletiva de resistência ao racismo. 
Não estava nas intenções iniciais, mas, ao longo da escrita deste trabalho, acabei, eu mesma, por praticar a escrita de si, ao compartilhar memórias e escrevivências que se conectavam à articulação teórica e aos textos analisados.

Mulheres negras foram apresentadas como as pretas e pardas que, a partir de memórias coletivas, histórias e repertórios culturais comuns, se colocam como sujeito político insurgente frente às discriminações de raça, gênero e classe. A anterioridade, assim nomeada por Jurema Werneck, foi exercitada na apresentação de referenciais historiográficos e mitológicos africanos, destacadamente iorubanos e bantus, indicando que a história de mulheres negras brasileiras começa há muitos séculos, e carrega valores comunitários e ancestrais.

Apesar da importância de se afirmar a anterioridade, é inegável que as trajetórias diversas dessas mulheres negras, muito diferentes entre si, foram marcadas, como sujeito coletivo, pela travessia do tráfico negreiro e da escravização de negras e negros. Por isso, foi feito o exercício proposto por Abdias Nascimento (2019) de percorrer os detalhes deste passado que é também de resistência, com a intenção de conhecer e nos apropriarmos de um potencial de luta libertária.

Foram apresentados inúmeros casos exemplares de como o dispositivo de racialidade, com seus ditos e não ditos presentes nos discursos, instituições, arquiteturas, e biopoder configuram o racismo no Brasil, produzindo um sistema de supremacia - para o Ser - e subordinação racial - para os Outros. Foram descritos casos em que o biopoder, ao acionar o dispositivo de racialidade, explicitamente fez viver o Ser e deixou morrer o Outro.

Mas, como qualquer dispositivo, o de racialidade e o biopoder geram resistência. E nesta tese, a escrita de si de mulheres negras, como técnica de si e estética da existência, foi analisada como possibilidade de resistência ao racismo. Tanto na escrita em si, como no conteúdo escrito por essas mulheres, testemunhos das discriminações, mas também das práticas de resistência.

A memória, compreendida nesta tese tanto como atividade de lembrar na imagemmemória quanto nos modos de ser e fazer na memória-hábito, se realiza no indivíduo e compõe uma memória coletiva. É o fio que conecta temporalidades, compartilhado em diferentes linguagens, conteúdo da escrita de si. Memória como o que se sente e se expressa de cor, do coração. Na vibração da anterioriedade e do devir no presente próprio de uma perspectiva afro-centrada vivenciada e difundida por mulheres negras. Memória para 
conectar à ancestralidade e guiar o caminho, em uma combinação de temporalidades característica de um estar-mundo do sujeito político mulher negra.

Desta escrita de memória podem nascer possibilidade de futuro para todas e todos, em que mulheres negras, com a visão ampliada a partir da base da pirâmide para toda sociedade, possam viver livres do racismo, do sexismo e da desigualdade.

$\mathrm{Na}$ escrita das conclusões desta tese, recebi, no grupo de WhatsApp da UNEafro, vídeos de coordenadoras e coordenadores de núcleos de cursinhos comunitários no quilombo Ivaporunduva, no Vale do Ribeira, estado de São Paulo. Em círculo, de mãos dadas, com os pés no correr do rio, Elaine Mineiro, da Cidade Tiradentes, coordenadora do núcleo no Jardim Pantanal, na Zona Leste de São Paulo, e Wellington Otimista, coordenador do núcleo de Poá, região metropolitana de São Paulo, falam sobre se sentir em casa e sobre o modo de vida construído por nossos ancestrais, que nada tem a ver com a violência a que negras e negros são submetidos diariamente no capitalismo.

Imagem 15: Militantes da UNEafro Brasil no rio Ribeira, Quilombo Ivaporunduva

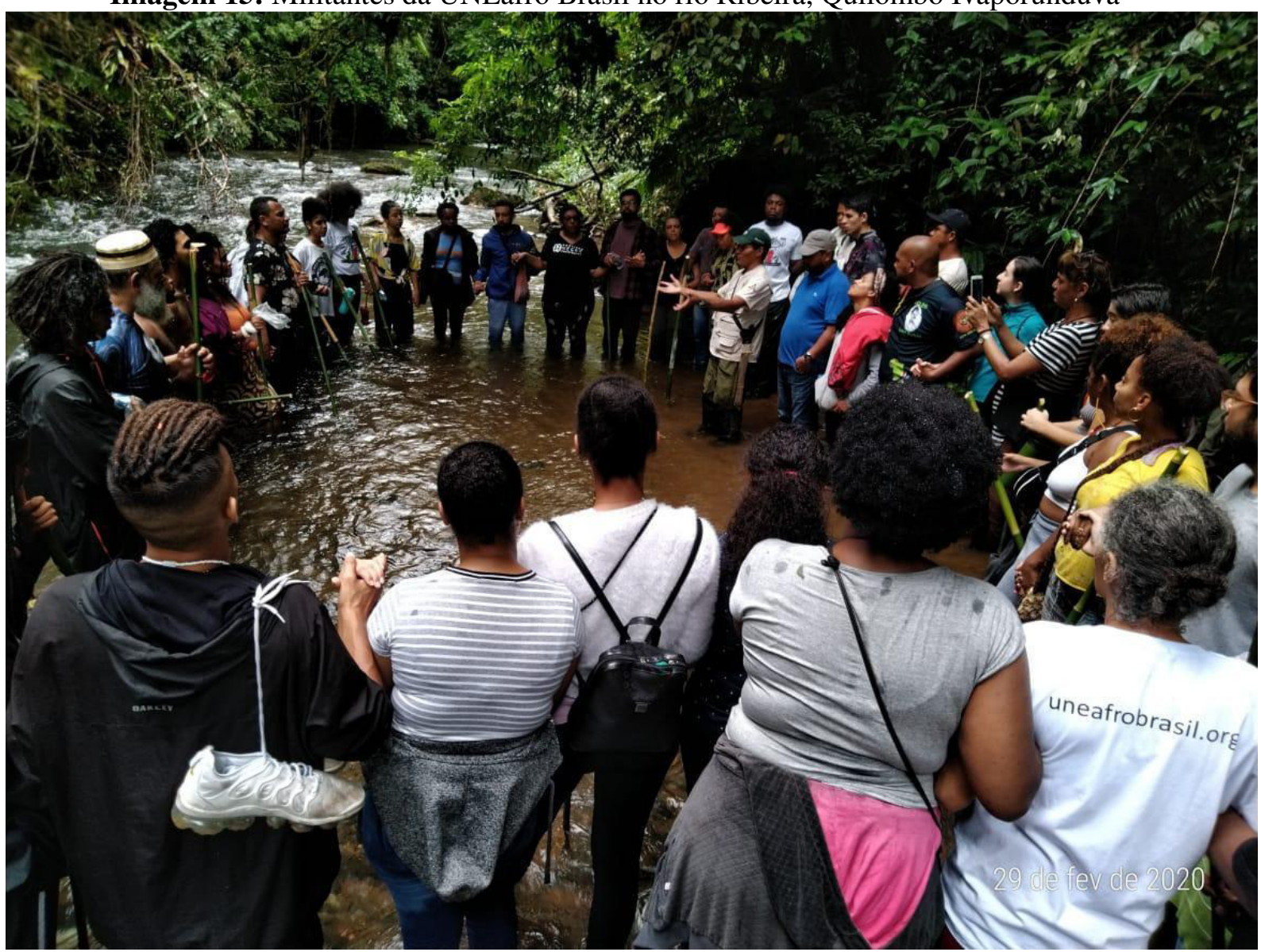

Fonte: grupo de WhatsApp da UNEafro / Foto de Douglas Belchior 
Emocionada, tive a certeza de que muitas e muitos dos meus contemporâneos, estamos conectados e atentos aos planos feitos pelos que vieram antes de nós. Em um senso ampliado de comunidade, estamos realizando aquilo que nossos ancestrais desenharam como projeto de resistência à escravidão e ao racismo e, ainda mais importante, projeto de existência compartilhada, em conexão com a natureza e a espiritualidade.

Não acredito que algum de nós vai viver a sociedade justa, igualitária e livre do racismo, do sexismo e das desigualdades sociais. Mas cada ação que concretizamos hoje, pavimenta o caminho para este porvir. Em 200 anos, quando a estrutura social brasileira estiver liberta do fardo que a escravidão manifesta como racismo em 2020, seremos lembradas e lembrados como os ancestrais que contribuíram com este caminho.

$\mathrm{Na}$ formulação teórica, na escrita de si, na organização política que mina, pelas frestas, o dispositivo de racialidade e o biopoder. Palmares existiu e nos prova que a liberdade para negras e negros - em comunhão com indígenas e não-negros que nos reconheçam como Ser, sem nos inferiorizar como Outro - é possível.

Faremos Palmares de Novo! 


\section{REFERÊNCIAS BIBLIOGRÁFICAS}

ACOSTA, Alberto. O bem viver: uma oportunidade para imaginar outros mundos. Elefante, 2016.

ADICHIE, Chimamanda Ngozi. Americanah. São Paulo: Companhia das Letras, 2014.

AGUIAR, Gilberto Orácio. Mulheres negras da montanha: as benzedeiras de Rio de Contas, Bahia, na recuperação da saúde. 2009. Disponível em:

$<\mathrm{https}$ ://ciberteologia.com.br/assets/pdf/post/mulheres-negras-da-montanha-as-benzedeirasde-rio-de-contas-bahia-na-recuperacao-da-saude.pdf $>$.

AGUIAR, Marli de Fátima. Sementes espalhadas que florescem. In: SANTANA, Bianca. Inovação ancestral de mulheres negras: táticas e políticas do cotidiano. São Paulo: Oralituras, 2019.

AGUIAR, Marli de Fátima. Tecendo memórias e histórias. São Paulo, 2016.

ALMA PRETA. Segundo Ministério da Saúde, 62,8\% das mulheres mortas durante o parto são negras. Disponível em: <https://www.almapreta.com/editorias/realidade/segundoministerio-da-saude-62-8-das-mulheres-mortas-durante-o-parto-sao-negras $>$.

ALMEIDA, Marco Antônio de. Literatura, informação, conhecimento e ciência: considerações a partir da literatura policial. In: (org.). Ciência da informação e literatura. Campinas: Editora Alínea, 2012.

A cada leitor seu texto: dos livros às redes. Encontros Bibli, Florianópolis, n. esp, v. 1, p. 154-173, 2009a.

Informação, tecnologia e mediações culturais. Perspectivas em Ciência da

Informação, v. 14, n. spe, p. 184-200, 2009b. Disponível em:

$<$ http://www.scielo.br/scielo.php?script=sci_arttext\&pid=S1413-

99362009000400013\&lng=en\&nrm=iso >. Acesso em: 10 jan. 2018.

Mediação e mediadores nos fluxos tecnoculturais contemporâneos. Informação \& Informação, [S.1.], v. 19, n. 2, p. 191-214, out. 2014. ISSN 1981-8920. Disponível em: <http://www.uel.br/revistas/uel/index.php/informacao/article/view/20000>.

ALVES, Miriam. Brasilafro autorrevelado: literatura brasileira contemporânea. Nandyala Livraria Editora, 2010.

A LITERATURA NEGRA FEMININA NO BRASIL - PENSANDO A EXISTÊNCIA. Revista da Associação Brasileira de Pesquisadores/as Negros/as (ABPN), [S.1.], v. 1, n. 3, p. 181-190, fev. 2011. ISSN 2177-2770. Disponível em: $<$ http://www.abpnrevista.org.br/revista/index.php/revistaabpn1/article/view/280>. Acesso em: 05 jan. 2018.

ARAUJO, José do Carmo. Sociedades \& Raça: A África e os Povos Bantos. 2015 
ASANTE, Molefi Kete. Afrocentricity. John Wiley \& Sons, Inc., 2009.

ASSIS DUARTE, Eduardo de. Machado de Assis afro-descendente. Rio de Janeiro: Pallas, 2007.

Literatura afro-brasileira: um conceito em construção. Estudos de literatura brasileira contemporânea, n. 31, 2008.

Mulheres marcadas: literatura, gênero, etnicidade. Terra Roxa e Outras Terras:

Revista de Estudos Literários, v. 17, n. 1, p. 6-18, 2009.

ASSIS DUARTE, Eduardo; FONSECA, Maria Nazareth Soares; DE GODOY, Maria Carolina. Literatura e afrodescendência no Brasil: antologia crítica. Editora UFMG, 2011.

ASSMANN, Aleida. Espaços da recordação: formas e transformações da memória cultural. Editora da Unicamp, 2011.

AZEVEDO, Vanda Alves Torres. Símbolo ancestral feminino no Brasil. 2006. Tese de Doutorado. Pontifícia Universidade Católica de São Paulo.

BAHIA, Silvana. Poder ser, existir e escolher. In: SANTANA, Bianca. Inovação ancestral de mulheres negras: táticas e políticas do cotidiano. São Paulo: Oralituras, 2019.

BAIRROS, Luiza. Lembrando Lélia Gonzalez. In. WERNECK, Jurema; MENDONÇA, Maisa e WHITE, Evelyn C. O livro da saúde das mulheres negras - nossos passos vêm de longe. Rio de Janeiro: Criola/Pallas, 2000.

. Nossos feminismos revisitados. Estudos feministas, v. 3, n. 2, p. 458, 1995. In:

SANTANA, Bianca. Vozes insurgentes de mulheres negras: do século 18 à primeira década do século 21. Belo Horizonte: Mazza Edições, 2019.

BARRETO, Aldo de Albuquerque. A questão da informação. São Paulo em Perspectiva, v. 8, n. 4, p. 3-8, 1994.

BARRETO, Lima. Diário íntimo: memórias. Editora Brasiliense, 1961. Disponível em: $<$ http://www.dominiopublico.gov.br/pesquisa/DetalheObraForm.do?select_action=\&co_ob ra $=2078>$. Acesso em 29 de maio de 2018.

BARRETO, Raquel de Andrade. Enegrecendo o feminismo ou Feminizando a raça: narrativas de libertação em Angela Davis e Lélia Gonzáles. Rio de Janeiro: PUC-Rio, Departamento de História, 2005.

Lélia Gonzalez, uma intérprete do Brasil. In: GONZALEZ, Lélia. Primavera para as rosas negras. São Paulo: Diáspora Africana, 2018.

BARROS, Antonieta. Bilhete sem sê-lo. In: SANTANA, Bianca. Vozes insurgentes de mulheres negras: do século 18 à primeira década do século 21. Belo Horizonte: Mazza Edições, 2019. 
BARROS, Dirlene Santos; AMÉLIA, Dulce. Arquivo e memória: uma relação indissociável. Transinformação, v. 21, n. 1, p. 55-61, 2009.

BAYO, Luana. Mulher negras: uma vida entre o sonho e a realidade. In: SANTANA, Bianca. Inovação ancestral de mulheres negras: táticas e políticas do cotidiano. São Paulo: Oralituras, 2019.

BELI, Beth. Sobre mim e sobre nós!. In: SANTANA, Bianca. Inovação ancestral de mulheres negras: táticas e políticas do cotidiano. São Paulo: Oralituras, 2019.

BENJAMIN, Walter. O Narrador. São Paulo: Abril Cultural, 1980.

Escavando e recordando. In: Obras escolhidas vol. III - Rua de mão única. São Paulo: Brasiliense, 1987.

BENTES, Nilma. Brasil - Durban - Brasil: um marco na luta contra o racismo. In: SANTANA, Bianca. Vozes insurgentes de mulheres negras: do século 18 à primeira década do século 21. Belo Horizonte: Mazza Edições, 2019.

BENTO, Cida. Branquitude e poder - a questão das cotas para negros. In: SANTANA, Bianca. Vozes insurgentes de mulheres negras: do século 18 à primeira década do século 21. Belo Horizonte: Mazza Edições, 2019.

BENTO, Luciana. Mulher preta trabalha. In: SANTANA, Bianca. Inovação ancestral de mulheres negras: táticas e políticas do cotidiano. São Paulo: Oralituras, 2019.

BERND, Zilá. Em busca dos rastros perdidos da memória ancestral: um estudo de Um defeito de cor, de Ana Maria Gonçalves. Estudos de literatura brasileira contemporânea, n. 40, 2012.

BERNARDINO-COSTA, Joaze. Decolonialidade e interseccionalidade emancipadora: a organização política das trabalhadoras domésticas no Brasil. Sociedade e Estado, v. 30, n. 1, p. 147-163, 2015.

BEZERRA, Kátia. Cyana Leahy-Dios. In: DUARTE, Eduardo de Assis (org.). Literatura e afrodescendência no Brasil: antologia crítica. Volume 2: consolidação. Belo Horizonte: Editora UFMG, 2011.

BONFIM, Vânia Maria da Silva. A identidade contraditória da mulher negra brasileira: bases históricas. Sankofa volume 4: Afrocentricidade - Uma abordagem epistemológica inovadora, 2009, p. 219-249.

BOSI, Ecléa. O tempo vivo da memória: ensaios de psicologia social. São Paulo: Ateliê Editorial, 2003. 1994.

Memória e sociedade: lembranças de velhos. São Paulo: Companhia das Letras, 
BRANDÃO, Leci. Marias. In: SANTANA, Bianca. Vozes insurgentes de mulheres negras: do século 18 à primeira década do século 21. Belo Horizonte: Mazza Edições, 2019.

CALDWELL, Kia Lilly. Fronteiras da diferença: raça e mulher no Brasil. Estudos feministas, 2000, p. 91-108.

CAPURRO, R. Epistemologia e Ciência da Informação. 2003. Disponível em: $<$ http://www.capurro.de/enancib_p.htm>.

CARNEIRO, Fernanda. Nossos passos vêm de longe... In: WERNECK, J. MENDONÇA, M. WHITE, E. O livro da saúde das mulheres negras: nossos passos vêm de longe. Rio de Janeiro: Pallas/ Criola, 2006.

CARNEIRO, Fernanda (org.). Quem Meus Filhos Beija Minha Boca Adoça. Carneiros da Maria Camila e Domiciano. Ubá, 2001.

CARNEIRO, Sueli. A construção do outro como não-ser como fundamento do ser. 2005. Tese de Doutorado. FE-USP, 2005.

Aliança de Parentesco. Geledés, 2004. Disponível em:

$<$ https://www.geledes.org.br/alianca-de-parentesco $>$.

Enegrecer o feminismo: a situação da mulher negra na América Latina a partir de uma perspectiva de gênero. In: ASHOKA EMPREENDIMENTOS SOCIAIS; TAKANO CIDADANIA (org.). Racismos contemporâneos. Rio de Janeiro: Takano Ed., 2003.

Gênero Raça e Ascensão Social. Estudos Feministas, v. 3, n. 2, p. 544, 1995.

Matriarcado da miséria. Correio Braziliense, p. 5, 2000. Disponível em:

$<$ https://www.geledes.org.br/o-matriarcado-da-miseria $>$.

Mulheres em movimento. In: SANTANA, Bianca. Vozes insurgentes de mulheres negras: do século 18 à primeira década do século 21. Belo Horizonte: Mazza Edições, 2019.

CARNEIRO, Sueli; CURY, Cristiane. O candomblé. In: NASCIMENTO, Elisa Larkin (Ed.). Guerreiras de Natureza: mulher negra, religiosidade e ambiente. Grupo Editorial Summus, 2008a.

O poder feminino no culto aos orixás. In: NASCIMENTO, Elisa Larkin (Ed.).

Guerreiras de Natureza: mulher negra, religiosidade e ambiente. Grupo Editorial Summus, 2008b.

CARRIL, Lourdes. Quilombo, favela e periferia: a longa busca da cidadania. Annablume, 2006.

CÉSAIRE, Aimé. Discurso sobre o colonialismo. Florianópolis: Letras Contemporâneas, 2010. 
CRIPPA, Giulia. Tecendo tramas literárias para uma narrativa da memória. In: ALMEIDA, Marco Antônio de (org.). Ciência da informação e literatura. Campinas: Editora Alínea, 2012.

CASTRO FARIA, Sheila. Mulheres forras-riqueza e estigma social. Tempo, n. 9, p. 65-92, 2000.

COR, Ariane. Hospitalidade radical para futuros feministas. In: SANTANA, Bianca. Inovação ancestral de mulheres negras: táticas e políticas do cotidiano. São Paulo: Oralituras: 2019.

CRUZ, Tereza Almeida. Um Estudo comparado das relações ambientais de mulheres da floresta do Vale do Guaporé (Brasil) e do Mayombe (Angola) - 1980 - 2010. Tese (doutorado) - Universidade Federal de Santa Catarina, Centro de Filosofia e Ciências Humanas. Programa de Pós-Graduação em História, 2012. Disponível em: <https://repositorio.ufsc.br/xmlui/handle/123456789/96390>. Acesso em julho de 2016.

CUNHA, Eunice. Apelo às mulheres negras. In: SANTANA, Bianca. Vozes insurgentes de mulheres negras: do século 18 à primeira década do século 21. Belo Horizonte: Mazza Edições, 2019.

CUTI. Libertas entre contratos e aluguéis: trabalho doméstico em São Paulo às vésperas da abolição. In: MACHADO, Maria Helena Pereira Toledo; CASTILHO, Celso Thomas (Ed.). Tornando-se livre: agentes históricos e lutas sociais no processo de Abolição. EDUSP, 2015.

Literatura negro-brasileira. Selo Negro Edições, 2010.

DAIBERT, Robert. A religião dos bantos: novas leituras sobre o calundu no Brasil colonial. Estudos Históricos (Rio de Janeiro), v. 28, n. 55, p. 7-25, 2015.

DALCASTAGNÈ, Regina. A personagem do romance brasileiro contemporâneo: 19902004. Estudos de Literatura Brasileira Contemporânea, 2005. Disponível em: <http://www.redalyc.org/articulo.oa?id=323127089002>.

Entre silêncios e estereótipos: relações raciais na literatura brasileira contemporânea. Estudos de literatura brasileira contemporânea, n. 31, 2008a.

Literatura brasileira contemporânea: um território contestado. São Paulo: Horizonte, 2017.

Vozes nas sombras: representação e legitimidade na narrativa contemporânea. Ver e imaginar o outro: alteridade, desigualdade, violência na literatura brasileira contemporânea. São Paulo: Horizonte, 2008b, p. 78-107.

DAMACENO, Janaína. Os segredos de Virgínia: estudo de atitudes e preconceitos de cor na São Paulo dos anos 1940-1950. In: CHALHOUB, Sidney e PINTO, Ana Flávia Magalhães. Pensadores negros - pensadoras negras: Brasil séculos XIX e XX. Belo Horizonte: Fino Traço, 2016. 
DEE, Lara. Empreendedora Lara Dee. In: SANTANA, Bianca. Inovação ancestral de mulheres negras: táticas e políticas do cotidiano. São Paulo: Oralituras, 2019.

DIAS, Cleo. Grão de café. In: SANTANA, Bianca. Inovação ancestral de mulheres negras: táticas e políticas do cotidiano. São Paulo: Oralituras, 2019.

DIOGO, Luciana Martins. Da sujeição à subjetivação: a literatura como espaço de construção da subjetividade, os casos das obras Úrsula e A Escrava de Maria Firmina dos Reis. Tese de Doutorado. Universidade de São Paulo, 2016.

O DIREITO. Revista de legislação, doutrina e jurisprudência. Ano II-1874. Rio de Janeiro: João José do Monte Junior.

DUARTE, Constância Lima. Cidinha da Silva. In: DUARTE, Eduardo de Assis (org.). Literatura e afrodescendência no Brasil: antologia crítica. Volume 4: contemporaneidade. Belo Horizonte: Editora UFMG, 2011.

DUDA, Nega. Não tem coisa boa se não lembra da ruim. In: SANTANA, Bianca. Inovação ancestral de mulheres negras: táticas e políticas do cotidiano. São Paulo: Oralituras, 2019.

ELTIS, David; RICHARDSON, David. The Trans-Atlantic Slave Trade Database Voyages. Emory University: Digital Library Research Initiative, 2010. Disponível em: $<$ http://www.slavevoyages.org $>$.

ESSED, Philomena. Understanding everyday racism: An interdisciplinary theory. Sage, 1991.

EVARISTO, Conceição. Carolina Maria de Jesus: como gritar no Quarto de despejo que "black is beautiful"? In: CHALHOUB, Sidney e PINTO, Ana Flávia Magalhães.

Pensadores negros - pensadoras negras: Brasil séculos XIX e XX. Belo Horizonte: Fino Traço, 2016.

Gênero e etnia: uma escre (vivência) de dupla face. In: MOREIRA, Nadilza de Barros; SCHNEIDER, Liane (orgs.). Mulheres no mundo: etnia, marginalidade e diáspora. João Pessoa: Idéia, 2005. Disponível em:

$<$ http://nossaescrevivencia.blogspot.com/2012/08/genero-e-etnia-uma-escrevivenciade.html>.

Vozes-mulheres. In: SANTANA, Bianca. Vozes insurgentes de mulheres negras: do século 18 à primeira década do século 21. Belo Horizonte: Mazza Edições, 2019.

FANON, Frantz. Pele negra, máscaras brancas. SciELO-EDUFBA, 2008.

FARIAS, Juliana Barreto. Mercados Minas: africanos ocidentais na Praça do Mercado do Rio de Janeiro (1830-1890). 2012. Tese de Doutorado. Universidade de São Paulo. 
FAUSTINO, Carmen. Mulheres negras sempre em roda - isso não é uma ficção! In: SANTANA, Bianca. Inovação ancestral de mulheres negras: táticas e políticas do cotidiano. São Paulo: Oralituras: 2019.

FAUSTO, Boris; História do Brasil. São Paulo: Edusp, 1997.

FERRARO, Alceu Ravanello. Alfabetização Rural no Brasil na Perspectiva das Relações Campo-Cidade e de Gênero. Educação \& Realidade, v. 37, n. 3, p. 943-967, 2012.

FERRARO, Alceu Ravanello; KREIDLOW, Daniel. Analfabetismo no Brasil: configuração e gênese das desigualdades regionais. Educação \& Realidade, v. 29, n. 2, 2004.

FERREIRA, Vera Lúcia da Silva Sales Ferreira. Cristiane Sobral. In: DUARTE, Eduardo de Assis (org.). Literatura e afrodescendência no Brasil: antologia crítica. Volume 4: contemporaneidade. Belo Horizonte: Editora UFMG, 2011.

FONSECA, Maria Nazareth Soares. Poemas da recordação e outros movimentos. Nandyala, 2008.

Posfácio: costurando uma colcha de memórias. In: EVARISTO, Conceição. Becos da memória. Florianópolis: Editora Mulheres, 2013.

FOUCAULT, Michel. A escrita de si. In: O que é um autor? Lisboa: Passagens. 1992. p. 129-160. Disponível em: <http://eps.otics.org/material/entrada-outras-ofertas/livros/aescrita-de-si-michel-foucault $>$.

FOUCAULT, Michel; DELEUZE, Gilles. Os intelectuais e o poder. Microfísica do poder, v. 17, p. 69-78, 1979.

FREITAS, Maitê. Se o caminho é meu... In: SANTANA, Bianca. Inovação ancestral de mulheres negras: táticas e políticas do cotidiano. São Paulo: Oralituras, 2019.

FROHMANN, B. Revisiting "What is a document?". Journal of Documentation, v.66, n.2,

p.291-303, 2009.

O caráter social, material e público da informação. In: A dimensão

epistemológica da Informação e suas interfaces técnicas, políticas e institucionais nos processos de produção, acesso e disseminação da informação. Orgs: Mariângela Spotti Lopes Fujita, Regina Maria Marteleto e Marilda Lopes Ginez de Lara. São Paulo: Cultura Acadêmica; Marília: Fundepe, 2013.

FU-KIAU, Kimbwandende Kia Bunseki. African cosmology of the Bântu-Kôngo: tying the spiritual knot: Principles of life \& living. African Tree Press, 2001.

GAGNEBIN, Jeanne-Marie. História e narração em Walter Benjamin. Ed. Perspectiva, 1999. 
O que significa elaborar o passado? In:

Lembrar, esquecer, escrever.

São Paulo: editora 34, 2018, p. 97-105.

GARCIA, Esperança. Carta. In: SANTANA, Bianca. Vozes insurgentes de mulheres negras: do século 18 à primeira década do século 21. Belo Horizonte: Mazza Edições, 2019.

GONÇALVES, Ana Beatriz Rodrigues. Sônia Fátima da Conceição. In: DUARTE, Eduardo de Assis (org.). Literatura e afrodescendência no Brasil: antologia crítica. Volume 4: contemporaneidade. Belo Horizonte: Editora UFMG, 2011.

GONÇALVES, Ana Maria. Um defeito de cor. Rio de Janeiro: Record, 2009.

GONZALEZ, Lélia. Cultura, Etnicidade e Trabalho: Efeitos Lingüísticos e Políticos da Exploração da Mulher. Comunicação apresentada no $8^{\circ}$ Encontro Nacional da Latin American Studies Association Pittsburgh, 5 a 7 de abril de 1979. Disponível em: $<$ https://coletivomariasbaderna.files.wordpress.com/2012/09/cultura_etnicidade_e_trabalho .pdf>.

Mulher Negra. In: NASCIMENTO, Elisa Larkin (Ed.). Guerreiras de Natureza: mulher negra, religiosidade e ambiente. Grupo Editorial Summus, 2008.

Democracia racial? Nada disso! In: Jornal Mulherio, a. 1, n. 4, São Paulo: Mulherio, nov./dez, 1981.

. Por un feminismo afrolatinoamericano. 1988.

Primavera para as rosas negras. São Paulo: Diáspora Africana, 2018.

Racismo e sexismo na cultura brasileira. In: SANTANA, Bianca. Vozes

insurgentes de mulheres negras: do século 18 à primeira década do século 21 . Belo Horizonte: Mazza Edições, 2019.

HALL, Stuart. Da diáspora: identidades e mediações culturais. Editora UFMG, 2006.

A centralidade da cultura: notas sobre as revoluções culturais do nosso tempo.

Educação \& Realidade, Porto Alegre, v. 22, n2, p. 15-46, jul. dez., 1997.

Quem precisa de identidade. Identidade e diferença: a perspectiva dos estudos culturais. Petrópolis: Vozes, 2000, p. 103-133.

HARTMAN, Saidiya. Lose your mother: A journey along the Atlantic slave route. Macmillan, 2008.

HIRSCHMAN, Sarah. Gente y cuentos.; A quién pertenece la literatura?: las comunidades encuentran su voz a través de los cuentos. Fondo de Cultura Económica, 2011.

hooks, bell. Ensinando a transgredir: a educação como prática da liberdade. São Paulo: Editora WMF Martins Fontes, 2013. 
Elefante, 2018.

Erguer a voz: pensar como feminista, pensar como negra. São Paulo: Editora

. Olhares negros: raça e representação. Tradução de Stephanie Borges. São Paulo: Elefante, 2019.

. Alisando o nosso cabelo. Revista Gazeta de Cuba - Unión de escritores y artista de Cuba, p. 01, 2005.

IMARISHA, Walidah. Reescrevendo o futuro: usando ficção científica para rever a justiça. São Paulo: Oficina de Imaginação Política - 32a Bienal, 2016.

IPEA. Dossiê Mulheres Negras: retrato das condições de vida das mulheres negras no Brasil, Brasília, 2013.

Retrato das Desigualdades Gênero e Raça. Brasília, 2011.

JARDIM, José Maria; FONSECA, Odila Maria. A invenção da memória nos arquivos públicos. Ciência da Informação, v. 25, n. 2, p. 1-13, 1995.

JESUS, Carolina Maria de. Trechos do livro Quarto de despejo: diário de uma favelada. In: SANTANA, Bianca. Vozes insurgentes de mulheres negras: do século 18 à primeira década do século 21. Belo Horizonte: Mazza Edições, 2019.

KAMITA, Rosana Cássia. Francisca Souza da Silva. In: DUARTE, Eduardo de Assis (org.). Literatura e afrodescendência no Brasil: antologia crítica. Volume 2: consolidação. Belo Horizonte: Editora UFMG, 2011.

. Laura Santos. In: DUARTE, Eduardo de Assis (org.). Literatura e afrodescendência no Brasil: antologia crítica. Volume 1: precursores. Belo Horizonte: Editora UFMG, 2011.

KILOMBA, Grada. Memórias da plantação. Rio de Janeiro: Cobogó, 2019.

LAGO, Luiz Aranha Corrêa. Da escravidão ao trabalho livre: Brasil, 1550-1900. Editora Companhia das Letras, 2014.

LANG, Miriam et al. Descolonizar o imaginário: debates sobre pós-extrativismo e alternativas ao desenvolvimento. São Paulo: Fundação Rosa Luxemburgo, 2016.

LARA, Dona Ivone. Alguém me avisou. In: SANTANA, Bianca. Vozes insurgentes de mulheres negras: do século 18 à primeira década do século 21. Belo Horizonte: Mazza Edições, 2019.

LARA, M. L. G. Informação, informatividade e lingüística documentária: alguns paralelos com reflexões de Hjorland e Capurro. DataGramaZero - Revista de Ciência da Informação, Rio de Janeiro, v. 9, n. 6, dez. 2008. Disponível em: $<$ http://dgz.org.Br/dez08/Art_01.htm>. 
LATOUR, B. Redes que a razão desconhece: laboratórios, bibliotecas, coleções. In:

BARATIN, Marc e Jacob, Christian (orgs.). O poder das Bibliotecas - A memória dos livros no Ocidente. Rio de Janeiro: UFRJ, 2000.

LEITE, José Correia et al. ...E disse o velho militante José Correia Leite. Secretaria Municipal de Cultura, 1992.

LIMA, G. dos S.; KROEFF, Márcia Silveira; RIBEIRO JUNIOR, Divino Ignácio. Tesauro afro-brasileiro: uso estratégico para organização e recuperação de informação.

ENCONTRO NACIONAL DE PESQUISA EM CIÊNCIA DA INFORMAÇÃO (ENANCIB), v. 15, p. 27-31, 2014.

LIMA, Izabel França de et al. Memória da população negra e informação étnico-racial: percebendo limites. 2017.

LOPES, Nei. Dicionário literário afro-brasileiro. Rio de Janeiro: Pallas, 2011.

Enciclopédia brasileira da diáspora africana. Selo Negro Edições, 2014.

LUCINDA, Elisa. Mulata exportação. In: SANTANA, Bianca. Vozes insurgentes de mulheres negras: do século 18 à primeira década do século 21. Belo Horizonte: Mazza Edições, 2019.

MACHADO, Maria Helena P. T. Entre dois Beneditos: histórias de amas de leite no ocaso da escravidão. In: XAVIER, Giovana; FARIAS, Juliana Barreto; DOS SANTOS GOMES, Flávio (Ed.). Mulheres negras no Brasil escravista e do pós-emancipação. São Paulo: Selo Negro Edições, 2012.

MACHADO, Veridiana Silva. O cajado de Lemba: o tempo no candomblé de nação Angola. 2015. Tese de Doutorado. Universidade de São Paulo.

MAKENA, Lucia. Resistência, luta e conquista. In: SANTANA, Bianca. Inovação ancestral de mulheres negras: táticas e políticas do cotidiano. São Paulo: Oralituras, 2019.

MARÇAL, Débora. Retalhos de Maria. In: SANTANA, Bianca. Inovação ancestral de mulheres negras: táticas e políticas do cotidiano. São Paulo: Oralituras, 2019.

MARCHA DAS MULHERES NEGRAS. Manifesto contra o racismo e a violência e pelo bem viver. Brasília, 2015.

MANIFESTO PELO DIA INTERNACIONAL DA MULHER NEGRA. Construindo a nossa história com autonomia. 2016. Disponível em:

$<$ http://www.marchamundialdasmulheres.org.br/wp-content/uploads/2016/07/Manifestodo-25-de-Julho.pdf>. Acesso em: julho de 2016.

MARCONDES, Mariana Mazzini et al. Dossiê mulheres negras: retrato das condições de vida das mulheres negras no Brasil. 2013. Disponível em:

$<$ http://repositorio.ipea.gov.br/bitstream/11058/3039/1/Livro- 
Dossi\%c3\%aa_mulheres_negras-

retrato_das_condi\%c3\%a7\%c3\%b5es_de_vida_das_mulheres_negras_no_Brasil >.

MARIANO, Silvana Aparecida; DOS SANTOS MACÊDO, Márcia. Desigualdades e interseccionalidades: deslindando a complexa trama das hierarquias e agenciamentos. Mediações-Revista de Ciências Sociais, v. 20, n. 2, p. 11-26, 2015.

MARQUES, Francisca Helena; PINTO, Tiago de Oliveira. Festa da Boa Morte e glória: ritual, música e performance. 2009.Universidade de São Paulo, São Paulo, 2009.

Disponível em: < http://www.teses.usp.br/teses/disponiveis/8/8134/tde-19022010-174044/ $>$.

MARTINS, Alaerte. Entrevista a Conceição Leme, no Portal Geledés. Disponível em: $<$ https://www.geledes.org.br/alaerte-martins-a-morte-materna-invisivel-das-mulheresnegras $>$.

MARTINS, Leda Maria. Afrografias da memória: o Reinado do Rosário no Jatobá. Mazza Edições, 1997.

MARTINS, Roberto Borges. Minas e o tráfico de escravos no século XIX, outra vez. Universidade Federal de Minas Gerais, Faculdade de Ciências Econômicas, Centro de Desenvolvimento e Planejamento [sic] Regional, 1994.

MATHEUS, Renato Fabiano; PARREIRAS, Fernando Silva; PARREIRAS, Tatiane A. Silva. Análise de redes sociais como metodologia de apoio para a discussão da interdisciplinaridade na ciência da informação. Ciência da Informação, v. 35, n. 1, p. 72 93, 2006.

MATTOS, Hebe. Das cores do silêncio: os significados da liberdade no sudeste escravista. Campinas: Editora da Unicamp, 2013.

MBEMBE, Achille. Crítica da razão negra. São Paulo: n-1 edições, 2018.

Necropolítica. São Paulo: n-1 edições, 2019.

MELLO, Ludelina de Campos. Entrevista concedida a Maria Dutra Lima. In: SANTANA, Bianca. Vozes insurgentes de mulheres negras: do século 18 à primeira década do século 21. Belo Horizonte: Mazza Edições, 2019.

MENDES, José Sacchetta Ramos. Desígnios da Lei de Terras: imigração, escravismo e propriedade fundiária no Brasil Império. Cad. CRH, Salvador , v. 22, n. 55, p. 173-184.

Ministério da Saúde. Assistência pré-natal: normas e manuais técnicos / equipe de colaboração: Martha Ligia Fajardo... [et al.]. - $3^{\circ}$ ed. Brasília: Ministério da Saúde, 1998. Disponível em: <http://bvsms.saude.gov.br/bvs/publicacoes/pre_natal.pdf>.

Perspectiva da Eqüidade no Pacto Nacional pela Redução da Mortalidade Materna e Neonatal Atenção à Saúde das Mulheres Negras, 2005.

MONTEIRO, Washington de Barros. Curso de Direito civil. Saraiva, 1990. 
MORENO, Renata Faleiros Camargo. Entre a família, o Estado e o mercado: mudanças e continuidades na dinâmica, distribuição e composição do trabalho doméstico e de cuidado. Tese de Doutorado. Universidade de São Paulo, 2019.

MORIGI, Valdir; JACKS, Nilda e GOLIN, Cida. Epistemologias, comunicação e informação. Porto Alegre: Sulina, 2016.

MORRISON, Toni. A origem dos outros: Seis ensaios sobre racismo e literatura. São Paulo: Companhia das Letras, 2019.

Amada. São Paulo: Companhia das Letras, 2007.

MOSTAFA, Solange Puntel. Interview:(english/portuguese) Michael Buckland. InCID: Revista de Ciência da Informação e Documentação, v. 2, n. 1, p. 230-242, 2011.

MOTT, Maria Lúcia de Barros. Submissão e resistência. São Paulo: Contexto, 1988.

MOTT, Luiz. Rosa Egipcíaca: Uma Santa Africana no Brasil. Artigo sobre o livro do autor, publicado sob o mesmo título, s/d. Disponível em:

$<$ https://luizmottblog.wordpress.com/artigos/rosa-egipciaca-uma-santa-africana-no-brasil>.

MOURA, Maria Aparecida. Cultura informacional, redes sociais e lideranças comunitárias: uma parceria necessária. Cultura informacional e liderança comunitária: concepções e práticas. Belo Horizonte: Proflex/UFMG, 2011.

MOURA, Clóvis; MOURA, Soraya Silva. Dicionário da escravidão negra no Brasil. Edusp, 2013.

MOUTINHO, Laura. Diferenças e desigualdades negociadas: raça, sexualidade e gênero em produções acadêmicas recentes. Cad. Pagu [online]. 2014, n.42 [cited 201608-07], p.201-248. Disponível em: <http://www.scielo.br/scielo.php?pid=S0104$83332014000100201 \&$ script $=$ sci_abstract\&tlng=pt $>$.

MOUTINHO, Laura; ALVES, Valéria; MATEUZI, Milena. "Quanto Mais Você Me Nega, Mais Eu Me Reafirmo": Visibilidade e Afetos na Cena Negra Periférica Paulistana. Revista Tomo, 2016. Disponível em: <http://seer.ufs.br/index.php/tomo/article/view/5428/4451>. Acesso em: julho de 2016.

MUKASONGA, Scholastique. A mulher de pés descalços. Trad. Marília Garcia. São Paulo: Nós, 2017.

Baratas. São Paulo: Nós, 2019.

MÜLLER, Jéssica Paola Macedo et al. Epistemicídio e Ciência da Informação: percurso de ausências. Fórum de Estudos em Informação, Sociedade e Ciência, v. 2, n. 1, p. 14-15, 2019.

MUNANGA, Kabengele. Origens africanas do Brasil contemporâneo: histórias, línguas, culturas e civilizações. São Paulo: Editora Global, 2009. 
NASCIMENTO, Abdias. O genocídio do negro brasileiro: processo de um racismo mascarado. São Paulo: Editora Perspectiva, 2016.

O quilombismo: documentos de uma militância pan-africanista. São Paulo, Perspectiva, 2019.

NASCIMENTO, Beatriz do. O Conceito de Quilombo e a Resistência Cultural AfroBrasileira. Sankofa: resgate da cultura afro-brasileira. Rio de Janeiro: Seafro, 2008.

A mulher negra e o amor. In: SANTANA, Bianca. Vozes insurgentes de

mulheres negras: do século 18 à primeira década do século 21. Belo Horizonte: Mazza Edições, 2019.

NASCIMENTO, Gizêlda Melo do. Grandes mães, reais senhoras. In: NASCIMENTO, Elisa Larkin (Ed.). Guerreiras de Natureza: mulher negra, religiosidade e ambiente. Grupo Editorial Summus, 2008.

Ana Cruz. In: DUARTE, Eduardo de Assis (org.). Literatura e afrodescendência no Brasil: antologia crítica. Volume 4: contemporaneidade. Belo Horizonte: Editora UFMG, 2011.

NASCIMENTO, Maria de Lurdes Valle do. O congresso nacional de mulheres negras e a regulamentação do trabalho doméstico. In: SANTANA, Bianca. Vozes insurgentes de mulheres negras: do século 18 à primeira década do século 21. Belo Horizonte: Mazza Edições, 2019.

NASCIMENTO, Vanessa. Deixa eu lutar, "que é pro mundo ficar Odara". In: SANTANA, Bianca. Inovação ancestral de mulheres negras: táticas e políticas do cotidiano. São Paulo: Oralituras: 2019.

NEPOMUCENO, Bebel. Protagonismo ignorado. In: PINSKY, Carla Bassanezi; PEDRO, Joana Maria. Nova história das mulheres no Brasil. São Paulo: Editora Contexto, 2013.

NOBRE, Miriam. Costuras, comidas e coisas concretas da vida. In: SANTANA, Bianca. Inovação ancestral de mulheres negras: táticas e políticas do cotidiano. São Paulo: Oralituras: 2019.

OLIVEIRA, Eduardo. Cosmovisão africana no Brasil: elementos para uma filosofia afrodescendente. Publicação Ibeca, 2003.

OLIVEIRA, Érika. De mãos dadas com hooks. Revista Estudos Feministas, v. 22, n. 3, p. 1001-1003, 2014.

OLIVEIRA, Klebson. Negros e Escrita do Brasil do século XIX. Tese de doutorado. UFBA, 1198 p. Salvador, 2006.

OLIVEIRA, Klebson; LOBO, Tânia. O nome dela era Rosa: epistolografia de uma exescrava no Brasil do século XVIII. In: LOBO, T.; CARNEIRO, Z.; SOLEDADE, J.; ALMEIDA, A.; and RIBEIRO, S. (orgs.). Rosae: linguística histórica, história das línguas 
e outras histórias [online]. Salvador: EDUFBA, 2012. Disponível em:

<http://books.scielo.org/id/67y3k/pdf/lobo-9788523212308-45.pdf>.

OLIVEIRA, Luiz Henrique Silva de. Jussara Santos. In: DUARTE, Eduardo de Assis (org.). Literatura e afrodescendência no Brasil: antologia crítica. Volume 4: contemporaneidade. Belo Horizonte: Editora UFMG, 2011.

ORTOLAN, Luciana Pereira Vicente et al. As temáticas sobre o negro na Ciência da Informação brasileira: Brapci 2.0. Pesquisa Brasileira em Ciência da Informação e Biblioteconomia; Vol. 13, No 1 (2018), v. 24, n. 2, 2018.

OXOSSI, Mãe Stella. Os brincos de Oba Biyi. In: SANTANA, Bianca. Vozes insurgentes de mulheres negras: do século 18 à primeira década do século 21. Belo Horizonte: Mazza Edições, 2019.

PAIXÃO, Marcelo; GOMES, Flávio. História das diferenças e das desigualdades revisitadas: notas sobre gênero, escravidão, raça e pós-emancipação. In: XAVIER, Giovana; FARIAS, Juliana Barreto; DOS SANTOS GOMES, Flávio (Ed.). Mulheres negras no Brasil escravista e do pós-emancipação. São Paulo: Selo Negro Edições, 2012.

PARRELA, Ivana D. O teatro das desordens: garimpo, contrabando e violência no sertão diamantino, 1768-1800. FAPEMIG, 2009.

PENTEADO, Gilmar. A árvore Carolina Maria de Jesus: uma literatura vista de longe. Estudos de Literatura Brasileira Contemporânea, n. 49, p. 19-32, 2016.

PEREIRA, Edilene Machado; GERALDO Aparecida das Graças. Mulheres negras brasileiras: identidades individuais e coletivas revisitadas. Seminário Internacional Acolhendo as Línguas Africanas. Salvador - BA, setembro de 2014. Disponível em: $<$ http://www.siala.uneb.br/pdfs/VSIALA/edilene_machado_pereira.pdf $>$. Acesso em: julho de 2016.

PEREIRA, Neusa Maria. O afro-latino-américa que vive em mim. Texto para o portal do jornalista Marcos Faerman, 2015. Disponível em:

<http://www.marcosfaerman.jor.br/8_NeusaPereira_TX.pdf>.

Pela mulher negra. Jornal Versus, 1977. In: SANTANA, Bianca. Vozes

insurgentes de mulheres negras: do século 18 à primeira década do século 21 . Belo Horizonte: Mazza Edições, 2019.

PÉROLA NEGRA, Jovelina. Sorriso aberto. In: SANTANA, Bianca. Vozes insurgentes de mulheres negras: do século 18 à primeira década do século 21. Belo Horizonte: Mazza Edições, 2019.

PERPÉTUA, Elzira Divina. Literatura brasileira confessional: uma leitura de memórias marginais. Simpósio nacional de letras e linguística-silel, v. 14, n. 20, p. 1-10, 2011.

PILAR, Tula. Frango verde: alimentando-me do lixão. In: SANTANA, Bianca. Inovação ancestral de mulheres negras: táticas e políticas do cotidiano. São Paulo: Oralituras: 2019. 
PINTO, Maria Dulce Pinheiro. Garra Negra. Jornal Versus, 11 a seção Afro-LatinoAmérica. Junho-julho, 1978.

PISANI, Josefina da Silva. Antonieta de Barros. In: DUARTE, Eduardo de Assis (org.). Literatura e afrodescendência no Brasil: antologia crítica. Volume 1: precursores. Belo Horizonte: Editora UFMG, 2011.

RAGO, Margareth. A aventura de contar-se: feminismos, escrita de si e invenções da subjetividade. Campinas: Editora Unicamp, 2013.

RATTS, Alex; RIOS, Flavia. Lélia Gonzalez: Retratos do Brasil Negro. São Paulo: Selo Negro, 2010.

REIS, João José. Rebelião escrava no Brasil: a história do levante dos malês em 1835. Companhia das Letras, 2003.

REIS, Luciana. Mulheres equilibristas: vivências e resistências. In: SANTANA, Bianca. Inovação ancestral de mulheres negras: táticas e políticas do cotidiano. São Paulo: Oralituras, 2019.

REIS, Maria Firmina dos. Prólogo ao romance Úrsula. In: SANTANA, Bianca. Vozes insurgentes de mulheres negras: do século 18 à primeira década do século 21 . Belo Horizonte: Mazza Edições, 2019.

REVEL, Judith. Michel Foucault: conceitos essenciais. São Carlos: Claraluz, 2005.

RIBEIRO, Alessandra. Alessandra Ribeiro em primeira pessoa. In: SANTANA, Bianca. Inovação ancestral de mulheres negras: táticas e políticas do cotidiano. São Paulo: Oralituras: 2019.

RIBEIRO, Matilde. Mulheres negras brasileiras: de Bertioga a Beijing. Revista Estudos Feministas. Rio de Janeiro, volume 3, no 2, 1995, p. 446 - 463. Disponível em: $<$ https://periodicos.ufsc.br/index.php/ref/article/view/16459>.

Mulheres negras: uma trajetória de criatividade, determinação e organização. In: SANTANA, Bianca. Vozes insurgentes de mulheres negras: do século 18 à primeira década do século 21. Belo Horizonte: Mazza Edições, 2019.

RIOS, Ana Lugão; DE CASTRO, Hebe Maria Mattos. Memórias do cativeiro: família, trabalho e cidadania no pós-abolição. Editora Record, 2005.

RIOS, Flavia Matheus; NOGUEIRA, Fabio. Consciência Negra e Socialismo: mobilização racial e redes socialistas na trajetória de Hamilton Cardoso (1954-1999). Revista Semestral do Departamento e do Programa de Pós-Graduação em Sociologia da UFSCar, v. 4, n. 2, p. 507, 2014.

RODRIGUES, Bruno César; CRIPPA, Giulia. A recuperação da informação e o conceito de informação: o que é relevante em mediação cultural? Perspectivas em Ciência da Informação, v. 16, n. 1, p. 45-64, 2011. 
ROMIO, Jasckeline. Casa dos vultos. In: SANTANA, Bianca. Inovação ancestral de mulheres negras: táticas e políticas do cotidiano. São Paulo: Oralituras, 2019.

ROSA, Allan Santos da et al. Pedagoginga, autonomia e mocambagem. São Paulo: Pólen, 2019.

RUFINO, Alzira. Mulher Negra: uma perspectiva histórica. Coletivo de Mulheres Negras da Baixada Santista, 1987.

SANTANA, Bianca. Inovação ancestral de mulheres negras: táticas e políticas do cotidiano. São Paulo: Oralituras: 2019a.

Vozes insurgentes de mulheres negras: do século 18 à primeira década do século 21. Belo Horizonte: Mazza Edições, 2019 b.

Sueli Carneiro: uma biografia. 2020. No prelo.

SANTANA, Maria de Jesus. Resistência. In: SANTANA, Bianca. Inovação ancestral de mulheres negras: táticas e políticas do cotidiano. São Paulo: Oralituras: 2019.

SANTOS, Dalva Regina. Sol na casa oito. In: SANTANA, Bianca. Inovação ancestral de mulheres negras: táticas e políticas do cotidiano. São Paulo: Oralituras, 2019.

SANTOS, Tiganá Santana Neves. A cosmologia africana dos Bantu-Kongo por Bunseki Fu-Kiau: tradução negra, reflexões e diálogos a partir do Brasil. 2019. Tese de Doutorado. Universidade de São Paulo. Disponível em:

$<$ https://www.teses.usp.br/teses/disponiveis/8/8160/tde-30042019-

193540/publico/2019_TiganaSantanaNevesSantos_VCorr.pdf $>$.

SHARPE, Jenny. Ghosts of Slavery: A Literary Archaeology of Black Women's Lives. U of Minnesota Press, 2003.

SCHMIDT, Simone Pereira. Nos becos da memória, a força da narrativa. In: DUARTE, C. CÔRTES, C. PEREIRA, M (org.). Escrevivências: identidade, gênero e violência na obra de Conceição Evaristo. Belo Horizonte: Idea, 2016.

SCHMIDT, Simone. Alzira Rufino. In: DUARTE, Eduardo de Assis (org.). Literatura e afrodescendência no Brasil: antologia crítica. Volume 2: consolidação. Belo Horizonte: Editora UFMG, 2011.

SCHUMAHER, Schuma; BRAZIL, Érico Vital. Mulheres negras do Brasil. Senac, 2007.

SELIGMANN-SILVA, Márcio. História, memória, literatura: o testemunho na era das catástrofes. Campinas: Editora Unicamp, 2003.

SENADO FEDERAL. Pronunciamento de Benedita da Silva em 21/3/1995. Disponível em: <https://www25.senado.leg.br/web/atividade/pronunciamentos/-/p/texto/165765>. 
SILVA, Ana Santiago da. Memórias e (re) invenções de identidades na literatura afrofeminina. São Paulo, XI Congresso Internacional da ABRALIC: Tessituras, Interações, Convergência, 2008.

SILVA, Benedita. Pronunciamento no Senado Federal em 21/3/1995. In: SANTANA, Bianca. Vozes insurgentes de mulheres negras: do século 18 à primeira década do século 21. Belo Horizonte: Mazza Edições, 2019.

SILVA, Carolina Rocha. Coisa de preto: ancestralidade, criatividade e magia. In: SANTANA, Bianca. Inovação ancestral de mulheres negras: táticas e políticas do cotidiano. São Paulo: Oralituras, 2019.

SILVA, Cidinha. \#Parem de nos matar!. São Paulo: Editora Ijumaa, 2016.

. O Rap das meninas. In: SANTANA, Bianca. Vozes insurgentes de mulheres

negras: do século XVIII à primeira década do século XXI. Belo Horizonte: Mazza Edições, 2019.

SILVA, Josefina da et al. Antonieta de Barros-Maria da Ilha: discurso e catequese. 1991.

SILVA, Leandro Alves da.; MOTA, José Monteiro da.; OLIVEIRA, Maria Daise.; FRANÇA, João Vieira de. Carta de esperança Garcia: uma mensagem de coragem, cidadania e ousadia. Edital Ministério da Cultura/ UFPE. Preservação de acesso aos bens do patrimônio Afro-Brasileiro, 2013. Disponível em:

$<$ http://culturadigital.br/cartaesperancagarcia/>.

SILVA, Lívia Milena da. Travessias entre secas e girassóis. In: SANTANA, Bianca. Inovação ancestral de mulheres negras: táticas e políticas do cotidiano. São Paulo: Oralituras, 2019.

SILVA, Rubens Alves da. A atualização de tradições: performances e narrativas afrobrasileiras. São Paulo: LCTE Editora, 2012.

SILVA, Sandra. Magia negra. In: SANTANA, Bianca. Inovação ancestral de mulheres negras: táticas e políticas do cotidiano. São Paulo: Oralituras, 2019.

SMIT, Johanna W. et al. A determinação do campo científico da Ciência da Informação: uma abordagem terminológica. DataGramaZero-Revista de Ciência da Informação, v. 5, n. 1, 2004. Disponível em: <http://egov.ufsc.br/portal/sites/default/files/anexos/2957429590-1-PB.pdf>.

SOARES, Cecília Moreira. As ganhadeiras: mulher e resistência negra em Salvador no século XIX. Salvador: Ceao-UFBA, 1996. Disponível em:

<https://portalseer.ufba.br/index.php/afroasia/article/download/20856/13456>.

SODRÉ, Muniz. Pensar Nagô. Petrópolis: Vozes, 2017.

SOMÉ, Sobonfu. O espírito da intimidade: ensinamentos ancestrais africanos sobre maneiras de se relacionar. São Paulo: Odysseus, 2003, p. 1. 
SOUZA, Clementino; DEMARTINI, Zeila; GONÇALVES, Marlene (orgs.). Gênero, diversidade e resistência: escritas de si e experiências de empoderamento. 1 ed. Curitiba: Editora CRV, 2016.

SOUZA, Valéria Alves de; MOUTINHO, Laura. Ilú Oba de Min: subvertendo fronteiras: percepções de raça, gênero e sexualidade em um bloco carnavalesco de mulheres. Resumos, 2009.

TÁLAMO, M.F.G.M.; SMIT, J.W. Ciência da Informação: pensamento informacional e integração disciplinar. Brazilian Journal of Information Science, v.1, n.1, p.33-57, jan./jul, 2007.

TAYLOR, Diana. O arquivo e o repertório: performance e memória cultural nas Américas. Editora UFMG, 2013.

TELLES, Lorena Féres da Silva. Libertas entre sobrados: mulheres negras e trabalho doméstico em São Paulo (1880-1920). Alameda, 2013.

THEODORO, Helena. Mito e espiritualidade: mulheres negras. Pallas Editora e Distribuidora, 1996.

TOMAÉL, Maria Inês; MARTELETO, Regina Maria. Redes sociais: posições dos atores no fluxo da informação. Encontros Bibli: revista eletrônica de biblioteconomia e ciência da informação, n. Especial 1, 2006.

TRINDADE, Azoilda Loretto da. Valores civilizatórios e a educação infantil: uma contribuição afro-brasileira. In: BRANDÃO, Ana Paula; TRINDẢDE, Azoilda Loretto da (orgs.). Modos de brincar: caderno de atividades, saberes e fazeres. Rio de Janeiro: Fundação Roberto Marinho, 2010. Disponível em:

$<$ http://www.acordacultura.org.br/sites/default/files/kit/MODOSBRINCAR-WEBCORRIGIDA.pdf $>$.

VIANA, Larissa. O idioma da mestiçagem: as irmandades de pardos na América portuguesa. Campinas: Editora Unicamp, 2007.

VIDIGAL, Pedro Maciel. Os Antepassados. Belo Horizonte: Imprensa Oficial, 1980. Tomo 1. Os Carneiros. Arquivo da Cúria de Mariana e Arquivo da Casa Setecentista de Mariana. Arquivo Público Mineiro.

VIEIRA, Aline Deyques. Memória coletiva e a questão do trauma em Becos da Memória. In: DUARTE, C.; CÔRTES, C.; PEREIRA, M (orgs.). Escrevivências: identidade, gênero e violência na obra de Conceição Evaristo. Belo Horizonte: Idea, 2016.

VIEIRA, Luana. Mulheres negras mantêm a fé, os saberes e os sabores de (re)existir. In: SANTANA, Bianca. Inovação ancestral de mulheres negras: táticas e políticas do cotidiano. São Paulo: Oralituras, 2019.

WAISELFISZ, Julio Jacobo. Mapa da Violência 2015: Homicídio de mulheres no Brasil. Brasília, 2015. Disponível em: <http://www.mapadaviolencia.org.br>. 
WEIL, Simone. A condição operária e outros estudos sobre a opressão. Rio de Janeiro: Paz e Terra, 1979.

WERNECK, Jurema. O Samba Segundo as Ialodês: mulheres negras e a cultura midiática. Rio de Janeiro. Tese (Doutorado)-Programa de Pós-graduação em Comunicação. Universidade Federal do Rio de Janeiro, 2007.

De Ialodês a feministas. Reflexões sobre a ação política das mulheres negras na América Latina e Caribe. In: SANTANA, Bianca. Vozes insurgentes de mulheres negras: do século 18 à primeira década do século 21. Belo Horizonte: Mazza Edições, 2019.

WELLMAN, Barry. Network Analysis: Some Basic Principles. Sociological Theory, vol. 1, p. 155-200, 1983. Disponível em:

<https://courses.cit.cornell.edu/info435_2006sp/w13/wellman.pdf>. Acesso em: mar 2016.

WISSENBACH, Maria Cristina Cortez. Teodora Dias da Cunha: construindo um lugar para si no mundo da escrita da escravidão. In: XAVIER, Giovana; FARIAS, Juliana Barreto; DOS SANTOS GOMES, Flávio (Ed.). Mulheres negras no Brasil escravista e do pósemancipação. São Paulo: Selo Negro Edições, 2012.

XAVIER, Giovana. A hora da estrela: Maria de Lurdes Vale Nascimento e as "amigas leitoras" do Jornal O Quilombo (Rio de Janeiro, 1948-1950). In: CHALHOUB, Sidney; PINTO, Ana Flávia Magalhães. Pensadores negros - pensadoras negras: Brasil séculos XIX e XX. Belo Horizonte: Fino Traço, 2016.

XAVIER, Giovana; FARIAS, Juliana Barreto; DOS SANTOS GOMES, Flávio (org.). Mulheres negras no Brasil escravista e do pós-emancipação. Selo Negro Edições, 2012.

WERSIG, G. Information Science: the study of postmodern knowledge usage. Information Processing \& Management, v.29, n.2, p.229-239, 1993.

ZARIAS, Alexandre. A família do direito e a família no direito: a legitimidade das relações sociais entre a lei e a Justiça. Rev. bras. Ci. Soc. [online]. 2010, vol.25, n.74, pp.61-76. Disponível em: <https://doi.org/10.1590/S0102-69092010000300004>.

Zumthor, Paul. Performance, recepção, leitura. São Paulo: Cosac Naify, 2014. 


\section{ANEXO 1: Levantamento de escritos de mulheres negras, publicados até 2013, acompanhado de dados históricos de contexto}

\begin{tabular}{|c|c|c|c|}
\hline Ano inicial & Ano final & Acontecimento & Detalhes e referências \\
\hline 1607 & 1694 & Quilombo dos Palmares & $\begin{array}{l}\text { No mesmo período, se intensificou } \\
\text { o tráfico africano no Brasil, com a } \\
\text { entrada de aproximadamente } 784 \\
\text { mil pessoas escravizadas (LAGO, } \\
2014, \text { p. } 408 \text { ) }\end{array}$ \\
\hline 1720 & & $\begin{array}{l}\text { Primeiras notícias sobre } \\
\text { experiência de ensino de } \\
\text { pessoas negras no Brasil } \\
\text { colônia }\end{array}$ & $\begin{array}{l}\text { Mulheres escravizadas passam a } \\
\text { ser admitidas em instituições de } \\
\text { ensino onde antes só eram } \\
\text { permitidas as chamadas } \\
\text { sinhazinhas (SCHUMACHER; } \\
\text { VITAL, 2007, p. 211-212) }\end{array}$ \\
\hline 1750 & & $\begin{array}{c}\text { Rosa Egipcíaca escreve, nesta } \\
\text { década, o livro Sagrada } \\
\text { Teologia do Amor de Deus } \\
\text { Luz Brilhante das Almas } \\
\text { Peregrinas }\end{array}$ & $\begin{array}{l}\text { Além das cerca de } 250 \text { páginas da } \\
\text { obra, a africana escravizada, } \\
\text { condenada na década seguinte } \\
\text { pela Inquisição, escreveu } \\
\text { inúmeras cartas (MOTT, L., s/d; } \\
\text { OLIVEIRA, K.; LOBO, 2012) }\end{array}$ \\
\hline 1770 & & $\begin{array}{l}\text { Esperança Garcia, africana } \\
\text { escravizada, escreve uma } \\
\text { carta ao então governador do } \\
\text { Piauí denunciando os maus } \\
\text { tratos a que era submetida }\end{array}$ & (SILVA et al, 2013) \\
\hline 1773 & & $\begin{array}{l}\text { Abolição da escravidão em } \\
\text { Portugal continental }\end{array}$ & (LAGO, 2014, p. 413) \\
\hline 1791 & 1804 & Revolução Haitiana & $\begin{array}{c}\text { A revolta na Colônia de São } \\
\text { Domingos culminou com a } \\
\text { abolição dos escravos e a } \\
\text { independência do Haiti (LAGO, } \\
\text { 2014, p. 413) }\end{array}$ \\
\hline 1831 & & $\begin{array}{c}\text { Promulgada a primeira lei de } \\
\text { proibição do tráfico negreiro } \\
\text { no Brasil, letra morta por } \\
\text { quase vinte anos }\end{array}$ & $\begin{array}{l}\text { Originou a expressão popular } \\
\text { "para inglês ver". França aboliu } \\
\text { definitivamente o tráfico de } \\
\text { africanos. (LAGO, 2014, p. 416) }\end{array}$ \\
\hline 1831 & & $\begin{array}{c}\text { Abolição da escravidão na } \\
\text { Bolívia }\end{array}$ & (LAGO, 2014, p. 419) \\
\hline 1833 & 1838 & $\begin{array}{l}\text { Escravidão declarada ilegal no } \\
\text { Império Britânico }\end{array}$ & $(\mathrm{LAGO}, 2014$, p. 416) \\
\hline 1835 & 1840 & Cabanagem, no Pará & (LAGO, 2014, p. 416) \\
\hline
\end{tabular}




\begin{tabular}{|c|c|c|c|}
\hline Ano inicial & Ano final & Acontecimento & Detalhes e referências \\
\hline 1835 & & Revolta dos Malês, na Bahia & (LAGO, 2014, p. 417) \\
\hline 1838 & 1841 & Balaiada, no Maranhão & (LAGO, 2014, p. 417) \\
\hline 1845 & & $\begin{array}{l}\text { Promulgada a Bill Aberdeen, } \\
\text { lei inglesa que permitia } \\
\text { apreender embarcações de } \\
\text { qualquer nacionalidade } \\
\text { suspeitas de envolvimento } \\
\text { com o tráfico de escravos }\end{array}$ & $\begin{array}{c}\text { Entre } 1808 \text { e } 1860 \text { foram } \\
\text { capturados aproximadamente } \\
1600 \text { navios negreiros, com cerca } \\
\text { de } 150 \text { mil pessoas encontradas a } \\
\text { bordo }\end{array}$ \\
\hline 1845 & & $\begin{array}{l}\text { Colônias alemãs fundadas em } \\
\text { Petrópolis, Rio de Janeiro }\end{array}$ & $(\mathrm{LAGO}, 2014$, p. 417) \\
\hline 1847 & & $\begin{array}{c}\text { Início das colônias de } \\
\text { parceria, normalmente } \\
\text { malsucedidas, envolvendo } \\
\text { colonos europeus e, São Paulo } \\
\text { e Rio de Janeiro }\end{array}$ & $(\mathrm{LAGO}, 2014$, p. 418) \\
\hline 1850 & & $\begin{array}{c}\text { Lei Eusébio de Queirós, com } \\
\text { a extinção efetiva do tráfico } \\
\text { de africanos }\end{array}$ & (LAGO, 2014, p. 418) \\
\hline 1850 & & Lei de Terras & $\begin{array}{l}\text { Proibiu a cessão de terras públicas } \\
\text { e devolutas, dificultando o acesso } \\
\text { de negras e negros libertos à terra }\end{array}$ \\
\hline 1853 & 1854 & $\begin{array}{l}\text { Abolição da escravidão na } \\
\text { Argentina, Peru e Venezuela }\end{array}$ & (LAGO, 2014, p. 419) \\
\hline 1859 & 1859 & $\begin{array}{l}\text { Maria Firmina dos Reis } \\
\text { publica o romance Úrsula }\end{array}$ & $\begin{array}{l}\text { A maranhense também publicou } \\
\text { poesia, ficção e crônicas na } \\
\text { imprensa, além de recolher e } \\
\text { preservar histórias da tradição oral } \\
\text { e compor um hino para a abolição. } \\
\text { Professora, depois de se aposentar } \\
\text { fundou a primeira escola mista e } \\
\text { gratuita do Maranhão (DUARTE, } \\
\text { 2016, p. 55) }\end{array}$ \\
\hline 1865 & & $\begin{array}{l}\text { Abolição da escravidão nos } \\
\text { Estados Unidos }\end{array}$ & $(\mathrm{LAGO}, 2014$, p. 420) \\
\hline 1864 & 1870 & Guerra do Paraguai & $\begin{array}{l}\text { Mais de } 8 \text { mil ex-escravizados } \\
\text { participaram da guerra (LAGO, } \\
2014, \text { p. } 420)\end{array}$ \\
\hline 1868 & & $\begin{array}{l}\text { Publicação de Navio negreiro, } \\
\text { de Castro Alves e do jornal } O \\
\text { Radical Paulistano, com Luiz } \\
\text { Gama no corpo editorial }\end{array}$ & \\
\hline
\end{tabular}




\begin{tabular}{|c|c|c|c|}
\hline Ano inicial & Ano final & Acontecimento & Detalhes e referências \\
\hline 1870 & 1880 & $\begin{array}{l}\text { Luciana Abreu participa da } \\
\text { sociedade Partenon Literário, } \\
\text { em Porto Alegre - RS }\end{array}$ & $\begin{array}{l}\text { A sociedade reunia quem defendia } \\
\text { a abolição e a república, } \\
\text { arrecadava fundos para libertar } \\
\text { pessoas escravizadas e realizava } \\
\text { saraus literários para aprimorar a } \\
\text { educação das mulheres. A } \\
\text { professora primária se tornou um } \\
\text { dos símbolos da emancipação } \\
\text { feminina gaúcha. (SCHUMAHER } \\
\text { e VITAL, 2007, p. 217) Pública } \\
\text { Preleçôes, uma coletânea de } \\
\text { ensaios, além de discursos na } \\
\text { Revista Partenon Literário, em } \\
\text { 1875 (LOPES, 2011, p. 95-96) }\end{array}$ \\
\hline 1871 & & Lei do Ventre Livre & $\begin{array}{c}\text { Declara livres filhos de } \\
\text { escravizadas nascidos a partir } \\
\text { daquela data e determina a } \\
\text { matrícula de escravizados (LAGO, } \\
\text { 2014, p. 421). Pela lei também foi } \\
\text { facultado às pessoas escravizadas } \\
\text { o direito de acumular pecúlio, o } \\
\text { que favoreceu especialmente } \\
\text { escravizadas e escravizados de } \\
\text { ganho (SOARES, 1996, p. 57) }\end{array}$ \\
\hline 1872 & & $\begin{array}{l}\text { Primeiro censo demográfico } \\
\text { nacional }\end{array}$ & $\begin{array}{l}\text { População total de } 10,1 \text { milhões } \\
\text { de habitantes, com cerca de } 15 \% \\
\text { de escravos (pouco mais de } 1,5 \\
\text { milhão) (LAGO, 2014, p. } 421 \text { ) }\end{array}$ \\
\hline 1880 & & $\begin{array}{c}\text { Criação de impostos } \\
\text { proibitivos sobre o tráfico } \\
\text { interprovincial de pessoas } \\
\text { escravizadas }\end{array}$ & $\begin{array}{c}\text { Entre } 1851 \text { e } 1881 \text { o tráfico } \\
\text { interprovincial teria envolvido } 200 \\
\text { mil pessoas escravizadas (LAGO, } \\
2014, \text { p. } 422 \text { ) }\end{array}$ \\
\hline 1880 & & $\begin{array}{c}\text { Intensificação da campanha } \\
\text { abolicionista }\end{array}$ & $\begin{array}{l}\text { Fundada a Sociedade Brasileira } \\
\text { Contra a Escravidão; publicação } \\
\text { de escritos de André Rebouças, } \\
\text { Luís Gama, além da defesa deste } \\
\text { último a africanos mantidos } \\
\text { ilegalmente na escravidão } \\
\text { (LAGO, 2014, p. 422) }\end{array}$ \\
\hline 1884 & & $\begin{array}{c}\text { Aboliçãa no Ceará e } \\
\text { Amazonas }\end{array}$ & $(\mathrm{LAGO}, 2014$, p. 422) \\
\hline
\end{tabular}




\begin{tabular}{|c|c|c|c|}
\hline Ano inicial & Ano final & Acontecimento & Detalhes e referências \\
\hline 1884 & & $\begin{array}{c}\text { Lei em São Paulo autoriza o } \\
\text { governo provincial a pagar } \\
\text { integralmente a passagem } \\
\text { marítima de imigrantes } \\
\text { europeus } \\
\end{array}$ & $\begin{array}{c}\text { Também é expressiva a imigração } \\
\text { alemã e italiana no Sul do país } \\
\text { (LAGO, 2014, p. 422) }\end{array}$ \\
\hline 1885 & & Lei dos Sexagenários & $\begin{array}{c}\text { Determinou a liberdade de pessoas } \\
\text { escravizadas com } 60 \text { anos ou mais } \\
\text { (LAGO, } 2014, \text { p. } 422 \text { ) }\end{array}$ \\
\hline 1886 & & $\begin{array}{c}\text { Abolição da escravidão em } \\
\text { Cuba }\end{array}$ & (LAGO, 2014, p. 422) \\
\hline 1886 & & $\begin{array}{l}\text { A matrícula revela cerca de } \\
723 \text { mil pessoas escravizadas } \\
\text { no Brasil, aproximadamente } \\
5 \% \text { da população total }\end{array}$ & (LAGO, 2014, p. 422) \\
\hline 1887 & & $\begin{array}{l}\text { Abandono de plantações por } \\
\text { escravizados em São Paulo e } \\
\text { outras províncias }\end{array}$ & (LAGO, 2014, p. 422) \\
\hline 1888 & 1937 & $\begin{array}{c}\text { A imprensa negra se } \\
\text { consolidou com uma } \\
\text { multiplicidade de jornais } \\
\text { semanais ou mensais que } \\
\text { publicaram também textos de } \\
\text { mulheres } \\
\end{array}$ & $\begin{array}{l}\text { Exemplos de periódicos: A voz da } \\
\text { raça, da Frente Negra Brasileira; } \\
\text { Kosmos, Clarim da Alvorada, } \\
\text { Menelik etc (ALVES, 2010, p. 34) }\end{array}$ \\
\hline 1888 & & A Lei Áurea & $\begin{array}{c}\text { no papel, e só no papel, foi abolida } \\
\text { a escravidão no Brasil } \\
\end{array}$ \\
\hline 1889 & & Proclamação da República & \\
\hline 1890 & & $\begin{array}{c}\text { Censo demográfico mostra } \\
\text { um total de } 14,3 \text { milhões de } \\
\text { habitantes no Brasil, com } \\
\text { índice geral de analfabetismo } \\
\text { de } 85 \%\end{array}$ & (LAGO, 2014, p. 424) \\
\hline 1890 & 1940 & $\begin{array}{c}\text { Código Penal, cujo capítulo } \\
\text { XIII criminaliza "vadios e } \\
\text { capoeiras" }\end{array}$ & $\begin{array}{c}\text { No artigo 399: "Deixar de } \\
\text { exercitar profissão, officio, ou } \\
\text { qualquer mister em que ganhe a } \\
\text { vida, não possuindo meios de } \\
\text { subsistência e domicílio certo em } \\
\text { que habite; prover a subsistência } \\
\text { por meio de ocupação proibida por } \\
\text { lei, ou manifestamente offensiva } \\
\text { da moral e dos bons costumes: } \\
\text { Pena - de prisão cellular por } \\
\text { quinze a trinta dias."; e artigo 402: } \\
\text { "Fazer nas ruas e praças públicas } \\
\text { exercícios de agilidade e destreza } \\
\text { corporal conhecidos pela } \\
\text { denominação capoeiragem (...)" }\end{array}$ \\
\hline
\end{tabular}




\begin{tabular}{|c|c|c|c|}
\hline Ano inicial & Ano final & Acontecimento & Detalhes e referências \\
\hline 1900 & & $\begin{array}{l}\text { Auta de Souza publica o } \\
\text { romance Horto }\end{array}$ & $\begin{array}{c}\text { A escritora do Rio Grande do } \\
\text { Norte também escrevia poesias e } \\
\text { colaborava com diversos } \\
\text { periódicos no final do século } 19 \\
\text { (SCHUMACHER; VITAL, } 2007 \text {, } \\
\text { p. 216-457) }\end{array}$ \\
\hline 1902 & & $\begin{array}{c}\text { "Decreto Prinetti" do governo } \\
\text { da Itália proíbe a imigração } \\
\text { subsidiada de italianos para o } \\
\text { Brasil }\end{array}$ & $\begin{array}{c}\text { A imigração burta para o Brasil } \\
\text { entre } 1890 \text { e } 1900 \text { totalizou } 1,2 \\
\text { milhão de pessoas (LAGO, 2014, } \\
\text { p. } 425 \text { ) }\end{array}$ \\
\hline 1907 & & $\begin{array}{c}\text { Mulheres negras publicavam } \\
\text { suas demandas por educação e } \\
\text { pela abertura dos meios de } \\
\text { comunicação às suas causas } \\
\text { no jornal Alvorada, em } \\
\text { Pelotas, Rio Grande do Sul }\end{array}$ & $\begin{array}{c}\text { (SCHUMAHER; VITAL, 2007, p. } \\
\text { 218) }\end{array}$ \\
\hline 1916 & & $\begin{array}{l}\text { Maria Dimpina Lobo Duarte } \\
\text { participa da fundação do } \\
\text { Grêmio Literário Júlia Lopes, } \\
\text { responsável pela edição da } \\
\text { revista Violeta, em Cuiabá }\end{array}$ & $\begin{array}{l}\text { Com bacharelado em ciências e } \\
\text { letras, foi professora, fundou } \\
\text { escolas e a Federação Mato- } \\
\text { Grossense pelo Progresso } \\
\text { Feminino (SCHUMAHER; } \\
\text { VITAL, 2007, p. 219) }\end{array}$ \\
\hline 1920 & & $\begin{array}{l}\text { Antonieta de Barros foi } \\
\text { jornalista e deputada em Santa } \\
\text { Catarina }\end{array}$ & $\begin{array}{l}\text { Aprendeu a ler com estudantes } \\
\text { que moravam no pensionato que } \\
\text { sua mãe, lavadeira, abriu depois } \\
\text { da morte do pai. Fundou uma } \\
\text { escola para alfabetizar crianças } \\
\text { (NEPOMUCENO, 2013, p. 390) } \\
\end{array}$ \\
\hline 1933 & & $\begin{array}{c}\text { Adelaide de Castro Alves } \\
\text { Guimarães publica } O \text { Imortal }\end{array}$ & $\begin{array}{l}\text { A escritora baiana que viveu no } \\
\text { Rio de Janeiro era irmã de Castro } \\
\text { Alves (LOPES, 2011, p. 19) }\end{array}$ \\
\hline 1935 & & $\begin{array}{c}\text { Eunice Cunha foi colunista do } \\
\text { jornal negro } O \text { Clarim } \\
\text { d'Alvorada, convocando } \\
\text { mulheres negras à luta política }\end{array}$ & \begin{tabular}{|c|} 
O jornal que circulou em São \\
Paulo entre 1929 e 1940 tinha \\
como um dos objetivos valorizar \\
as mulheres negras. (NEPO- \\
MUCENO, 2013, p. 390-391) \\
\end{tabular} \\
\hline 1937 & & $\begin{array}{l}\text { Antonieta de Barros lança o } \\
\text { livro Farrapo de ideias }\end{array}$ & $\begin{array}{l}\text { A escritora catarinense também } \\
\text { assinava textos como Maria da } \\
\text { Ilha. Professora, era conhecida } \\
\text { como "A Negrinha". Era membro } \\
\text { do Centro Catharinense de Letras, } \\
\text { foi deputada em duas diferentes } \\
\text { ocasiões. Publicou cerca de } 150 \\
\text { textos em jornais que tratavam de } \\
\text { educação, cultura, condição } \\
\text { feminina e preconceito racial. } \\
\text { (PISANI, 2011, p. 377-379) }\end{array}$ \\
\hline
\end{tabular}




\begin{tabular}{|c|c|c|c|}
\hline Ano inicial & Ano final & Acontecimento & Detalhes e referências \\
\hline 1948 & & $\begin{array}{c}\text { Maria de Lurdes Vale } \\
\text { Nascimento funda o jornal } \\
\text { Quilombo: vida, problemas e } \\
\text { aspirações do negro, do } \\
\text { Teatro Experimental do } \\
\text { Negro, com Abdias do } \\
\text { Nascimento } \\
\end{array}$ & $\begin{array}{c}\text { Jornalista, assistente social, } \\
\text { ativista e professora, coordenava } \\
\text { no jornal a coluna "Fala a Mulher" } \\
\text { (XAVIER, 2016, p. 262-263) }\end{array}$ \\
\hline 1940 & 1950 & $\begin{array}{l}\text { Os censos que incluíram o } \\
\text { quesito cor da pele mostrou } \\
\text { como as mulheres negras } \\
\text { eram as mais excluídas do } \\
\text { sistema educacional }\end{array}$ & $\begin{array}{l}\text { Apenas } 15,29 \% \text { das mulheres } \\
\text { negras eram alfabetizadas } \\
\text { (NEPOMUCENO, 2013, p. 392). } \\
\text { No total, } 77,4 \% \text { da população } \\
\text { brasileira com mais de } 10 \text { anos de } \\
\text { idade era alfabetizada } \\
\text { (FERRARO, 2012) }\end{array}$ \\
\hline 1946 & & $\begin{array}{l}\text { Ruth Guimarães publica o } \\
\text { romance Água Funda }\end{array}$ & $\begin{array}{l}\text { Escritora, folclorista e teatróloga } \\
\text { colaborou na imprensa paulista e } \\
\text { carioca (SCHUMACHER; } \\
\text { VITAL, 2007, p. 457) }\end{array}$ \\
\hline 1945 & 1946 & $\begin{array}{c}\text { Convenção Nacional do } \\
\text { Negro }\end{array}$ & $\begin{array}{c}\text { Um dos objetivos do evento } \\
\text { acadêmico era se contrapor aos } \\
\text { congressos que insistiam em } \\
\text { colocar pessoas negras como } \\
\text { objeto de estudo. A primeira } \\
\text { etapa, em São Paulo, gerou um } \\
\text { manifesto que reivindicava que se } \\
\text { tornasse crime de lesa-pátria o } \\
\text { preconceito de cor e de raça. } \\
\text { (SCHUMACHER; VITAL, 2007, } \\
\text { p. 298) }\end{array}$ \\
\hline 1946 & & $\begin{array}{l}\text { Criada a Associação das } \\
\text { Empregadas Domésticas }\end{array}$ & $\begin{array}{c}\text { Com a participação de Arinda } \\
\text { Serafim, Marina Gonçalves e Ruth } \\
\text { Sousa, do Teatro Experimental do } \\
\text { Negro, além de Elza de Souza } \\
\text { (SCHUMACHER; VITAL, 2007, } \\
\text { p. 298) } \\
\end{array}$ \\
\hline 1947 & & $\begin{array}{c}\text { Virgínia Leone Bicudo } \\
\text { publica sua tese sobre } \\
\text { preconceito racial no Brasil e } \\
\text { consciência negra }\end{array}$ & $\begin{array}{c}\text { A socióloga e psicanalista } \\
\text { publicou diversos textos em } \\
\text { jornais de grande circulação e } \\
\text { relevantes publicações acadêmicas } \\
\text { do período (DAMACENO, 2016, } \\
\text { p. } 253 \text { ) } \\
\end{array}$ \\
\hline 1950 & & $\begin{array}{l}\text { Maria de Lurdes Vale do } \\
\text { Nascimento funda o Conselho } \\
\text { Nacional das Mulheres } \\
\text { Negras, outro braço do Teatro } \\
\text { Experimental do Negro }\end{array}$ & $\begin{array}{l}\text { (SCHUMACHER; VITAL, 2007, } \\
\text { p. 297) }\end{array}$ \\
\hline
\end{tabular}




\begin{tabular}{|c|c|c|c|}
\hline Ano inicial & Ano final & Acontecimento & Detalhes e referências \\
\hline 1953 & & $\begin{array}{c}\text { Laura Santos publica três } \\
\text { livros de poemas: Sangue } \\
\text { Tropical, Poemas da noite e } \\
\text { Desejo }\end{array}$ & $\begin{array}{l}\text { Os poemas tinham o erotismo e o } \\
\text { desejo de liberdade como } \\
\text { temáticas principais da escritora } \\
\text { que nasceu em Curitiba, Paraná, e } \\
\text { colaborou assiduamente em } \\
\text { jornais e revistas literárias. Foi } \\
\text { sócia fundadora da Academia de } \\
\text { Letras José de Alencar e integrou } \\
\text { o Centro de Letras do Paraná. } \\
\text { (KAMITA, 2011, p. 484) }\end{array}$ \\
\hline 1956 & & $\begin{array}{l}\text { Anajá Caetano lança Pedras } \\
\text { Altas, romance passado na } \\
\text { época da escravidão }\end{array}$ & $\begin{array}{c}\text { Autora também de Negra } \\
\text { Efigênia, paixão do senhor } \\
\text { branco, No silêncio da casa } \\
\text { grande e Oitavo pecado, os dois } \\
\text { últimos premiados pela Academia } \\
\text { Brasileira de Letras nos anos } 1960 \\
\text { (LOPES, 2011, p. 22) }\end{array}$ \\
\hline 1960 & & $\begin{array}{l}\text { Carolina Maria de Jesus } \\
\text { publica Quarto de despejo }\end{array}$ & $\begin{array}{l}\text { Somente no ano do lançamento, } \\
\text { foi editado oito vezes, com } \\
\text { tiragens de } 10 \text { mil exemplares } \\
\text { cada. Em dez anos havia sido } \\
\text { traduzido para } 14 \text { línguas } \\
\text { (EVARISTO, 2016, p. 302) }\end{array}$ \\
\hline 1960 & 1970 & $\begin{array}{c}\text { Publicação em mimeógrafo de } \\
\text { diversos textos teóricos e } \\
\text { ficcionais que } \\
\text { problematizavam a condição } \\
\text { das mulheres negras dentro e } \\
\text { fora do movimento negro }\end{array}$ & (ALVES, 2010, p. 67) \\
\hline 1965 & & $\begin{array}{l}\text { Vera Teresa de Jesus publica } \\
\text { Ela e a reclusão }\end{array}$ & $\begin{array}{c}\text { A escritora é também ex- } \\
\text { presidiária (LOPES, 2011, p. 157) }\end{array}$ \\
\hline 1972 & & $\begin{array}{c}\text { Magdalena de Souza publica } \\
\text { poemas reunidos na coletânea } \\
\text { O tema que não é esquecido }\end{array}$ & $\begin{array}{c}\text { A escritora paulistana publicou } \\
\text { também em Cadernos Negros } \\
\text { (LOPES, 2011, p. 100) }\end{array}$ \\
\hline 1976 & & $\begin{array}{l}\text { Centro de Estudos Culturais } \\
\text { Afro-Brasileiro Zumbi, de } \\
\text { Santos, São Paulo, publica em } \\
\text { mimeógrafo a Coletânea de } \\
\text { poesia negra }\end{array}$ & (CUTI, 2010, p. 127) \\
\hline 1977 & & $\begin{array}{l}\text { Lançado o jornal Sinba, no } \\
\text { Rio de Janeiro, a coletânea } \\
\text { Negrices, em São Paulo }\end{array}$ & (CUTI, 2010, p. 127) \\
\hline
\end{tabular}




\begin{tabular}{|c|c|c|c|}
\hline Ano inicial & Ano final & Acontecimento & Detalhes e referências \\
\hline 1977 & & $\begin{array}{l}\text { Neusa Maria Pereira publica o } \\
\text { texto "Pela Mulher Negra", no } \\
\text { Jornal Versus }\end{array}$ & $\begin{array}{l}\text { O texto dá origem à seção Afro- } \\
\text { Latino-América do Versus } \\
\text { (PEREIRA, N., 2015) }\end{array}$ \\
\hline 1977 & & $\begin{array}{l}\text { Amélia Maria de Almeida } \\
\text { Alves publica a coletânea de } \\
\text { poemas Vácuo e paisagem }\end{array}$ & $\begin{array}{c}\text { A escritora nasceu em Campos, } \\
\text { Rio de Janeiro (LOPES, 2011, p. } \\
\text { 21) }\end{array}$ \\
\hline 1978 & & $\begin{array}{l}\text { Lançada a coluna Afro- } \\
\text { Latino-América do Versus, a } \\
\text { Revista Tição, de Porto } \\
\text { Alegre, jornais Abertura e } \\
\text { Capoeira, de São Paulo }\end{array}$ & (CUTI, 2010, p. 127) \\
\hline 1978 & & $\begin{array}{c}\text { Fundado o Movimento Negro } \\
\text { Unificado (MNU) }\end{array}$ & (CUTI, 2010, p. 127) \\
\hline 1978 & & $\begin{array}{l}\text { Maria de Lourdes Teodoro } \\
\text { publicou a coletânea de } \\
\text { poemas Água marinha ou } \\
\text { Tempo sem palavras }\end{array}$ & \begin{tabular}{|c|} 
Escritora nascida em Goiás, \\
integra antologia de poemas de \\
mulheres da diáspora publicada \\
nos Estados Unidos. Doutora pela \\
Sorbonne em Literatura \\
Comparada e crítica literária, tem \\
visibilidade no exterior (LOPES, \\
2011, p. 103) \\
\end{tabular} \\
\hline 1978 & & $\begin{array}{c}\text { Lançamento de Cadernos } \\
\text { Negros, com textos de Célia } \\
\text { Aparecida Pereira, Ângela } \\
\text { Lopes Galvão e seis homens } \\
\text { negros }\end{array}$ & $\begin{array}{c}\text { (CUTI, 2010, p. 128; ALVES, } \\
\text { 2010, p. 68) }\end{array}$ \\
\hline 1978 & & $\begin{array}{c}\text { Aline França estreia na cena } \\
\text { literária com seu romance } \\
\text { Negão Dony }\end{array}$ & $\begin{array}{l}\text { A escritora baiana se firma depois } \\
\text { com o romance } A \text { mulher de } \\
\text { Aleduma, celebrado pelo bloco- } \\
\text { afro Ilê Aiyê, e com grande } \\
\text { repercussão do exterior (LOPES, } \\
\text { 2011, p. } 21 \text { ) }\end{array}$ \\
\hline 1979 & & $\begin{array}{c}\text { Criação do grupo de mulheres } \\
\text { negras Aqualtune }\end{array}$ & (GONZALEZ, 2008, p. 39) \\
\hline 1979 & & $\begin{array}{c}\text { Geni Guimarães publica o } \\
\text { livro de poemas Terceiro } \\
\text { Filho }\end{array}$ & $\begin{array}{l}\text { A escritora do interior de São } \\
\text { Paulo tem publicados romances, } \\
\text { relatos autobiográficos e livros } \\
\text { infantis (LOPES, 2011, p. 71) }\end{array}$ \\
\hline 1980 & & $\begin{array}{c}\text { Criado o grupo de escritores } \\
\text { Quilombhoje }\end{array}$ & (CUTI, 2010, p. 129) \\
\hline 1980 & & $\begin{array}{l}\text { Criação do grupo de mulheres } \\
\text { negras Luiza Mahin }\end{array}$ & (GONZALEZ, 2008, p. 39) \\
\hline
\end{tabular}




\begin{tabular}{|c|c|c|c|}
\hline Ano inicial & Ano final & Acontecimento & Detalhes e referências \\
\hline 1981 & & $\begin{array}{c}\text { Maria Mazzarelo cria a Mazza } \\
\text { Ediçães, braço forte do } \\
\text { movimento negro no mercado } \\
\text { editorial }\end{array}$ & $\begin{array}{l}\text { A jornalista nascida em Minas } \\
\text { Gerais tem mestrado na França } \\
\text { (LOPES, 2011, p. 104) }\end{array}$ \\
\hline 1982 & & $\begin{array}{l}\text { Benedita Delazari publica seu } \\
\text { primeiro livro de poemas } \\
\text { Debaixo do pé de sapoti }\end{array}$ & $\begin{array}{c}\text { A atriz e compositora popular } \\
\text { nascida em Sales, interior de São } \\
\text { Paulo, participou também de } \\
\text { edições de Cadernos Negros } \\
\text { (LOPES, 2011, p. 31) }\end{array}$ \\
\hline 1982 & & $\begin{array}{c}\text { Isabel Hirata publica a } \\
\text { coletânea de poemas } \\
\text { Cicatrizes } \\
\end{array}$ & (LOPES, 2011, p. 78) \\
\hline 1982 & & $\begin{array}{c}\text { Lélia Gonzalez publica os } \\
\text { ensaios "A mulher negra na } \\
\text { sociedade brasileira" e "Lugar } \\
\text { de negro" }\end{array}$ & $\begin{array}{l}\text { A antropóloga, professora } \\
\text { universitária e destacada militante } \\
\text { dos movimentos negro e de } \\
\text { mulheres deixou diversos outros } \\
\text { ensaios publicados e foi premiada } \\
\text { na Feira de Frankfurt pelo livro } \\
\text { Festas populares no Brasil em } \\
\text { coautoria com Carlos Hasenbalg }\end{array}$ \\
\hline 1982 & & $\begin{array}{l}\text { Marilene Felinto publica As } \\
\text { mulheres do Tijucopapo }\end{array}$ & $\begin{array}{c}\text { A jornalista e escritora nascida em } \\
\text { Pernambuco vive em São Paulo, } \\
\text { onde foi professora universitária e } \\
\text { escreveu para o jornal Folha de S. } \\
\text { Paulo. Tem outras obras de ficção } \\
\text { publicadas, premiadas e traduzidas } \\
\text { (LOPES, 2011, p. 104) }\end{array}$ \\
\hline 1982 & & $\begin{array}{l}\text { Grupo de Mulheres Negras do } \\
\text { Rio de Janeiro }\end{array}$ & (GONZALEZ, 2008, p. 39) \\
\hline 1983 & & $\begin{array}{l}\text { O grupo Quilombhoje passa a } \\
\text { publicar os Cadernos Negros }\end{array}$ & $\begin{array}{l}\text { A organização geral para a ter a } \\
\text { participção de Esmeralda } \\
\text { Ribeiro, Miriam Alves, Sonia } \\
\text { Fátima Conceição e Vera Lúcia } \\
\text { Alves (CUTI, 2010, p. 129). Até o } \\
\text { número 30, } 22 \text { mulheres diferentes } \\
\text { publicaram nos Cadernos Negros } \\
\text { (ALVES, 2010, p. 72). }\end{array}$ \\
\hline 1983 & & $\begin{array}{c}\text { Leda Maria Martins publica o } \\
\text { livro de poemas Cantiga de } \\
\text { amares }\end{array}$ & $\begin{array}{c}\text { A escritora carioca também têm } \\
\text { livros de ensaio. É pesquisadora } \\
\text { de cultura afro-brasileira, docente } \\
\text { da UFMG. Mestra e doutora na } \\
\text { área de literatura. }\end{array}$ \\
\hline 1983 & & $\begin{array}{l}\text { I Encontro de Mulheres de } \\
\text { Favelas e Periferia }\end{array}$ & (GONZALEZ, 2008, p. 42) \\
\hline
\end{tabular}




\begin{tabular}{|c|c|c|c|}
\hline Ano inicial & Ano final & Acontecimento & Detalhes e referências \\
\hline 1983 & & $\begin{array}{l}\text { Criação do Nzinga- Coletivo } \\
\text { de Mulheres Negras, na sede } \\
\text { da Associação de Moradores } \\
\text { do Morro dos Cabritos }\end{array}$ & (GONZALEZ, 2008, p. 42) \\
\hline 1983 & & $\begin{array}{l}\text { Criação do Coletivo de } \\
\text { Mulheres Negras de São } \\
\text { Paulo }\end{array}$ & (THEODORO, 1996) \\
\hline 1986 & & $\begin{array}{c}\text { Criação do Coletivo de } \\
\text { Mulheres Negras da Baixada } \\
\text { Santista }\end{array}$ & (THEODORO, 1996) \\
\hline 1991 & & $\begin{array}{c}\text { Sônia Fátima da Conceição } \\
\text { publica a novela Marcas, } \\
\text { sonhos e raízes }\end{array}$ & $\begin{array}{l}\text { Militante do movimento negro, a } \\
\text { escrita natural de Araraquara, } \\
\text { interior de São Paulo, publicou } \\
\text { poemas e contos em diversos } \\
\text { volumes de Cadernos Negros e } \\
\text { antologias bilingues. Foi membro } \\
\text { do Quilombhoje Literatura } \\
\text { (GONÇALVES, Ana B., 2011) }\end{array}$ \\
\hline 1985 & & $\begin{array}{l}\text { No } 1 \text { Encontro Nacional de } \\
\text { Poetas e Ficcionistas Negros } \\
\text { Brasileiros, as escritoras } \\
\text { Esmeralda Ribeiro e Roseli } \\
\text { Nascimento apresentaram } \\
\text { textos específicos sobre a } \\
\text { escrita feminina }\end{array}$ & $\begin{array}{l}\text { Elas questionavam a maneira } \\
\text { como autores brancos e negros } \\
\text { representavam as mulheres negras } \\
\text { em suas produções (ALVES, } \\
2010, \text { p. } 69 \text { ) }\end{array}$ \\
\hline 1985 & & $\begin{array}{l}\text { Gilzete Marçal publicou o } \\
\text { livro de poemas Periferia }\end{array}$ & $\begin{array}{l}\text { A escritora baiana também } \\
\text { publicou coletâneas poéticas } \\
\text { (LOPES, 2011, p. 72) }\end{array}$ \\
\hline 1985 & & $\begin{array}{c}\text { Terezinha Malaquias publica } \\
\text { a coletânea de poemas Busca } \\
\text { constante }\end{array}$ & $\begin{array}{c}\text { A escritora mineira têm outros } \\
\text { livros publicados e participou de } \\
\text { coletâneas (LOPES, 2011, p. 150) }\end{array}$ \\
\hline 1986 & & $\begin{array}{c}\text { No } 2^{\circ} \text { Encontro Nacional de } \\
\text { Poetas e Ficcionistas Negros, } \\
\text { as escritoras se empenharam } \\
\text { em pautar questões relativas À } \\
\text { escrita feminina na pauta } \\
\text { oficial }\end{array}$ & $\begin{array}{c}\text { Os homens reagiram propondo } \\
\text { que apenas uma das mulheres } \\
\text { pudesse falar, como representante } \\
\text { o que gerou revolta entre as } \\
\text { mulheres (ALVES, 2010, p. 69) }\end{array}$ \\
\hline 1988 & & $\begin{array}{c}\text { Esmeralda Ribeiro publica o } \\
\text { livro de contos Malungos } e \\
\text { milongas }\end{array}$ & $\begin{array}{l}\text { Desde } 1982 \text { a escritora paulistana } \\
\text { integra o Quilombhoje, que } \\
\text { atualmente coordena. Tem } \\
\text { publicados poemas, contos e } \\
\text { críticas em obras coletivas no } \\
\text { Brasil e no exterior. }\end{array}$ \\
\hline
\end{tabular}




\begin{tabular}{|c|c|c|c|}
\hline Ano inicial & Ano final & Acontecimento & Detalhes e referências \\
\hline 1983 & & $\begin{array}{c}\text { Diário de Bitita, de Carolina } \\
\text { Maria de Jesus, é publicado } \\
\text { no Brasil }\end{array}$ & $\begin{array}{c}\text { Somente nove anos depois da } \\
\text { morte da autora, quatro anos após } \\
\text { a publicação na França, o segundo } \\
\text { livro da autora é publicado no } \\
\text { Brasil. O manuscrito teria sido } \\
\text { entregue por Carolina a um grupo } \\
\text { de jornalistas franceses que veio } \\
\text { entrevistá-la depois do sucesso de } \\
\text { Quarto de despejo (PERPÉTUA, } \\
\text { 2011) }\end{array}$ \\
\hline 1983 & & $\begin{array}{c}\text { Francisca Souza da Silva } \\
\text { publica Ai de vós! Diário de } \\
\text { uma doméstica }\end{array}$ & $\begin{array}{c}\text { A escritora nascida em Palmares, } \\
\text { município de Campos, no Rio de } \\
\text { Janeiro, escreve suas memórias } \\
\text { desde a infância (KAMITA, 2011, } \\
\text { p. 173) }\end{array}$ \\
\hline 1987 & & $\begin{array}{l}\text { Maria Helena Vargas da } \\
\text { Silveira publica o livro } E^{\prime} \\
\text { fogo, com poemas, contos e } \\
\text { ensaios }\end{array}$ & $\begin{array}{c}\text { A escritora Esmeralda Ribeiro } \\
\text { publica o livro de contos } \\
\text { Malungos e milongas nascida em } \\
\text { Pelotas, moradora em Porto } \\
\text { Alegre, ambas no Rio Grande do } \\
\text { Sul, é membro da Academia } \\
\text { Pelotense de Letras. Tem outros } \\
\text { livros publicados (LOPES, 2011, } \\
\text { p. 104) }\end{array}$ \\
\hline 1988 & & $\begin{array}{c}\text { Benedita Damasceno lança } \\
\text { Poesia negra do Modernismo } \\
\text { Brasileiro }\end{array}$ & $\begin{array}{l}\text { A escritora nascida em Paracatu, } \\
\text { Minas Gerais, é diplomata e } \\
\text { professora nas áreas de língua e } \\
\text { literatura brasileira (LOPES, 2011, } \\
\text { p. } 31)\end{array}$ \\
\hline 1988 & & $\begin{array}{c}\text { Stella Azevedo publica } E \text { daí } \\
\text { nasceu o encanto... Axê Opô } \\
\text { Afonjá, em coautoria com } \\
\text { Cleo Martins }\end{array}$ & $\begin{array}{l}\text { A ialorixá responsável pelo } \\
\text { prestigioso Ilê Axê Opó Afonjá, } \\
\text { em Salvador, Bahia, destacou-se } \\
\text { como líder religiosa e política. } \\
\text { Tem outros livros publicados } \\
\text { (LOPES, 2011, p. 147) }\end{array}$ \\
\hline 1988 & & $\begin{array}{c}\text { Alzira Rufino publica o livro } \\
\text { de poesias Eu, mulher negra, } \\
\text { resisto }\end{array}$ & $\begin{array}{l}\text { Nascida em Santos, São Paulo, a } \\
\text { escritora fundou o Coletivo de } \\
\text { Mulheres Negras da Baixada } \\
\text { Santista e coordenou a Casa de } \\
\text { Cultura da Mulher Negra. } \\
\text { Publicou, além de poemas, } \\
\text { crônicas, mini contos e ensaios } \\
\text { (SCHMIDT, Simone, 2011, p. } \\
\text { 366) }\end{array}$ \\
\hline
\end{tabular}




\begin{tabular}{|c|c|c|c|}
\hline Ano inicial & Ano final & Acontecimento & Detalhes e referências \\
\hline 1989 & & $\begin{array}{c}\text { Maria Cristina Campos } \\
\text { publica a coletânea de poemas } \\
\text { Algum lugar }\end{array}$ & $\begin{array}{c}\text { A escritora e líder comunitária } \\
\text { carioca tem outra coletânea de } \\
\text { poemas publicada (LOPES, 2011, } \\
\text { p. 102) }\end{array}$ \\
\hline 1989 & & $\begin{array}{l}\text { Cyana Leahy-Dios publica o } \\
\text { livro de poesia Biombo }\end{array}$ & \\
\hline 1990 & & $\begin{array}{l}\text { Conceição Evaristo publica } \\
\text { um texto pela primeira vez, } \\
\text { em Cadernos Negros }\end{array}$ & (ALVES, 2010, p. 73) \\
\hline 1990 & & $\begin{array}{l}\text { Elisa Lucinda publica Aviso } \\
\text { da lua que menstrua }\end{array}$ & $\begin{array}{l}\text { A escritora e atriz nascida em } \\
\text { Vitória vive no Rio de Janeiro } \\
\text { desde 1986. Tem nove livros } \\
\text { publicados (LOPES, 2011, p. 57) }\end{array}$ \\
\hline 1990 & & $\begin{array}{l}\text { Maria Fenny Batista publica a } \\
\text { coletânea de poemas Estrela } \\
\text { da infância eterna }\end{array}$ & $\begin{array}{l}\text { A escritora nascida em Uberaba, } \\
\text { Minas Gerais, moradora de } \\
\text { Campinas, São Paulo, publicou } \\
\text { poemas em antologias desde } 1971 \\
\text { (LOPES, 2011, p. 104) }\end{array}$ \\
\hline 1992 & & $\begin{array}{l}\text { Carmela Pereira publica } \\
\text { Manual da empregada } \\
\text { doméstica }\end{array}$ & \\
\hline 1995 & & $\begin{array}{c}\text { Lançamento do livro bilíngue } \\
\text { Enfim nós, escritoras negras } \\
\text { brasileiras contemporâneas, } \\
\text { no Brasil e Estados Unidos, } \\
\text { organizado por Miriam Alves }\end{array}$ & $\begin{array}{c}\text { Segundo Miriam Alves, a } \\
\text { publicação é fruto do embate } \\
\text { ocorrido nove anos antes, durante } \\
\text { o } 2^{\circ} \text { Encontro Nacional de Poetas } \\
\text { e Ficcionistas, entre escritoras e } \\
\text { escritores negros (ALVES, 2010, } \\
\text { p. } 70 \text { ) }\end{array}$ \\
\hline 1995 & & $\begin{array}{l}\text { Ana Cruz publica } E . . . \text { feito de } \\
\qquad l u z\end{array}$ & $\begin{array}{c}\text { A escritora mineira já publicou } \\
\text { outros três livros de poemas e } \\
\text { edita o jornal-mural De Mina } \\
\text { (NASCIMENTO, G., 2011, p. } \\
445)\end{array}$ \\
\hline 1996 & & $\begin{array}{c}\text { Lançamento da revista Raça } \\
\text { Brasil }\end{array}$ & $\begin{array}{c}\text { Em poucos dias foram vendidos os } \\
280 \text { mil exemplares da primeira } \\
\text { edição, em seguida outros } 100 \text { mil. } \\
\text { O lançamento editorial trouxe } \\
\text { mudanças também para a } \\
\text { publicidade e o mercado, que } \\
\text { passaram a repensar o consumo de } \\
\text { pessoas negras (NEPOMUCENO, } \\
\text { 2016, p. } 405 \text { ) }\end{array}$ \\
\hline
\end{tabular}




\begin{tabular}{|c|c|c|c|}
\hline Ano inicial & Ano final & Acontecimento & Detalhes e referências \\
\hline 1996 & & $\begin{array}{c}\text { Sandra Almada publica o livro } \\
\text { de entrevistas Damas negras }\end{array}$ & \begin{tabular}{|c|} 
A jornalista entrevistou atrizes \\
negras para o livro (LOPES, 2011, \\
p. 51)
\end{tabular} \\
\hline 1997 & & $\begin{array}{l}\text { Mãe Beata de Yemonjá lança } \\
\text { Caroço de dendê, livro em } \\
\text { que recria relatos da mitologia } \\
\text { dos orixás jeje-nagôs e sua } \\
\text { própria história de vida }\end{array}$ & $\begin{array}{l}\text { A ialorixá nascida em Salvador } \\
\text { passou a maior parte de sua vida } \\
\text { em Nova Iguaçu, Rio de Janeiro } \\
\text { (LOPES, 2011, p. 30) }\end{array}$ \\
\hline 2001 & & $\begin{array}{l}\text { Lia Vieira publica o romance } \\
\text { Chica da Silva: a mulher que } \\
\text { inventou o mar }\end{array}$ & $\begin{array}{l}\text { (SCHUMACHER; VITAL, 2007, } \\
\text { p. 458) }\end{array}$ \\
\hline 2002 & & $\begin{array}{l}\text { Helena do Sul publica As } \\
\text { filhas da lavadeira }\end{array}$ & $\begin{array}{c}\text { (SCHUMACHER; VITAL, 2007, } \\
\text { p. 458) }\end{array}$ \\
\hline 2002 & & $\begin{array}{c}\text { Jussara Freitas publica } D e \\
\text { flores artificiais }\end{array}$ & $\begin{array}{c}\text { Doutora, mestra e bacharel em } \\
\text { letras, a escritora mineira é autora } \\
\text { de diversos artigos sobre literatura } \\
\text { de afrodescendentes, inclusive seu } \\
\text { mestrado e doutorado, além de } \\
\text { poemas premiados e ensaios } \\
\text { (OLIVEIRA, L., 2011, p. 419- } \\
421 \text { ) }\end{array}$ \\
\hline 2003 & & $\begin{array}{c}\text { Conceição Evaristo publica } \\
\text { um livro pela primeira vez: } \\
\text { Ponciá Vicêncio }\end{array}$ & $\begin{array}{l}\text { (SCHUMACHER; VITAL, 2007, } \\
\text { p. } 458)\end{array}$ \\
\hline 2005 & & $\begin{array}{c}\text { Lançada a coletânea de contos } \\
\text { Women righting: Afro- } \\
\text { Brazilian women's short } \\
\text { fiction, organizado por } \\
\text { Miriam Alves, editada na } \\
\text { Inglaterra }\end{array}$ & $\begin{array}{c}\text { Segundo Miriam Alves, a } \\
\text { publicação é fruto do embate } \\
\text { ocorrido nove anos antes, durante } \\
\text { o } 2^{\circ} \text { Encontro Nacional de Poetas } \\
\text { e Ficcionistas, entre escritoras e } \\
\text { escritores negros (ALVES, 2010, } \\
\text { p. 70) }\end{array}$ \\
\hline 2005 & & $\begin{array}{l}\text { Heloísa Pires de Lima lança } \\
\text { Histórias da preta }\end{array}$ & $\begin{array}{c}\text { A escritora paulistana foi editora } \\
\text { responsável por publicações da } \\
\text { Summus Editorial (LOPES, 2011, } \\
\text { p. } 74-76 \text { ) }\end{array}$ \\
\hline
\end{tabular}




\begin{tabular}{|c|c|c|c|}
\hline Ano inicial & Ano final & Acontecimento & Detalhes e referências \\
\hline 2005 & & \begin{tabular}{|} 
Em poucos dias foram \\
vendidos os 280 mil \\
exemplares da primeira \\
edição, em seguida outros 100 \\
mil. O lançamento editorial \\
trouxe mudanças também para \\
a publicidade e o mercado, \\
que passaram a repensar o \\
consumo de pessoas negras \\
(NEPOMUCENO, 2016, p. \\
405)
\end{tabular} & $\begin{array}{c}\text { A escritora carioca criou e } \\
\text { desenvolver nos anos } 1990 \text { o } \\
\text { programa de televisão "Delegacia } \\
\text { de mulheres", que representou o } \\
\text { Brasil na Conferência sobre } \\
\text { violência doméstica promovida } \\
\text { pelo Banco Interamericano de } \\
\text { desenvolvimento em } 1997 . \\
\text { Escreveu peças de teatro e outros } \\
\text { livros. }\end{array}$ \\
\hline 2006 & & $\begin{array}{c}\text { Cidinha da Silva publica Cada } \\
\text { tridente em seu lugar e outras } \\
\text { crônicas }\end{array}$ & $\begin{array}{l}\text { A escritora nascida em Belo } \\
\text { Horizonte, Minas Gerais, tem } \\
\text { intensa militância no Movimento } \\
\text { Negro, coordenou o Programa do } \\
\text { Geledés - Instituto da Mulher } \\
\text { Negra, em São Paulo, e tem } \\
\text { inúmeros livros publicados. } \\
\text { Participou de antologias e produz } \\
\text { ensaios, muitos deles com } \\
\text { reflexões sobre as políticas } \\
\text { públicas de combate às } \\
\text { desigualdades raciais (DUARTE, } \\
\text { 2011, 457-461) }\end{array}$ \\
\hline 2007 & & $\begin{array}{c}\text { Ana Maria Gonçalves lança } \\
\text { Um defeito de cor }\end{array}$ & $\begin{array}{l}\text { O romance de } 952 \text { páginas é uma } \\
\text { narrativa de ficção baseada em } \\
\text { fatos históricos, tendo como fio } \\
\text { condutor a Revolta dos Malês. } \\
\text { (LOPES, 2011) Ganhador do } \\
\text { prêmio Casa de Las Americas. }\end{array}$ \\
\hline 2010 & & $\begin{array}{l}\text { Cristiane Sobral publica Não } \\
\text { vou mais lavar os pratos }\end{array}$ & $\begin{array}{l}\text { A artista fluminense, além de } \\
\text { escritora, é atriz, cantora e } \\
\text { professora de artes cênicas. Além } \\
\text { do livro, tem publicadas peças de } \\
\text { teatro, poemas, contos e críticas } \\
\text { teatrais (FERREIRA, 2011, p. } \\
\text { 505-514) }\end{array}$ \\
\hline 2013 & & $\begin{array}{l}\text { Makota Valdina publica seu } \\
\text { livro de memórias Meu } \\
\text { caminhar, meu viver }\end{array}$ & $\begin{array}{l}\text { A líder religiosa e escritora } \\
\text { nascida em Salvador é autora em } \\
\text { diversas coletâneas de poemas } \\
\text { (LOPES, 2011, p. 157). Recebeu o } \\
\text { título de makota, cargo feminino } \\
\text { de grande valor no candomblé. }\end{array}$ \\
\hline
\end{tabular}


ANEXO 2: Textos aqui considerados clássicos, publicados na coletânea Vozes Insurgentes de Mulheres Negras: do século XVIII à primeira década do século XXI, acompanhados de breve apresentação de cada autora (SANTANA, 2019b)

\begin{tabular}{|c|c|c|c|}
\hline Autora & Breve biografia & Texto publicado & Referência original \\
\hline $\begin{array}{c}\text { Esperança Garcia } \\
\text { (Fazenda } \\
\text { Algodões, PI, } \\
1751-?)\end{array}$ & $\begin{array}{c}\text { Esperança Garcia, mulher } \\
\text { negra africana, escravizada no } \\
\text { século 18. Em 1770, escreveu } \\
\text { esta carta, de próprio punho, } \\
\text { endereçada ao governador do } \\
\text { Piauí. Em } 2017 \text { recebeu o } \\
\text { título de } 1^{\mathrm{a}} \text { advogada do Piauí, } \\
\text { da Ordem dos Advogados do } \\
\text { Brasil (OAB-PI) }\end{array}$ & $\begin{array}{l}\text { Carta de } 1770, \\
\text { endereçada ao então } \\
\text { governador do Piauí }\end{array}$ & (SILVA et al, 2013) \\
\hline $\begin{array}{l}\text { Maria Firmina } \\
\text { dos Reis (São } \\
\text { Luís, MA, 1822 } \\
\text { — Guimarães, } \\
\text { MA, 1917) }\end{array}$ & $\begin{array}{l}\text { Escritora maranhense, } \\
\text { considerada a primeira } \\
\text { romancista brasileira. } \\
\text { Abolicionista, jornalista e } \\
\text { professora. Em } 1859,29 \text { anos } \\
\text { antes da abolição, publica o } \\
\text { romance Úrsula, celebrado } \\
\text { pela imprensa local. }\end{array}$ & $\begin{array}{c}\text { Prólogo ao romance } \\
\text { Ursula }\end{array}$ & (REIS, M., 2018) \\
\hline $\begin{array}{l}\text { Antonieta de } \\
\text { Barros } \\
\text { (Florianópolis, } \\
\text { SC, 1901 - } \\
\text { Florianópolis, SC } \\
\text { - 1952) }\end{array}$ & $\begin{array}{l}\text { Primeira mulher negra } \\
\text { parlamentar, eleita deputada } \\
\text { estadual em Santa Catarina, } \\
\text { em 1934. Professora e } \\
\text { jornalista. Diretora do jornal A } \\
\text { Semana, entre } 1922 \text { e } 1927 .\end{array}$ & $\begin{array}{l}\text { Crônica publicada } \\
\text { em } 12 \text { de abril de } \\
\text { 1934, no jornal } \\
\text { catarinense } \\
\text { República, dedicada } \\
\text { a D. Leopoldina } \\
\text { d'Ávila }\end{array}$ & (SILVA, J., 1991) \\
\hline $\begin{array}{c}\text { Eunice Cunha } \\
\text { (Cajuru, SP, } 1915 \\
\text { - São Paulo, SP, } \\
\text { 2014) }\end{array}$ & $\begin{array}{c}\text { Professora e militante da } \\
\text { Frente Negra Brasileira. } \\
\text { Redatora do jornal Clarim da } \\
\text { Alvorada, possivelmente, entre } \\
1924 \text { e } 1932 .\end{array}$ & $\begin{array}{c}\text { Apelo às mulheres } \\
\text { negras, publicado em } \\
\text { 1935, em O Clarim } \\
\text { C'Alvorada }\end{array}$ & $\begin{array}{l}\text { O professor Amauri } \\
\text { Mendes Pereira, da } \\
\text { UFRJ, fotografou } \\
\text { exemplares do jornal } \\
\text { a meu pedido. Em } \\
\text { bibliotecas e } \\
\text { repositórios digitais, } \\
\text { não foram } \\
\text { encontrados } \\
\text { exemplares do } \\
\text { Clarim com textos } \\
\text { de Eunice Cunha } \\
\text { publicados. }\end{array}$ \\
\hline
\end{tabular}




\begin{tabular}{|c|c|c|c|}
\hline Autora & Breve biografia & Texto publicado & Referência original \\
\hline $\begin{array}{c}\text { Maria de Lurdes } \\
\text { Vale Nascimento } \\
\text { (Franca, SP, } 1924 \\
\text { - Rio de Janeiro, } \\
\text { 1995) }\end{array}$ & $\begin{array}{l}\text { Diretora e gerente do jornal } \\
\text { Quilombo, entre } 1948 \text { e } 1950, \\
\text { quando também publicava a } \\
\text { coluna Fala mulher. Assistente } \\
\text { social e criadora do Conselho } \\
\text { Nacional de Mulheres Negras. }\end{array}$ & $\begin{array}{c}\text { O Congresso } \\
\text { Nacional de } \\
\text { Mulheres e a } \\
\text { Regulamentação do } \\
\text { Trabalho Doméstico, } \\
\text { publicado na edição } \\
\text { no }^{\circ} 04 \text { do Jornal } \\
\text { Quilombo: vida, } \\
\text { problemas e } \\
\text { aspirações do negro, } \\
\text { no Rio de Janeiro, em } \\
1949\end{array}$ & $\begin{array}{c}\text { Exemplares do jornal } \\
\text { Quilombo estão } \\
\text { digitalizados pelo } \\
\text { IPEAFRO: } \\
\text { https://ipeafro.org.br/ } \\
\text { acervo- } \\
\text { digital/leituras/ten- } \\
\text { publicacoes/jornal- } \\
\text { quilombo-no-04/ }\end{array}$ \\
\hline $\begin{array}{c}\text { Laudelina de } \\
\text { Campos Mello } \\
\text { (Poços de Caldas, } \\
\text { MG, } 1904 \text { - } \\
\text { Campinas, SP, } \\
\text { 1991) }\end{array}$ & $\begin{array}{c}\text { Empregada doméstica. Em } \\
\text { 1936, criou a primeira } \\
\text { associação de empregadas } \\
\text { domésticas do país, fechada } \\
\text { pelo Estado Novo, reaberta } \\
\text { por ela em 1946. Durante a } \\
\text { segunda guerra mundial, se } \\
\text { alistou no exército brasileiro. } \\
\text { Foi militante da Frente Negra } \\
\text { Brasileira e depois nas } \\
\text { Comunidades Eclesiais de } \\
\text { Base. }\end{array}$ & $\begin{array}{c}\text { Entrevista concedida } \\
\text { a Maria Dutra de } \\
\text { Lima, na cidade de } \\
\text { Campinas, em } 1990 . \\
\text { Publicada } \\
\text { originalmente na } \\
\text { edição de número } 6 \\
\text { da Revista } \\
\text { Trabalhadores: } \\
\text { classes perigosas, da } \\
\text { Secretaria Municipal } \\
\text { de Cultura, Esporte e } \\
\text { Turismo de } \\
\text { Campinas }\end{array}$ & (MELLO, 1990) \\
\hline $\begin{array}{l}\text { Carolina Maria de } \\
\text { Jesus } \\
\text { (Sacramento, MG, } \\
\text { 1914 - São Paulo, } \\
\text { SP, 1977) }\end{array}$ & $\begin{array}{l}\text { Escritora traduzida para treze } \\
\text { idiomas e publicada em mais } \\
\text { de quarenta países. Até o } \\
\text { lançamento de Quarto de } \\
\text { despejo, em 1960, era catadora } \\
\text { de papel. Seu primeiro livro } \\
\text { vendeu trinta mil exemplares, } \\
\text { na primeira edição, chegando } \\
\text { a cem mil exemplares } \\
\text { vendidos, nas duas edições } \\
\text { seguintes. Publicou mais três } \\
\text { livros em vida: Casa de } \\
\text { Alvenaria (1961), Pedaços de } \\
\text { Fome (1963), Provérbios } \\
\text { (1963). Postumamente, teve } \\
\text { escritos reunidos em Diário de } \\
\text { Bitita (1982), lançado na } \\
\text { França antes de vir para o } \\
\text { Brasil. }\end{array}$ & $\begin{array}{l}\text { Trechos do livro } \\
\text { Quarto de despejo: } \\
\text { diário de uma } \\
\text { favelada, publicado } \\
\text { em São Paulo, em } \\
1960\end{array}$ & (JESUS, 1960) \\
\hline
\end{tabular}




\begin{tabular}{|c|c|c|c|}
\hline Autora & Breve biografia & Texto publicado & Referência original \\
\hline $\begin{array}{c}\text { Neusa Maria } \\
\text { Pereira (São } \\
\text { Paulo, SP, 1955) }\end{array}$ & $\begin{array}{l}\text { Jornalista formada pela } \\
\text { Faculdade Cásper Líbero, foi } \\
\text { repórter e revisora em jornais } \\
\text { da grande imprensa. Criadora } \\
\text { da seção Afro Latino América } \\
\text { do jornal Versus, importante } \\
\text { periódico da imprensa } \\
\text { alternativa, entre } 1975 \text { a } 1979 . \\
\text { Uma das fundadoras do } \\
\text { Movimento Negro Unificado. }\end{array}$ & $\begin{array}{c}\text { Pela mulher negra, } \\
\text { publicado no jornal } \\
\text { Versus, em } 1977 .\end{array}$ & $\begin{array}{l}\text { Todas as edições do } \\
\text { jornal Versus estão } \\
\text { disponíveis em: } \\
\text { <http://www.marcosf } \\
\text { aerman.jor.br/> }\end{array}$ \\
\hline $\begin{array}{l}\text { Leci Brandão } \\
\text { (Rio de Janeiro, } \\
\text { RJ, 1944) }\end{array}$ & $\begin{array}{l}\text { Compositora, cantora, atriz e } \\
\text { política. Primeira mulher a } \\
\text { participar da ala de } \\
\text { compositores da Mangueira. } \\
\text { Formada em Direito. Integrou } \\
\text { o Conselho Nacional de } \\
\text { Promoção da Igualdade Racial } \\
\text { e o Conselho Nacional dos } \\
\text { Direitos da Mulher entre } 2004 \\
\text { e } 2008 \text {. É deputada estadual } \\
\text { em São Paulo, pelo PCdoB, } \\
\text { desde } 2011 .\end{array}$ & $\begin{array}{l}\text { Marias, samba do } \\
\text { álbum Coisas do meu } \\
\text { pessoal, de } 1977\end{array}$ & \\
\hline $\begin{array}{l}\text { Dona Ivone Lara } \\
\text { (Rio de Janeiro, } \\
\text { RJ, } 1922 \text { - Rio de } \\
\text { Janeiro, RJ, 2018) }\end{array}$ & $\begin{array}{c}\text { Compositora e cantora, } \\
\text { conhecida como a Grande } \\
\text { Dama do Samba. Formada em } \\
\text { enfermagem e serviço social, } \\
\text { atuou profissionalmente como } \\
\text { terapeuta ocupacional até se } \\
\text { aposentar, em 1977, quando } \\
\text { passou a se dedicar } \\
\text { integralmente à carreira } \\
\text { artística. }\end{array}$ & $\begin{array}{l}\text { Alguém me avisou } \\
\text { (1981) - do álbum } \\
\text { Sorriso Negro }\end{array}$ & \\
\hline
\end{tabular}




\begin{tabular}{|c|c|c|c|}
\hline Autora & Breve biografia & Texto publicado & Referência original \\
\hline $\begin{array}{c}\text { Lélia Gonzalez } \\
\text { (Belo Horizonte, } \\
\text { MG } 1935 \text { - Rio de } \\
\text { Janeiro, RJ, 1994) }\end{array}$ & $\begin{array}{c}\text { Intelectual que dedicou parte } \\
\text { importante de sua trajetória a } \\
\text { explicar a perversa } \\
\text { combinação de racismo e } \\
\text { sexismo na situação das } \\
\text { mulheres negras. Discutia } \\
\text { linguagem e criou as noções } \\
\text { de amefricanidade e pretuguês. } \\
\text { Historiadora, antropóloga e } \\
\text { professora. Uma das } \\
\text { fundadoras do Movimento } \\
\text { Negro Unificado e do Coletivo } \\
\text { de Mulheres Negras N'Zinga. }\end{array}$ & $\begin{array}{c}\text { Racismo e sexismo } \\
\text { na cultura brasileira, } \\
\text { artigo apresentado na } \\
\text { Reunião do Grupo de } \\
\text { Trabalho "Temas e } \\
\text { Problemas da } \\
\text { População Negra no } \\
\text { Brasil", no IV } \\
\text { Encontro Anual da } \\
\text { Associação Brasileira } \\
\text { de Pós-graduação e } \\
\text { Pesquisa nas } \\
\text { Ciências Sociais, no } \\
\text { Rio de Janeiro, em } 31 \\
\text { de outubro de } 1980 .\end{array}$ & GONZALEZ, 1983 \\
\hline $\begin{array}{l}\text { Mãe Stella de } \\
\text { Oxóssi }\end{array}$ & $\begin{array}{l}\text { Quinta iyalorixá do Ilê Axé } \\
\text { Opó Afonjá, de Salvador, } \\
\text { tombado pelo Instituto do } \\
\text { Patrimônio Histórico e } \\
\text { Artístico Nacional (IPHAN). } \\
\text { Membro da Academia de } \\
\text { Letras da Bahia e doutora } \\
\text { honoris causa pela } \\
\text { Universidade Federal da } \\
\text { Bahia. Reconhecida } \\
\text { mundialmente como } \\
\text { conhecedora da cultura iorubá. } \\
\text { Publicou sete livros. }\end{array}$ & $\begin{array}{l}\text { Os brincos de Oba } \\
\text { Biy, publicado } \\
\text { originalmente no } \\
\text { livro E daí aconteceu } \\
\text { o encanto, de } 1988\end{array}$ & $\begin{array}{l}\text { AZEVEDO, Stella; } \\
\text { MARTINS, Cléo. E } \\
\text { daí aconteceu o } \\
\text { encanto. Axé Opô } \\
\text { Afonjá, 1988. }\end{array}$ \\
\hline $\begin{array}{c}\text { Jovelina Pérola } \\
\text { Negra (Rio de } \\
\text { Janeiro, RJ, } 1944 \\
\text { - Rio de Janeiro, } \\
\text { RJ, 1998) }\end{array}$ & $\begin{array}{l}\text { Compositora e cantora. Foi } \\
\text { empregada doméstica até fazer } \\
\text { sucesso como sambista. } \\
\text { Gravou cinco discos } \\
\text { individuais e conquistou um } \\
\text { Disco de Platina por ter } \\
\text { vendido mais de } 80 \text { mil cópias } \\
\text { do álbum Vou da Fé, de } 1993 .\end{array}$ & $\begin{array}{c}\text { Sorriso aberto, samba } \\
\text { de } 1988\end{array}$ & \\
\hline
\end{tabular}




\begin{tabular}{|c|c|c|c|}
\hline Autora & Breve biografia & Texto publicado & Referência original \\
\hline $\begin{array}{c}\text { Beatriz } \\
\text { Nascimento } \\
\text { (Aracaju, SE, } \\
\text { 1942 - Rio de } \\
\text { Janeiro, RJ, 1995) }\end{array}$ & $\begin{array}{l}\text { Intelectual, historiadora, } \\
\text { roteirista e militante. Foi uma } \\
\text { das principais estudiosas dos } \\
\text { quilombos. Escreveu inúmeros } \\
\text { artigos e o roteiro do } \\
\text { documentário Ôrí, de 1989, } \\
\text { narrado por ela. Uma das } \\
\text { criadoras do Instituto de } \\
\text { Pesquisa das Culturas Negras } \\
\text { (IPCN), em 1975. Foi } \\
\text { assassinada por defender uma } \\
\text { amiga da violência de seu } \\
\text { companheiro, em } 1995 .\end{array}$ & $\begin{array}{l}\text { A Mulher negra e o } \\
\text { amor, artigo } \\
\text { publicado no Jornal } \\
\text { Maioria Falante, em } \\
\text { fevereiro-março de } \\
1990\end{array}$ & $\begin{array}{l}\text { NASCIMENTO, } \\
\text { Beatriz. A mulher } \\
\text { negra e o amor. } \\
\text { Jornal Maioria } \\
\text { Falante, n. } 17, \text { p. } 3 \text {, } \\
\text { 1990. }\end{array}$ \\
\hline $\begin{array}{l}\text { Benedita da Silva } \\
\text { (Rio de Janeiro, } \\
\text { RJ, 1942) }\end{array}$ & $\begin{array}{l}\text { Deputada federal, já foi } \\
\text { vereadora, senadora e } \\
\text { governadora do Rio de } \\
\text { Janeiro. Sua atuação, } \\
\text { primordialmente nos } \\
\text { movimentos de favela, mas } \\
\text { também no movimento negro } \\
\text { e de mulheres foi o início de } \\
\text { sua trajetória política. } \\
\text { Relatora da proposta que deu } \\
\text { origem à chamada PEC das } \\
\text { Domésticas, que estende } \\
\text { direitos trabalhistas à } \\
\text { categoria. É de sua autoria o } \\
\text { projeto de lei que inscreveu } \\
\text { Zumbi dos Palmares no } \\
\text { panteão dos heróis nacionais e } \\
\text { instituiu o dia } 20 \text { de novembro } \\
\text { como o Dia Nacional da } \\
\text { Consciência Negra. Criou } \\
\text { delegacias especiais de } \\
\text { combate a para crimes raciais } \\
\text { e outros projetos populares } \\
\text { importantes. }\end{array}$ & $\begin{array}{c}\text { Pronunciamento no } \\
\text { Senado Federal, em } \\
\text { 21/03/1995 }\end{array}$ & (SENADO, 1995) \\
\hline
\end{tabular}




\begin{tabular}{|c|c|c|c|}
\hline Autora & Breve biografia & Texto publicado & Referência original \\
\hline $\begin{array}{c}\text { Luiza Bairros } \\
\text { (Porto Alegre, } \\
\text { RS, 1953 - Porto } \\
\text { Alegre, RS, 2016) }\end{array}$ & $\begin{array}{c}\text { Administradora, com mestrado } \\
\text { em ciências sociais e doutorado } \\
\text { em sociologia, foi Secretária de } \\
\text { Promoção da Igualdade Racial } \\
\text { da Bahia entre } 2007 \text { e } 2011 \text { e } \\
\text { ministra-chefe da Secretaria de } \\
\text { Políticas de Promoção da } \\
\text { Igualdade Racial do Brasil, } \\
\text { entre } 2011 \text { e } 2014 .\end{array}$ & $\begin{array}{l}\text { Nossos feminismos } \\
\text { revisitados, artigo } \\
\text { publicado na revista } \\
\text { estudos Feministas, } \\
\text { em janeiro de } 1995\end{array}$ & (BAIRROS, 1995) \\
\hline $\begin{array}{c}\text { Elisa Lucinda } \\
\text { (Cariacica, ES, } \\
\text { 1958) }\end{array}$ & $\begin{array}{l}\text { Atriz, poeta, jornalista e } \\
\text { cantora. Publicou seu primeiro } \\
\text { livro de poesias } O \text { Semelhante, } \\
\text { em } 1994, \text { que originou a peça } \\
\text { de mesmo nome, sucesso no } \\
\text { Brasil e no exterior, em cartaz } \\
\text { por mais de seis anos. Tem } \\
\text { catorze livros publicados. }\end{array}$ & $\begin{array}{l}\text { Mulata exportação, } \\
\text { poema publicado } \\
\text { em 1995, no livro o } \\
\text { Semelhante }\end{array}$ & $\begin{array}{c}\text { LUCINDA, Elisa } \\
\text { Lucinda Campos. O } \\
\text { semelhante. Massao } \\
\text { Ohno Ed., } 1994 .\end{array}$ \\
\hline $\begin{array}{l}\text { Nilma Bentes } \\
\text { (Belém, PA, } \\
\text { 1948) }\end{array}$ & $\begin{array}{c}\text { Militante paraense. Graduada } \\
\text { em engenharia agronômica. } \\
\text { Uma das fundadoras do Centro } \\
\text { de Estudos e Defesa do Negro } \\
\text { do Pará (Cedenpa), em Belém. } \\
\text { Idealizadora da Marcha das } \\
\text { Mulheres Negras e a principal } \\
\text { responsável pela incorporação } \\
\text { do bem-viver como bandeira do } \\
\text { movimento. }\end{array}$ & $\begin{array}{l}\text { Brasil - Duban - } \\
\text { Brasil: um marco na } \\
\text { luta contra o } \\
\text { racismo, publicado, } \\
\text { em 2002, na revista } \\
\text { Estudos Feministas }\end{array}$ & $\begin{array}{l}\text { BENTES, Nilma. } \\
\text { Brasil - Durban - } \\
\text { Brasil: um marco da } \\
\text { luta contra o } \\
\text { racismo. Revista } \\
\text { Estudos Feministas, } \\
\text { v. } 10, \text { n. } 1, \text { p. } 229- \\
\text { 236, 2002. }\end{array}$ \\
\hline $\begin{array}{c}\text { Sueli Carneiro } \\
\text { (São Paulo, SP, } \\
\text { 1950) }\end{array}$ & $\begin{array}{l}\text { Umas das mais importantes } \\
\text { intelectuais do Brasil. Feminista } \\
\text { antirracista, militante do } \\
\text { movimento negro e fundadora } \\
\text { do Geledés Instituto da Mulher } \\
\text { Negra. Filósofa, escritora e } \\
\text { doutora em educação. Foi } \\
\text { colunista do Correio } \\
\text { Braziliense. Tem três livros } \\
\text { publicados. Mulher negra: } \\
\text { Política governamental e a } \\
\text { mulher (1985), com Thereza } \\
\text { Santos e Albertina de Oliveira } \\
\text { Costa; Racismo, Sexismo e } \\
\text { Desigualdade no Brasil (2011); } \\
\text { e Sueli Carneiro: escritos de } \\
\text { uma vida (2018). }\end{array}$ & $\begin{array}{c}\text { Mulheres em } \\
\text { movimento, artigo } \\
\text { de } 2003, \text { publicado } \\
\text { na revista estudos } \\
\text { avançados, em São } \\
\text { Paulo }\end{array}$ & $\begin{array}{l}\text { CARNEIRO, S., } \\
2003\end{array}$ \\
\hline
\end{tabular}




\begin{tabular}{|c|c|c|c|}
\hline Autora & Breve biografia & Texto publicado & Referência original \\
\hline $\begin{array}{c}\text { Cida Bento (São } \\
\text { Paulo) }\end{array}$ & $\begin{array}{c}\text { Coordenadora executiva do } \\
\text { Ceert - Centro de Estudos das } \\
\text { Relações de Trabalho e } \\
\text { Desigualdades. Doutora em } \\
\text { psicologia pela Universidade de } \\
\text { São Paulo. }\end{array}$ & $\begin{array}{c}\text { Branquitude e poder } \\
\text { - as questões das } \\
\text { cotas para negros., } \\
\text { texto apresentado } \\
\text { no Simpósio } \\
\text { Internacional do } \\
\text { Adolescente, em } \\
2005\end{array}$ & (BENTO, C., 2005) \\
\hline $\begin{array}{l}\text { Jurema Werneck } \\
\text { (Rio de Janeiro, } \\
\text { RJ, 1961) }\end{array}$ & $\begin{array}{c}\text { Atual diretora da Anistia } \\
\text { Internacional no Brasil. Médica } \\
\text { sanitarista, uma das fundadoras } \\
\text { da ong carioca Criola. Nome } \\
\text { importante no movimento de } \\
\text { mulheres negras. }\end{array}$ & $\begin{array}{l}\text { De ialodês a } \\
\text { feministas: a ação } \\
\text { política das } \\
\text { mulheres negras na } \\
\text { América Latina e } \\
\text { Caribe, artigo } \\
\text { publicado na } \\
\text { Nouvelles } \\
\text { Questions } \\
\text { Féministes }\end{array}$ & (WERNECK, 2005) \\
\hline $\begin{array}{c}\text { Matilde Ribeiro } \\
\text { (Belo Horizonte, } \\
\text { MG, 1967) }\end{array}$ & $\begin{array}{l}\text { Assistente social e ativista } \\
\text { brasileira. Foi ministra-chefe da } \\
\text { Secretaria Especial de Políticas } \\
\text { de Promoção da Igualdade } \\
\text { Racial no Governo Lula. } \\
\text { Professora da Universidade da } \\
\text { Integração Internacional da } \\
\text { Lusofonia Afro-Brasileira, no } \\
\text { campus dos Malês em São } \\
\text { Francisco do Conde, na Bahia. }\end{array}$ & $\begin{array}{l}\text { Mulheres negras: } \\
\text { uma trajetória de } \\
\text { criatividade, } \\
\text { determinação e } \\
\text { organização, artigo } \\
\text { publicado na } \\
\text { Revista Estudos } \\
\text { Feministas }\end{array}$ & (RIBEIRO, 2008) \\
\hline $\begin{array}{c}\text { Cidinha da Silva } \\
\text { (Belo Horizonte, } \\
\text { MG, 1967) }\end{array}$ & $\begin{array}{c}\text { Escritora, com catorze livros } \\
\text { publicados. Historiadora. Foi } \\
\text { presidente do Geledés - } \\
\text { Instituto da Mulher Negra e } \\
\text { gestora de cultura na Fundação } \\
\text { Cultural Palmares. Fundadora } \\
\text { do Instituto Kuanza, que } \\
\text { publica livros e promove ações } \\
\text { de educação e articulação } \\
\text { comunitária sobre a população } \\
\text { negra. }\end{array}$ & $\begin{array}{l}\text { O Rap das meninas, } \\
\text { artigo publicado na } \\
\text { revista Estudos } \\
\text { Feministas }\end{array}$ & (SILVA, 1995) \\
\hline
\end{tabular}




\begin{tabular}{|c|c|c|c|}
\hline Autora & Breve biografia & Texto publicado & Referência original \\
\hline $\begin{array}{c}\text { Conceição } \\
\text { Evaristo (Belo } \\
\text { Horizonte, MG, } \\
\text { 1946) }\end{array}$ & $\begin{array}{c}\text { Escritora. Doutora em } \\
\text { Literatura Comparada, foi } \\
\text { professora na rede pública do } \\
\text { Rio de Janeiro. Militante do } \\
\text { movimento negro, estreou na } \\
\text { literatura em 1990, quando } \\
\text { começou a publicar contos e } \\
\text { poemas na série Cadernos } \\
\text { Negros. }\end{array}$ & $\begin{array}{l}\text { Vozes mulheres, } \\
\text { poema publicado no } \\
\text { livro Poemas de } \\
\text { recordação e outros } \\
\text { movimentos }\end{array}$ & (EVARISTO, 2008) \\
\hline
\end{tabular}




\section{ANEXO 3: Relato da primeira oficina de escrita para mulheres negras, realizada em julho de 2017, em São Paulo}

Esta primeira oficina integrou a programação do \#JulhosDasPretas, organizado pela Marcha das Mulheres Negras de São Paulo. Ao longo do mês de julho de 2017, foram realizadas diversas atividades preparatórias para a Marcha das Mulheres Negras, que aconteceu no 25 de julho: Dia da Mulher Negra Latinoamericana e Caribenha.

Fui convidada a propor alguma atividade para a programação pela jornalista Juliana Gonçalves, uma das organizadoras do Núcleo Impulsor da Marcha. A proposta de oficina já estava em discussão com o orientador e esta pareceu uma oportunidade ímpar para experimentá-la como técnica de pesquisa.

Era importante realizar a atividade em um lugar acessível para mulheres de diversas regiões da cidade, próximo de alguma estação do metrô. Mapeamos possibilidades como o Aparelha Luzia, quilombo urbano, restaurante e centro cultural na região dos Campos Elísios, mas a agenda de julho já estava tomada; e o CIM (Centro de Informação Mulher), organização do movimento de mulheres, cuja sede fica em um prédio comercial no centro da cidade, o que significava a oficina ser realizada, necessariamente, em horário comercial, um fator limitante à participação de mulheres negras trabalhadoras. O Espaço Cult, na Vila Madalena, é uma escola livre que oferece cursos pagos nas áreas de comunicação, editoração e altos estudos. A gestora do espaço, Fernanda Paola, abriu, generosamente, e sem nenhum custo, o espaço para a realização da oficina.

Definimos também a data: quarta-feira, 19 de julho, entre $19 \mathrm{~h}$ e $22 \mathrm{~h} 30$. Vinte vagas. Pela procura que costuma ter as atividades da Marcha e oficinas de escrita, decidimos divulgar o evento com apenas dois dias de antecedência, no dia 17 de julho. A página do Facebook da MMNSP publicou um banner que chamava para a oficina, com o link para um formulário que explicava a proposta e solicitava a inscrição das participantes. Em menos de 2 horas, 31 mulheres estavam inscritas. Decidimos fechar a possibilidade de inscrição, pedindo que as interessadas na oficina enviassem um email, solicitando serem convidadas para oficinas futuras. Das 31 inscritas, 20, exatamente, participaram do encontro.

Abaixo, o convite divulgado no formulário: 
Narrar nossas memórias, ancestralidade e táticas de existência:
oficina de escrita autobiográfica para mulheres negras

VOCÊ RECEBERÁ UM E-MAIL QUANDO A INSCRIÇÃO FOR CONFIRMADA!

A oficina pretende incentivar mulheres negras a acessar e expressar suas memórias por meio da escrita, além de refletir sobre sua ancestralidade e aprimorar o estilo narrativo.

Conteúdo programático:

Escrevivência das mulheres negras, autobiografia, escrita de si

Memória e ancestralidade

Táticas cotidianas de existência

Com Bianca Santana, autora do livro "Quando me descobri negra" e colunista da revista Cult. Doutoranda em Ciência de Informação na Escola de Comunicação e Artes da Universidade de São Paulo (ECA-USP), mestra em Educação também pela USP e jornalista formada pela Faculdade Cásper Líbero, onde foi professora.

Dia 19 de julho de 2017, das 19 às 22h30

Oficina gratuita

20 vagas

Espaço Cult: r. Aspicuelta, 99, Vila Madalena, São Paulo - SP

NÃO HÁ PRÉ-REQUISITOS, TODAS AS MULHERES, EM QUALQUER NÍVEL DE ESCRITA, SÃO BEM-VINDAS COM SEUS SABERES

Contexto:

Em condições sociais, econômicas e políticas tão desfavoráveis, nós, mulheres negras, inventamos táticas e soluções colaborativas para a manutenção de nossas vidas e nossas comunidades. Nas cidades, quilombos, universidades, ações cotidianas de sabotagem e recusa, no candomblé, no samba, forjamos soluções coletivas para nossos problemas. Como registrava o manifesto da Marcha das Mulheres Negras 2015, cujo lema era Contra o racismo e a violência e pelo Bem viver: "Inspiradas em nossa ancestralidade somos portadoras de um legado que afirma um novo pacto civilizatório. (...) A sabedoria milenar que herdamos de nossas ancestrais se traduz na concepção do Bem Viver, que funda e constitui as novas concepções de gestão do coletivo e do individual; da natureza, política e da cultura, que estabelecem sentido e valor à nossa existência, calcados na utopia de viver e construir o mundo de todas(os) e para todas(os). Na condição de protagonistas oferecemos ao Estado e à sociedade brasileiros nossas experiências como forma de construirmos coletivamente uma outra dinâmica de vida e ação política, que só é possível por meio da superação do racismo, do sexismo e de todas as formas de discriminação, responsáveis pela negação da humanidade de mulheres e homens negros."

A partir dessas premissas, estou fazendo uma pesquisa de doutorado em Ciência da Informação, na USP, com o título: "Mulheres negras e o comum: memória, redes sociais e táticas cotidianas", sob orientação do professor Marco Antonio de Almeida. 
Como método, ofereço esta oficina de escrita, nos moldes que tenho experimentado há alguns anos, como possibilidade de expressão e autoconhecimento de mulheres. E peço para utilizar os textos produzidos pelas participantes, de forma anônima, no meu trabalho. Os textos serão analisados à luz de um referencial bibliográfico sobre mulheres negras, escrita de si, bem viver, comum, filosofia ubuntu, memória, táticas e redes sociais. Como não poderia deixar de ser, o resultado da pesquisa será divulgado para as participantes depois de sua conclusão.

No dia 18, enviei um email de confirmação para as 31 inscritas:

Bom dia mulheres amadas,

Vocês foram as primeiras a se inscrever para a oficina de escrita Narrar nossas memórias, ancestralidade e táticas de existência.

Muito obrigada pelo interesse de vocês.

Vai ser uma alegria estarmos juntas!

Começaremos às $19 \mathrm{~h}$, pontualmente. Então, se puderem, cheguem um pouco antes pra gente papear:)

É amanhã, 19 de julho, no Espaço Cult, que fica na rua Aspicuelta, 99, na Vila Madalena.

Caso alguém tenha algum problema e não possa vir, me avise, por favor. A procura foi grande e tentarei chamar outra mulher caso alguma de vocês não venha.

Vou providenciar papel e caneta, mas se alguém tiver o material do coração, traga.

Qualquer dúvida, pode me escrever neste email ou no WhatsApp (9xxxxxxx).

Não vejo a hora de encontrá-las!

beijo em cada uma,

Bianca

PS: Reproduzo aqui as informações todas sobre a oficina (e aqui se repetiam todas as informações do formulário, incluindo o contexto da pesquisa de doutorado).

Antes da chegada das participantes, organizei a sala em um círculo. No centro, espalhei 42 livros escritos por mulheres negras, um tecido africano estampado e um vaso de flores. A intenção, conforme premissa na educação popular, era criar um ambiente acolhedor àquelas mulheres que compartilhariam tanta intimidade. No link 
https://pt.wikiversity.org/wiki/Oficina_de_escrita_para_Mulheres_Negras está a lista dos livros espalhados no chão, além de alguns outros que citamos durante a oficina.

Às 19h, com mais da metade da turma completa, repassei o informe da Marcha, convidando para a concentração na Praça Roosevelt, às $17 \mathrm{~h}$ do dia 25 de julho, depois distribui as pequenas cadernetas que havia confeccionado para cada uma das participantes e demos início ao encontro.

Retomei que um dos objetivos da oficina era a produção de textos que eu pudesse analisar nesta tese. E antes de qualquer apresentação, a proposta de que todas fechassem os olhos, se conectassem à própria respiração e percebessem que estavam em um círculo de segurança, com outras mulheres negras, onde estavam protegidas pelo grupo. Ao abrir os olhos, cada uma deveria focar em um dos livros espalhados pelo chão, pegá-lo, sem abrir. Quando chegasse a vez de dizer o primeiro nome, a proposta era abrir o livro aleatoriamente, ler uma frase, e dizer se aquela frase se relacionava com quem ela era e por que. Depois de 17, das 18 mulheres que já haviam chegado, se sentirem conectadas e representadas pelas frases lidas, apresentei a dimensão coletiva da escrita. Cada uma daquelas autoras negras escreveu a partir da própria singularidade, é evidente, mas também da posição que ocupam no mundo, do lugar social de mulher negra, na maior parte dos casos, urbana. Não à toa nos identificávamos.

Depois da apresentação que já se conectou à parte teórica da oficina, li um trecho, traduzido por mim, de Grada Kilomba, professora da Universidade Livre de Berlim, artista multilinguagem, nascida em São Tomé e Príncipe, autora do livro Plantation Memories:

\author{
"Por que eu escrevo? \\ Porque eu preciso. \\ Porque minha voz, \\ em todos os seus dialetos, \\ foi silenciada por tempo demais. \\ (Jacob Sam-La Rose)
}

Este é um dos meus poemas preferidos. Eu o li centenas de vezes, de novo e de novo. E cada vez que o leio, parece que toda a minha história está contida nele. As cinco pequenas linhas nos lembram, de forma bastante engenhosa, uma longa história de silêncio imposto. Uma história de vozes torturadas, linguagens disruptivas, idiomas impostos, discursos interrompidos e os muitos lugares onde nunca pudemos estar para falar com nossas próprias vozes. Tudo isso parece escrito nele. Ao mesmo tempo, não é somente um poema sobre as contínuas perdas causadas pelo colonialismo. É também um poema sobre 
resistência, sobre a fome coletiva por nossas vozes, escrita e a recuperação de nossa história escondida. É por isso que gosto tanto dele.

A ideia de que é necessário escrever, quase como uma obrigação moral, encarna a crença de que a história pode "ser interrompida, apropriada e transformada por meio de práticas artísticas e literárias" (hooks, 1990, p. 152). Escrever este livro tem sido uma forma de transformação, porque aqui, eu não sou a 'Outra', mas eu mesma, não o objeto, mas o sujeito, sou eu quem descreve a minha própria história, não sou descrita. A escrita emerge, portanto, como um ato político (KILOMBA, 2008, p. 10).

Mostrei também a imagem da Escrava Anastácia, silenciada por uma máscara de tortura, que Grada Kilomba coloca no primeiro capítulo do livro, chamado "A Máscara". Quantas máscaras não silenciam, ainda hoje, as mulheres negras? Mas a máscara que silenciou Anastácia de forma tão violenta, absurda e degradante, não a impediu de falar. Quase 400 anos depois, a imagem de Anastácia roda o mundo denunciando os absurdos da escravidão. Apesar de todo o silêncio imposto das mais variadas formas, as mulheres negras realizam seus projetos de maneira sublime, como sempre nos lembra Jurema Werneck, em seus textos e intervenções orais. Ao olhar a máscara, fica evidente o absurdo, mas podemos nos conectar com a potência que foi, e ainda é, Anastácia.

Neste momento, as participantes compartilharam informações sobre a própria escrita: três tinham livros publicado, uma era autora de blog, outra de uma tese de doutorado, outra de artigo científico, muitas de textos no Facebook. Mas todas escreviam, mesmo que com pouca frequência e sem publicar.

Retomei os conteúdos que trabalharíamos na oficina: memória e ancestralidade, táticas do cotidiano e narrativas. Convidei para o primeiro exercício:

"Muitas vezes as lembranças da infância são mais presentes que as recentes. Vamos começar da infância, então. Lerei trechos de duas autoras que podem nos inspirar. São trechos curtos. Pílulas. Convites para que vocês mergulhem nas obras de escritoras negras ao saírem daqui". Concentradas, as 20 mulheres, no grupo já completo, ouviram o trecho de Geni Guimarães e o poema de Tula Pilar.

Minha mãe sentava-se numa cadeira, tirava o avental e eu ia, colocava-me entre suas pernas, enfiava as mãos no decote do seu vestido, arrancava dele os seios e mamava em pé.

Ela aproveitava o tempo, catando piolhos da minha cabeça ou trançandome os cabelos. Conversávamos às vezes:

Mãe, a senhora gosta de mim?

Ué, claro que gosto, filha. 
Que tamanho? - perguntava eu.

Ela, então, soltava minha cabeça, estendia os braços e respondia, sorrindo:

Assim.

Eu voltava ao peito, fechava os olhos e mamava feliz.

Era o tanto certo do amor que precisava, porque eu nunca podia imaginar um amor além da extensão dos seus braços.

Outras vezes, no meio da mamada, eu parava e começava:

Cadê o toicinho daqui?

$\mathrm{O}$ gato comeu.

Cadê o gato?

Foi caçar rato.

Cadê o rato?

Foi no mato.

Cadê o mato?

O fogo queimou.

Cadê o fogo?

A água apagou.

(GUIMAR ÃES, 2001, p. 16)

A maior parte das mulheres conhecia a quadrinha registrada por Geni Guimarães neste diálogo.

Caminho pela cidade

Caminho pelo mundo

Buscando meus desejos

Estive aqui

Estive lá

Estou junto de mim

Volto na infância

Onde os pés libertaram-me

Pelos campos de terra vermelha de Minas Gerais

Corri para brincar de pique-esconde

Pular corda, amarelinha

— Joga bola!

— Olha a pipa no céu junto com arco-íris

- Choveu!

A água da chuva na enxurrada

Nossa roupa cheia de barro

- Xiiii! A mãe vai bater na gente

- Vamos lavar na cachoeira

— Não! Lava em uma lagoa!

- Na água do rio

- Bate os pés! Lava rápido senão afunda!

— Está de noite

- Vamos para casa

- A mãe via chegar!

— Tia, acende a lamparina

- Machucou o pé de novo, menina!

Pés com eternas marcas de infância

Dormem para descansar

Acordam cedo para trabalhar

Caminham para o centro da cidade 
Os pés me levam para onde quero ir...

Para onde posso sonhar!

(PILAR, 2013, p. 116-117)

Depois de ouvir as narrativas, as participantes foram convidadas a fechar os olhos mais uma vez, respirar, ir a um lugar de conforto pela meditação. Para se encontrar com a menina que foi, em qualquer momento da infância. Que idade tinha? O que ela gostaria de contar do presente dela, passado da mulher de hoje, que agora é memória?

Cada uma das participantes escreveu. Depois, em círculo, pedi a cada uma que lesse em voz alta. Durante a leitura, pedi para, quem topasse contribuir com esta tese, fotografasse o próprio texto com o meu celular. Todas as participantes fotografaram o texto antes de passar para a seguinte, em círculo. Antes do final da leitura, eu tinha o registro fotográfico de cada um dos textos. Muitas mulheres se emocionaram durante a leitura, choraram e foram acolhidas por toques, gestos e sorrisos das que estavam perto.

Depois da leitura, provoquei: "Alguém pode se perguntar: mas foi isso mesmo que aconteceu?" Todas riram. Brinquei que elas podiam ter lembrado de tudo exatamente como foi, e ainda assim não ter sido exatamente aquilo. Ou das que não lembravam a história toda e ficavam tentadas e inventar. Nesta deixa, li Conceição Evaristo:

\begin{abstract}
Invento, sem o menor pudor. Portanto, estas histórias não são totalmente minhas, mas quase que me pertencem, na medida em que, às vezes, se (con)fundem com a minha cabeça. Invento? Sim, invento sem o menor pudor. Então, as histórias não são inventadas? Mesmo as reais, quando são contadas. Desafio alguém a relatar fielmente algo que aconteceu. Entre o acontecimento e a narração do fato, alguma coisa se perde e por isso se acrescenta. O real vivido fica comprometido. E, quando se escreve, o comprometimento (ou o não comprometimento) entre o vivido e o escrito aprofunda mais o fosso. Entretanto, afirmo que , ao registrar estas histórias, contínuo no premeditado ato de traçar uma escrevivência (EVARISTO, 2016, p. 7).
\end{abstract}

A proposta da oficina, portanto, é de registrar "escrevivências". Sabendo que os possíveis exageros e omissões também dizem sobre cada uma delas, e de suas histórias de vida. Neste momento, falei sobre Ecléa Bosi, e a visão de que a memória é um trabalho, no presente. E sobre Jeanne Marie Gagnebin, e a possibilidade de elaborar traumas e vivências a partir da narração. Contar, portanto, cura. E a escrita apresenta a possibilidade de registrar, mesmo que como ficção, muitas das histórias que não foram registradas. 
Já no primeiro exercício, muitas mulheres tinham escrito sobre a relação com o cabelo crespo. Não à toa, é um tema presente na escrita de mulheres negras. Li três trechos sobre o cabelo, de bell hooks, Chimamanda Adichie e Marli Aguiar:

Nas manhãs de sábado, nos reuníamos na cozinha para arrumar o cabelo, quer dizer, para alisar os nossos cabelos. Os cheiros de óleo e cabelo queimado misturavam-se com os aromas dos nossos corpos acabados de tomar banho e o perfume do peixe frito.

Não íamos ao salão de beleza. Minha mãe arrumava os nossos cabelos. Seis filhas: não havia a possibilidade de pagar cabeleireira. Naqueles dias, esse processo de alisar o cabelo das mulheres negras com pente quente (inventado por Madame C. J. Waler) não estava associado na minha mente ao esforço de parecermos brancas, de colocar em prática os padrões de beleza estabelecidos pela supremacia branca. Estava associado somente ao rito de iniciação de minha condição de mulher. Chegar a esse ponto de poder alisar o cabelo era deixar de ser percebida como menina (a qual o cabelo podia estar lindamente penteado e trançado) para ser quase uma mulher. Esse momento de transição era o que eu e minhas irmãs ansiávamos (hooks, 2005).

Mas Ifemelu não gostava de ter que ir a Trenton para trançar o cabelo.Não era surpreendente que não houvesse um salão especializado em Prince-ton - os poucos negros que ela vira ali tinham a pele tão clara e o cabelo tão liso que era difícil imaginá-los usando tranças -, mas, enquanto esperava o trem na Princeton Junction, numa tarde incandescente de calor, Ifemelu se perguntou por que não havia um lugar ali onde pudesse fazer suas tranças.

(...)

"Oi!", disse ela. Todas se viraram para olhá-la, mas apenas uma, que tinha de ser a Mariama que dava nome ao salão, disse: "Oi. Seja bem-vinda". "Eu queria trançar o cabelo." "Que tipo de trança você quer?" Ifemelu disse que queria uma trança torcida média e perguntou quanto era. "Duzentos", disse Mariama. "Paguei cento e sessenta mês passado". Ela havia trançado os cabelos pela última vez fazia três meses. Mariama não disse nada durante algum tempo, voltando os olhos para o cabelo que estava trançando.

"Então, cento e sessenta?", perguntou Ifemelu. Mariama deu de ombros e sorriu. "Tudo bem, mas você tem de voltar aqui da próxima vez. Sente. Espere pela Aisha. Ela vai terminar logo (...)

Ifemelu sentou perto da porta; o ventilador sobre a mesa riscada estava ligado no máximo, mas fazia pouca diferença no salão abafado. Ao lado do ventilador havia pentes, pacotes com apliques de cabelo, revistas repletas de páginas soltas e pilhas de dvds. Havia uma vassoura encostada num canto, ao lado da máquina de doces e do secador enferrujado que não era usado havia cem anos. Na tela da televisão, um pai batia em duas crianças, socos duros que atingiam o ar acima da cabeça das pessoas no salão (ADICHIE, Chimamanda, 2014, p. 10-17). 
Nossa mãe sempre nos dizia, quando criança e até pouco tempo antes de sua partida: 'seu cabelo é bonito e bom'. Imagino que ela não tinha, naquele momento, a dimensão do poder de suas palavras, e o quanto elas criavam identidade e resistência em nós. Quando criança ela gostava de nos pentear, massagear e acariciar nossos couros cabeludos e fazer tranças. Muitas crianças, muitos crespos, muito amor, também era necessário um pouco de paciência (AGUIAR, 2016, p. 23).

Depois das leituras, fiz a proposta do segundo exercício: "Há uma cena bem emblemática que mostre sua relação/ trauma/ revisão em relação ao cabelo? Lembre de uma cena, um causo e narre, conte a história." Em cerca de quinze minutos os textos foram escritos. E então tivemos uma nova rodada de leituras, em que as mulheres compartilharam, em voz alta suas narrativas. Muitas se emocionaram, interromperam a leitura pelo choro antes de conseguirem retomar. Presenciei muito apoio mútuo pelo toque de mãos e olhares acolhedores. Todas chegaram ao final da leitura. E toparam fotografar os próprios escritos para que eu pudesse analisar neste trabalho.

Em seguida, apresentei brevemente a noção de escrita de si que Margareth Rago traz de Foucault, com base nos fragmentos abaixo:

\begin{abstract}
A ' escrita de si' é entendida como um cuidado de si e também como abertura para o outro, como trabalho sobre o próprio eu em um contexto relacional (...). Trata-se, antes, de um trabalho de construção subjetiva na experiência da escrita, em que se abre a possibilidade de devir, de ser outro do que se é, escapando das formas biopolíticas de produção do indivíduo.

(...)

Trata-se de assumir o controle da própria vida, tornar-se sujeito de si mesmo pelo trabalho de reinvenção da subjetividade possibilitado pela 'escrita de si'. Trata-se de tornar-se autor do próprio script a partir de uma relação específica do indivíduo consigo mesmo, o que supõe ainda a prática política da parresia (RAGO, 2016, p. 52).
\end{abstract}

Narrar as próprias experiências seria, portanto, uma possibilidade de construção ou reinvenção subjetiva. Muitas delas, conectadas às mulheres negras que vieram antes, à ancestralidade. Se as mulheres negras são a base da pirâmide social brasileira, e as condições de vida são tão precárias, fica evidente que temos muitas táticas de existência. Propus a leitura de dois trechos de Carolina Maria de Jesus e outro da cronista Cidinha da Silva para refletirmos sobre tais táticas:

Mandei-lhe um bilhete assim: 'Dona Ida peço-te pode me arranjar um pouco de gordura, para eu fazer uma sopa para os meninos. Hoje choveu e eu não pude ir catar papel. Agradeço. Carolina (JESUS, 2006, p. 27). 
... Fiz a janta. E dei jantar as crianças. A Rosalina surgiu. Veio buscar um pouco de feijão. Eu dei (JESUS, 2006, p. 134).

\begin{abstract}
Mulheres negras, todas negras, dominam o mercado de comida de rua durante a festa. Tradição herdada das pretas de ganho do século XIX, das baianas do acarajé e outros quitutes do século XX para cá. Herança também de diversas impossibilidades consolidadas que as leva a desenvolver funções laborais nas quais possam manter os filhos por perto. Uma imagem de duas crianças encolhidas dividindo uma caixa de isopor como cama exemplifica a situação de mulheres que não têm com quem deixar os filhos enquanto trabalham.

Elas despendem horas e horas cozinhando junto com outras mulheres em casa. Previamente pesquisam preços para comprar ingredientes em grande quantidade, feijão, carnes, farinhas, pratos, copos e talheres de plástico. Catam feijão, picam carne, deixam de molho, escaldam, temperam, cozinham.

Preparam fogareiros, recipientes plásticos com tampas, imensas colheres de pau, panelas e os transportam em inacreditáveis motocas, até carrinhos de mão, para quem mora mais próximo do centro. Ônibus, vans, caronas de amigos ou parentes, aos quais se paga uma cerveja. Carros próprios, muitas vezes recolhidos pela fiscalização urbana por falta de condições para circular com segurança pelas vias públicas (SILVA, C., 2016, p. 29$30)$.
\end{abstract}

Ao ouvir, de que táticas cada uma daquelas mulheres lembrava? Tanto criadas e experimentadas por elas, como pelas mães, avós e outras mulheres? A proposta do terceiro e último exercício da oficina foi de escrever um causo que mostrasse como se viraram essas mulheres em alguma situação difícil. Mais 10 ou 15 minutos para o exercício, e outra rodada de leitura partilhada dos textos de cada uma. Mais uma vez, todas fotografaram seus textos para que eu os pudesse analisar.

Havia muita cumplicidade já entre as mulheres, que se mostravam animadas a continuar um diálogo umas com as outras ao término do encontro. Por iniciativa de uma participante, passaram uma lista para que escrevessem o número de telefone para a criação de um grupo de WhatsApp. A ideia era continuar a dialogar sobre a escrita e uma apoiar o processo de lembrar de escrever da outra.

Para encerrar o encontro, pedi que cada uma dissesse uma palavra de como havia sido a experiência. Agradeci a colaboração para esta pesquisa. E me coloquei à disposição para qualquer conversa posterior.

Segundo as participantes, a oficina foi: 
Liberdade. Carinho. Descoberta. Memória. Maravilhosa. Laços. Coletividade. Possibilidade. Emoção. Forte. Desabrochar. Redescobrir. Ubuntu. Paz. Conexão. Impulso. Resistência. 


\section{ANEXO 4: Fragmentos dos textos produzidos em oficina de escrita para mulheres negras}

Era noite, tinha viola. A luz era amarela, o céu era o mais estrelado que eu já tinha visto! No terreiro do meu padrinho e da minha madrinha acontecia um baile e eu que tinha lá pelos meus 8 anos dançava, dançava muito mesmo, eu gostava era de forró arrasta-pé.

$* * *$

Quando criança, ouve uma fase em que minha mãe não podia trabalhar, viúva e com três filhos pequenos ela nos fez sobreviver: pegava os restos de feira, tirava as partes ruins e fazia um refogado de legumes. Comíamos feijão com farinha e bolinho de chuva sem ovos no café da manhã. Hoje eu não tenho medo da vida, pois, aconteça o que acontecer, eu sei que eu saberei sobreviver.

$$
* * *
$$

Fiz das tripas coração para pagar uma faculdade de administração de empresas e lá estava eu! Às vésperas de ser a primeira a ter um curso universitário na família. Minha mãe trabalhou o dobro e comemos miojo muitas vezes para que este sonho se realizasse. Mas depois da perda do trabalho da minha mãe já ficou mais difícil pagar a faculdade, mas não desisti. Cheguei até o último semestre, endividada, mas cheguei. Não me formei.

A dona da faculdade, branca e com cabelo tingido de amarelo me disse: você veio pedir acordo? Você não tem dinheiro e veio negociar o que aqui?

E lá se foi meu sonho de pegar o diploma. Naquele dia saí de casa e disse pra mim mesma: não vou chorar, vou voltar aqui um dia com direito a tapete vermelho.

$$
* * *
$$

Tivemos que sair da casa, eu e minha filha. Era confortável financeiramente, porém insustentável psicologicamente.

Saímos só com as roupas para uma casa de quarto e cozinha. Arranjei um colchão de solteiro emprestado e um isopor para guardar o frango assado.

Nas Casas Bahia, depois de uma semana morando naquela casa, consegui comprar um fogão no carnê. Quando o fogão chegou, senti uma felicidade que há tempos não sentia. Na semana seguinte, por sorte, minha prima me vendeu a geladeira de quase 2 mil por 300, parcelado em 3 vezes. O essencial em poucas semanas consegui. $\mathrm{O}$ guarda-roupas era um remendo de cabos de vassoura.

$$
* * *
$$

Esses dias, lá em casa, uma das raras vezes que converso com a mãe, perguntei: "mãe, aonde foi que a vó inventou o cubre?" Deixa eu dizer, é uma comida que eu saiba foi criada e só existe na família Sabino, minha família por parte de mãe.

Bom, depois de minha pergunta, eu e minha mãe começamos a pensar e tentar encontrar uma explicação, cheguei até a pensar que minha vó, sendo a mulher que sempre foi, óbvio que inventava coisas só por inventar. Enquanto o famoso cubre estava no fogo, quase que ao mesmo tempo, mãe e eu dizíamos enquanto o óbvio chegava em nossas mentes: "Ué, cubre é fácil de fazer, basicamente só o fubá, o ovo, um tiquinho de 
sal e açúcar, uma massa de panqueca melhorada pelos Sabinos, foi feita mesmo pra encher a barriga dos 10 filhos. E dona Maria sempre soube o que inventar e até mesmo sem gostar de cozinhar até hoje o cubre aparece nos pratos lá de casa, fazendo a gente de barriga cheia se lembrar da vó, da mãe, da saudade."

$$
* * *
$$

Nos mudamos, casa nova, minha avó logo fez um fogãozinho à lenha no quintal para cozinhar o feijão a fim de economizar o gás, muito caro.

Um dia minha mãe fez uma massa de bolo, quando foi assar no forno do fogão à gás descobriu que havia acabado. Para nossa surpresa, ela pegou uma tampa de panela e cobriu a assadeira de bolo e a mesma colocou no fogão a lenha de minha avó.

O bolo ficou assado como se tivesse forno normal, mas era a sabedoria de minha mãe, sempre nos surpreendendo e nos fazendo feliz com seus sabores de comer.

$$
* * *
$$

As crianças todas da rua tínhamos medo da Anastásia. Era escura, suja, meio bêbada, meio louca, falava sozinha, dormia nas ruas e surgia do nada.

Teve aquele inverno que fazia frio, muito frio em Bauru. Não é cidade de frio, e ninguém estava preparado, muito menos a Anastácia.

Quando minha mãe chegou da missa, a Anastácia estava dormindo em frente ao bar do meu pai, tentando se aquecer como podia. A mãe entrou, a mãe rezou e saiu. Voltou com a Anastácia: "temos uma hóspede neste inverno."

$$
* * *
$$

Um relacionamento abusivo. Ela decidiu dar um basta naquela relação que quase a levou à morte. Ele levou embora o fogão, o botijão de gás e a comida do armário. Só deixou a geladeira vazia. Ela, desempregada e com a filha de 5 anos, levou a criança para a casa de amigas, afinal, a menina não podia ficar sem comer. Pediu dinheiro emprestado e com ele fez mouses para vender na rua.

No final de semana conseguiu trazer sua filha de volta para casa.

Ela decidiu que seria um novo começo. Não seria novidade para ela. ***

A separação estava posta depois de 15 dias na casa da minha tia, minha mãe, depois de muita procura, encontrou uma casa. Era bem pequena.

Em meio a essa situação de recomeço só tínhamos a casa alugada, já que nossas coisas estavam todas com meu pai. Foi um verdadeiro mutirão. Cada parente nosso que chegava para ver nossa conquista ajudava com o que tinha. Tia Luiza com as panelas, minha prima com mesa e cadeira minha tia Maria com os pratos. Hoje em dia, depois dessa fase, até hoje temos muito carinho.

$$
* * *
$$

Dia esperado de pagamento. O banco só no centro da cidade. Passagem contada para uma pessoa. Uma pessoa com dois filhos pequenos. Uma menina e um menino. $\mathrm{O}$ sol esquentava o asfalto, fazia os pés das crianças em tênis conga suarem. O primeiro ônibus passa lotado. A mãe ansiosa segurava os filhos pelas mãos. Segundo ônibus, cheio, mas conseguiram que coubessem mais de dez pessoas. A primeira criança mais magrinha passa por debaixo da catraca sem dificuldades. Já o menino maior e robusto ficou vermelho de não conseguir passar o quadril. 
O ônibus cheio, o cobrador dizendo pra mãe se virar. A mãe suava, suava. Eis que a vizinha na porta que quase não fechava grita:

- O comadre, eu tenho um troco aqui. ***

Eu tava no bar com meus amigos cantores de ópera, como eu. Não há mal nisso, poxa.

Mas ele sempre achava mal.

Bom, respondi:

"Oi, gatinho, tô em casa indo dormir. Amanhã falamos, beijo, te amo, tá?" Guardei o celular e ri me sentindo a bandidona.

Rafael Oherdan, nome composto do meu primeiro e único namorado. Sete anos estivemos juntos. Nós últimos 4 era só briga, ele era lindamente ciumento.

Sempre queria saber onde eu estava, mas detestava falar por telefone.

$\mathrm{Eu}$, que já andava bem amuada na relação, resolvi dar de louca igual ele tanto fez comigo, um dia, um diazinho não faz mal.

“W(...), onde você tá?", ele me mandou de novo no WhatsApp.

$* * *$

Meu pai era minha pessoa preferida no mundo. Era também a pessoa preferida da minha prima (ela era filha de pai desconhecido). eu odiava emprestar meu pai pra ela, mas minha prima era tão pequena e precisava do colo do meu bem, então me conformei e emprestei.

$* * *$

Soube desse fato depois de crescida. Minha avó materna, vó Rosa, sempre me passou uma imagem ríspida e fria. Sem muitos carinhos e manhas. Porém meu pai me contou um fato que pessoalmente encaro como um dos mais humanos até hoje.

Dentre alguns e algumas, tenho minha tia Maria Rosa, a qual se casou duas vezes na vida.

Hoje ela carrega a maternidade de minha prima Cristiane e Eduardo. Contudo, em sua antiga juventude e primeiro casamento, teve um filho, Rafael, cujo pai, alcoólatra e agressor abandonara. Na época, o fato de ser mulher jovem solteira com filho era ainda mais inaceitável, desta forma minha avó Rosa assumiu a maternidade e criou como filho meu tio Rafael. $* * *$

$\mathrm{Na}$ Bahia, o que mais se comia era farinha, alimento farto na terra onde vim. Todos reservavam um tempo para fazer sua farinha na casa de farinha que ficava no centro da cidade. Para dar sustança e pra fome passar, de noite, às vezes comida não tinha Então o que se comia era café com farinha. Era o que minha mãe tinha pra me dar. Hoje em dia nem café eu tomo. Acho que gostava daquele café e daquela farinha. $* * *$

Ela estava sem o que comer, sem o que vestir. Meu pai veio até São Paulo e viu a sua memória. Sua irmã estava no barraco perto da estrada. Ela já não sabia o que fazer, bebia para esquecer. Sua filha era mãe e a mãe filha, e a minha arrimo de família.

Imediatamente minha mãe contou para mim que disse ao meu pai: tem que trazer pra cá, ela é sua irmã.

Eles tiraram a família da casa que eles construíram ao casar. Era uma das fontes de renda, Minha mãe fez meu pai arrumar tudo para que eles viessem. Lá no 25 de janeiro eles chegaram. Poucas coisas, quase cabiam debaixo do braço. 
Neuza e Camila começavam uma nova história. Ela morreu ao sair de casa. Agora fica Camila. Vá em paz, tia, a casa tá arrumada.

$* * *$

Meu penúltimo irmão foi o único que nasceu no hospital. Todos os outros 14 nasceram em casa com parteiras. Ele era muito fraquinho e quando tinha quatro meses ficou muito doente e eu via minha mãe preparar um mingau de fubá e colocar quase quente em um pano. Fazia um embrulho e colocava no peito do bebê. Era emplasto, para fazer soltar o catarro do peito dele que estava com pneumonia e foi curado em casa. Depois que a morte passa ela deixa impulso para viver.

$* * *$

Ela sentiu um pó branco com cheiro fétido entrar nas suas narinas. $\mathrm{Na}$ embalagem verde de lona com desenho de insetos. Está descrito mata piolhos, baratas e outros insetos.

Aquilo ficou na sua cabeça horas, quando lavou passou por outro processo, vendo seus cabelos caindo no chão. Quando olhou naquele espelho quebrado se viu menino.

$* * *$

Num dia chuvoso de novembro, a menina e sua mãe chegou na nova moradia Assustadas, com pouca força, descarregaram seus cacarecos.

Cohab Adventista, terra do Mano Brown.

Agora aquilo era pertencente de dona Ilda e Maria, mesmo sendo através de uma ocupação.

Enfrentaram muitas dificuldades, lá a menina teve seu primeiro beijo e viram aquele bairro desabrochar.

Saudades, Cohab Adventista.

$$
* * *
$$

Quando eu tinha por volta dos 13 anos era quase que obrigação alisar os cabelos. Era uma cerimônia. Minha irmã mais velha havia comprado um pente de ferro que esquentava no fogo. Nosso fogão era à lenha, então não dava para saber a temperatura do ferro. Somente quem tinha experiência sabia que ele estava bom para o alisamento. Eu fui alisar o meu sozinha, escondida, é claro, e o ferro estava muito quente e eu queimei uma mecha de cabelo bem na frente da cabeça. Foi horrível para eu frequentar a escola naqueles dias, eu precisava puxar um tanto de cabelo na testa para esconder a falha. A sociedade era cruel e as jovens negras precisavam estar de cabelos lisos para serem aceitas.

$* * *$

Finalmente chegou o dia. De repente me decidi. Por que eu não posso usar um cabelo que é meu? A partir desse questionamento a possibilidade de usar meu cabelo apareceu na minha frente, esse questionamento me deu certeza de que ser o que ele era me deu força.

Então, no salão especializado em cabelo afro acabou o fim da transição que levava um ano. Por que esperei tanto tempo? A cada mecha cortada a felicidade me transbordava e sentia que estava me libertando. Apenas sorria para o cabelo que descobria.

$* * *$

Minha mãe trança meus cabelos desde meus 8 meses de idade.

Recordo que por volta dos 5 ou 6 anos, os momentos de lavagem do meu cabelo eram geralmente semanal. Quem desfazia as tranças era eu. Normalmente era com xuxinhas coloridas. Ela amarrava uma na raiz do 
cabelo, trançava, e amarrava outra na ponta. Separava meu cabelo em várias partes, com xuxinhas maiores, eu sentava em uma almofada no chão, entre as pernas dela. Após a lavagem ela desembaraçava meu cabelo com um pente não muito apropriado, com dentes pequenos e finos. Eu lembro como doía. Quando eu saia do chuveiro com o cabelo molhado, ela passava o creme de pentear. Ficava lindo. Bem soltinho e definido. Lembro de como me sentia feliz nessa hora.

$$
* * *
$$

Entrei no salão e disse:

- Quero passar a máquina.

Maria me olhou assustada e disse:

— Tem certeza? Seu cabelo está lindo.

Afirmei que sim balançando a cabeça.

Meia hora depois saí do salão com a cabeça livre e leve.

$* * *$

Estava em Campinas e fui para Marília visitar meus pais. Eu me lembro que era um final de semana, na casa de minha avó, minha mãe disse: desse jeito não dá, você não pode ser jornalista com o cabelo assim!

Eu lembro que me levantar até a sala da minha avó, a sala que eu dancei a vida inteira ouvindo os discos de axé da Ivete Sangalo e até Adriana Calcanhoto.

Talvez aquela sala tenha me visto pela primeira vez triste, sem música. É que eu também chorava ou refletia com Adriana, o disco estava até riscado, mas naquele dia eu deitei no sofá amarelo com a capa de crochê e fechei os olhos.

Só queria entender: por que não?

$* * *$

Meu primeiro alisamento deve ter acontecido quando eu tinha uns 10, 11 anos e veio com uma promessa. Facilitava os cuidados, eu teria a raiz lisa e cachinhos nas pontas.

A partir daí, visitas semanais ao salão a cada 3 meses, um cheio horrível nas narinas. Não sei se era mais fácil, mas isso parecia mesmo melhor (dos cachinhos nas pontas ninguém nunca mais falou).

Foram anos me sentindo linda no começo da semana, mais ou menos no meio e feia no fim da mesma.

O tempo passou, eu parei de alisar.

Acordei hoje de manhã e sem nenhum ritual ele estava lindo. Pensei: como é forte o poder da mentira.

$* * *$

Chegamos no pai. O portão vinho velho enguiçou, mas conseguimos abrir. Fomos entrando e ele tava sentado na mesa redonda velha que tivemos na infância quando era casado com a mãe.

- E aí, painho, bença.

- Deus que abençoe.

— Pai, você já viu minha tatuagem?

- Aham, com ar de desprezo.

- O que achou? Perguntei com a mesma empolgação dos meus alunos de

7 anos, mesmo tendo 25 .

- Ridícula, em alto e bom som.

$\mathrm{Ri}$ até perder $\mathrm{o}$ ar.

— E eu de tranças, já me viu?

- Não! Tem foto? 
Mostrei no celular.

O pai é difícil se emocionar, mas a emoção dele chegou em mim, nos olhamos e ele disse:

— Ai ó, linda! Uma rainha! Negra! Minha filha! $* * *$

Todo domingo eu ia até o salão da dona Lia trançar o cabelo.

Até hoje quando eu vejo a Dona Lia eu me alegro toda, tenho amor.

O salão era pequeno, cabia duas cadeiras de cabeleireiro, a pia para lavar cabelo e uns banquinhos de madeira para quem ia esperar.

Ela era uma mulher evangélica e completamente mal humorada.

Tinha um filho com deficiência mental, e toda vez que ia lá ela falava que eu tinha que casar com o filho dela, pudera, eu era só uma criança, mas ficava com medo de dizer que não ia casar com ele não, tinha dó daquela situação.

Dona Lia, vendo que eu não aprovava a sua ideia, puxava meus cabelos e quando eu reclamava ela falava: mulher pra ficar bonita tem que sofrer.

$* * *$

Depois de muitos anos, neste ano, revi minha avó materna. Desde pequenas que não sentia seu amor e proteção de tão perto. Minha avó indígena de longos cabelos que agora estão levemente esbranquiçados.

Mãe de minha mãe, que não consegue mais andar e enxergar direito, me acalantou no colo e disse: como seu cabelo é gostoso e macio, tantos cachinhos.

$$
* * *
$$

A Maria ficou surpresa: "Raspar?! A gente corta curtinho." "Raspa, raspa tudo. Máquina". Ela raspou.

A Maria não conseguiu esconder o receio, mas também não escondi o orgulho. Mais de 20 anos depois, me libertei.

$$
* * *
$$

O cabelo era comprido, ela adora deixá-lo solto, mas a mãe reclamava ao pentear, pois era muito embaraçado.

Um dia, lá pelos 7 anos de idade da filha a mãe pediu para uma vizinha cortá-lo.

Peraí, vou dizer a cena: levou a menina a casa da vizinha que sentou-a num parquinho no quintal de casa. E zap. zap. Foi passando a tesoura sem dó. Quando acabou, pegou um espelho e mostrou à menina, que nada falou. Saiu dali e chorou sentida por dias. E falou para a mãe: nunca mais ninguém coloca a mão nos meus cabelos. Pois a partir desse dia ela sofreu muitos deboches na escola, entre os colegas do bairro todos diziam parecia um menino com aquele corte minúsculo. Imagine você andar na rua sentindo olhares direcionados para si, para sua cabeça, seu cabelo, foram dias, meses e anos assim. E pior, o cabelo nunca mais foi o mesmo. Até nome de neguinha de cabelo pixaim ela recebeu, foi mesmo muito triste, foi...

$$
* * *
$$

Estava com aquele canecalon já há muitos meses. Bem mais do que o recomendado. A cabeleireira não conseguia desembaraçar, mas não tinha jeito, minha mãe não tinha dinheiro para pagar antes.

Doía muito, e eu chorava. Não fazia sentido. Finalmente, não fez sentido. Pedi pra raspar. 
Estávamos tomando café da manhã na casa da minha tia. Era uma manhã ensolarada, bem gostosa... Conversa vai conversa vem, quando de repente o assunto era eu...

Minha mãe falava sobre nós e sobre a relação com meu pai, minha tia olha para mim e diz:

- O que tem feito com seu cabelo, Lu?

— Respondo: nada.

— Minha mãe: tem passado amaciante só para soltar.

- Minha tia comenta: tem que fazer uma escova nesse cabelo... Como é que vai arrumar um namorado? Já está mocinha, tem que se arrumar... $* * *$

Minha mãe mantinha o corte do meu cabelo bem curtinho porque era mais fácil de pentear e eu não sofria tanto.

Um certo dia fomos à uma escola onde meus pais fariam a minha matrícula. O diretor perguntou:

- É um menino? Como chama? Mesmo eu usando brincos e uma pequena presilha nos cabelos, ele me confundiu com um menino.

Foi traumatizante! Nunca desejei tanto ter cabelo liso como naquele dia. $* * *$

Ela estava com várias trancinhas na cabeça, não conseguia nem contar todas. A mãe colocava tererês coloridos para deixar mais bonito.

Mas ao som da TV ligada e das panelas no fogão e com a irmã, veio a brincadeira de pegar uma toalha não muito grande nem muito pequena $\mathrm{e}$ encaixar na cabeça, à vezes prendendo atrás da cabeça, outras com bico de pato, deixando solto, para que aquele cabelo liso, feito de toalha, voasse, desse a sensação de liberdade daquela aparência. Ela corria pela casa, desviando dos móveis naquele espaço pequeno, mas ela corria feliz, realizada, com aquele cabelo bom e bonito.

$* * *$

No salão, fui fazer as unhas e sondar como a cabeleireira lidava com cabelos crespos.

Perguntei por uma hidratação que definia cachos. Ela falou maravilhas da manteiga de karité. Aceitei fazer a hidratação, fiz todo o procedimento de lavar meus cabelos com xampu e depois aplicar o creme por 15 minutos. Fiquei esperando para enxaguar os cabelos. Ela o fez, até aí normal, tentar desembaraçar meus cabelos com um pente fino. Não deixei, mas ela não parava de pentear. Como não podia escovar, pois eu queria os cachos, começou a passar as...

$* * *$

Era aniversário da Gabi, tinha que estar linda. Tomei banho, lavei o cabelo, passei óleo, esperei secar naturalmente. Aqueci o pente de alisar no fogão, passei por todo o cabelo. Depois passei a chapinha. Pronto. Estava bem e lindamente liso. Cheguei no bar para comemorar, me sentindo linda. Rindo e falante por um momento, chacoalhando o cabelo com a mão, o casal branco atrás de mim, reparando a cena, riu. Ouvi eles falando: acha que tem cabelo liso.

$* * *$

Meu pai faleceu quando eu tinha 14 anos. E até os 14, o único a "aparar" meus cabelos longos era ele. Eu tinha muito cabelo e acho que meu rosto se perdia neles, gostava de rabo de cavalo, de colocar as piranhas que ganhei com araras gigantes e gotinhas coloridas, mas o que eu queria mesmo era a franja da Mara Maravilha. 
Mara era a minha favorita. O cabelo dela era preto, só não entendi porque não tinha paquita negra.

Por isso, minha franja reta igual à da Mara, "só que não". Meu pai cortava e dois minutos depois era franja pra todo lado, menos na testa. Fiquei por um bom tempo com dois chifrinhos, nada parecidos com a franja da Mara. Após a morte do meu pai demorei fazer um corte no cabelo, até que aos 20 resolvi vender o cabelo. Renasci! Meu cabelo nasceu outro. Já não era ondulado, os cachos chegaram e o curto agora é o que eu gosto. 


\title{
ANEXO 5: Autoras de Inovação Ancestral de Mulheres Negras: Táticas e Políticas do Cotidiano, com breve apresentação
}

\begin{abstract}
Alessandra Ribeiro
Doutora em urbanismo e historiadora pela PUC-Campinas. Estuda Matriz Africana: territórios, memória e representação. É gestora da Casa de Cultura Fazenda Roseira, Mestre da Comunidade Jongo Dito Ribeiro, coordenadora pedagógica e de pesquisa do CEPIMA e Mãe de Santo Umbandista.
\end{abstract}

\section{Ariane Cor}

Paulistana, designer, ilustradora, programadora e estudante de Ciências Sociais na FFLCH - USP. É co-fundadora do \#MinasProgramam (minasprogramam.com), onde desenvolve e coordena projetos que buscam envolver meninas e mulheres negras e periféricas com tecnologia.

\section{Bianca Santana}

Doutoranda em ciência da informação e mestra em educação pela Universidade de São Paulo. Pesquisa memória e a escrita de mulheres negras. Jornalista formada pela Faculdade Cásper Líbero, onde foi professora. Colunista da revista Cult. Autora de Quando me descobri negra.

\section{Beth Beli}

Percussionista e arte-educadora. Diretora e professora de percussão dos ritmos dos Orixás e Malinkes. Presidenta e regente do Bloco afro Ilú Obá De Min - educação, arte e cultura negra. Graduada em Ciências Sociais. Arte- educadora na instituição Arte Despertar.

\section{Carmen Faustino}

Mulher negra da periferia Sul de São Paulo. Poeta, escritora, arte-educadora e gestora cultural. Tem formação em letras e especialização em história da África e cultura afrobrasileira. Atua na cultura negra e periférica há 10 anos, desenvolvendo ações e projetos de valorização da literatura negra feminina e da cultura negra. É ativista e fortalecedora das questões raciais, sociais e de gênero. 


\section{Carolina Rocha}

De Xangô, educadora, escritora e militante. Mestre em história pela Universidade Federal Fluminense. Autora do livro: O Sabá do Sertão: feiticeiras, demônios e jesuítas no Piauí Colonial. Doutoranda em sociologia no Instituto de Estudos Sociais e Políticos (IESP) da UERJ, estudando conflitos religiosos da atualidade. Desenvolve oficinas em escolas públicas sobre racismo, cultura afro-brasileira e intolerância religiosa. Recentemente publicou suas poesias no livro Lâmina.

\section{Cleo Dias}

Estilista, fundadora da Casa Cleo Ateliê. Figurinista do bloco-afro Ilú Obá de Min e do bloco Zumbido. Foi gerente comercial por 20 anos, até decidir assumir seu ifá de desenhar, cortar e costurar, espalhando beleza no mundo.

\section{Dalva Regina Santos}

Gestora de políticas públicas, pesquisadora e produtora executiva. Mestra em sociologia pela Unicamp. Nascida e criada no Rio de Janeiro, por uma família branca, mas com ancestralidade baiana, negra. Desde 2009 mudou-se para São Paulo e Brasília onde atua no campo da cultura. Faz parte do grupo Ilú Obá de Min e sonha ser doula.

\section{Débora Marçal}

Bailarina e atriz, co-fundadora e intérprete pesquisadora da Capulanas Cia de Arte Negra e do Movimento Mercedes Baptista. Coreógrafa e figurinista do Instituto Umoja e coordenadora de dança e coreógrafa do bloco afro Ilú Inã. Graduada em licenciatura em dança. É proprietária, designer de joias e ourives da marca Preta Rainha. Coautora de diversos livros. Protagonizou junto com Léa Garcia o curta O dia de Jerusa, selecionado para o Festival de Cannes em 2014.

\section{Jackeline Aparecida Ferreira Romio}

Doutora e mestre em demografia pelo Instituto de Filosofia e Ciência Humanas da UNICAMP. Bacharel e licenciada em letras pela Faculdade de Filosofia, Letras e Ciências Humanas da USP. Desenvolve pesquisas interdisciplinares sobre a violência e a relação entre as opressões raciais, de gênero, sexo e de classe; escritora de artigos sobre os temas do feminicídio, epistemologias feministas, mortalidade feminina, saúde reprodutiva e sexual, e indicadores sociais da violência. CV: http://lattes.cnpq.br/1765748820147754 


\section{Lara Dee}

Empreendedora Social, socióloga, fundadora e diretora do Instituto Beleza \& Cidadania, onde criou o Programa de Gestão Inovadora, que consiste no resgate da autoestima, melhoria da qualidade de vida, de geração de emprego e renda, utilizando como ferramenta a beleza para o empoderamento das mulheres. Fundadora da O.S. Bela Beleza Belíssima, onde desenvolveu o Projeto TransVidro. Tornou-se membro da Ashoka em 2005, foi membro do Comitê do Programa Acolher da Natura e há seis anos viaja pelo Brasil.

\section{Lívia Milena da Silva}

Mulher negra, nordestina - natural de Pindobaçu-Bahia - e moradora da Zona Leste paulistana. Assistente Social cursando especialização em direitos humanos, diversidade e violência na UFABC. Autora do livro O Processo de Reinserção Familiar de Crianças e Adolescentes (2017). Atuou como educadora social na política de enfrentamento à violência contra as mulheres no programa Casa Abrigo Regional Grande ABC. Atualmente trabalha como assistente social em serviço de acolhimento institucional para crianças e adolescentes no território de Cidade Tiradentes.

\section{Luciana Bento}

Mulher-negra-mãe em tempo integral. Defensora de uma escrita uterina e materna, é autora do blog A mãe preta, no qual fala sobre maternância, negritude e literatura. Pesquisadora de literatura com protagonismo negro, amante das palavras e do mundo dos livros, também fala sobre literatura nas redes sociais pelo projeto Quilombo Literário. Socióloga por formação, atua também como editora, preparadora de texto, consultora literária, mediadora de leitura, livreira e design instrucional para EAD. Realiza oficinas de formação de leitores e de mediação de leitura para educadores e famílias. Colunista do Portal Lunetas sobre múltiplas infâncias e do site literário Leitor Cabuloso. Podcaster no projeto O podcast é delas.

\section{Luciana Reis}

Graduada em serviço social e pós graduada em gestão de projetos sociais e políticas públicas. Participa do coletivo As Carolinas e Firminas que promove encontros de mulheres negras para se fortalecer através da escrita. Trabalha com pessoas em situação de rua desenvolvendo trabalho de orientação, mediação e inserção dos usuários nos serviços 
de saúde e assistenciais. A primeira a se formar em uma família comandada por mulheres fortes. Mãe, tia e tia avó, continua na luta por uma vida melhor para dar dignidade à família.

\section{Luana Bayô}

Cantora, compositora e educadora. Formada em letras pelo Mackenzie, ministra aulas de português para alunos dos ensinos fundamental e médio do estado de São Paulo. Além disso, se dedica a seu trabalho autoral como cantora.

\section{Luana Vieira}

Mãe, nascida e criada na Zona Sul de São Paulo, militante, graduada em recursos humanos. Gestora executiva do projeto sócio-cultural Comunidade Pagode Na Disciplina Jardim Miriam. Atualmente, levantando discussões e temas voltado à falta de representatividade feminina em espaços culturais periféricos, sobretudo em rodas de samba.

\section{Lucia Makena}

Formada no magistério, depois em pedagogia, com pós-graduação. Lecionou em canteiro de obras, presídio feminino e em escolas públicas. Ministra cursos de formação para professores, crianças, grupo de mães, mulheres em situação de violência doméstica e comunidades de ocupação. Leciona no curso de pedagogia da FEDUC e faz a assessoria de imprensa da netinha Mc Soffia. Gosta de estudar, participar de marchas dos movimentos sociais, lutar contra as desigualdades e ouvir rap.

\section{Maitê Freitas}

Jornalista. Atriz. Poetisa. Produtora e assessora cultural. Pesquisadora das tradições afrobrasileiras. Idealizadora e coordenadora do projeto Samba Sampa, produtora executiva do projeto Empoderadas.

\section{Maria de Jesus}

Tem 63 anos de idade, uma filha, três netos biológicos e muitos de coração. É economista aposentada. Foi babá e empregada doméstica desde os cinco anos de idade, até passar em um concurso público para trabalhar no administrativo da Secretaria Estadual de Saúde e depois em bancos e empresas privadas. Graduou-se em economia, um curso majoritariamente branco e masculino, em 1979. É trabalhadora em centros kardecistas 
onde, além das práticas espirituais, participa dos preparativos e distribuição de alimentos para pessoas em situação de rua.

\section{Marli de Fátima Aguiar}

Leonina, educadora social, gestora ambiental, escritora e militante feminista. Formada em letras - português e espanhol pela Unifesp Guarulhos, pelo sistema de cotas, sim! Autora do livro de contos Tecendo Memórias e Histórias, produção artesanal e coletiva. Publicou recentemente poemas no Cadernos Negros. Atualmente trabalha com cooperativas de catadoras e catadores de materiais recicláveis. Participa de coletivos de mulheres negras. Realiza oficinas de escrita para mulheres negras como espaços de descoberta de si e das outras, espaço de cura e de reencontro ancestral através de seus escritos poéticos e literários.

\section{Miriam Nobre}

Agrônoma, realiza formação e investigação em economia feminista, economia solidária e agroecologia como parte da equipe da SOF - Sempreviva Organização Feminista. Militante da Marcha Mundial das Mulheres cujo secretariado internacional coordenou entre 2006 e 2013.

\section{Nega Duda}

Ducineia Cardoso, a Nega Duda, é referência do samba de roda baiano na capital paulista. Homenageada no carnaval paulista pelo bloco afro Ilú Obá de Min. Em São Paulo, criou o Samba de Roda Nega Duda, onde desenvolve o Ekán de Axé, e Tem Recôncavo em SP. O samba de roda traz referências do culto aos orixás e caboclos, à capoeira e à comida ancestral. Seus shows são uma celebração a uma importante tradição popular e cultural brasileira.

\section{Sandra Silva}

Caipira de Bauru, interior de São Paulo. Bacharela em relações internacionais pela UNESPFranca e mestra em relações internacionais pela UnB. Seus interesses sempre estiveram voltados para as construções políticas populares: autodeterminação, integração regional e parcerias estratégicas, latinoamericanidade, mulheres afrolatinas, panafricanismo, movimentos negros. Já trabalhou em diversos espaços das Américas e das Áfricas e atualmente é chefa de gabinete da deputada Erica Malunguinho, na Alesp. Seu pai costuma 
dizer que "a neguinha foi pra rua e nunca mais voltou". Ledo engano: ela volta para casa todos os dias, desde que saiu.

\section{Silvana Bahia}

É uma experimentadora, curiosa. Ao longo dos anos vem desenvolvendo trabalhos em áreas como tecnologia, inovação, comunicação, pesquisa, audiovisual e literatura. Mestre em cultura e territorialidades, graduada em jornalismo. Atualmente é diretora do Olabi, organização social focada em diversidade na produção de novas tecnologias, por onde coordena a PretaLab, iniciativa que visa estimular mulheres negras e indígenas nas tecnologias e inovação.

\section{Tula Pilar}

Coordenadora do Raizarte - coletivo de música, dança e poesia. Vendedora da revista OCAS - organização civil de ação social. Participante do Projeto Trecho 2.8 - criação e pesquisa em fotografia.

\section{Vanessa Nascimento}

Graduada em letras, coordenadora de projetos sociais e membro da Uneafro Brasil. Mãe de Odara.

\section{Winnie Bueno}

Iyalorixá, bacharel em direito pela Universidade Federal de Pelotas. Mestranda em direito pela Universidade do Vale Rio dos Sinos na linha de pesquisa Sociedade, Novos Direitos e Transnacionalização. Discute temas voltados às questões raciais, gênero e sexualidades, direitos humanos, intolerância religiosa e pensamento feminista negro. Colabora junto aos movimentos sociais por meio de cursos, palestras e oficinas nas temáticas relacionadas às experiências e vivências de mulheres negras, sobretudo em uma perspectiva teórico-crítica voltada para a análise do direito e da justiça. 